Sérgio Pereira Andrade

\title{
QUANDO O PENSAMENTO VEM DANÇANDO, QUANDO A SOBERANIA TREME - evento por vir, democracia por vir, razão por vir.
}

\section{Tese de Doutorado}

Tese apresentada ao Programa de PósGraduação em Filosofia da PUC-Rio como requisito parcial para obtenção do título de Doutor em Filosofia.

Orientador: Prof. Paulo Cesar Duque Estrada 


\section{Quando o Pensamento Vem Dançando, Quando a} Soberania Treme - evento por vir, democracia por vir, razão por vir.

Tese apresentada como requisito parcial para obtenção do grau de Doutor pelo Programa de Pós-Graduação em Filosofia do Departamento de Filosofia do Centro de Teologia e Ciências Humanas da PUC-Rio. Aprovada pela Comissão Examinadora abaixo assinada

Prof. Paulo Cesar Duque Estrada

Orientador

Departamento de Filosofia - PUC-Rio

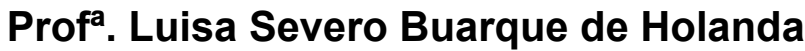

Departamento de Filosofia - PUC-Rio

Prof. Luiz Camillo Dolabella Osorio de Almeida

Departamento de Filosofia - PUC-Rio

Prof. Roberto Charles Feitosa de Oliveira Universidade Federal do Estado do Rio de Janeiro-UNIRIO

Profa. Alice Mara Serra

Universidade Federal de Minas Gerais-UFMG

Profa. Monah Winograd

Coordenadora Setorial de Pós-Graduação e Pesquisa do Centro de Teologia e Ciências Humanas - PUC-Rio

Rio de Janeiro, 09 de Setembro de 2016. 
Todos os direitos reservados. É proibida a reprodução total ou parcial do trabalho sem autorização da universidade, do autor e do orientador.

\section{Sérgio Pereira Andrade}

Artista e pesquisador em dança, performance e filosofia. Professor do Departamento de Arte Corporal da Escola de Educação Física e Desportos da Universidade Federal do Rio de Janeiro (DACEEFD/UFRJ). É Doutor em Filosofia pela Pontifícia Universidade Católica do Rio de Janeiro (PUC-Rio), Mestre em Filosofia pela PUCRio e Mestre em Artes Cênicas pela Universidade Federal da Bahia (UFBA). Graduou-se em Licenciatura em Dança pela Escola de Dança da UFBA.

Ficha Catalográfica

Andrade, Sérgio Pereira

Quando o pensamento vem dançando, quando a soberania treme: evento por vir, democracia por vir, razão por vir / Sérgio Pereira Andrade ; orientador: Paulo Cesar Duque Estrada. - 2016.

259 f. : il. color. ; $30 \mathrm{~cm}$

Tese (doutorado)-Pontifícia Universidade Católica do Rio de Janeiro, Departamento de Filosofia, 2016.

Inclui bibliografia

1. Filosofia - Teses. 2. Desconstrução. 3. Soberania. 4. Pensamento. 5. Dança. 6. Performance. I. Duque-Estrada, Paulo Cesar. II. Pontifícia Universidade Católica do Rio de Janeiro. Departamento de Filosofia. III. Título. 


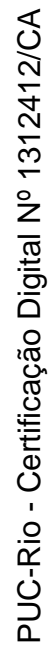

Para Lúcia Fernandes Lobato, que me encorajou a pensar a dança e a filosofia. 


\section{Agradecimentos}

À minha mãe, Raema, e ao meu pai, Sérgio, pelo amor e apoio incondicionais. Pela coragem que sempre emanaram em suas vidas e, assim, me encorajaram também a viver. Obrigado pelo amparo e investimento ao longo de minha formação. Obrigado por todos os dias.

Às minhas irmãs, Aline, Andrea e Juliana, por construírem um ambiente de felicidade em nossos encontros e por habitarem a minha memória de uma forma tão especial.

Ao meu estimado orientador na PUC-Rio, professor Paulo Cesar Duque Estrada, pelo acompanhamento, respeito e dedicação. Obrigado por dizer sim, sim a esta pesquisa e assumir comigo os riscos e as boas aventuras advindas daí. Especialmente, obrigado por todos os seminários realizados na PUC-Rio que aprimoraram minha leitura da obra de Jacques Derrida.

À professora Diana Taylor e ao professor André Lepecki, por me acolherem e serem meus cotutores no período em que fui visiting scholar na New York University (NYU). Obrigado pelos cursos e diálogos que colaboraram com o aprimoramento da minha formação nos estudos de dança e da performance e que contribuíram significativamente para a elaboração desta tese.

À professora Gayatri Chakravorty Spivak, que me acolheu no seu seminário $O f$ Gramatology and Rogues, no qual pude fazer um estudo sistemático dessas duas obras de Jacques Derrida importantíssimas para o desenvolvimento desta tese.

À Pontifícia Universidade Católica do Rio de Janeiro (PUC-Rio), em especial ao seu Programa de Pós-Graduação em Filosofia, pela infraestrutura, qualidade de ensino e auxílios concedidos, sem os quais este trabalho não poderia ter sido realizado.

À Coordenação de Aperfeiçoamento de Pessoal de Nível Superior (Capes), pelo apoio financeiro na concessão de bolsa para o doutorado sanduíche no exterior e de bolsa de doutorado. 
À New York University (NYU), em especial ao Department of Performance Studies, que me acolheu como visiting scholar durante o período de estágio doutoral no exterior, pelo doutorado sanduíche da Capes.

Ao Hemispheric Institute of Performance and Politics da NYU (Hemi-NYU) e a todos os seus pesquisadores e funcionários, pelo acolhimento caloroso na universidade.

À Universidade Federal do Rio de Janeiro (UFRJ), em especial aos funcionários, professores e estudantes do Departamento de Arte Corporal da Escola de Educação Física e Desportos (DAC-EEFD).

Às professoras Alice Serra (UFMG) e Luisa Severo Buarque de Holanda (PUCRio) e aos professores Luiz Camillo Osorio (PUC-Rio), Charles Feitosa (Unirio) e Marcus Vinicius Machado (UFRJ), por aceitarem compor a comissão examinadora desta tese de doutorado.

Aos artistas Dani Lima, Denise Stutz e Marcelo Evelin, que colaboraram com esta pesquisa cedendo materiais (vídeos e fotos) para estudo de suas obras.

À amiga Iara Sales e a seu companheiro, também meu amigo, Tonlin Cheng, pelos encontros quase diários. Obrigado por seguirem dançando comigo ao longo de todos esses anos de parceria e por me apoiarem ao longo de toda a escrita desta tese.

Ao amigo Marcial Godoy-Anativia, diretor associado do Hemi-NYU, que me incentivou calorosamente antes e durante a minha estadia na cidade de Nova York. Obrigado pelos momentos de reflexão, carinho e diversão na cidade. Sem você, não teria realizado o período na NYU de forma tão proveitosa.

Aos amigos Ángeles Donoso Macaya e Cesar Barros, que também me acolheram na cidade de Nova York muito calorosamente e com quem me encontrei quase todos os dias por lá. Obrigado por serem meus interlocutores ao longo de toda a pesquisa desde então. Obrigado pelos seminários, congressos e cursos que participamos juntos. E, sobretudo, obrigado por não deixarem a dureza de NYC chegar até mim nem mesmo nos dias de inverno mais rigoroso.

Ao amigo e colega de doutorado André Stock, pela disponibilidade de interlocução e pelo apoio dado ao longo desta pesquisa. Obrigado por ser um dos meus primeiros leitores e ter me incentivado na escrita desta tese.

Aos amigos Judite Araújo e Herbet Cunha, pelo companheirismo e pelos sorrisos e encontros no Rio de Janeiro. Obrigado por me fazerem sentir querido e poder retribuir o gesto.

Às amigas Lídia Larangeira e Maria Alice Poppe, também colegas de trabalho, com quem tenho construído uma rede colaborativa de pesquisa e processos artísticos em dança dentro e fora da UFRJ. 
À amiga e professora Lúcia Fernandes Lobato e sua família, Mariana Lobato, Marcos Lobato e Silvana Lobato, pelo apoio ao longo de minha formação e pela acolhida no Rio de Janeiro. A Lúcia, especialmente, dedico esta tese, pelo incentivo à formação acadêmica e, sobretudo, por ter me apresentado à filosofia $\mathrm{e}$ às leituras de Jacques Derrida.

Ao revisor Antonio Lamenha, pela dedicação, paciência e colaboração na finalização desta tese.

A todos que colaboraram com esta pesquisa e com o meu processo de formação acadêmica e artística, entre a filosofia, a dança, a performance e além.

Muito obrigado. 


\section{Resumo}

Andrade, Sérgio Pereira; Duque Estrada, Paulo Cesar. Quando o pensamento vem dançando, quando a soberania treme - evento por vir, democracia por vir, razão por vir. Rio de Janeiro, 2016. 259 p. Tese de Doutorado - Departamento de Filosofia, Pontifícia Universidade Católica do Rio de Janeiro.

Esta tese discute relações ético-políticas entre o pensar a dança e o pensar a filosofia a partir da desconstrução de Jacques Derrida. Toma como premissa que a dança performa um modo de pensamento desafiador para a herança arquipedagógico-filosófica que encerra a filosofia na tarefa restrita ao cálculo apreensível e antecipatório mano-visual. Em sua aproximação, o que entendemos como pensamento da dança faz tremer essa perspectiva, o que não significa dizer que a dança e seus artistas tenham meios para questionar a filosofia, mas que são portadores de um "pensar" que não se encerra no campo da produção conceitual filosófica. Assim, com a aproximação entre dança e filosofia, pretende-se explorar algumas possibilidades que se abrem, em tal encontro, para a experiência de um pensamento transdisciplinar e não conceitual. $\mathrm{O}$ argumento é desenvolvido a partir de três importantes noções pensadas pelo filósofo franco-argelino: evento por vir, democracia por vir e razão por vir - que são suplementares à tarefa de abertura radical do "sim, sim ao pensar". Outras temáticas derridianas correlacionadas à discussão que aqui se propõe são abordadas, como: o direito à filosofia, a questão da ipseidade, a espectralidade, o mal de arquivo, o fator econômico circular e narrativo e o "pensar em não ver". Apesar de se concentrar majoritariamente em questões lançadas por Derrida, esta tese evoca um tom multiautoral, combinando outras assinaturas de filosofia, teorias da dança e estudos da performance (bem como obras de dança e artes da performance).

\section{Palavras-chave}

Desconstrução; soberania; pensamento; dança; performance; democracia por vir; razão por vir; evento por vir. 


\section{Abstract}

Andrade, Sérgio Pereira; Duque Estrada, Paulo Cesar (Advisor). When thought comes dancing, when sovereignty trembles - event to come, democracy to come, reason to come. Rio de Janeiro, 2016. 259 p. PhD Dissertation - Departamento de Filosofia, Pontifícia Universidade Católica do Rio de Janeiro.

The dissertation discusses ethical and political relations between thinking dance and thinking philosophy with Jacques Derrida's deconstruction. Its premise is that dance performs a way of thinking that challenges the arch-pedagogyphilosophical heritage that closes philosophy at the restricted task of hand-visual calculation. In its approach, what we understand as dance's thought shakes this perspective, which doesn't means that the dance and its artists have the means to question the philosophy, but who are carriers of a "thinking" that does not end in the field of philosophical conceptual production. Thus with the approach between dance and philosophy, we intend to explore some possibilities that open for the experience of a cross-disciplinary thinking and not conceptual. The argument is developed from three important notions designed by the French-Algerian philosopher: event to come, democracy to come and reason to come - that works together in the radical opening task of "yes, yes to the thinking". Other Derridean themes are dialogued as: right to philosophy, ipseity, spectrality, archive fever, narrative and circular economic factor and "blind thinking". Although the dissertation is focused mainly on Derrida's proposals its text evokes a multiauthorial tone, combining other signatures of Philosophy, Theories of Dance and Performance Studies, as well as works of dance and performance.

\section{Keywords}

Deconstruction; sovereignty; thinking; dance; performance; democracy to come; reason to come; event to come. 


\section{Sumário}

1. Marcas Preliminares

2. Right to Philosophy, Right to Dance... Assim Mesmo na

Língua do Outro

2.1. Filosofia e Democracia Por Vir: Sim ao Pensar! De Que

Direito-Direto?

3. Escrever e Seguir Danças com Derrida Para Além de Derrida

4. A Urgência do Fim e as Composições de Nós Para Além de Nós

5. No Rastro da Força Fraca: Performance,

Espectralidade, Economia Circular e Turbulência

5.1. Turbulência, Divisibilidade e Sofrimento de Partida:

do Mal de Arquivo da Dança e da Performance

5.2. Uma Quase Carta. Porque Não Pude Falar:

Pensando a Disjunção da Memória em Finita, de Denise Stutz 172

5.3. De Outra Turbulência: Chamada de/ Chamada à Baderna

6. Navegações e Paragens: Filosofia Enlutada, Teorização Por Vir, Pensar em Não Ver 204

6.1. Saltando Para Uma Teorização Por Vir na Dança 218

6.2. Da Escuridão e dos Enceguecimentos em De Repente Fica

Tudo Preto de Gente, de Marcelo Evelin 229

7. Considerações Finais

8. Referências bibliográficas 
A grande dificuldade é necessidade de entregar a dança, o tempo da dança, à "revolução".

Jacques Derrida, Chorégraphies. 


\section{Marcas Preliminares}

É preciso ler os suplementos, todos eles, quanto seja possivel. Essa declaração não é uma advertência nem um conselho. Talvez seja uma necessidade de, antes de tudo, desde a abertura daquilo que chamamos corpo de uma tese de doutorado, desde sua primeira seção textual, marcar esse compromisso de um "é preciso..." singular como um "é preciso ler os suplementos", já pedindo perdão ao leitor pelo excesso e pela falta que se abrirá no jogo de suplementaridades impressas a seguir. Por ora, esse é um primeiro convite, uma primeira abertura à discussão que se imprimirá a partir de agora. Que tempo é esse: "a partir de agora"? Como calcular esse tempo? Aquando e de onde? Em vistas de quê? Essas são perguntas que nos assombrarão ao longo das rotas entre os textos e seus suplementos por vir. Por enquanto, peço o tempo, já sofrendo da falta e da necessidade de tempo necessário para se pensar essas questões.

Esta é uma tese de doutorado em Filosofia. Ela está sendo escrita já se arquivando e já participando de uma certa experiência de filosofia, já a partir de uma certa consignação e repetição que esse chamado, "filosofia", imprime. Nesta tese, por sua vez, escrevo sobre relações entre pensar com a filosofia e pensar com a dança, trajetória que já venho traçando desde o meu primeiro Mestrado em Artes Cênicas $^{1}$, que se desdobrou no Mestrado em Filosofia ${ }^{2}$, tendo como referência filosófica mais recorrente o pensamento do filósofo franco-argelino Jacques Derrida $^{3}$. Na atual etapa, como doutorando, identifico uma singularidade impulsionadora dessa investigação em curso que diz respeito à reflexão do tipo de

\footnotetext{
${ }^{1}$ Cf. ANDRADE, 2010.

${ }^{2}$ Cf. ANDRADE, 2013 b.

${ }^{3}$ Permitam-me fazer um breve relato sobre mim, como um suplemento em rodapé: Sou Sérgio Pereira Andrade, esta é minha tese de Doutorado em Filosofia pela Pontifícia Universidade Católica do Rio de Janeiro (PUC-Rio). Sou Mestre em Filosofia pela PUC-Rio, Mestre em Artes Cênicas pelo Programa de Pós-Graduação em Artes Cênicas da Universidade Federal da Bahia (UFBA) e Licenciado em Dança pela Escola de Dança da UFBA. Desde 2012, sou Professor Assistente do Departamento de Arte Corporal da Universidade Federal do Rio de Janeiro (DACUFRJ), departamento onde, desde 1994, é oferecido o curso de Bacharelado em Dança da UFRJ e que, recentemente, no ano de 2010, inaugurou os cursos de Licenciatura em Dança $e$ Bacharelado em Teoria da Dança - sendo este último, atualmente, único no Brasil. O meu ingresso como professor na UFRJ, no ano de 2012, veio através de uma vaga para docente no curso de Bacharelado em Teoria da Dança, o que, no entanto, não me exime de participar como docente dos outros cursos oferecidos pelo DAC. Tenho atuado nos três cursos.
} 
contribuição sistemática que as teorizações em dança têm produzido no exercício de pensar a dança e que têm se formulado a partir da proximidade entre campos do conhecimento que excedem e fazem transbordar o domínio da Dança. Cada vez mais, é recorrente o interesse de diversas áreas acadêmicas pela dança, mas me parece que a questão sobre a singularidade do "pensamento de dança" (onde o de não representa nenhuma propriedade) e de seu exercício ainda é uma lacuna entre muitos estudos. É nessa singularidade que minha investigação encontra uma brecha a se pensar entre a filosofia e a dança: no limite do pensamento.

É preciso lembrar que, como afirma Derrida, em Pensar em Não Ver (2012):

O pensamento não se reduz nem à razão, nem ao saber, nem à consciência; há pensamento inconsciente, há um pensamento irracional, há um pensamento sem conhecimento: Kant distingue muito rigorosamente entre a ordem do pensável e a ordem do cognoscível. Posso pensar, denken, muitas coisas que posso não conhecer ${ }^{4}$.

Para Derrida, a palavra pensar é uma das mais obscuras e enigmáticas, um ponto cego no nosso vocabulário, a qual na tradução de uma língua a outra pode ter alcances semânticos diferentes, nos lembrando também da salutar contribuição de Heidegger, afirmando que a filosofia é apenas um modo de pensamento $^{5}$. Nesse sentido, não seria precipitado apelar a uma singularidade de um pensar que se dá com a dança, ou ainda, um pensamento que vem dançando. Porém tal pensamento, digno de nome, não se coloca refém da filosofia e até mesmo pode questionar, provocar fissuras no modo operatório do pensamento filosófico sem que para isso afirme nenhuma autoridade sobre a filosofia. Pois, como ainda afirma Derrida, essa potencialidade de questionar a filosofia, ir além da filosofia, "não quer dizer que um pintor ou um diretor de cinema [como também um bailarino, performer ou coreógrafo] tenha meios para questionar a filosofia, mas que o que ela ou ele cria torna-se portador de algo que não pode ser

\footnotetext{
${ }^{4}$ DERRIDA, 2012, p. 74.

${ }^{5}$ Diz Derrida: "Quando Heidegger se pergunta $O$ que chamamos de pensar? (Was heißt Denken?), "O que quer dizer pensar?", sabemos previamente que para ele o pensamento não se reduz à ciência, nem à razão, nem à filosofia. (...) O pensamento é também pensável em um movimento pelo qual ele [o pensamento] chama a vir, ele chama, ele nos chama, mesmo que não saibamos de onde vem o chamado, o que significa o chamado; ele chama. (...) Questão de hospitalidade: o pensamento chama, ele é hospitaleiro em relação a quem vem, justamente (DERRIDA, 2012, pp. 74-75).
} 
controlado pela filosofia. Assim há pensamento ali”6

Nessa noção de pensamento exorbitante, "algo que não pode ser controlado pela filosofia", ao mesmo tempo que a arte pode ser um escape e uma resistência ao controle próprio da tradição metafísica, o interesse da filosofia $e d e$ seus homens ${ }^{7}$ pela coisa artística é notável. Contudo - e é dessa perspectiva que a desconstrução derridiana quer escapar - , tal aproximação é por vezes marcada pela hipertrofia da visão que reduz a coisa visada; uma não alteridade que atrofia o modo de pensamento ao imperativo do equipamento visual. O olho que distancia e calcula teoreticamente pouco diz respeito a um modo de pensamento como a dança, que se dá corpo a corpo, numa outra espacialidade para além da visão [afinal, aquele que dança não vê o traço que dança... há uma cegueira constitutiva ali... e eu tomo como premissa nesta pesquisa que dançar é um modo de pensar]. Se fizéssemos uma rápida pesquisa entre as teses filosóficas em que a dança aparece ali como um interesse de investigação, veríamos que na maioria

\footnotetext{
${ }^{6}$ Idem, p. 47 [Comentários meus].

${ }^{7} \mathrm{O}$ grifo destaca a tradição de experiência comunitária da filosofia, um certo poder dizer "nós" na filosofia como desde sempre marcado pela noção de homem e seu privilégio topológico; o falogocentrismo pensado por Derrida que aproxima a filosofia e o direito, como também pensamento e poder marcados pelo retorno à arquiviolítica patriarcal. Arquiviolítica, por sua vez, é uma noção derridiana para se pensar a pulsão de morte da economia do arquivo, sua violência por supressão, repressão ou recalque, seu acúmulo, consignação e partilha. Em Mal de Arquivo (2001), Derrida rememora como a noção de arkhê, arquivada na palavra arquivo, ao mesmo tempo determina o começo e o comando do espaço filosófico: "ali onde as coisas começam - princípio físico, histórico e ontológico — , mas também o princípio da lei ali onde os homens e os deuses comandam, ali onde se exerce a autoridade, a ordem social, nesse lugar a partir do qual a ordem é dada - princípio nomológico" (DERRIDA, 2001a, p. 11). Derrida grifa “ali onde” e "nesse lugar" para marcar: ali onde habita uma certa tradição, onde se dá início à lei da tradição, à consignação e ao comando de uma tradição, já e ainda nesse lugar da impressão, da escrita, da marca, da passagem do privado ao público. No deslize entre o oikos [casa] e o nomos [lei] do arquivo, Derrida nos lembra da figura dos arcontes, cidadãos gregos (e não esqueçamos que a noção de cidadão grego era reservada, exclusivamente, aos homens gregos) responsáveis não somente pela segurança física do depósito e do suporte, mas também pelo direito e pela competência hermenêutica. Os arcontes, homens gregos que tinham o poder de interpretar os arquivos, "evocavam a lei e convocavam a lei", diz Derrida. "Para serem assim guardados, na jurisdição desse dizer a lei eram necessários ao mesmo tempo um guardião e uma localização. Mesmo em sua guarda ou em sua tradição hermenêutica, os arquivos não podiam prescindir de suporte nem de residência. Foi assim, nesta domiciliação, nesta obtenção consensual de domicílio, que os arquivos nasceram. (...) Em tal estatuto, os documentos, que não são sempre escritos discursivos, não são guardados e classificados no arquivo senão em virtude de uma topologia privilegiada. Habitam este lugar particular [eu diria, ainda, "particular homossocial"] , este lugar de escolha onde a lei e a singularidade se cruzam no privilégio. No cruzamento do topológico e do nomológico, do lugar e da lei, do suporte e da autoridade, uma cena de domiciliação torna-se, ao mesmo tempo, visível e invisível. (...) Remetem todas a esta topo-nomologia, a esta discussão arcôntica de domiciliação, a esta função árquica, na verdade patriárquica, sem a qual nenhum arquivo viria à cena nem apareceria como tal. Para se abrigar e também para se dissimular" (idem, p. 3). Derrida, assim, nos faz pensar a dissimetria comunitária do espaço filosófico que, ao dizer "nós", já reinscreve um espectro patriárquico da herança falogocêntrica ocidental. Esse espectro nos perseguirá e será perseguido algumas vezes nesta tese. Retomemos.
} 
dos casos, entre as poucas recorrências, a dança sequer é tratada como modo de pensamento.

Talvez, poder-se-ia arriscar uma recorrência - repito, nos poucos casos em que a dança aparece como interesse de interlocução - de um olhar sobre a dança, concordando com Marie Bardet em seu recente livro Penser et Mouvoir: une rencontre entre danse et philosophie (2011), que, na ainda mais recente tradução para o português, foi intitulado A Filosofia da Dança: um encontro entre dança e filosofia ${ }^{8}$ (2013). Segundo Bardet, haveria um olhar sobre a dança a partir dos "usos da imagem da dança que quase sempre é a da dançarina, em algumas citações da filosofia... [onde] a dançarina faz alguns passos sobre as pontas dos pés, se atira, rodopia e estimula assim o espírito do filósofo em sua suposta elevação" ". Acredito que o trabalho de Bardet [que encontrei numa de minhas garimpagens em livrarias virtuais, na internet, ao longo desta pesquisa] aponta muitas saídas sobre essa cena capciosa - continuaremos dizendo, outra vez, rara? É uma cena rara? - do filósofo (ele) diante da dançarina (ela), o sujeito estimulado pelo objeto-sopro, quando pensamento e peso - o pe(n)sar - jogam com arquétipos de leveza e relações de gênero. Mas Bardet escolhe referências bem pontuais na história do pensamento ocidental, traduzido como A Filosofia, uma certa evocação de uma ontologia em que a discussão que vínhamos tentando iniciar acima parece ainda não contemplada: um outro apelo por uma singularidade de um pensamento que vem dançando... ou melhor, um quando a dança vem. Essa vinda já cega, já pensamento, já dança e mesmo quando já, um já também atrasado. A abertura e a disjunção injuntiva provocadas na turbulência de uma dança ${ }^{10}$.

As contribuições de Derrida quanto à noção de pensamento aparecem em muitos de seus trabalhos, deixando brechas para se pensar outros modos de pensamento, como a singularidade do pensamento de dança, ao passo que sugerem desafios a uma certa tradição da filosofia. Derrida tensiona a soberania e o logocentrismo do pensamento filosófico, apelando "ao pensamento do evento por vir, da democracia por vir e da razão por vir" (que ele também chama de

\footnotetext{
${ }^{8}$ A tradução de Penser et mouvoir por A Filosofia da Dança é no mínimo curiosa.

${ }^{9}$ BARDET, 2013, p. 24-25, grifo meu.

${ }^{10}$ Discutirei essa temporalidade out of joint ao longo da tese, sobretudo na quinta seção deste volume - No Rastro da Força Fraca: Performance, Espectralidade, Economia circular $e$ Turbulência.
} 
“mundo das luzes por vir" $)^{11}$. Em outros momentos, apela também ao pensamento cego, sugerindo inclusive o deslocamento da discussão das artes visuais para o que ele chama de artes espaciais $^{12}$ para pensar a resistência da arte à filosofia, sobretudo à presumida autoridade hegemônica e fenomenológica do discurso filosófico sobre a arte, afirmando que: “(...) é no interior de uma certa experiência do espaçamento, do espaço, que a resistência à filosofia pode ser produzida. Em outras palavras, a resistência ao logocentrismo tem uma chance maior de aparecer nesses tipo de arte [as artes espaciais]"13.

Essas desconstruções de Derrida são transversais e suplementares, portanto assombraram a escrita desta tese de forma disseminativa, chegando em tempos diferentes, ora se reunindo numa leitura específica, ora se dispersando entre muitas textualidades, coreografando experiências de pensamento nunca autocentráveis. A abertura para tal movimento foi conduzindo a pesquisa a se debruçar sobre a pergunta: o que poderia se chamar pensamento quando dança e que espacialidade política essa singularidade encetaria?

Seguir essa pergunta assombrados pela desconstrução de Derrida, por sua vez, nos conduziu a uma feliz ${ }^{14}$ abertura para se pensar a turbulência de um pensamento que vem dançando, pois nas palavras do autor, em uma das poucas vezes em que ele se referiu à dança mais diretamente, "a mais inocente das danças já contraria toda atribuição de uma residência, escapa a essas residências sob vigilância; a dança muda de lugar e acima de tudo muda os lugares. Em seu rastro, os lugares não podem ser mais reconhecidos" ${ }^{15}$. Se, também como nos disse o autor, a herança do pensamento filosófico é marcada pela arquiviolítica desde o falocentrismo do princípio arcôntico, a proposta que se performa nesta tese é a de pensar como a força do pensamento quando dança, em sua temporização

\footnotetext{
${ }^{11}$ Tais discussões são notadamente trabalhadas por Derrida em Who's Afraid of Philosophy? Right to Philosophy I (2002) e Vadios - Dois Ensaios Sobre a Razão (2009), que serão abordados na segunda e na sexta seção desta tese: Right to Philosophy, Right to Dance... Assim Mesmo, na Língua do Outro; e Navegações e Paragens: filosofia enlutada, teorização por vir, pensar em não $v e r$, respectivamente.

${ }^{12}$ As noções de pensamento cego e de artes espaciais são trabalhadas por Derrida em Memórias de Cego (2010) e Pensar em não Ver: escritos sobre as artes do visível (2012), que são, especificamente, abordados na terceira e sexta seção deste volume - Seguir Danças com Derrida para além de Derrida; e Navegações e Paragens: Filosofia Enlutada, Teorização Por Vir, Pensar Em Não Ver, respectivamente.

${ }^{13}$ DERRIDA, 2012, p. 21.

${ }^{14}$ No sentido austiniano de performativo feliz como uma efetividade (AUSTIN, 1990), mas também como perturbadora alegria vinda do "sim" ao pensar.

${ }^{15}$ DERRIDA, 1994, p. 145.
} 
disjuntiva e demandadora de outra forma de se pensar o arquivo ${ }^{16}-$, pode brilhar além da clausura.

Esta tese, portanto, abre-se à discussão do pensamento de/quando dança; o dar e compor da experiência de pensamento no chão da dança, ainda quando circulando no chão da filosofia - e chão aqui estrategicamente é invocado para se fazer tremer uma certa lógica de horizonte de sentido; chão, antes de tudo, é o suporte da negociação com o gravitacional, de salto, mas também de queda. Não pretendo aqui, pensando no limite, tratar da dança como uma configuração ou objeto estético, o que não quer dizer que em algum momento não recorra a tais recursos de análise, mas, talvez, esteja mais interessado em pensá-la (a dança) como um acontecimento, uma espacialidade que produz campos de força pela mobilidade entre corpos e meta-corpos e dá a pensar a dança, já também dançando. Um certo aí turbulento, que existe apenas como rastros de rastros ${ }^{17}$ que se deslocam; uma certa reunião, um certa experiência/experimento de dança.

O pensamento de tal força está para além do espaço consensual do que se diz e se chama dança, para além e no limite do sentido de obra de arte. Ou seja, estou necessariamente falando de uma dança que vem tensionada, assinada e contra-assinada pela alteridade. Ainda enquanto uma obra de arte, a espacialidade de uma dança, como apresentada pela noção de artes espaciais sugerida por Derrida (2012), é feita sempre em relação ao outro, afirmada pelo outro (circuitos, instituição, linguagem, outrem etc.), num espaço público e, portanto, num espaço político. Nesse sentido, esta pesquisa ainda se dedica a tensionar os limites políticos de um acontecimento de dança e de pensamento.

Pode um acontecimento se dar como dança mesmo não estando diante daquilo que se anuncia como tal? Mesmo que não se veja nem se apresente uma obra, pode acontecer aí uma dança como pensamento? Não me refiro aqui à

\footnotetext{
${ }^{16}$ Discuto essa questão em No Rastro da Força Fraca - quinta seção desta tese.

${ }^{17}$ A noção de rastro empregada ao longo da tese segue a definição do pensamento paradoxal de Jacques Derrida como inscrição e relação com o outro que se autoapaga em seu porvir. Refere-se à força de temporalização de qualquer inscrição anterior ao ente, ser, signo ou aquilo que se chama de experiência. Pode-se dizer, também, que se refere à força de lei que opera o por-vir como repetição iterável. "A estrutura geral do rastro imotivado faz comunicar na mesma possibilidade e sem que possamos separá-los a não ser por abstração, a estrutura da relação com o outro, o movimento de temporalização e a linguagem como escritura. Sem remeter a uma 'natureza', a imotivação do rastro sempre veio-a-ser. Para dizer a verdade, não existe rastro imotivado: o rastro é indefinidamente o seu próprio vir-a-ser-imotivado" (DERRIDA, 1973, p. 58, grifos do autor). Imotivada inscrição sem originário simples, jamais se deixando reduzir ao Um. Rastros só nos levam a outros rastros. Rastros de rastros, portanto.
} 
abstração, à virtualização ou ainda à imaginação de uma dança. A minha pergunta é de uma outra temporalização; nem aquém nem além da abstração, da virtualização e da imaginação. Mais radicalmente, a dança pode propor ambientes, tensões e aberturas para pensar o político, a justiça e a democracia? De que direito? Quando pensamos esses temas [tradicionalmente arquivados no espaço de direito da filosofia] em deslocamento com a dança estamos circulando no chão da dança ou da filosofia?

Esta tese, ainda, quer pensar o percurso que se segue na experiência de sua inscrição e, portanto, adota, performativamente, a incorporação das escritas que se produzem na saída do ambiente acadêmico-familiar sobre a mesa para a rua, na mudança de suportes. Nesse sentido, importa destacar também, neste meu percurso de pesquisa, o período de realização do estágio doutoral, de abril de 2014 a maio de 2015, na New York University (NYU), através do Programa de Doutorado Sanduíche no Exterior (PDSE), da Coordenação de Aperfeiçoamento de Pessoal de Nível Superior (Capes), como pesquisador visitante do Hemispheric Institute of Performance and Politics e do Departamento de Performance Studies da Tisch School of Arts, sob a cotutoria do Prof. Dr. André Lepecki e da Profa. Dra. Diana Taylor - ambos, a quem agradeço calorosamente a oportunidade de diálogo. O período do doutorado sanduíche oportunizou o aprofundamento dos meus estudos acerca das teorias das artes do corpo e atuais discussões do campo, pertinentes ao projeto de pesquisa, tendo acesso a toda a rede de bibliotecas sediadas em Nova York. Além disso, propiciou a participação em cursos, seminários e grupos de estudo na cidade. Destaco, aqui, o seminário de doutorado Of Gramatology, ministrado pela Profa. Dra. Gayatri Chakravorty Spivak, na Columbia University, em que abordou criticamente sua histórica tradução - que em 2016 aniversaria 40 anos - para a língua inglesa de De la Gramatologie (1967), de Derrida, fazendo, ainda, uma relação com o último livro publicado pelo pensador, Voyous $(2003)^{18}$.

A escrita desta tese está também assombrada por muitas outras referências que escapam ao suporte da mesa; cenas que foram acontecendo ao longo dos anos de pesquisa. Escrevi em pleno movimento de tomada das ruas nas

\footnotetext{
${ }^{18} \mathrm{O}$ seminário foi crucial para o desenvolvimento do argumento desta tese e, portanto, estendo meus sinceros agradecimentos à Dra. Spivak por seu gesto de hospitalidade e interlocução rigorosa.
} 
diversas capitais brasileiras em junho de 2013. Escrevi em meio ao reacendimento do movimento feminista no Brasil; em meio aos processos de remoções de casas populares e da destruição da Aldeia Maracanã, no Rio de Janeiro, para a acomodação de grandes eventos esportivos corporativos - a Copa do Mundo de 2014 e os Jogos Olímpicos de 2016. Escrevi quando, em Nova York, o movimento Black Lives Matter ocupou as ruas para denunciar a gritante desproporção da violência policial norte-americana contra a população negra naquele país - e não somente lá, nos Estados Unidos, pois também escrevi, a distância, quando a chacina patrocinada pelo Estado da Bahia e sua polícia armada matou doze jovens negros no bairro do Cabula, zona urbana quilombola de Salvador, onde vivi até os 25 anos de idade, antes de me mudar para o Rio de Janeiro; lá onde ainda vive minha mãe, meu pai e minhas irmãs, tios, tias, primos e primas. Escrevi quando 43 estudantes de Ayotzinapa foram assassinados e desaparecidos no México, ato também patrocinado pelo Estado mexicano. Escrevi quando os professores da UFRJ entraram em greve em 2015, junto ao Sindicato Nacional dos Docentes das Instituições de Ensino Superior (Andes-SN) e ao Movimento Estudantil, pela manutenção do caráter público e gratuito da Educação Brasileira, hoje cada vez mais sufocada pela pressão das empresas que fazem da Educação um negócio; a greve iniciada na UFRJ pelo Movimento Estudantil tomou lugar dois dias depois do meu retorno da temporada em Nova York. Escrevi quando estudantes secundaristas de São Paulo, do Rio de Janeiro e de outros estados ocuparam as escolas de Ensino Básico e resistiram à truculência da polícia e ao terrorismo de Estado (outra vez)... Escrevi dramaturgias para Iara Sales e Tonlin Cheng dançarem a obra PEBA; a distância, dancei com eles e viajei com eles - muitas viagens, para ir dançar junto a eles. Iniciei, já no final da tese, uma outra dramaturgia, com Lídia Larangeira, para Brinquedos para Esquecer. Escrevi depois do crime ambiental cometido pela empresa Samarco que devastou as cidades de Mariana e Bento Rodrigues, em Minas Gerais, e vi o barro chegar aos rios das cidades do Espírito Santo durante uma viagem que fiz de carro, do Rio de Janeiro a Salvador, com os amigos Ángeles Donoso e César Barros, e tive medo de ver a lama chegar ao sul da Bahia. Escrevi em meio ao estado de baderna da política brasileira. Manifestações, protofascismo, impeachment, ocupações... Baderna, esse também nome de uma bailarina... um estado dançante, 
quem pode proferir esse chamado? Estados de baderna, a quem interessa interpelar? ${ }^{19}$.

Escrevi aqui e lá, ao mesmo tempo e em tempos diferentes. Ora atrasado, depois como quem responde a uma catástrofe, ora fugindo do tempo, des-ritmado. Escrevi multiplicando e deslocando as superfícies. Escrevi no chão. Escrevi no papel e no computador. Escrevi em muitos suportes - ainda que essa palavra não suporte o que quisesse mesmo escrever aqui. Tive que escrever em inglês e também em espanhol. Escrevi com outros acontecimentos de que já nem me lembro. Mas ainda guardo as impressões dos sprays de pimenta, mais uma vez, na rua. E quanto pode suportar um corpo?

Numa tese de filosofia, quanto pode suportar o seu corpo? Interessa pensar o peso da trajetória de um pensamento? Os deslocamentos, os pequenos ajustes no tempoespaço, as resistências, a perda e a retomada de fôlego, o seguir desse movimento quasesempre de improviso dizem sobre uma filosofia que vem dançando?

Ao longo da escrita [e talvez preferisse dizer escritas, no plural, pois há sempre mais de uma], procurei ajustar o melhor tom de como lidar com os atravessamentos que me chegaram pelo labor de uma tese. Mais do que uma escrita analítica

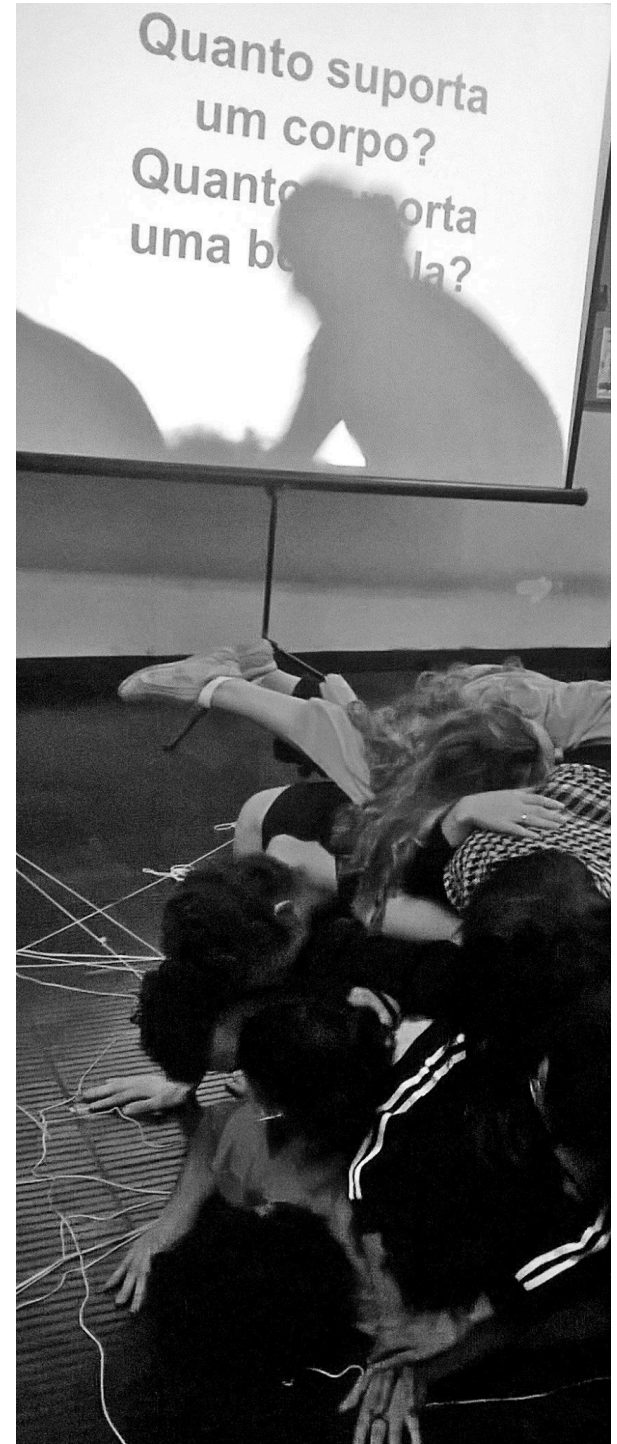

Quanto suporta um corpo? Quanto suporta uma berinjela? Palestraperformance de Sérgio Andrade, 2015. Foto: Fabiana Nogueira, 2015. traçando um horizonte muito bem definido sobre determinados autores e conceitos, esta tese cria tensões sobre a maneira de como colocar uma questão, o modo como se deve tratar uma questão, o que pode vir a ser relevante ou não como questão. Talvez, um leitmotiv que sempre retorna

\footnotetext{
${ }^{19}$ Pensarei sobre essa dança perturbadora que tal palavra guarda em segredo no final da quinta seção desta tese.
} 
ao acontecimento deste texto é: ao mesmo tempo que escrevo e sou lido, em qual tom se deve dar a pensar uma tese que lida com fronteiras? Mais do que determinar a tese, como desenhar as mudanças de tom, as passagens e as traduções?

$\mathrm{Na}$ tentativa de insistir e me demorar sobre esta última pergunta, adotei uma postura performática, enxertando a argumentação de comentários, anedotas, memórias, rastros autobiográficos e outras ruínas de pensamento ${ }^{20}$. O outro que vem é disseminado e lançado ao porvir da textualidade. Incorporei/excorporei, como um lance telecoreográfico ${ }^{21}$.

Nas minhas dissertações de Mestrado em Filosofia (2013) e Mestrado em Artes Cênicas (2010), me detive a realizar escritas mais analíticas sobre autores e conceitos que acompanhavam meus estudos. Porém, agora no doutorado, tomo como tarefa a necessidade de contribuir para os campos de pesquisa em que estou imerso (dança, performance e filosofia) de outro modo, assumindo outro tom, ao mesmo tempo que dou continuidade às margens que venho traçando no exercício do pensar e sugerindo outros desvios, desde o tom da escrita.

Por ora, é oportuna a diferenciação heideggeriana entre denken, o pensar, e danken, a gratidão, que marca o agradecimento em relação ao outro que vem como pensamento. $\mathrm{O}$ tom buscado nesta tese foi no sentido de responder ao outro que vem incondicionalmente. Um pensamento que assim acolhe a vinda do outro que vem, mesmo sem avisar, multiplicando-o e dispersando-o em várias vozes, tons que escapam. Tal composição muito comum em textos de Derrida, provoca um efeito plus d'une langue [que ao mesmo tempo performatiza "mais de uma língua" e "basta de/não mais" uma língua]. A passagem de uma língua a outra, de uma voz a outra, de um tom a outro arquiteta e antecipa desde a escritura uma

\footnotetext{
${ }^{20}$ Desde a minha dissertação de Mestrado em Filosofia, Traição em Desconstrução: sobre a tradução, o subjétil, a dança e além (2013), tenho justificado que o tom autobiográfico que parece escapar em minha escrita, bem como as múltiplas vozes que surgem daí, diz respeito, talvez, à incondicional monolíngua do outro, tal como pensada por Derrida, como a lei da língua e a língua como lei: "sim, eu não tenho senão uma língua, ora ela não é minha"; "a língua é vinda do outro e ao outro regressada" ( $c f$. DERRIDA, 2001b). O dizer eu é desde sempre a vinda do outro e ao outro enviado; digo eu numa língua que a tenho como se fosse minha, mas desde sempre foi uma língua vinda do outro e para o outro enviada. Tal incondicionalidade perturba o retorno a si de toda subjetividade. Não há nenhuma soberania autoritária aí. Quando digo eu, o faço desde sempre assombrado pela alteridade. (Cf. ANDRADE, 2013b.)

${ }^{21}$ Telecoreografia é uma noção que irei desenvolver ao longo de toda a tese. De uma maneira mais elíptica, telecoreografia diz respeito à força de teletransportação, tradução e iterabilidade entre gestos, coreografias, textos, chamados e rastros de rastros de pensamentos que vêm dançando. As noções de dança e de telecoreografia tomarão diferentes rotas ao longo da tese e não se restringem somente aos processos artísticos, como veremos a seguir.
} 
outra ética, outra política, outra espacialidade, outro pensamento como uma babelidade por vir.

Nas páginas que seguem, estará em cena uma escrita atravessada e deslocadora, rastros de minha experiência na dança e na performance como pensamento, que reserva uma certa despretensão no mover-se radicalmente enquanto pensar. Tenho acreditado que esse tom é digno de tese. Não somente eu, mas uma rede muito grande de pesquisadores ${ }^{22}$ vem adotando a escrita performática como uma brecha para outra forma de pensamento, sobretudo na literatura e nas artes. Meu desafio aqui é tentar trazer esse tom para uma discussão filosófica, investindo na palavra, por vezes, para além do sentido discursivo. Trata-se de uma tentativa de agenciar um pensamento no limite. A palavra, assim, deixa de ser tratada como portadora de sentido para ser um convite, um chamado à tradução. O tom vem tal como uma poemática in/ex/corporada:

Coma, beba, engula minha letra, porte-a, transporte-a em você como a lei de uma escritura tornada seu corpo: a escritura em si. A astúcia da injunção pode inicialmente deixar-se inspirar pela simples possibilidade da morte, pelo perigo que um veículo traz a todo ser finito. Você ouve a catástrofe vir. ${ }^{23}$

Assim, esta tese não se dedica a justificar práticas de dança e de performance pelas formas de pensamento da filosofia nem mesmo busca ser uma pesquisa sobre Derrida ou algum autor específico. Sim, Derrida vem repetida e incondicionalmente; está impregnado e condicionado à minha trajetória acadêmica, sobretudo na instituição filosófica e sua economia arquifalogocêntrica-pedagógica. [Desenvolvo a noção de arqui-falogocentrismopedagógico na segunda seção desta tese. Mas, por ora, quero já indicar, de maneira pontual, ainda que entre colchetes, os caminhos que se arquivam e são

\footnotetext{
${ }^{22}$ Estou aqui me referindo, sobretudo, aos pesquisadores de Performance Studies e Literatura Comparada (e autores de todo o campo da literatura), alguns deles citados ao longo da tese. Mas o pensamento dessa performatividade, da questão do estilo e do método como pensamento não é exclusivo a esses campos e aos seus sujeitos de direito. Os escritos (cartas, manuais, anotações, rabiscos) de Lygia Clark, Hélio Oiticica, Antonin Artaud, Yvonne Rainer, Andy Warhol entre tantos outros artistas que partilharam suas formas de pensamento através da experiência da palavra também poderiam ser citados aqui. Ainda Derrida, na filosofia, herdeiro de uma marca nietzschiana, experimentou a corporeidade da palavra e do texto como limite performativo de seus textos. Se há texto, a questão do tom sempre emergirá junto ao lugar e à lei para que se escreve e se arquiva (se para um livro, para um artigo ou uma conferência a ser lida e depois publicada, para uma entrevista, uma postagem nas redes sociais etc.).

${ }^{23}$ DERRIDA, 1992, p. 305.
} 
reencenados nesse lugar de fala. É de conhecimento comum - ao menos de um certo comum - que, tradicionalmente, na carreira acadêmica de filosofia, um postulante ao título de Doutor deve ter sua pesquisa vinculada a um pensador específico. Não qualquer pensador, mas sobretudo um pensador herdeiro da tradição arquiviolítica filosófica. A partilha, como também a participação, da herança da tradição filosófica é precondicionada ao performativo que quase se confunde como uma tomada de partido: é preciso se declarar herdeiro de alguém e pôr-se à prova por tal declaração; perseguir e ser perseguido por ela. A assinatura de um homem da filosofia está sempre assombrada por um outro, um espectro de um herdeiro de direito e de dom. No meu caso, preciso afirmar algo como eu-derridiano ou, ainda, eu com Derrida, para seguir dançando - mesmo quando sem dançar - na filosofia ${ }^{24}$. Derrida, como filósofo, homem de direito a filosofia, também está, de alguma maneira, enclausurado nesse arquifalogocentrismo-pedagógico. Está encenado aqui o limite da assinatura e da inscrição na tradição que atravessa esta tese. Retomemos.]

Derrida está repetidamente citado nestas linhas devido às marcas, às impressões e às fissuras (peço que deixe soar a ambiguidade desta última palavra) na minha experiência de leitor/amante de filosofia. Porém outras vozes foram também convocadas ao debate, como Kant, Marx, Freud, Heidegger, Austin e Nietzsche, autores que já aparecem muito citados entre as contribuições derridianas - são seus suplementos - e que ao longo do percurso foram se reforçando entre os textos como espectros que vinham cobrar suas heranças. Latour, Rancière e Butler também vêm à tona, de maneiras muito dissimétricas, adensando discussões que nos ajudam a pensar o limite da ética no social contemporâneo e as interfaces entre arte e política ${ }^{25}$. Paulo Cesar Duque Estrada colabora com as leituras da obra de Derrida. Alguns teóricos da dança e dos estudos da performance, como André Lepecki, Diana Taylor e Peggy Phellan, e também um biógrafo, Silverio Corvisieri, foram convidados ao debate. Ainda trabalho com duas obras contemporâneas de dança - Finita, de Denise Stutz, e De Repente Fica Tudo Preto de Gente, de Marcelo Evelin. Sem contar os

\footnotetext{
${ }^{24}$ Na terceira seção desta tese, Seguir Danças com Derrida para além de Derrida, discuto e enceno os problemas do arqui-falogocentrismo-pedagógico.

${ }^{25}$ A discussão está elaborada nas seções: 4. A Urgência do Fim e as Composições de Nós para além de Nós, com Latour e Rancière; e 5.2 De Outra Turbulência: Chamada del Chamada à Baderna, com Butler, Derrida e Corvisieri.
} 
tradutores, os outros suplementos, os personagens e as citações incidentais [quantas co-assinaturas!].

As múltiplas vozes que atravessam essa escritura vêm como fantasmas que a todo momento retornam para perturbar o texto, fazendo-o duvidar de seu curso monotônico, justamente pela tão marcada e declarada afinidade com esse outro que não assina, propriamente, este texto ou que somente pode assiná-lo como uma meta-assinatura, se a entendermos, outra vez com Derrida, como uma figura da ex-apropriação, do performativo eu ex-apropriado no papel: eu-Sérgio assino esta tese; como uma figura mal dominada da ex-apropriação em relação “a uma nova economia, ou seja, também a um novo direito e a uma nova política das próteses ou dos suplementos de origem" ${ }^{26}$. Nesta composição textual, autores e circuitos são respeitados ao mesmo tempo que são quase violentados, testados em sua finitude, nos solos, suportes e subjéteis em que circulam.

Deslocar-se em perigo, como um corpo dançante, é o tom que se busca aqui. Considero que isso de maneira nenhuma é falta de rigor no pensamento. Pelo contrário, um texto assombrado por tantos enxertos coloca em questão outro rigor quanto à mobilidade incondicional do pensamento. Um pensamento que vem dançando. Um método exorbitante, a que não se podem atribuir um lugar nem uma casa, que trafega por aquilo que chamamos de experiência como experimento, ou mesmo biografia, sem esperar nesse tráfego nenhum fundo de pouso que simplifique a experiência como origem simples. "É preciso começar de onde quer que estejamos e o pensamento do rastro, que não pode não considerar o faro, já nos ensinou que seria impossível justificar absolutamente um ponto de partida" ${ }^{27}$, nos diz Derrida. E dessa partida seguimos: "De onde quer que estejamos: já num texto em que acreditamos estar"28.

\footnotetext{
${ }^{26}$ DERRIDA, 2004, p. 238.

${ }^{27}$ DERRIDA, 1973, p. 199. Os grifos são de Derrida, mas eu também os grifaria.

${ }^{28}$ Idem.
} 
2

\section{Right to Philosophy, Right to Dance... Assim Mesmo, na Língua do Outro}

Começarei por algumas anedotas. Desvios. Esta tese está cheia deles... talvez, desviar seja a condição que se coloca quando numa experiência de limite - você tem que escrever! Ter que escrever é ter que marcar alguma superfície que me impõe abismos, limites, deadlines, folhas de papel, telas, computadores, ambientes cibernéticos etc. Escrever, inscrever sobre, é também uma performance radicalmente telemática: sobre outro e enviada alhures. O envio pode ser interceptado, repassado, destruído antes que chegue a um destinatário, negado à probidade e blindado de uma compreensão ao mesmo tempo que agencia a possibilidade de compreensão. Tal distância é incondicional da escrita sobre algo - esse algo receptáculo que não é um horizonte, mas antes de tudo um chão marcando aqui, logo no início, que parto da premissa de que se escreve como inscrição em superfícies, nos mais diversos subjéteis ${ }^{29}$, papelitudes e grafias em geral: documentos, registros, títulos, textos, coreografias, rascunhos, desenhos etc. Essa cena iterável ${ }^{30}$ me acolhe e me expulsa de casa, daquilo que posso the atribuir como tal, me põe uma incondicional distância desde aí, um é preciso ir para a rua e circular no espaço do radicalmente outro. E peço para que se inicie essa leitura inscrevendo na memória esse apelo: é preciso ir para rua!

\footnotetext{
${ }^{29}$ Escrevi sobre o subjétil em outro momento fazendo uma travessia entre Derrida e Artaud. O subjétil impulsionou o pensamento de Derrida a desenvolver questões sobre o desenho, a palavra, o corpo e o suporte em Artaud. Diz Artaud, numa carta enviada a Renéville, em 1932: "Incluo nesta [carta] um desenho ruim em que isso que se chama o subjétil me traiu"; escreve ainda outras duas vezes em seus desenhos em 1946 e 1947 sem nunca conceituá-lo enquanto ser, que ou quem. Derrida se interessa sobre a cena dessa palavra que pode ser chamada e trair. Para Derrida, o subjétil, que escapa a Artaud, por sua traição, pode abrir uma brecha para se pensar a desconstrução entre palavra e logos, entre o que está embaixo, como substrato, subjectum, súcubo e o que está em cima como superfície e matéria, e todo entre (ente ou entre mesmo?) que se distingue da forma, do sentido e da representação. Khora e alteridade anterior ao sujeito, à subjetividade e ao ser; também anterior ao sentido, ao senso e ao si. Nunca podendo se falar diretamente ao subjétil, Derrida propõe falar de sua cena, de sua força perturbadora de radical escape. $C f$. ANDRADE, 2013a.

${ }^{30}$ Noção derridiana que marca a repetição como diferença. Retornarei logo mais à questão da iterabilidade na escritura de Derrida.
} 
Num lance disseminativo, gostaria de telegrafar algumas chegadas que me vêm, me assombram e me acometem como dança - me fazendo ter que responder por seu nome, esse também subjétil a que se chama dança:

1.

07 de dezembro de 2013, pelo celular:

"Continuo arrependida de ter aceitado dançar amanhã. Dançar parece simples, mas exige muito de mim e de Tonlin. E estamos muito cansados. Acabamos por brigar, não estamos nos falando e tendo que continuar, fazendo tudo junto. Te escrevo por desabafo. E ainda existem as cólicas de uma menstruação e um não mexer o corpo há mais de um mês! Só dá vontade de chorar"

[Recebi essa mensagem quando estava escrevendo este texto. Veio de uma amiga com quem trabalho há mais de oito anos, Iara Sales, com a qual, atualmente, tenho trabalhado em seu projeto, $P E B A$, como dramaturgista. PEBA é uma proposta entre dança, performance e arquitetura sonora que pretende ser remontável em qualquer espaço, ou melhor, a ativação de $P E B A$ lembra que uma dança não se dá num lugar para dançar, mas constrói espacialidades em que pode vir a se dar uma dança. Nessa mensagem, Iara se referia à falta de ar que vem por uma dança que precisa construir fisicamente a sua espacialidade. Laborar uma dança, preparar um espaço para se dar uma dança já dançando desde aí, exige um enfrentamento: tenho que descer para a rua, lidar com o estar na rua, ao mesmo tempo que preciso lidar com as subjetividades do corpo - suas cólicas, menstruações e lágrimas - que não são uma subjetividade objetivante que habita o corpo, mas é o corpo em sua corporeidade singular. Mesmo o eu querendo ficar em casa, para se dar uma dança é preciso ir para a rua. Iara estava arrependida do convite que aceitara para ir mais uma vez para a rua e somente me escrevera como desabafo, assim sem ponto final]

2.

Era sábado, 22 de novembro de 2013, ainda muito cedo para alguém que costuma dormir por volta das 4 horas da manhã. Por volta das 9 horas, ainda quase-sonhando, de olhos fechados, escutei de longe um chamado. Era do telefone

fixo de minha casa, que quase nunca toca. Com a visão embaçada, vi que a chamada era de um número local, portanto havia pouca probabilidade de ser um anúncio de telemarketing:

- Oi, Sérgio! Ainda dormindo? Quer que retorne outra hora? - Não, não, imagina! Pode falar! Já estou quase-de-pé. 
- Então, estou te ligando para te convidar a compor a mesa do Seminário, para você falar sobre o curso de Teoria da Dança, em nome do curso de Teoria da Dança ${ }^{31}$.

[A ligação era de uma colega de trabalho, Waleska Britto, a então vicecoordenadora do Bacharelado em Teoria da Dança da UFRJ, convidando-me para o Seminário Conhecendo e Reconhecendo a Dança na UFRJ, organizado pelo Departamento de Arte Corporal. Pensei em negar o convite, mas no mesmo instante percebi que me era proferido um chamado à responsabilidade. Resolvi aceitar]

16 de abril de 2013:

Índios de diversas regiões e etnias do Brasil invadiram a plenária da Câmara dos Deputados para protestar contra a PEC 215, que prevê a transferência da competência da demarcação das terras indígenas da Fundação Nacional do Índio (Funai) para o Congresso Nacional. "No momento da invasão, os índios começaram a dançar e gritar palavras de ordem. Alguns estavam com tacapes nas mãos. A Polícia Legislativa tentou conter o grupo, mas não conseguiu" ${ }^{32}$. As cenas registradas em vídeo e disseminadas na internet mostram um alvoroço dos deputados, correndo daqueles que chegaram sem ter sido convidados. Eles entram, ocupam e dançam. "Os índios" - essa alteridade radical sempre observada como um alhures indomável.

Favor acessar o link: $<<$ https://www.youtube.com/watch?v=wSftfutY5s $>>$

Já não lembro o dia em que me chegou tal notícia, mas foi em 2012, quando soube da conferência Mergulhando na Memória, de Ann Cooper Albright, no Congresso da Associação Brasileira de Pesquisadores em Artes Cênicas (Abrace), no dia 08 de outubro de 2012: Mesmo sem ter estado lá para ver, soube que ela falara algo sobre os corpos que se jogaram do World Trade Center, no evento que ficou marcado como 11 de setembro. Frente à incondicional morte que vinha, aqueles que - por vídeo, não sabemos nem nunca saberemos seus nomes - escolheram se jogar. Não sabemos nem nunca saberemos o que de fato os

\footnotetext{
${ }^{31}$ Como já me apresentei antes, sou professor, desde o ano de 2012, do curso de Teoria da Dança, que foi lançado no ano de 2010. O fato é que o curso de Teoria da Dança é ainda muito novo; e é fato também que, mesmo eu sendo muito novo na instituição, posso ser chamado a responder por ela. Duplamente às cegas.

${ }^{32}$ Trechos da matéria "Índios invadem plenário da Câmara e interrompem sessão", de Márcio Falcão e Tai Nalon, da Folha de S.Paulo, de 16 de abril de 2013.

Disponível em: <<http://www1.folha.uol.com.br/poder/2013/04/1263651-indios-invademplenario-da-camara-e-interrompem-sessao.shtml>>; último acesso: jun. 2016.
} 
levou a essa decisão, mas soube, sem ter visto, que Albright usou as imagens desses corpos para falar de dança e performance. Soube também que ela comentava como os gestos dos corpos que se lançavam no ar eram uma dança não somente de desespero, mas também de libertação ou, ainda, último escape, último agenciamento do seu próprio fim. Assim que me acometeu tal pensamento, fui até o YouTube e encontrei estas imagens: $<<$ http://www.youtube.com/watch?v=TucV1mI68hQ >>.

[Mesmo sem ter visto Albright falar, seu pensamento me chegou como uma dança que cai de cima; que numa queda pode evocar uma chamada à responsabilidade. Imagens que martelam repetidamente: Quem assina aquela dança? Estaria ela, a dança, endereçada?]

Retorno agora a um episódio - sobre o qual já me demorei um pouco, em outro momento, em minha dissertação de Mestrado em Filosofia, como um queixume (parafraseando Derrida, "uma queixa sem acusação") - que ainda me acompanha junto às perguntas que me convocam a pensar a dança. Retornarei outra vez: estava eu frente a uma banca de homens da filosofia, os quais dariam acesso ou não à minha entrada no seu campo, na sua casa, nos limites de suas bordas [um comentário-enxerto: estar num continente, ter um papel, um lugar nele, ainda que pequenamente; estar próximo ou ter um título de direito não me reserva nenhuma certeza, nem desígnio, nem destino - é o que tentarei mostrar, trazer à mostra aqui, de alguma maneira assombrado por muitos, alguns deles ativados nestas linhas como cena $^{33}$. Nesse momento, são oportunas as palavras de Martin Heidegger (2008) que dizem: "a proximidade aproxima o distante, sem violar-lhe e sim preservando-lhe a distância. Proximidade resguarda a distância”34 . Ou seja, eu estava ali muito próximo, porém, incondicionalmente, distante daquele habitar]; falava sobre minha trajetória, às margens da filosofia, sem nunca ter carregado um título em seu nome ${ }^{35}$, sem ter que responder por tal

\footnotetext{
${ }^{33}$ Mais adiante, falarei do sentido derridiano de cena sem teatro, que se faz enquanto movimento dos corpos, manifestação no descer para a rua - passagem que sugere atravessamentos entre dança e pólis.

${ }^{34}$ HEIDEGGER, 2008, p. 155.

${ }^{35}$ É certo que naquele momento eu não tinha nenhum papel que atestasse por direito minha proximidade com a filosofia. Não carregava nenhum título stricto sensu em seu nome, com
} 
responsabilidade; falava de minha chegada até aquela mesa entre nós, onde poderiam dois homens dignos de nome e direito me olhar, antecipar-se ao que digo e um deles, sem demora, interpelar: - mas aqui você não vai dançar, né?

Sempre gosto de retornar vertiginosamente [como giros] à expressão coloquial né dessa chamada [sim, porque, mais do que uma simples pergunta, erame proferido ali um chamamento, uma conjunção já assumida sem mesmo concordar]. O recurso retórico do né, manhosamente, invocava uma intimidade anuladora como uma conformidade sobre o que já foi perguntado/suspeitado e desde o início pelo "né” já respondido. "Naquele momento, aquele eu - 'aquele' como o distante, o outro para além, o fora da filosofia - que pleiteava uma vaga diante de uma banca de direito capaz de abrir e fechar portas, aquele outro em frente à porta, realmente não poderia dançar" ${ }^{\prime 36}$.

Não seria por uma limitação ou disposição espacial-técnica, porque é bem possível dançar/proferir alguma dança em cima de uma mesa, tal como recentemente fez a obra Le cabaret discrépant ${ }^{37}$, da francesa Olívia Grandville, que ativa sobre uma mesa, como numa long-table, os 14 Petits Ballets ou Somme Chorégraphique, de Isidor Isou, escrito durante o movimento letrista francês na década 1940.

Tampouco o fato de estar numa pequena sala, para poucos, me impedia de dançar, por mais íntima e pequena que fosse a sala. Aliás, a dança contemporânea está cheia de solos de artistas que organizam suas ruínas de pensamento, gestualidades e tralharias em espaços bem pequenos, como o projeto

"prerrogativas, honras e direito" - tal como consta no diploma que agora tenho de Mestre em Filosofia. Na agoridade da anedota a que faço alusão, eu era apenas um estrangeiro - se pensarmos em títulos - Licenciado em Dança e Mestre em Artes Cênicas, o que para alguns não dizia nada e talvez não diga mesmo, nem mesmo na própria dança. Como escrevi outrora: "mesmo sendo [um] artista de formação, esse acolhimento nunca me furtou da possibilidade de ser estrangeiro a ela - essa coisa que se nomeia dança. Ser artista de dança, poder dizer-me enquanto tal, nunca me foi autorizado pelo fato de possuir um título de formação na área. $\mathrm{O}$ meu tal poderdizer na dança é também laboriosamente construído às margens da dança, por vezes sendo interditado por sua economia, estrangeiro a sua casa e tradição. Portanto, quando faço aqui essa ressalva de ser artista da dança, mesmo que de formação, ainda não me autorizo sobre ela e nem mesmo me condiciono a sua captura" (ANDRADE, 2013, p. 15). Assim são todos os títulos: papéis que evocam e carregam alguma responsividade (termo de dupla valência que afirma ética como alteridade, entre resposta e responsabilidade ao outro).

${ }^{36}$ ANDRADE, 2013b, p. 82.

${ }^{37}$ Assisti a Le Cabaret Discrépant, de Grandville, nos dias 02 e 03 de novembro de 2013, no Teatro Municipal Carlos Gomes, durante a programação do Festival Panorama 2013, no Rio de Janeiro. Um vídeo com extrato da obra pode ser acessado através deste link: $<<$ https://vimeo.com/62330252>>. Também o programa do espetáculo está disponível online em: $<<\mathrm{http}$ ///www.colline.fr/sites/default/files/documents/prog_cabaret_

discrepant_net.pdf $>>$. 
$P E B A^{38}$, que instala uma arquitetura precária e remontável em pequenas salas, cômodos de uma casa, em cima de um muro, terraços, galpões etc., confrontando quase que indiscernivelmente suas partituras com a localidade da sua performance. E, nesse sentido, eu poderia dar infinitas formas de se dançar naquela sala, mesmo estando quase-parado, ainda que aqui-depois diante do papel pudesse descrever uma orquestração entre gestualidades, papéis, cadeiras, mesa e espectros, num fetichismo de coisas dançando, teletransportando aquela situação para um sítio de dança. O mais próximo a isso, sem nunca ter escrito sobre, o fiz muitas vezes quando contando essa anedota entre os amigos, tele-coreografando a cena à distância.

Teletransportando-me outra vez para o episódio de paragem que me referia há pouco, importa lembrar que sempre recorri à imagem que mais se fixara naquela situação: um homem cabriolando as mãos, muito rapidamente, no tempo de um piscar de olhos, quando se referia à dança, como quem fizesse citação ao icônico gesto de Carmen Miranda. Mais ou menos assim o encenava: - "ele dizia 'mas aqui você não vai dançar, né?' [repetindo/ citando/ performando o tal gesto da Carmen Miranda], sem em nenhum momento ser ele mesmo Carmen Miranda nem estar diante da própria Carmen Miranda". É sempre curioso pensar sobre essa imagem que vem assombrar aquele encontro, a incorporação fantasmagórica do gesto de Carmen Miranda num piscar de olhos, no ponto cego do discurso.

A repetitividade da ausência de Carmen Miranda - não somente entre quem profere e a quem se destina, mas também na inscrição do gesto, que nele mesmo, como um código, não garante nenhuma propriedade a Carmen Miranda - é ao mesmo tempo o desvio e a força telecoreográfica que dá, ainda que forçosamente, levando-se como uma força, uma brecha ao pensamento de dança que se segue e persegue. É um escape de dança, sem ser ele mesmo uma dança ou ter a pretensão performativa de assim o ser, pois, ainda me reportando a tal episódio, não posso afirmar "rigorosamente" e "estritamente" que se tratava de um proferimento performativo de dança - uma ação direta e de direito à dança. [É importante lembrar que Austin (1990, p. 31) marca condições que definem o proferimento performativo, apontando que: "Deve existir um procedimento

\footnotetext{
${ }^{38}$ Projeto artístico entre dança, performance e arquitetura sonora que desenvolvo junto a Iara Sales e Tonlin Cheng. PEBA estreou em 2013 e se desdobrou em projeto de pesquisa continuada, seminários e livro-objeto.
} 
convencionalmente aceito, que apresente um determinado efeito convencional e que inclua o proferimento de certas palavras, por certas pessoas, e em certas circunstâncias"; e mais adiante inclui a questão do direito à intenção: “(...) aquele que participa do procedimento e o invoca [grifo aqui o invocar] deve [grifo agora o dever, a obrigação, o tributo] de fato ter tais pensamentos ou sentimentos"]. A iterabilidade $^{39}$ da citação a Carmen Miranda aqui/lá vem como uma aparição enxertada, parasitária, demandante de suporte (incorporada), portanto sem nenhuma autenticidade nem tributo, de fato, de tal intenção.

A partir desses eternos retornos, desvios e todas as traduções que tenho construído desde aí, poder-se-ia dizer que a coisa toda chamava uma dança [porvir dança]. Mas não poderia deixar de notar a paragem evocada no aqui do discurso - desde o aqui do "aqui você não vai dançar, né?" até o aqui da agoridade desta escrita encenada numa tela ou quando impressa num papel ${ }^{40}-$, pois o que me acomete ainda como questão, e talvez seja um de meus queixumes sem tom de acusação, é: podem homens da filosofia dançar? Falar sobre essa paragem do estrangeiro em frente à porta é pensar a dança? Posso estar dançando, fazendo dança, enquanto escrevo sobre ela? Quem ou quais circunstâncias determinam o poder ir direto à dança ou à filosofia ou o direito à dança e à filosofia (o poder do eu posso dançar ou posso filosofar)?

Right to Dance, Right to Philosophy - retomamos aqui elipticamente a atribuição arbitrária que intitula a segunda seção desta tese. Está lançado desde o título um certo apelo, na língua do outro, às leis que regulam (por convenção) os limites da dança, da filosofia e do direito, seja como práticas ou como disciplinas. Quem de direito e que direito se reivindicam ao se dizer bailarino ou filósofo, ao cruzar essas bordas?

\footnotetext{
${ }^{39}$ Iterabilidade é uma noção pensada por Derrida para se referir à repetição do outro. Itera em sânscrito significa outro; iterabilidade seria o movimento de repetição da singularidade como alteridade. Essa será uma noção cara ao pensamento de telecoreografia que desenvolvo nesta tese. ${ }^{40}$ Como lembra Derrida (2004, p. 223): "Mesmo quando se escreve ao computador, é ainda com vistas à impressão final em papel, quer ela aconteça, quer não. As normas e as figuras do papel mais do que as do pergaminho - se impõem à tela: a linha, a 'folha', a página, o parágrafo, as margens etc.”. Para além da problemática da impressão ou não dos textos escritos ao computador, acompanho tal pensamento derridiano quando me vejo sempre recorrendo à impressão para finalizar um texto, mesmo quando seu destino é o envio pela internet. Eu imprimo para revisar mais atentamente e assim poder enxertar outros rascunhos, desvios gráficos, canhestros de minha caneta sobre a superfície; imprimo para ter a experiência de abismo que as margens de uma folha de papel podem me dar. Posso amassar e maltratar o suporte, colocá-lo no chão ou sobre as pernas; rasgar, amassar; fazer rascunho, guardar por um tempo, acumular junto às outras coisas; posso perdê-lo em meio às outras coisas. Há um certo prazer entre a escrita e o toque. Uma corporeidade ainda que espectral toma forma.
} 
Right to (direto a/direito a) é um dos indecidíveis da desconstrução de Derrida em Du droit à la philosophie [Right to Philosophy], que reúne seu largo trabalho em diversos ensaios, conferências e seminários sobre l'enseignement philosophique, concernentes à pesquisa filosófica, ao ensino de filosofia e à relação entre filosofia e as instituições ${ }^{41}$. Tanto droit à, do francês, como right to, do inglês, podem duplamente ser traduzidos para o português como direito a e direto $a$, num só lance - e aqui se justifica, pelo menos em parte, minha decisão de abrir esta seção da tese com um título falando na língua do outro. Mas, por ora, queria apenas jogar ainda mais com um deslize arbitrário entre línguas emulando o título da tradução inglesa, Who's afraid of Philosophy - Right to Philosophy I, que encontrei por acaso durante uma peregrinação na NYU-Library. O chamado ao livro veio justamente pelo curioso título, somente atribuído à versão inglesa, "Quem tem medo da filosofia?", que num piscar de olhar me sugeriu a formulação, só para nos divertirmos: E quem tem medo da dança? Depois, num segundo momento, forçando um desvio a mais: é dado a um homem da filosofia o direito de se travestir de Carmen Miranda, ainda que espectralmente, ainda que para parar ou inquirir uma chegada de dança? Quem tem medo dessa Carmen?

[É preciso pensar seriamente sobre esse direito autoimunitário de acolher já sendo hostil nas instituições acadêmicas; direito da pura razão de sofrer do mal de soberania, comportando-se quase como um estado-nação que pode inquerir passaportes e performar paragens em frente a uma porta, a uma fronteira, mais precisamente em frente a uma mesa de juízo de homens da filosofia. Como vimos nas Marcas Preliminares, pensando o mal de arquivo de Derrida (2001), o ambiente dos homens de direito à filosofia, o falogocentrismo da tradição filosófica, é sempre marcado pela domiciliação de um privilégio topo-nomológico (o patriarcalismo). A arquiviolítica patriarcal é a fórmula pedagógica reincidente,

\footnotetext{
${ }^{41}$ Parte deste trabalho está reunido em duas publicações: Who's Afraid of Philosophy? - Right to Philosophy I e Eyes of the University - Right to Philosophy II, ambas editadas na versão inglesa pela Stanford University Press. Para os efeitos desta tese, apenas trabalharei com a primeira parte da discussão, que se refere ao problema da soberania da instituição filosófica. É também em Who's Afraid of Philosophy? - Right to Philosophy I (que na versão francesa é intitulada apenas de $D u$ Droit à la Philosophie I) que Derrida irá pensar pela primeira vez a noção de democracia por vir, inscrevendo a discussão primeiramente na filosofia, no ensino, na partilha e na participação na instituição filosófica. Tratarei mais adiante dessa questão germinal do pensamento da democracia por vir, mas antecipo, por ora, que sobre a questão da democracia no espaço filosófico é que tem se tentado escrever até aqui, desde a hospitalidade incondicional do pensar.
} 
mas nesse episódio singular não podemos deixar de notar a potencialidade queer que o travestimento espectral e telecoreográfico deixa escapar.]

Sempre que conto o episódio da espectral Carmen Miranda, ainda como uma anedota, repito aquele gesto que me veio, e ainda vem, num piscar de olhos, como um roteiro que precisa ser encenado para ativar em teletransporte aquele gesto de denegação do outro que escapou ao discurso. Nesses retornos, não pretendo criar um marco zero de tal denegação, repetindo a anedota como um gesto colonial de estereotipagem através da "fixidez" do signo, negando a ele a alteridade de seu rastro e estigmatizando-o como uma alegoria do sempre lá, no mesmo lugar ${ }^{42}$ - e outra vez estamos falando de distância). Reinvocar Carmen Miranda como uma citação iterável, uma ficção sem fixidez, demarca o problema da alteridade, sem a qual não se constituiria nenhuma metafísica, razão, nem mesmo a razão da filosofia [e, não sendo a razão exclusiva a nenhum campo de sentido, reinvocar tal gesto não direciona a resposta a nenhum deles; ou seja, não estou aqui respondendo àquele homem, mas, sim, repito, quero repetir, estou pensando como um chamamento pode fazer pensar uma dança]. Há aí uma performatividade para além da decisão intencional da ação. A invocação de Carmen Miranda pelo gesto telecoreografado vem como um código iterável, repetível para além da permanência dos sujeitos da agoridade da anedota, tal como expulso aqui nesta tela, marcando outras superfícies, salvando ainda nesta escritura o desaparecimento dos referentes daquela primeira situação.

Sobre a questão da iterabilidade da escritura, que ecoou na re-encenação dessa singular Carmen, Derrida escreve:

Dir-se-á ainda que, pela morte do destinatário, mesmo dos dois parceiros, a marca deixada por um deles será sempre uma escrita? Sim, na medida em que, regulada por um código, seja ele desconhecido e não-linguístico [podendo ser uma coreografia e também uma telecoreografia, como diremos mais adiante ], ela constitui-se, na sua identidade de marca, pela sua iterabilidade, na ausência deste ou daquele, portanto, no limite, de qualquer "sujeito" empiricamente determinado. Isso implica que não existe código - organon de iterabilidade - que seja estruturalmente secreto. A possibilidade de repetir e, portanto, identificar as marcas está implícita em qualquer código, fazendo deste uma grelha comunicável, transmissível, decifrável, iterável por um terceiro [que pode ser um terceiro momento, como o enxerto que aqui faço], depois por qualquer utente

${ }^{42}$ Cf. BHABHA, 2007. 
possível em geral. Qualquer escrita deve, portanto, para ser o que é, poder funcionar na ausência radical de qualquer destinatário empiricamente determinado em geral $^{43}$.

A iterabilidade de tal gesto pensada com Derrida tanto nos diz que, mesmo na ausência de Carmen Miranda, ela pode vir a ser invocada por uma telecoreografia e compor ali um pensamento enquanto dança [ainda que seja criando uma barreira à chegada de um pensamento de dança] como também nos diz que posso - sem nenhuma autoridade - deslocar tal gesto do que habitualmente se chamaria de seu contexto ou de sua referência originária de um episódio distante. Essa incorporação ou enxerto telecoreográfico pode tensionar, portanto, a soberania da produção de origem de um discurso, lançando ao porvir a possibilidade de se pensar que uma inscrição de dança pode acontecer para além da intencionalidade de um sujeito e sua ação. Mas, antes de falar em telecoreografia, pensemos a questão do coreográfico e sua herança singular na elaboração ocidental do pensamento da dança, marcado pela autodeterminação virtual (e poderíamos dizer também "telemático") do originário repetível.

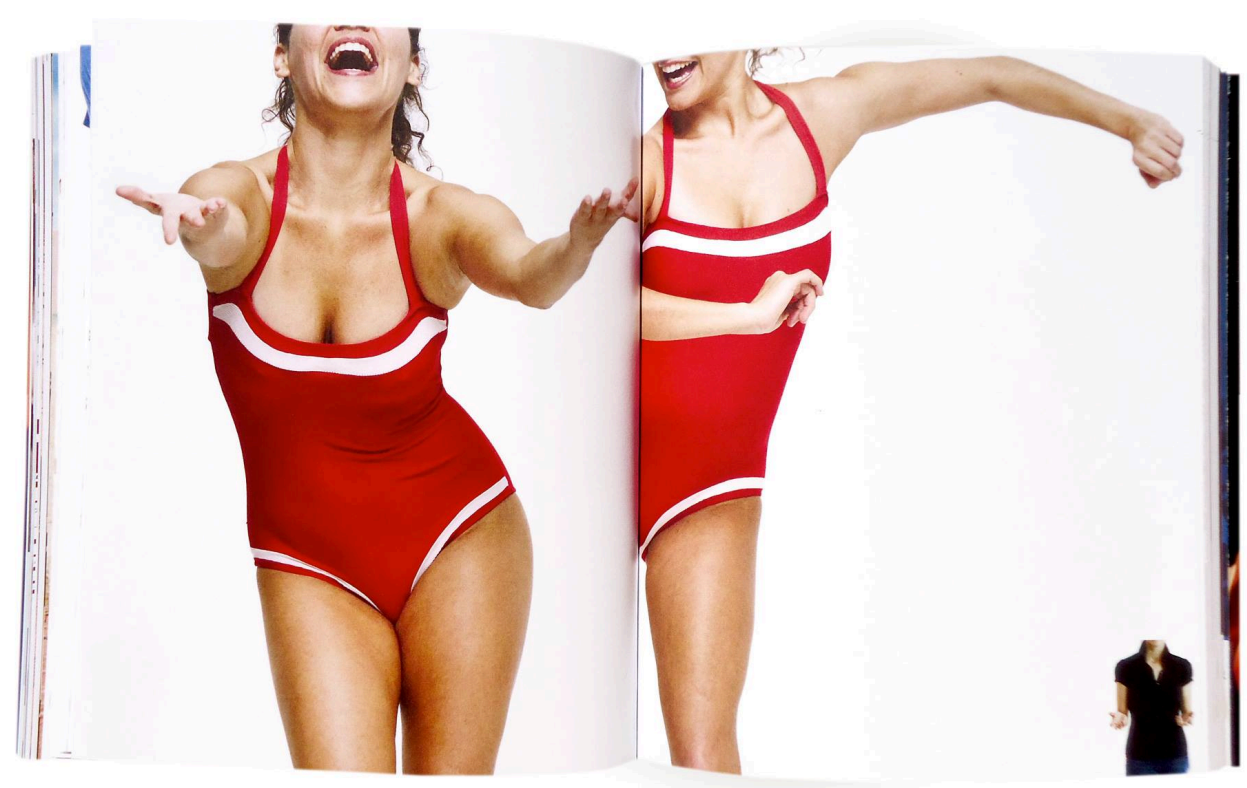

Repetição da Repetição: Carla Stank incorpora Carmen Miranda, na obra 100 Gestos, da Cia Dani Lima (RJ). Foto de Mariana Aurélio da Foto de Fábio Seixo, em Gestos - Práticas e Discursos (2013).

\footnotetext{
${ }^{43}$ DERRIDA, 1991, p. 356. [Comentários meus].
} 
Em Exhausting Dance (2006), André Lepecki ${ }^{44}$ nos mostra como a noção moderna de coreografia foi construída a partir da amarração e virtualização entre o solipsismo do bailarino e a sala vazia, que o autor nos ajuda a pensar como guias para o pensamento ocidental do being-toward-movement [ser-para-omovimento]. Segundo Lepecki, os indícios estão marcados desde Orchesographie (1589), de Thoinot Arbeau, primeiro manual coreográfico escrito no Ocidente em forma de diálogo entre dois personagens: um discípulo, Capriol (um jurista recémformado), preocupado com a permanência do legado de seu mestre de dança, o próprio Arbeau (que é um clérigo). Na leitura lepeckiana, a coreografia aparece, então, na história do Ocidente como um recurso de trabalho solipsístico para a superação da morte e da distância do mestre [que, não esqueçamos, era um padre) e para a permanência de seu legado.

Lepecki, por sua vez, nos apresentará que tal solipsismo não tem a ver somente com a espacialidade física dada pela dis-posição entre o bailarino e outros rastros que habitam uma mesma moldura, mas também, e mais radicalmente, diz respeito à esfericidade da subjetividade calculante de um certo advogado dançarino, de um certo homem de direito que dança, que, embora na reclusão de seu íntimo quarto, é capaz de engatar uma maquinaria de fazer aparecer e desaparecer corporalidades, ativando o impulso originário de uma dança, mesmo quando distante de seu mestre (o padre, o homem de deus, que é também um homem de lei, por representação ou direito teológico).

A partir da herança de Orchesographie, Lepecki, em Exhausting Dance, escreve uma fratura na relação dança e coreografia:

(...) enquanto dança é uma técnica para socializar, enquanto dança é ela mesma uma socialização, coreografia aparece como uma tecnologia solipsística para socializar com o espectro, tornando presente a força do ausente no campo do desejo masculino. Em Orchesographie, a escrita [coreográfica] tornou-se uma tecnologia de transportação, mais precisamente de tele-transportação ${ }^{45}$.

\footnotetext{
${ }^{44}$ Pensador de dança, curador e dramaturgista, professor do Departamento de Performance Studies da NYU.

${ }^{45}$ LEPECKI, 2006, p. 27. [Comentário meu].
} 
Nessa passagem, quero chamar atenção ao radical tele, em teletransportação, que remete a distante, telemático, sem fio, tensão ficcional que acompanha todo texto em seu fundo sem fundo, e mais adiante falarei dessa outra tensão entre os artigos $o$ e $a$, masculino e feminino, o desejo/o solipsismo e a escrita/a dança/a coreografia. A coreografia não somente agencia o lance de retorno ao espectro do originário (do pai, padre); ela possibilita a múltipla remitência entre coreografias, a partilha entre herdeiros telematicamente lançando-os ao porvir da iterabilidade. Para além da esfera do desejo homossocial e masculino, a telecoreografia faz a coreografia dançar na economia dos seus rastros. Lance disseminativo radical que não restitui a nenhum logos, a nenhum controle autocentrável, nem mesmo ao de um mestre ${ }^{46}$.

Ao longo de seu livro, Lepecki dá atenção à questão do tratado homossocial entre esses personagens, mas não nos fala muito sobre as especificidades desses personagens de serem, além de homens, dois homens de condutas sociais muito restritas: clérigo e jurista. Desde esses personagens, eu diria, ainda, que em Arbeau há mais de um espectro: do medo, da lei, da perda de tempo, da lamentação, dos valores de sociedade e tantos outros fantasmas próprios de cada época, de cada des-ajuste de tempo. Também não radicaliza seu pensamento sobre a telemática do coreográfico.

[Permitam-me fazer um longo enxerto aqui sobre essa especificidade do diálogo entre Arbeau (o mestre, o clérigo) e Capriol (o discípulo, o jurista), do qual outros espectros além da questão do solipsismo são emergidos entre modos de associação homossocial e heterossocial (entre os homens de lei; e entre homens e mulheres). Circulam em Orchesographie, como verdadeiras assombrações, os valores de uma sociedade bem ordenada, de sexualidade como naturalmente heterossexual, de corpo saudável e de associação entre casais pelos benefícios performados através de humores acionados pela dança. Vejamos alguns trechos desse fabuloso diálogo, ainda entre colchetes:

Capriol - Gostaria de ter adquirido a habilidade da dança durante as horas entre meus estudos sérios, uma realização que teria tornado a minha companhia bem-vinda a todos.

\footnotetext{
${ }^{46}$ E, na quinta seção, 5. No Rastro da Força Fraca, discuto também como o pensamento da telecoreografia faz tremer a relação entre materialidade e arquivo quando diante de uma dança.
} 
Arbeau - Isso vai ser uma coisa fácil de ler em livros franceses, a fim de aguçar a sua inteligência e aprender a esgrima, a dança e o tênis, o que pode lhe fazer um companheiro agradável tanto para senhoras quanto para senhores.

Capriol - Eu muito apreciei a esgrima e o tênis, e isso me tornou amigável entre os homens jovens. Mas, sem o conhecimento de dança, eu não poderia agradar as donzelas, das quais parece-me depender toda a reputação de um jovem elegível.

Arbeau - Você tem toda a razão. Tão naturalmente o macho e a fêmea procuram um ao outro, e nada estimula mais um homem aos atos de cortesia, honra e generosidade que o amor. E, se você deseja se casar, deve perceber que uma amante é conquistada pelo bom humor e graça exibidos enquanto dança, porque as senhoras não gostam de estar presentes em esgrimas ou tênis, para que um estilhaço de espada ou um golpe de uma bola de tênis não lhes cause ferimentos. [...] o dançar nos serve para revelar se os amantes estão em boa saúde e boa forma [sound of limb], assim que eles estão permitidos a beijar seus amantes, para que eles possam tocar e saborear um ao outro; assim, podem verificar se eles estão em forma ou se emitem um odor desagradável, como de carne podre. Portanto, a partir deste ponto de vista, muito além das muitas outras vantagens derivadas da dança, ela torna-se um elemento essencial em uma sociedade bem ordenada ${ }^{47}$.

Mais adiante, os espectros éticos e pedagógicos de Arbeau ficam ainda mais claros, como também a estrutura coreográfica se formula assombrada pelo desejo e pela interrupção, com ares de libertação, recalque e prazer. (Já não podemos pensar essa arquetípica cena sem ecoar as obscenas figuras de impressão freudiana de que nos fala Derrida, em Mal de Arquivo $(2001)^{48}$ ). Sem mais giros, voltemos ao diálogo de Arbeau e Capriol:

\footnotetext{
${ }^{47}$ ARBEAU, 2011, pp. 11-12. [Tradução minha; grifos meus].

${ }^{48}$ Uma Impressão Freudiana é o subtítulo de Mal de Arquivo (2001). Derrida escreve sobre a questão do arquivo tributando sua leitura às impressões deixadas por Freud. Uma passagem condensa ao menos três sentidos que a palavra impressão com Freud imprime em Derrida: “(...) três sentidos da palavra 'impressão' só puderam se imprimir em mim, de um só golpe, num instante aparentemente sem duração, a partir de um longo trabalho tão descontínuo quanto possível, junto ao texto de Freud, de alguns de seus escritos, mas também de temas, figuras, de esquemas conceituais que me são familiares a ponto de se constituírem numa obsessão, e nem por isso menos secretos, novos e ainda por se revelar para mim: a escritura, o rastro, a inscrição sobre um suporte exterior ou sobre o corpo chamado próprio, como, por exemplo, e para mim este não é um exemplo qualquer, este arquivo singular e imemorável que chamamos circuncisão e que, para não mais deixar vocês, não é menos sobreposto e exterior, diretamente exterior ao próprio corpo de vocês" (DERRIDA, 2001a, p. 40). Mais adiante, Derrida ainda enumera as impressões marcadas por Freud: 1. a impressão escritural ou tipográfica - que tanto diz respeito ao problema do suporte, da impressão sensível e da cópia que "desempenham um papel capital na genealogia das ideias" (idem., p. 42) como também diz respeito aos deslizes de tradução que impressão recorda
} 
Capriol - (...) Não me atormente mais atrasando em conceder o meu pedido de aprender como os movimentos da dança são realizados, a fim de que eu possa dominá-los [in order that I may master] e não ser repreendido por ter o coração de um porco e a cabeça de um jumento [notemos o medo e também o recalque marcado na metamorfose animal-homem do corpo], como Lucian fez com Craton.

Arbeau - Lucian não reprimiu aqueles que não tinham vontade de dançar ou aqueles que desejavam, mas, sim, aqueles que eram incapazes de aprender a arte; aqueles que a condenaram e que aspiraram a abolir a dança como uma prática do mal sem refletir que as danças são de dois tipos. Uma delas é empregada na guerra para a força e a defesa do Estado; a outra é recreativa e tem a virtude de atrair corações e despertar o amor. É um preliminar e, como eu já lhe disse, um dispositivo útil para descobrir se uma pessoa é deformada por gota ou ainda defeituosa dos membros. Também se elas são formosas e modestas. Lemos que Clistenes, tendo visto Hippoclides dançando e vangloriando-se de forma imprudente, recusou-lhe sua filha em casamento, dizendo que ele tinha dançado seu casamento fora [danced his wedding away - que expressão curiosa!].

Capriol - Graças a Deus, eu não tenho tais enfermidades, apenas uma irmã de doze anos de idade, quem eu irei instruir assim que você me ensine. ${ }^{49}$

Essas passagens de Orchesographie (1589) telecoreografam múltiplos espectros que engendram o início do tratado coreográfico ocidental como um aprender a viver, como um certo modo de "bem viver" o social, dançando uma certa dança bem orientada e bem ritmada. A dança que se cerca aí está assombrada pela repreensão da vida social e das suas marcas imprimidas no corpo, pelos valores de saúde e de enfermidade próprios do seu tempo. Não podemos deixar de notar que a evocação de Arbeau ao aparelho do Estado imprime também uma outra espectrologia de seu tempo histórico, justamente ali no século XVI francês, quando e onde se desenhavam os limites geopolíticos do

junto a Verdrängung [repressão] e a Unterdrückung [supressão] -, pressões de forças suplementares à noção/impressão de recalque; 2. o valor desta palavra impressão que esvazia a noção de conceito: "não temos conceito, apenas uma impressão, uma série de impressões associadas a essa palavra" (idem., p. 43); 3. "impressão freudiana" ainda quer dizer a "impressão deixada por Sigmund Freud, a partir da impressão deixada nele, inscrita nele” (idem, p. 45), o trabalho em marcha do espectro de Freud e seus suplementos; a arqui-escritura que chamamos Freud está "inscrita nele a partir de seu nascimento e sua aliança, a partir de sua circuncisão, através da história, manifesta ou secreta, da psicanálise, da instituição e das obras, passando pela correspondência pública ou particular" (idem, p. 45).

${ }^{49}$ Idem, pp. 17-18. [Tradução minha; comentários e grifos meus]. 
governo soberano como Estado-nação. Na tele-transportação [para usar um termo lepeckiano] histórica da coreografia para o domínio metafísico, nos dias de hoje, a força e a defesa ativadas pela reiteração de um gesto de dança excederiam os limites da noção tradicional de Estado, mantendo alguma afinidade (talvez telepática) com essa forma de espacialização e de controle, de autodefesa e de autoimunização [lembremos outra vez o episódio em frente à mesa, a chegada de uma certa dança às margens do espaço filosófico].

A dança no rastro social, ensinada/coreografada a partir de um diálogo, ordenada numa estrutura bidimensional de papel, para ser publicada, reproduzida, difundida e repartida pelos herdeiros bem formados, reitera a economia arquiviolítica no corpo dançante. Arrastando para a discussão o problema do arquivo pensado por Derrida (2001), poderíamos dizer que o manual coreográfico de Arbeau imprime e arquiva na dança a força da lei. Aquele que dança uma coreografia, que recebe a herança de seu mestre e pode partilhá-la repetidamente entre os seus o faz já sob o medo do recalque e do recalcado [lembremos: aqueles que sofrem de gota ou alguma doença nos membros - que cena mais recalcada! - ou que se vangloriam imprudentemente não passarão despercebidos]. O fabuloso diálogo coreográfico de Arbeau imprime na dança o espectro da heteronormatividade neutralizada e pedagógica como saúde do corpus social - e a repartição entre guerra e recreação não são casuais nesse diálogo, como também não é por acaso que esse diálogo seja desenhado entre um clérigo e um jurista].

No episódio da espectral-Carmen em que tenho me demorado aqui como cena de dança [sem teatro, sem ser num teatro], a inscrição da dança é anunciada como um desvio, a chegada do outro que pode vir a desorganizar uma casa, um habitar, desenhar sem desígnio, sem lei própria... uma força fraca [e retornarei em instantes a essa singularidade]. A dança que vem vem sem lei própria, precisa ser parada, desviada pelo outro, e assim ganha força ainda que fraca. Chega como uma queda (na queda de pálpebras do "piscar dos olhos", num "ponto cego") e chama o pensamento para baixo. Nesse hiato antes e depois do ver, mas também anacrônico ao ver, a coisa vem como um acontecimento de dança, se aproxima sem se deixar ver vindo. Como responder a esse pensamento que me vem como 
experiência, experiência do que (de quem) vem, do acontecimento, de um acontecimento que cai em cima, que cai em cima de nós sem prevenir e sem que o vejamos vir? $?^{50}$

Por um lado, a telecoreografia que, em diferentes tempos, insisti muitas vezes em reportar tensiona uma proximidade/distância ao pensamento de Lepecki quanto à questão da soberania do originário no dispositivo coreográfico. Lepecki afirma que, "coreografia torna-se o que permite um jurista [a lawyer - homem de lei e de direito] intimar, citar, repetir os gestos fundacionais, o presente ausente e a cadência da força originária de uma dança" ${ }^{51}$. Lepecki posiciona, assim, a coreografia como um dispositivo de lei, análogo a um tipo de aparelho ou máquina de direito, que dá acesso - guia, caminho - justamente ao core originário dançante, que, desde a herança de Arbeau, é engendrado no campo do desejo masculino num ambiente domiciliar. "O leitor-dançarino [advogado] pode estar sozinho no seu quarto, mas, graças ao livro coreográfico, ele está sempre pronto para invocar e dançar com aquele que não está mais lá, aquele que já se foi" ${ }^{\prime 52}$. Nessa leitura, o desejo de participação, de partilha e de passagem da dança através do teletransporte coreográfico reencena, ao mesmo tempo, a topoeconomia arcôntica e o problema da iterabilidade telemática da escritura que marca a tradição coreográfica do pensamento de dança.

O poder do eu posso dado ao sujeito-coreográfico, acompanhado do falogocentrismo ocidental nas mais diferentes épocas, na chamada "dança cênica ocidental", sempre delineou a experiência limite do labor do corpo que dança e, portanto, de quem pode dançar: o direito à dança e o passaporte direto à dança (o duplo right to dance). A partir da contribuição atravessada entre Lepecki e Arbeau, é possível ainda pensar como a noção de coreografia tem se apresentado como um dispositivo de comando e obediência, de guarda e de partilha, mantenedor e mediador da soberania do originário solipsístico (e também assombrado) na dança: seja ela para “atrair os corações e despertar o amor”, seja ela para proporcionar "a força e a defesa do Estado" [se pensarmos na fratura social originária de Arbeau que nos permite agora abrir janelas para algumas discussões por vir nesta tese]. Nesses termos, pensar coreografias nos permite

\footnotetext{
${ }^{50}$ Estou aqui reimprimindo palavras de Derrida como se fossem minhas; reimprimindo suas impressões com alguma modificação. $C f$. DERRIDA, 2012, p. 75.

${ }^{51}$ LEPECKI, 2006, p. 27.

${ }^{52}$ Idem, p. 33.
} 
refletir sobre as tecnologias performativas a serviço dos homens de lei - dignos de tal, podendo revezar-se nesse papel o bailarino e o coreógrafo, o mestre e o discípulo, o pai e os herdeiros, o sêmen e o disseminal - capazes de solicitar e pôr em prática uma lei, a serviço da própria lei como uma força de lei do uno, solipsístico, que reúne um certo tipo de liga, de destino da coreografia como estado coreográfico, uma coisa coreografada.

Lepecki afirma, com efeito, que o solipsismo,

(...) quando entendido como uma metodologia filosófica que implica a força poética da linguagem direta ao core do mundo [language right at the core of the world, diz Lepecki em inglês, que poderia também ser traduzido com sentido de justeza, justo ao core do mundo - right at the core of the world; justamente aí no mundo, quase que i-mediata justeza ao mundo], torna-se um meio para transcender o being-toward-movement moderno auto-reservado, socialmente cortado, automotriz" ${ }^{\prime 53}$.

É através desse desejo solipsístico que homens-de-lei-da-dança se inserem no projeto ontológico-filosófico, que para Lepecki parece incondicional, quando arremata mais adiante: "sem individuação, não há possibilidade de atribuição subjetiva nas economias de lei, nomeação e significação" ${ }^{54}$.

Por outro lado, a ontocoreografia de Lepecki, o desejo de ir diretamente/justamente ao core do mundo, como uma língua direta reserva, ou ainda arquiva, um mono-tonismo de vozes em nome do solipsismo. Lepecki, como um scholar, está comprometido com a afirmação do coreográfico como um método filosófico e, assim, não observa o risco que essa positivação enclausura e reencena. É nesse momento que preciso arriscar uma marca de distância minha em relação à contribuição de Lepecki, reconhecendo a tensão necessária desse gesto. O pensamento telecoreográfico que venho elaborando aqui não é, nem pode ser, um método solipsístico.

$\mathrm{O}$ right at core da ontocoreografia de Lepecki mantém em alguma medida uma continuidade entre a ausência e a presença da lei do logos pela coreografia - como método. Esse right at core é estrategicamente oportuno, nos permite atravessar fronteiras, participar de uma certa tradição filosófica, mas precisa ser colocado sob rasura, imprimindo nele um gesto de suspensão de seu

\footnotetext{
${ }^{53}$ LEPECKI, 2006, p. 40. [Comentários meus]

${ }^{54}$ Ibid., p. 44.
} 
rastro: right at core, para seguir pensando coreografias, telecoreograficamente, sem atribuir a elas a restituição ao logos, ao originário, ao core. A desconstrução do falogocentrismo, sua espacialização, resiste - precisa resistir - à soberania do uno indivisível.

Seguir telecoreografias para pensar o acontecimento da dança que foge ao horizonte, portanto, nunca pode nos conduzir a um movimento direto e de puro direito. As telecoreografias não estão plenamente diante de nós, à nossa disposição e, como pensei com o espectro-Carmen, podem até acontecer na penumbra, num instante do piscar de olhos. A noção de right at coreográfico de Lepecki é condicionada, tanto quanto os múltiplos desvios que precisei aqui telecoreografar para dar a pensar uma dança de obliteração radical, fazer a coreografia dançar, dançá-la para fora [dance ontocoreography away!]. Assim, a fratura dança/coreografia, ainda que útil e importante, parece sofrer um abalo, pois já não se pode falar mais de origem nem de caminho direto ou de direito à linguagem - nem mesmo à linguagem coreográfica. A dança que re-encenei aqui não parece seguir o mesmo caminho direto/justo, apesar de estar junto, ainda sem fazer parte.

O risco assumido aqui, de tentar manter certa distância, quer inscrever a incerteza desse gesto, para não soar que essa distância apontaria em Lepecki um erro ou equívoco no seu projeto (e seria um projeto?) de defender uma ontologia na dança, mesmo que somente como um título introdutório como o de $A$ Ontologia Política do Movimento ${ }^{55}$. Não seria essa distância a que me refiro. É preciso dizer, assertivamente, como uma missiva, se possível, que esse risco que aqui assumo é desde já uma hospitalidade, um acolhimento radical marcado pelo right at core de Lepecki (que li muito mais em inglês do que em nosso português e, portanto, o risco de que falo é também, declaradamente, um risco de tradução, de um certo desvio de tradução ou de má tradução), investindo um pouco mais no deslize desse radical latino - core - que transita entre coração, cerne, centro e também em coreográfico.

É somente já assumindo essa marca que posso de alguma forma direta, mas também desviante, falar de coreografias e telecoreografias [que, a rigor, são a mesma coisa sem ser mesmo uma coisa indivisível]: pelas palavras do outro, em

\footnotetext{
${ }^{55}$ Me refiro ao título atribuído à introdução de Exhausting Dance (2006).
} 
outra língua, com Lepecki, mas também com Arbeau. É nesse tele-core, arriscando-me numa certa distância, que já quase sei quase-de-cor, que a tenho também como minha, sem jamais possuí-la - uma gratidão às outras impressões das escritas de Derrida. Essa gratidão é como pensamento por vir, o trabalho do pensamento sempre por vir, que para o autor é, sobretudo, um dom, mas também uma dação, uma oferenda "que me dá mais do que aquilo que eu poderia alguma vez possuir. Porque me dais muito mais do que eu posso ter e apropriar. Recebo mais do que eu posso ou devo receber" ${ }^{25}$.

Arriscar uma distância aqui é assumir esse dom que em nada se assemelha ao privilégio, à autoridade, nem à autorização sobre. Arrisco manter uma certa distância, mantendo e assumindo a sua incorporação. E, outra vez, incorporo, também em risco, palavras de Derrida:

(...) este dom - sabei-o - me vai direto ao coração. Vai direto ao coração daquilo $a$ que me apego, ao coração daquilo pelo qual me apego, aí onde o trabalho do pensamento e da escrita subsiste ainda em mim, me sustém, me sustém em vida $[e$ sublinharia esse duplo sustém, para marcar a questão da suplementaridade; eu-Sérgio, já um suplemento dessa escrita], e é por isso que eu faço questão em falar do coração, do fundo do meu coração ${ }^{57}$.

O (nosso) português reserva na palavra obrigado algo desse arriscado gesto. Aprendi por uma disseminação muito ampla que o performativo obrigado, que se diz em resposta de agradecimento a um gesto, seria uma elipse de sinto-me obrigado a retribuir. Esse performativo, portanto, como uma elipse reserva um segredo de abrigar, o acolhimento, o amparo que se deixa ecoar ao dizer obrigado. Sente-se a dívida acolhida de dentro e já oferecendo-a como retribuição. De coração. Sinto-me obrigado a agradecer e, então, retribuindo o gesto de pensamento, seguir pensando.

Pensar a desconstrução na maneira como a dança se inscreve não como na experiência de uma vinda no horizonte, que por ora, ainda que provisoriamente, chamei de telecoreografia ou teleperformance coreográfica, é pensá-la para além do atendimento do projeto ontológico ocidentalizante masculino/soberano [e diria que o trabalho de Lepecki, de uma outra forma,

\footnotetext{
${ }^{56}$ DERRIDA, 2009c, p. 42.

${ }^{57}$ Idem. [Os comentários entre colchetes são meus; os grifos de Derrida]
} 
também quer pensar essa desconstrução também ${ }^{58}$ ]. A teleperformance coreográfica parece estar à mão dos homens de lei, ao mesmo tempo que lhes escapa e está fora da lei. É somente nessa temeridade de fugir da lei que se pode falar de uma obediência à lei ou de uma quebra da lei. Há uma exterioridade desde o gesto de disseminação da lei. A dança pode ser chamada, invocada, encetar uma coreografia, mas ela ameaça escapar, interceptar o fluxo, impossibilitar a comunicação, trair subjetilicamente no seu rastro, na sua escrita, na sua maneira de se inscrever e se imprimir como experiência. Pode-se dançar uma telecoreografia estando fora da lei, como um/a dançarino/a dança uma coreografia sem nem mesmo anunciar-se como tal.

O espectro de Carmen Miranda, tele-incorporado aqui/lá, como já vimos, não pode ser legitimado por nenhuma lei em si, não pode dar acesso direto, nem de direito, à dança ou à filosofia, nem nos lança direto a Carmen Miranda ou aos atores participantes ou às circunstâncias daquele evento espectral e também queer do chamamento entre mãos e piscadas. Dá-se aí uma força fraca ${ }^{59}$ que não reivindica nenhum estado de direito, mas ao mesmo tempo pode fazer tremer os limites de um estado de direito, os quais só ganham sentido e força quando iteravelmente atritado com o outro. É preciso incorporar a Carmen Miranda para também expulsá-la: atração, apelo e evitação do outro a DisTanz.

\section{1.}

Filosofia e Democracia Por Vir: Sim ao Pensar! De Que Direito-Direto?

Há pouco lancei algumas perguntas sobre o direito de a filosofia pensar com a dança ou ainda o direito de incorporação da filosofia, a incorporação de um gesto, de uma mulher e também de uma assinatura, de uma certa Carmen Miranda - da Carmen Miranda como um gesto, como uma assinatura -; se poderia um homem de direito à filosofia incorporar tal gesto, tal como se dança

\footnotetext{
${ }^{58}$ Lepecki escreveu sobre a relação entre o feminino e a noção de coreografia em outro lugar, que não pude tratar aqui para não causar um desvio muito grande nesta tese. No entanto, permitam-me deixar registrada uma referência em que o autor trabalha essa discussão: LEPECKI, A. Inscribing Dance. In: LEPECKI, A. (ed.). Of The Presence Of The Body: essays on Dance and Performance Theory. Middletown: Wesleyan Press, 2004.

${ }^{59}$ Retomarei a questão dessa força mais adiante.
} 
uma coreografia, para barrar a chegada de um estrangeiro à filosofia. Essa elaboração seria desrespeitosa, digo, não diria respeito a um homem da filosofia? Pode a filosofia dançar? É de direito de um homem da filosofia, dançar? Ou ainda, é de direito fazer filosofia com dança ou dança com filosofia? Bastaria irmos direto ao direito (seriam questões do direito?) para pensarmos o direito à filosofia e o direito à dança? Ou essas seriam questões pertencentes à filosofia-mesma ou à dança-mesma? Precisarei me demorar um pouco nessa discussão.

Para tanto é preciso retomar a questão do "right to/droit à" outra vez. Esse indecidível em outra língua que arrisquei traduzir como direito-direto, num mesmo lance. A questão do título, do lance que se lança num título, urge aqui. É preciso pensar sobre a experiência do título de reunir e lançar, "encabeçar um texto". Diz-se que um título "encabeça um texto" como quem chama cabeça aquilo que vem primeiro no corpo, como um guia. Não podemos deixar de notar desde aí uma hierarquização das partes do corpo, que se esquece da condição do ser-corpo da cabeça e diz que a experiência do todo é uma soma de "corpo e cabeça". O intitular marca, assim, uma certa ordem de leitura, de cima para baixo, ou ainda de uma certa experiência total da leitura, como se diz "da cabeça-aospés". Porém, é preciso, talvez, de início, se perguntar sobre que direito dá ao título o direito de levar, de guiar, de marcar o início como guia, de um texto. De que direito advém tal movimento, da cabeça-aos-pés? Quem pode inquirir tal movimento? É preciso, ainda, perguntar sobre essa promessa de início sem poderse reclamar do que se arquiva nessa lei do título, do intitular, essa promessa como uma promessa de performativo quase-absoluto que, como tal, guarda seu segredo de lei, disfarçado no simples declarar explicitamente o que se diz, enunciando um proferimento, um título, como um direito. É esse título “de direito", já dado numa rede de rastros impossíveis de recontar, que aqui reitero a questionar.

Austin, em suas primeiras notas de rodapé ${ }^{60}$, em How to Do Things with Words? (1962) — na versão traduzida para o português, por Danilo Marcondes: Quando o Dizer É Fazer (1990), título que, ao menos para mim, numa tradução ainda mais desviante, ecoa no título desta tese —, nos diz: "Era de se esperar que os juristas, mais que ninguém, se apercebessem do verdadeiro estado de coisas.

\footnotetext{
${ }^{60}$ Logo num segundo texto, no rodapé, abaixo daquilo que chamamos corpo do texto e que o acompanha, por vezes ao fim de todo o texto, como uma segunda parte ou seção, um suplemento inserido depois, atrasado.
} 
Talvez alguns agora já se apercebam. Contudo, tendem a sucumbir à sua própria ficção temerosa de que uma declaração 'de direito' é uma declaração de fato" ${ }^{\prime 61}$.

Desde aí, está lançada a questão de direito que estou tentando reencenar, dizer em outras palavras. A declaração de um direito excede a questão do título e, como deixa escapar Austin, também não é um privilégio dos juristas — aqueles que, de direito, pelo título que evocam, guardam por autorização e autoridade o uso do direito. Um título, por sua lei, que se mantém em segredo, mesmo que explicitamente declarado, também pode desviar; ele por si, na condição de um nome, não reserva nenhum direito nem sentido fora do exercício de se manter agindo como tal. Um título age, tal como um nome, e assim o faz, se exerce como tal, assombrado pela sua própria ficção de destinação, que pode não ser cumprida; mas ele promete, age como promessa.

Retornemos ao título e subtítulo desta seção e subseção, "Right to Philosophy, Right to Dance... assim mesmo, na língua do outro" e "De que direito-direto?", que respondem um ao outro ainda que em pergunta. Não é qualquer título, como nenhum título o é. Joga na língua do outro, promete explicitamente esse jogo, sem por tal condição - de se dar às luzes do olhos encerrá-lo. Que seria esse performativo, desde o título, de falar na língua do outro? De que direito? Ou ainda, de que direito-direto se pode dizer-fazer tal promessa? De partida, observemos na marca e na obliteração desse hífen a provocação que deixa ecoar múltiplas perguntas: se é possível ir, de direito, direto à filosofia mesma sem nos cansarmos nesses desvios todos de percurso, nesses rodopios, cheios de anedotas e fantasmagorias; ou a que ou a quem de direito se poderá atribuir ou privar quem ou que da filosofia; ou ainda se alguém ou algo é digno de ser-filósofo ou ser-filosófico. No hífen de "direito-direto", abre-se uma brecha para pensarmos a questão da pressuposição institucional da filosofia, que regula de alguma maneira o movimento em direção à filosofia, seja direto ou de direito.

Como antecipei acima, em Who's Afraid of Philosophy? - Right to Philosophy $I^{62}$ (2002), Derrida inaugura a discussão da democracia por vir debatendo como o direito à filosofia é fundado no direito a um privilégio de

\footnotetext{
${ }^{61}$ AUSTIN, 1990, p. 23, nota 3. [Os grifos são meus].

${ }^{62}$ Irei seguir a tradução inglesa para manter a discussão desde a origem na língua do outro e também para destacar a questão do título Who's Afraid of Philosophy?.
} 
participação da filosofia e sua herança, tal como opera a autodeterminação da soberania de um Estado ${ }^{63}$. Esse privilégio é também um tema da filosofia: o privilégio filosófico - título da primeira parte da discussão derridiana: Privilege: Justificatory Tittle and Introductory Remarks [O Privilégio: Título Justificativo e Observações Introdutórias]. Seguirei um pouco desse gesto agora.

Logo nas suas primeiras páginas, Derrida estabelece o trato da discussão, indo direto à questão:

Se eu disser, por exemplo, e esse é o primeiro sentido do meu título, "Como se faz para ir direto à filosofia?", nos envolveremos em uma certa problemática. Será um assunto, por exemplo, das relações que permitem ir do pensamento jurídico, da prática ou da disciplina jurídica, para a filosofia e a questão de quid juris que há muito tem trabalhado em seu âmago. Será uma questão, mais precisamente, da relação da estrutura jurídica que implícita ou explicitamente apoia a instituição filosófica (ensino e pesquisa) com a filosofia ela-mesma, se tal coisa existe fora, antes ou além de uma instituição. No seu primeiro sentido, o título Right to Philosophy anuncia um programa, uma problemática e um contrato: trataremos das relações entre direito e filosofia. Além disso, todo contrato implica uma questão de direito. E um título é sempre um contrato. De modo que, no único caso da filosofia, este contrato é destinado a mais de um paradoxo, que é este nosso tema privilegiado, o privilégio como nosso tema ${ }^{64}$.

A questão do privilégio é anunciada no título atribuído por Derrida, $D u$ droit à la Philosophie /Right to Philosophy, jogando com a pequena letra à, em francês [na tradução inglesa, o pequeno to] que carrega uma determinação semântica, ao mesmo tempo em que articula duas áreas - o direito e a filosofia. Tal articulação possibilitará Derrida pensar a questão de lei do filosófico a partir do privilégio de endereçamento da filosofia à instituição filosófica - esta última que para o autor, como vimos, vacila em ser a filosofia mesma: nem fora, nem antes, nem além dela mesma.

Antes de partirmos para a discussão adverbial, do movimento de ida à filosofia, vamos pensar a questão substantiva do direito: ter um nome, ou melhor, um título de direito à filosofia. "Ter o 'direito à filosofia' é ter um acesso legítimo ou legal a alguma coisa cuja singularidade, identidade e generalidade continuam

\footnotetext{
${ }^{63}$ Nessa relação entre pressuposição institucional e a noção de Estado, Derrida abre uma porta para se pensar a questão da soberania para além da definição de Estado-nação. A noção de soberania em Derrida é análoga ao sentido de ipseidade como poder de autodeterminação.

${ }^{64}$ DERRIDA, 2002, p. 2. [Todas as traduções são minhas.]
} 
tão problemáticas como o que é chamado de Filosofia [la philosophie]"65, nos diz Derrida. Por um lado, é da filosofia mesma um certo direito ao privilégio filosófico de atribuir uma questão desde um título, nomear um problema que encabeça um texto. Por outro lado, é também o privilégio da filosofia dar um título como uma habilitação, um direito de filosofia. Em ambos os casos, para Derrida, os títulos são sempre dados por alguma instituição, seja ela formada por uma ou mais de uma pessoa.

Titular é uma ação ou mesmo uma dação advinda de um certo privilégio constituído alhures: só se pode dar um título estando dentro de uma certa linguagem, dentro de um certo poder dizer ao outro, portanto, dotado de ato de fala - é o que nos diz Derrida (2002). Tal gesto necessita, porém, da predisposição instituída e recebida outrora por uma herança de um direito também recebido por outro ato de titular. Essa repetição do dar e receber títulos a partir de uma acúmulo vindo do outro e enviado ao outro não se fenomenaliza no acontecimento mesmo da dação do título mas é a lei do título. Fazemos coisas com as palavras/títulos, que damos ou que recusamos, já sendo portanto intitulados para tal, participando de um certo pressuposto institucional (um corpo, uma reunião ou um estado que dá títulos) formado pelo jogo da alteridade. As palavras/títulos fazem coisas na sua iterabilidade, na sua re-encenação de origem como uma repetição de dação.

É a partir dessa iterabilidade não aparente que Derrida irá nos lembrar da singular violência performada pelo título. Cito:

\begin{abstract}
A origem do poder titular ou creditar pode assim nunca ser fenomenalizada como tal. A lei de sua estrutura - ou a estrutura de sua lei - depende de que essa condição desapareça. Isso não é meramente um círculo. O pensamento de um tal "círculo" pelo menos força a reformar a imensa questão que está já "classificada" sob os títulos de "repressão", "supressão" ou "sacrifício" 66 .
\end{abstract}

A não fenomenalização da lei que faz circular a economia de legitimação ou legalização de títulos deve desaparecer. O poder de titular só se efetiva por uma lei que não pode ser rastreada na sua origem, eis o paradoxo da pressuposição institucional marcado por Derrida. É a partir desse paradoxo, e reformando a questão da "repressão", "supressão" e "sacrifício" na filosofia, que

\footnotetext{
${ }^{65}$ Idem, p. 3.

${ }^{66}$ Idem, p. 5.
} 
Derrida recoloca a questão do direito à filosofia e sua lei que não pode deixar aparecer o fundo sem fundo em que ela está fundada.

Tal tópico, segue Derrida, afeta a estrutura da instituição filosófica como arquivo: "uma instituição guarda na memória, certamente, ela é feita para isso", porém,

\begin{abstract}
Ela pode, antes de tudo, esquecer seu próprio eleito: sabemos que a instituição por vezes perde seus nomes em profundidades cada vez mais inacessíveis. Essa seletividade sem dúvida significa, antes de tudo, a finitude de uma memória institucional. Este paradoxo repousa em outro lugar, contudo, mesmo se for também o efeito de uma essencial finitude: o que chamamos de uma instituição deve às vezes lembrar o que ela exclui e seletivamente tenta condenar a ser esquecido. A superfície de seu arquivo é marcada então pelo que continua fora, pelo que expele ou não tolera. Toma a forma inversa do que é rejeitado. Deixa-se ser delineada pela própria coisa que a ameaça ou aquilo que parece ser uma ameaça. $\mathrm{Na}$ ordem de identificar a si mesmo, de ser o que é, delimitar a si e reconhecer a si em seu próprio nome, ela deve defender os próprios contornos de seu adversário, se eu puder colocá-lo assim. Ela deve usar as marcas de seu adversário, até mesmo ter seu nome como marca negativa. E a coisa excluída, cujos traços são profundamente gravados na cavidade do arquivo, impressos diretos no suporte ou na superfície institucional, pode acabar, por sua vez, tornando-se a memória do corpo institucional. Essa é a verdade fundante da violência de estado e nações e que as pessoas não desistem de suprimir ou destruir. E isso nunca ocorrerá de uma vez por todas, mas deve necessariamente continuar ou repetir-se de acordo com diversos processos e ritmos $^{67}$.
\end{abstract}

A reabertura da discussão da atribuição de títulos e sua lei que age sem aparecer diz que os processos de esquecimento e exclusão não somente são fundantes de qualquer instituição, como também deveriam ser, para Derrida, um chamado a qualquer instituição. A seletividade entre lembrar e esquecer é a estrutura sacrificial de qualquer instituição: constrói a superfície institucional e divide o espaço-tempo da instituição, na cavidade de seu arquivo. Tal violência, nos diz Derrida, é a mesma de um estado-político que nas suas fronteiras aceita e renega o título de cidadão, seletivamente, criando critérios de importância para ser lembrado ou esquecido pelo Estado. Essa é uma lei que também precisa desaparecer no estado-político; caso não, põe-se em risco a própria estrutura do

\footnotetext{
${ }^{67}$ Idem.
} 
Estado, seu direito de ser Estado, sua soberania como tal. Afinal, é do soberano cassar, seletivamente, certas liberdades individuais em nome de sua liberdade autodeterminada de ser soberano.

Claro que a instituição acadêmica - e a filosofia, em particular - está em uma escala mais modesta, e Derrida também faz essa ponderação. No entanto, tal aproximação entre estado-político e instituição acadêmica reacende o problema de se pensar a questão dos limites do espaço filosófico, da construção de suas fronteiras dentro do jogo de apagamento de suas fronteiras. Uma questão de poder. Quer dizer, sob o título da filosofia, a estrutura sacrificial é fundante para construção de leis, procedimentos, rituais e passaportes próprios da participação no espaço filosófico; próprios como de uma propriedade, "uma parte de um todo", "um solo", "um terreno" por onde se pode circular seletivamente determinados sujeitos.

Nesse terreno, abrem-se elaborações, talvez, mais exorbitantes, como a questão da democracia no espaço filosófico. Afinal, pode-se perguntar: a filosofia opera um espaço democrático? Está-se no terreno da filosofia quando se profere tal questionamento? Que se pretende com essa discussão? Essa pergunta é digna de objeto filosófico? É de direito? Quem de direito poderia vir até um certo nós e perguntar-nos sobre a questão da democracia no espaço filosófico? Antes de pensarmos se há pertinência para tais indagações, precisaríamos recorrer à questão “que é a filosofia?”? Retornar à questão do espaço, ou da unidade, em que a filosofia possa identificar-se consigo mesma, reinstaura a estrutura sacrificial ou de supressão ou de repressão do outro não filosófico? E mais: A experiência da pergunta "que é a filosofia?" é já uma experiência filosófica? Participa-se, democraticamente ${ }^{68}$, do espaço filosófico quando se caminha numa tal experiência?

Essas perguntas podem nos levar a uma experiência além ou aquém da filosofia. Poderíamos refletir nessa experiência de margem, aquém ou além, antes ou depois da filosofia, para se pensar como a questão do direito à filosofia,

\footnotetext{
${ }^{68}$ A democracia tem sido repetidamente invocada. Desde o episódio em frente à banca de homens da filosofia, que, de direito, barraram a entrada da dança-sem-explicações, fica marcado então o meu interesse pela discussão que está se seguindo sobre o direito-direto à filosofia como um apelo à democracia por vir, que Derrida definiu em outro momento "como sentido à espera, ainda vazio ou em vacância da palavra ou do conceito de democracia” (DERRIDA, 2009c, p. 52).
} 
segundo Derrida, tem dividido de forma múltipla o espaço filosófico, em muitas margens.

Em Right to Philosophy (2002), Derrida aponta uma divisão advinda pela pergunta “O que é a filosofia?”, que pode ser pensada a partir de duas figuras dominantes, na tradição, opostas uma à outra, como essência e função. Do lado da essência, quer se pensar a "filosofia como tal, o que ela é, o que ela tem sido, o que ela antecipa sendo desde sua origem - e se fará disso precisamente por dar lugar ao momento do evento que estabelece a si, na experiência de uma linguagem, sobre a base da questão do ser ou da verdade do ser" "69, que marca também a figura da destruktion de Heidegger. Do outro lado, a função passa a denunciar o problema do originalismo - reivindicado pela primeira posição que "nos ensinaria nada sobre uma verdade pragmática da filosofia"70; trata-se de uma abordagem sobre o fazer da filosofia, ou do que é feito sob seu nome,

(...) sobre a parte [parti] que fazemos dela, a parte [parti] ou as partes [parti] que tomamos nela, em atos de fala, discussões, avaliações, práticas sociais, políticas e institucionais, cuja diferença, sobretudo, deve ser compreendida, em vez do fio genealógico que os reconectaria a alguma emergência esquecida $^{71}$.

Para Derrida, ambas as figuras giram em torno do sujeito da filosofia, portanto, uma pressupõe a outra, para iniciar ou terminar. Essa pergunta do sujeito da filosofia pode definir alguma identidade para a coisa filosófica, mas ao mesmo tempo enclausura a filosofia num espaço disciplinar onde a filosofia exerce o direito de autodeterminação da sua relação consigo mesma. Porém para que qualquer autoimunidade da instituição filosofia seja efetiva ela precisa criar suas margens à beira da exposição à alteridade. A instituição filosófica, na cavidade de seu arquivo, precisa ao mesmo tempo acolher e denegar o outro, bem como como partilhar seu arquivo entre herdeiros. Hospitalidade e partilha são princípios da estrutura sacrificial daquilo que chamamos filosofia.

Sobre esse aspecto, Derrida nos diz: "Filosofia, identidade filosófica, é também o nome de uma experiência que, na identificação em geral, começa por se ex-por: em outras palavras, se expatriar. Tomar lugar onde ela não toma lugar,

\footnotetext{
${ }^{69}$ DERRIDA, 2002b, p. 7.

${ }^{70}$ Idem.

${ }^{71}$ Ibid, p. 8.
} 
onde o lugar não é nem natural, nem originário, nem dado" "72. É nas margens da exposição ao outro da estrutura sacrificial que se dá a desconstrução da instituição filosófica. A partir desse pensamento a questão da conjugação do pensar a filosofia com o pensar a dança ganha uma brecha pelo apelo à abertura do espaço filosófico e a sua democracia.

Pensar a democracia no espaço filosófico seria então uma brecha para a dissolução do modo disciplinar na filosofia? $\mathrm{O}$ apelo do pensar com a dança na filosofia acabaria com a singularidade dos títulos ou dos direitos que esses nomes carregam? Sim e não. A duplicidade dessa resposta depende de como começamos a entender a necessidade ou a fatalidade dessas pressuposições comuns, e portanto não se deve ler como sim para a primeira pergunta e não para a segunda. A oscilação se mantém para as duas. A temeridade anunciada por tais pressuposições se coloca somente assumindo os limites da instituição filosófica como a própria filosofia. Porém, a mesma temeridade marca o problema da discussão de um outro espaço para a experiência ou a prática de pensamento na filosofia, aquele que Derrida também chamou de democracia por vir como "sim ao pensar". Se acompanharmos bem o dom e a dação da abertura do pensamento na filosofia, que não representa, de maneira alguma, nenhuma simples autoridade nem autorização de se poder falar em seu nome, veremos que proponho um gesto de direito à filosofia, mesmo quando pensando com a dança, como um gesto de democracia por vir, desde a experiência da língua e sua ipseidade de poder anunciar, como um lançamento e uma promessa, um "eu posso".

Antes de desenvolver essa questão, num rápido desvio, preciso, por precaução, apontar que o projeto de Marie Bardet (2014) já avança muito a respeito da questão do pensamento da filosofia com dança, por um caminho bastante outro, lembrando que tal discussão nos conduz à questão da aproximação de campos e da demarcação dos limites da tradição que distanciam filosofia e dança pelo antagonismo de teoria e prática. Bardet nos lembra que a questão de Sócrates, no Banquete, de Xenofonte, que se vê - longe dos olhos dos outros -

\footnotetext{
${ }^{72}$ Idem.
} 
“dançando no espelho, estudando seus movimentos e suas atitudes em uma confrontação confusa com o seu reflexo" "73 marca já na tradição essa espacialidade de mudança de lugares e de discursos entre bailarino e filósofo como "um encontro das medidas e desmedidas dos jogos do sensível e da representação" "74. Tal aparição de Sócrates se percebendo como dançarino aparece no seu relato como um sentimento de confusão com sua imagem e sua atitude. Logo ele, que sempre soube como intervir nos debates, relata sua experiência sabendo que seria objeto de troças. Dessa imagem clássica nos diz Bardet:

Será que essa dança ainda é filosofia? Trata-se de uma questão que os risos e as zombarias dos convivas do banquete apresentam quando Sócrates conta que dança diante de seu espelho, sabendo bem que será objeto de troças. Será que ela é uma consciência de si da filosofia, vendo-se dançar, como um saber sintético de todos os seus pontos e de sua medida? Ou será que ela passou para outra dimensão, na intensidade dos reflexos do movimento no espelho? Em uma imagem que se esboça simetricamente e, no entanto, em outro lugar, sem que nem a dança nem a filosofia tenham totalmente lugar nesse reflexo? ${ }^{75}$

Sabendo que nunca saberemos exatamente que dança dançava Sócrates diante do espelho, para Bardet, a dimensão desse outro espaço de diálogo entre filosofia e dança viria, hoje, no exercício de revezamento teórico-prático, emulando uma perspectiva do diálogo de Gilles Deleuze e Michel Foucault em $O s$ Intelectuais e o Poder (1972), em suas palavras, de "perfurar a parede"76 entre filosofia e dança. Sua proposição partiria de uma retomada da experiência de Sócrates diante do espelho, onde a dança não aparece meramente como objeto do olhar do filósofo sobre a dança, mas se confunde mesmo com a sua atitude, com

\footnotetext{
73 BARDET, 2014, p. 10.

${ }^{74}$ Ibid., p. 11.

${ }^{75}$ Ibid., p. 12.

${ }^{76}$ Gilles Deleuze, pensando o que atribui como "viver de maneira nova as relações teoria-prática", propõe um pensamento de revezamentos desde uma questão de espacialidade. Diz: "Por um lado, uma teoria é sempre local, relativa a um pequeno domínio e pode se aplicar a um outro domínio, mais ou menos afastado. A relação de aplicação nunca é de semelhança. Por outro lado, desde que uma teoria penetre em seu próprio domínio encontra obstáculos que tornam necessário que seja revezada por outro tipo de discurso (é este outro tipo que permite eventualmente passar a um domínio diferente). A prática é um conjunto de revezamentos de uma teoria a outra e a teoria um revezamento de uma prática a outra. Nenhuma teoria pode se desenvolver sem encontrar uma espécie de muro e é preciso a prática para atravessar o muro" (FOUCAULT, 2015, p. 129-130). É desse gesto de perfuração que Bardet anuncia seu encontro entre filosofia e dança, entre pensar e mover.
} 
as suas mudanças de postura, entre pensar e mover: "olhar corpos que dançam, nossos e outros, no presente, de maneira diferente daquela do tempo de Sócrates, e ver como neles se enlaçam, segundo outro registro de revezamento entre "pontos teóricos', quando considerados conjuntamente, os gestos que se fazem igualmente ao filosofar" ${ }^{\prime \prime 7}$. A questão do corpo aparece central na sua elaboração, visto que seria essa uma experiência comum entre filosofia e dança: "o corpo nos faz pe(n)sar sobre a Terra", é a própria experiência de ancoragem no mundo. A escrita conjunta de Bardet, entre pesar e pensar na experiência de mundo, advém do gesto de Nancy elaborado em Le Poids d'une Pensée (1991), e é sem dúvida uma grande contribuição para o pensamento da filosofia com dança, a qual não aprofundarei aqui por desviar muito dos próximos passos desta escrita ${ }^{78}$. Porém quero ainda arriscar outros lances que escapam ao projeto de Bardet.

Bardet nos a ajuda a pensar o problema da mobilidade da filosofia com dança para além da questão de mera negação - até porque, como nos mostra a autora, há em algumas filosofias uma certa atração pela dança, de alguns poucos filósofos que escreveram sobre ela, sobretudo sobre a imagem de uma bailarina dançando, já marcando a questão da leveza (as múltiplas metáforas de elevação de espírito, entre peso, levitação e efemeridade) como um problema de sexualidade e gênero: o filósofo diante da bailarina que estimula o espírito filosófico. Não esqueçamos, também, que a irrequieta mobilidade da dança, da sua impossibilidade de ser plenamente um objeto $^{79}$, por séculos tem eximido a construção de teorias sobre a dança, para além do discurso da lamentação marcada desde os primeiros manuais de coreografia ${ }^{80}$. Pensar uma filosofia com dança precisa, portanto, sair do puro e simples discurso de descrédito da dança diante da filosofia. Minha contribuição nesse debate, o pensar a questão da democracia por vir na filosofia com a dança, está além dessa trincheira. Até porque, como escrevi acima a respeito do espectro-Carmen, talvez eu esteja interessado também na discussão sobre filosofia com dança que nem sempre se fenomenaliza, não se dá claramente ao visível, nem mesmo por reflexo, na imagem de um filósofobailarino diante do espelho.

\footnotetext{
${ }^{77}$ BARDET, 2014, p. 14.

${ }^{78}$ Para acompanhar a associação entre peso e pensamento de Bardet com Nancy: v. Bardet, 2014, notadamente, pp. 22-70.

${ }^{79}$ No quinta seção discutiremos a questão do objeto e a dança.

${ }^{80}$ LEPECKI, 2006.
} 
A diferença que gostaria de ressaltar entre a proposição de Bardet e a desconstrução que venho pensando aqui está marcada na questão da impossibilidade da posição de se estar diante de uma dança, de uma dança que se anuncia num certo horizonte de possibilidades. O anúncio aqui é outro... Estou trabalhando nele passo a passo, desde o título da tese. É uma questão de espaçotempo, de um certo "quando", da "chegada" de um pensamento que vem dançando, do tremor provocado nessa chegada. Sobre essa chegada que nunca se dá no horizonte, repito.

A escrita que venho insistindo com Derrida é também mais do que um momento de uma virada da mesa, em que aquele que se via antes teorizado como objeto se vê agora sujeito de sua própria teoria ou ainda de um revezamento entre esses dois exercícios. A demora com Derrida e os desvios indiretos com seus rastros tensionam a questão do porvir e o problema do horizonte na prática do pensamento. No debate com Derrida, o revezamento teoria-prática é exercido exatamente quando se exorbita o problema do justificar-se enquanto uma teoria, enquanto promessa de uma efetividade de uma teoria, que positiva o brilho para além da clausura. Nesse sentido, poderíamos dizer que tal exorbitância se aproxima ao revezamento de teoria e prática, revezamento do exercício de poder, tal como Foucault em diálogo com Deleuze (1972) nos diz ser necessário trazer às luzes e discutir publicamente, sendo um primeiro passo para se manter em luta ${ }^{81}$.

Não se trata, assim, de se produzir uma teoria que resulta de uma prática, mas, sim, de levar a sério o exercício da teorização como uma prática, portanto, uma política que excede as categorias gerais da análise tradicional dos aparelhos de Estado que não esgotam o campo de exercício e funcionamento de poder. Porém, de nenhuma maneira, esse pensamento encerra a questão da representação, e, assim, a proposta que se exercita aqui não vai ao encontro do pensamento de

\footnotetext{
${ }^{81}$ No diálogo com Deleuze, Foucault nos diz: "O papel do intelectual não é mais o de se colocar 'um pouco na frente ou um pouco de lado' para dizer a muda verdade de todos; é antes o de lutar contra as formas de poder exatamente onde ele é, ao mesmo tempo, o objeto e o instrumento: na ordem do saber, da 'verdade', da 'consciência', do discurso. E por isso que a teoria não expressará, não traduzirá, não aplicará uma prática; ela é uma prática. Mas local e regional, como você diz: não totalizadora. Luta contra o poder, luta para fazê-lo aparecer e feri-lo onde ele é mais invisível e mais insidioso. Luta não para uma 'tomada de consciência' (há muito tempo que a consciência como saber está adquirida pelas massas e que a consciência como sujeito está adquirida, está ocupada pela burguesia), mas para a destruição progressiva e a tomada do poder ao lado de todos aqueles que lutam por ela, e não na retaguarda, para esclarecê-los. Uma 'teoria' é o sistema regional desta luta" (FOUCAULT, 2015, p. 131-132).
} 
Deleuze e Foucault ${ }^{82}$, que Bardet parece aspirar quando diz querer produzir um diálogo entre filósofos, coreógrafos e bailarinos sem cair no lugar do teórico que "falaria no lugar daqueles que fazem" $"$. Que o jogo entre apropriação e acúmulo de capital simbólico da fala do outro é um problema, estamos de acordo, mas de maneira alguma a resistência a esse processo encerraria a economia substitutiva, disseminativa e radical da representação.

O debate da democracia por vir na filosofia, tal como pensado por Derrida [que nos lembra da condição da filosofia como uma instituição acadêmica e que define seus limites tal como um estado-político], nos diz que é preciso abrir margens para outras formas de se fazer filosofia, sem para isso designar nenhuma autoridade sobre ela, sem falar em seu nome nem em nome do Outro diante da filosofia. A questão do poder do eu posso se imprime no debate do poder, evidentemente. Porém já se admite que a tomada de posições e a circularidade dos processos de substituição, suplementaridade e distribuição das forças de poder se dão, só podem se dar, no limite da representação.

Representação aqui não é entendida como processo de restituição de uma unidade anterior. Ela possibilita a divisibilidade do logos e da soberania desde o poder falar participando de uma economia da língua, marcada pela vinda do outro e ao outro enviada. É somente já participando dessa economia, no revezamento/substituição de lugares que se ocupa numa dada economia, ainda que

\footnotetext{
${ }^{82} \mathrm{O}$ encerramento da representação no diálogo de Deleuze e Foucault é feito através de muitos gestos conceituais, mas sobretudo parte do entendimento de representação como um poder falar pelo outro, deixando escapar algum sarcasmo quanto às teorias políticas e às formas de organização política baseadas em sistemas de representação: "A teoria não totaliza; a teoria se multiplica e multiplica. É o poder que por natureza opera totalizações, e você diz exatamente que a teoria por natureza é contra o poder. Desde que uma teoria penetra em determinado ponto, ela se choca com a impossibilidade de ter a menor consequência prática sem que se produza uma explosão, se necessário em um ponto totalmente diferente. Por este motivo a noção de reforma é tão estúpida e hipócrita. Ou a reforma é elaborada por pessoas que se pretendem representativas e que têm como ocupação falar pelos outros, em nome dos outros, e é uma reorganização do poder, uma distribuição de poder que se acompanha de uma repressão crescente. Ou é uma reforma reivindicada, exigida por aqueles a que ela diz respeito, e aí deixa de ser uma reforma, é uma ação revolucionária que por seu caráter parcial está decidida a colocar em questão a totalidade do poder e de sua hierarquia (...) A meu ver, você [Foucault] foi o primeiro a nos ensinar - tanto em seus livros quanto no domínio da prática - algo de fundamental: a indignidade de falar pelos outros. Quero dizer que se ridicularizava a representação, dizia-se que ela tinha acabado, mas não se tirava a consequência desta conversão 'teórica', isto é, que a teoria exigia que as pessoas a quem ela concerne falassem por elas próprias" (DELEUZE in FOUCAULT, 2015, p. 132-133). O poder falar por si, em Deleuze, é pensado como o fim do agenciamento pelo outro, reinstaurando, por sua vez, uma certa indivisibilidade da soberania do sujeito que fala. Nesse gesto, não se reconhece o problema da língua, da incondicional ipseidade de se falar qualquer eu já participando de um sistema de trocas, substituições, revezamentos, circularidades. Continuemos.

${ }^{83}$ BARDET, 2014, p. 18.
} 
provisoriamente, que dois homens de direito à filosofia, no exercício do privilégio de seus domínios domiciliares de discurso, podem se reunir e debater sobre a continuidade ou não dos sistemas de representação e, assim, publicar livros e engendrar outros debates, por exemplo.

O poder falar eu, a autodeterminação do sujeito no discurso, é marcado pela economia idiomática de se sentir em casa ao mesmo tempo que não se pode tê-la como própria. O poder do sujeito, desde a língua, que circula nos sistemas de representação, é, então, divisível tanto no espaço que se ocupa quanto no tempo - lançado ao outro radicalmente, apagando já o seu referente - e, portanto, sempre desconstruível não somente para o soberano (que tem poder de fala), como também para o subalterno (que não pode falar) e até mesmo para o intelectual (que por vezes tenta escapar do lugar dos outros dois sujeitos, como se fosse dotado de uma certa transparência no abrigo de seu discurso).

Gayatri C. Spivak, em Pode o Subalterno Falar? (1985), oferece-nos uma observação considerável a esse respeito:

Na conversa entre Foucault e Deleuze, parece que, a questão é que não há nenhuma representação, nenhum significante (devese, assim, presumir que o significante já foi liquidado? Não há, então, nenhuma estrutura de signo acionando a experiência e, por isso, dever-se [sic] deixar a semiótica de lado?); a teoria é um revezamento da prática (deixando, assim, os problemas da prática teórica de lado), e os oprimidos podem saber falar por si mesmos. Isso reintroduz o sujeito constitutivo em pelo menos dois níveis: o Sujeito de desejo e poder como um pressuposto metodológico irredutível; e o sujeito oprimido, próximo de, senão idêntico, a si mesmo. Além disso, os intelectuais, os quais não são nenhum desses $\mathrm{S} /$ sujeitos, tornam-se transparentes nessa "corrida de revezamento", pois eles fazem uma declaração sobre o sujeito não representado e analisam (sem analisar) o funcionamento do (Sujeito inominado irredutivelmente pelo) poder e do desejo. A "transparência" produzida marca o lugar de "interesse", e é mantida pela negação veemente: "Agora esse papel de árbitro, juiz e testemunha universal é algo que eu absolutamente me recuso a adotar". Uma responsabilidade do crítico poderia ser ler e escrever de maneira que a impossibilidade de tais recusas individualistas e interessadas dos privilégios institucionais do poder concedidos ao sujeito seja levada a sério. A recusa do sistema de signo impede o desenvolvimento de uma teoria da ideologia ${ }^{84}$.

\footnotetext{
${ }^{84}$ SPIVAK, 2010, p. 56-57.
} 
Spivak avança no seu texto nos mostrando como a "transparência do intelectual" requerida por Foucault e Deleuze, quando recusam a questão da representação - gesto também pensado por Said como uma forma de "obliterar o papel das classes, o papel da economia, o papel da insurgência e da rebelião" ${ }^{85}$ no discurso intelectual —, produz um S/sujeito imune ao lugar de fala, imune à ipseidade do poder dizer tais pressuposições, livremente, mesmo sendo já assujeitado a um certo regime institucional de memória arquival, de edição, de impressão e de distribuição de textos.

Acredito que Spivak lança uma outra responsabilidade institucional do crítico acadêmico que tensiona o regime de "livre" circulação dos herdeiros da tradição falogocêntrica [outra vez, estamos aqui falando do oikos e do nomos, onde o comando se arquiva no privilégio institucional]. Para a autora, em vez de recusar os sistemas de representação, o crítico, atento à não cumplicidade da constituição do Outro como sombra do Self, precisa pensar radicalmente a economia [da textualidade, da representação, do signo e da herança] sob rasura: "para perceber como o fator econômico é tão irredutível quanto reinscrito no texto social - mesmo este sendo apagado, embora de maneira imperfeita - quando reivindica ser determinante final ou significado transcendental" ${ }^{\prime 86}$.

Esta última passagem de Spivak abre a questão do problema econômico para além do campo intelectual, portanto não exclusivo ao campo da filosofia. A capitalização da vida social é reencenada em todos os campos, em todos os regimes; ela atravessa todo poder de autodeterminação (toda ipseidade) e toda fundação que marca - como um território - certo domínio, um certo bem saber e sua arquiviolítica: o depósito, a guarda, a partilha, a distribuição e o recalque. Essa é uma herança do privilégio dos arcontes: "aqueles que podem evocar a lei e convocar a lei" ${ }^{\prime 87}$. Princípio também reencenado na Orchesographie, de Arbeau, que num tratado homossocialmente construído por homens de lei capitaliza a dança para fins de um certo modo de associação normativa e normalizadora ${ }^{88}$

\footnotetext{
${ }^{85}$ SAID apud SPIVAK, 2010, p. 57.

${ }^{86}$ SPIVAK, 2010, p. 60.

${ }^{87}$ DERRIDA, 2001 a, p. 13.

${ }^{88}$ Permitam-me citar novamente alguns trechos do diálogo de Arbeau e Capriol (que são o mesmo lugar de fala; suplementos um do outro. E não esqueçamos: foram escritos, telecoreografados e impressos, ambos, pelo próprio Arbeau): "Tão naturalmente o macho e a fêmea procuram um ao outro, e nada estimula mais um homem aos atos de cortesia, honra e generosidade que o amor"; "o dançar é praticado para revelar se os amantes estão em boa saúde e de boa forma"; "Não me atormente mais atrasando em conceder o meu pedido de aprender como os movimentos da dança
} 
[assombrados pelo medo da alteridade], para a atração entre corações e para a força e defesa do Estado [ou de outro regime de direito], humores capitalizados em um mesmo fim, em um mesmo telos ${ }^{89}$.

O apelo do pensar com a dança, que tenho feito até aqui, é assumidamente local e portanto não pretende criar uma vigília sobre as práticas da filosofia. A insistência dessa localidade, num primeiro momento, precisa, sim, marcar a questão de um certo domínio de poder na instituição filosófica, para fazê-lo tremer, sem se encerrar na sua mera exposição e deflagração. Quando conjugo a questão do direito à filosofia com a ocorrência de uma dança, ainda que de uma espectral Carmen Miranda telecoreografada, é para, duplamente, afirmar a chamada da filosofia e da dança sem um horizonte: um direito à declaração da filosofia, ainda que com a dança, como um pensar sem horizonte [que valeria também no seu inverso: um direito à declaração da dança, ainda que com a filosofia, como um pensar sem horizonte].

Sobre esse pensar sem horizonte, Derrida nos diz:

\begin{abstract}
Nada deveria ser pressuposto por esse pacto ou acordo: nenhum objeto ou campo, nenhum tema, nenhuma certeza, nenhuma disciplina, nem mesmo o chamado filósofo que se autotitularia sobre as bases de qualquer formação, identidade de pesquisa ou horizonte de questionamentos. A filosofia não tem nenhum horizonte se o horizonte é, como o próprio nome sugere, um limite, se o "horizonte" significa uma linha que circunda ou delimita uma perspectiva ${ }^{90}$.
\end{abstract}

Para Derrida, esse seria um privilégio por vir, antes da constituição de objetos próprios, antes da constituição da noção de campo ou epistemologia. Portanto, não é uma discussão sobre interdisciplinaridade na filosofia, pois excede a questão da disciplina. Trata-se de um pensamento radical da filosofia como sim

\footnotetext{
são realizados, a fim de que eu possa dominá-los [in order that I may master] e não ser repreendido por ter o coração de um porco e a cabeça de um jumento"; "É um preliminar e, como eu já lhe disse, um dispositivo útil para descobrir se uma pessoa é deformada por gota ou ainda defeituosa dos membros".

${ }^{89}$ Desenvolverei mais a questão do fator econômico, sua relação com o princípio arcôntico e as implicações para os campos da dança e da performance na quinta seção desta tese.

${ }^{90}$ DERRIDA, 2002b, p. 16. [Grifos do autor]
} 
a pensar. Estamos falando de uma filosofia que não se encerra na sua prática como disciplina, tampouco se contenta com o diálogo de si com outras disciplinas, pois haveria uma inconstitucionalidade marcada pela abertura do sim. Não se trata, portanto, de um apelo de legitimação da dança ou de objetos "externos" à filosofia como um objeto de pesquisa. Tal pressuposição seria não somente ingênua, como também contraditória à questão do direito à filosofia como um sim ao pensar, pois este se colocar anterior a qualquer pressuposição institucional que poderia vir a autofundar-se para legitimar ou não objetos até então não filosóficos que, na atribuição de um direito dado, passassem a ser filosóficos - até porque essa é a regular operação de qualquer instituição tradicional de filosofia.

Para Derrida, este sim difere do direito já pertencente à tradição da filosofia, que pressupõe a memória e a tarefa de um projeto de resposta à pergunta “o que é a filosofia?”, como já me referi anteriormente, "quer sob a lógica do acontecimento original ou numa lógica de função pragmática". Por um lado, responder a cada tempo, de tempos em tempos, à pergunta "o que é a filosofia?" supõe como tarefa a revisão e/ou lançamento de novos objetos ou questões para a filosofia, em sua continuidade institucional. Por outro lado, o sim ao pensar arromba o pressuposto de pertencimento ou identificação de uma comunidade filosófica ou, nas palavras de Derrida, "comunidade da pergunta" que institui ou pressupõe uma interlocução ou "intersubjetividade" que se reconhece e faz circular uma memória, uma genealogia ou projeto de sujeito da filosofia. O sim ao pensar reivindicado por Derrida quer "admitir o pensar, a prática e a experiência de um 'direito à filosofia' sem recorrer ao determinado pressuposto ou essência de filosofia"91 , seja de uma ontologia ou de uma genealogia do sujeito. O sim é a resposta que se dá, incondicionalmente, à vinda do outro que vem.

Por sua vez, este sim, diz Derrida, "não nos daria ou demandaria o direito a pressupor nem uma resposta nem uma formulação para a pergunta 'O que é filosofia?’ (...) ou até mesmo a possibilidade de uma questão geral"92. Da mesma maneira, “pensar este 'sim' antes da filosofia, antes da questão mesma, antes da pesquisa e crítica não significa uma renúncia da filosofia, do que poderia segui-la ou seguir a partir dela" ${ }^{93}$. A oscilação do nem/nem derridiano marca uma

\footnotetext{
${ }^{91}$ Ibid., pp. 12-13.

${ }^{92}$ Ibid., p. 13. [Grifos meus].

${ }^{93}$ Idem. [Grifos e comentários meus].
} 
resistência à formação de genealogia ou sujeito da filosofia que se reúna em torno de seus objetos, de uma comunidade de pensamento ou ainda de uma epistemologia que dirija o exercício ou a prática do sim ao pensar. Trata-se de uma resistência ao movimento direto, à alegórica caminhada para a razão, às luzes de uma determinada razão pressuposta no limite ou no alcance dos olhos, num horizonte de possibilidades. Derrida insere, assim, na desconstrução um apelo à inventividade que foge à formulação das questões filosóficas.

O problema da formulação e identificação "da questão filosófica", para Derrida, é que ela nega os processos de alteridade que a formulam. Em nome desse movimento direto à questão filosófica, não se pergunta sobre o seu direito, sobre o chão e os suportes que marcam a distância necessária para a formulação de um horizonte de sentido, o longo e complicado processo de autorização de pressuposição institucional.

\begin{abstract}
A questão (e com ela todas as formas de negação, pesquisa, crítica) envelopa nela uma afirmação, pelo menos o "sim", à afirmação de nenhum outro conteúdo se não a alteridade, precisamente, a quem um rastro é dirigido, mesmo se à escuridão. O pensamento deste "sim" antes da filosofia, mesmo antes da questão, antes da pesquisa e da crítica, significa que não há renúncia à filosofia, que pode acompanhá-la ou segui-la. Ele pode, este pensamento, pode-se até pensar que ele deve justamente engajar. Esse pensar pode, pois, como o dever ou a dívida, já está engajado [engagée], inscrito no espaço aberto e fechado por esse juramento [gage] - dado ao outro, do outro recebido. Mas ele desenha uma forma de contorno estranho entre todas as determinações filosóficas e um pensamento desconstrutivo que está engajado pela filosofia, sem lhe pertencer, fiel a uma afirmação cuja responsabilidade coloca-se diante [devant] da filosofia, mas sempre antes [avant] da filosofia, aquém ou além da filosofia, figuras identificáveis de identidade filosófica, questão filosófica sobre o sujeito da filosofia e até mesmo da forma-questão do pensamento. É nesta terceira possibilidade que está comprometida a desconstrução, como parece necessário ou melhor, como parece exigir o pensamento ${ }^{94}$.
\end{abstract}

Nesse gesto, a desconstrução nos força a pensar diferentemente as instituições da filosofia e o direito à filosofia. Mas Derrida faz uma objeção a esse outro privilégio do sim, lembrando que ele não determina nenhuma exclusividade

\footnotetext{
${ }^{94}$ DERRIDA, 2002, p. 13.
} 
em oposição à ciência, à técnica, ao cálculo e à estratégia [esta última muitas vezes associada ao trabalho da desconstrução pelo próprio Derrida, “desconstrução como estratégia"]. A marca entre esse "pensar" e "a filosofia, o pensamento, a ciência etc.", em Derrida, "nunca tomou a forma e a função que Heidegger dá" 95 , e a distância à proposição heideggeriana é referida por Derrida em muitos trabalhos ${ }^{96}$. Mais adiante, Derrida sugere que tal demarcação da palavra pensar [pensée] "é apenas justificada estrategicamente e provisoriamente" ${ }^{97}$ para designar o que excede ao modo particular de pensamento que seriam a filosofia e a ciência, por exemplo.

Pensar o sim - pensée, thinking, denken: essa tradução nebulosa excede a filosofia-mesma, não é propriedade filosófica. Derrida nos lembra que a passagem de pensée a denken, um certo gesto heideggeriano que associa denken/danken [pensamento/gratidão], está associada a um determinado sistema léxico e "devemos considerar as consequências desse fato" ${ }^{98}$. Pensar - outra tradução - , o trabalho sobre o sim da abertura de um pensamento singular, se dá sempre no acolhimento de uma língua, na hospitalidade radical de uma experiência idiomática singular, portanto nunca poderia ser objeto nem mesmo horizonte que reúne uma comunidade filosófica. O espaço-tempo que se dá na tradução de um pensar não pode ser simplesmente ignorado. É incondicional. Só há pensar dentro de um certo monolinguismo, de uma certa ipseidade, sem a qual não há qualquer soberania de um direito, o poder dizer antes do eu posso, antes que qualquer sujeito. Já se pensa estando no espaço-tempo de uma língua que se tem como própria, sem nunca a ela pertencer.

Teremos que fazer um deslocamento estratégico, mais uma vez, sobre a questão que se coloca entre língua e soberania, no poder dizer eu posso, a partir da desconstrução de Derrida. Tal gesto será necessário para que possamos continuar pensando a impossibilidade do direito-direto à filosofia como apelo à democracia

\footnotetext{
${ }^{95}$ Idem.

${ }^{96}$ Derrida, em nota, diz: "Eu tenho insistido nisso, mas frente ao interesse de algumas pessoas obstinadas em ignorá-lo, para me fazer julgamento, eu ainda remeto, pelo menos para lembrete, ao trabalho que faço em: Psyché, Inventions de l'autre (Galilée, 1987, p. 395-451), De l'esprit (O.C. especialmente, p. 23 sq.) ou Mémoires. Pour Paul de Man (Galilée, 1988, passim)" (DERRIDA, 2002 , p. 195, nota 10).

${ }^{97}$ Ibid., p. 20.

${ }^{98}$ Idem.
} 
por vir, que é também a razão por vir na filosofia como uma declaração do sim sem horizonte ${ }^{99}$.

De partida, sim! Dois desvios necessários, ainda com Derrida:

I.

Em O Monolinguismo do Outro (2001), Derrida nos diz que a experiência da língua reserva sempre o paradoxo de sentir-se em casa e nunca ser-lhe própria, pois é aprendida do outro e ao outro enviada. ${ }^{100} \mathrm{~A}$ lei da língua que é também a língua como lei: "não falamos senão uma língua - e [...] não a temos. Não falamos nunca senão uma língua - e ela é dissimetricamente, a ele regressando, sempre do outro, do outro, guardada pelo outro. Vinda do outro, permanecendo do outro, ao outro reconduzida"101. A monolíngua apontada por Derrida não tem a ver com a impossibilidade do poliglotismo, mas coloca a alteridade como lei

\footnotetext{
${ }^{99}$ Derrida sempre posicionou a desconstrução como uma tarefa de se pensar o impossível. Diz o autor: “(...) As mais rigorosas desconstruções nunca se autoproclamam como possíveis. E eu diria que a desconstrução não perde nada em admitir que ela é possível (...). Possibilidade, para uma operação desconstrutiva, significaria, antes, o perigo. O perigo de se tornar um conjunto disponível de procedimentos, métodos e aproximações acessíveis baseados em regras. O interesse da desconstrução, de uma tal força e desejo que ela possa ter, é uma certa experiência do impossível (DERRIDA, 1994 apud DUQUE-ESTRADA, 2008, p. 14). A impossibilidade da desconstrução é, portanto, um convite à inventividade do sim ao pensar. É na tentativa desse gesto impossível e inventivo que sigo pensando com a dança na filosofia e pensando com a filosofia na dança.

${ }^{100}$ Importa lembrar que o outro no pensamento derridiano não diz respeito ao próximo, ao “outrem", mas, sim, a todo processo que sempre escapa, nunca chega plenamente e demarca a impossibilidade de retorno a si mesmo, a um autos. Alteridade radical; estrangeiro radical, como índios [se pudermos recuperar a força anárquica e não capturável evocada por esse termo: uma outra soberania de nunca ser domesticado nem domiciliado], exterioridade absoluta que não se deixa jamais reduzir-se ao par dicotômico dentro/fora. A alteridade derridiana está sempre por vir, alhures, nunca totalmente endereçável ao mesmo tempo que é toda possibilidade de endereçamento/envio; uma brecha ou força de escape que pode chamar, atrair, mas também trair ao chamamento. Nesse sentido, nunca é uma reunião integradora - e aqui tensiono uma distância sobre a noção heideggeriana de coisa, thing (cf. HEIDEGGER, 2008). A noção de alteridade como porvir em Derrida, talvez, fale de uma coisa ainda mais radical, que na sua coisidade pode vir a perturbar a possibilidade de todo e qualquer reunir a si plenamente. Evidentemente, há nessa alteridade radical uma atração - por vezes marcada como uma retração (que para Heidegger é o que nos acomete, como acontecimento, a-se-pensar) - pelo pensamento heideggeriano ao qual Derrida nunca se furtou. É também esse gesto de aproximar-se e manter-se a distância que o pensamento derridiano está marcado como différance - que nunca foi oposição, mas, sim, uma brisura, articulação como diferença, tomado por Heidegger e para além de Heidegger, como em outros momentos tomado por Nietzsche para além de Nietzsche, Freud para além de Freud, Artaud para além de Artaud, Lévinas para além de Lévinas, para citar alguns [Sobre brisura: cf. DERRIDA, J. Gramatologia. São Paulo: Perspectiva, 1977].

${ }^{101}$ DERRIDA, 2001b, p. 57.
} 
incondicional a qualquer poder dizer ${ }^{102}$. Essa vinda do outro, o vir que vem, é anterior ao sujeito, ser ou casa.

O poder dizer, como eu posso, é marcado, portanto, pela dupla incondicionalidade que atravessa a ipseidade, desde a língua:

E, antes da identidade do sujeito, o que é a ipseidade? Esta não se reduz a uma capacidade abstrata para dizer "eu", que terá sempre precedido. Significa talvez, em primeiro lugar, o poder do "eu posso", mais originário do que o "eu", numa cadeia em que o "pse" de ipse não se deixa mais dissociar do poder, do domínio ou da soberania do hospes (refiro-me aqui à cadeia semântica que trabalha no corpo a hospitalidade tanto quanto hostilidade - hostis, hospes, hosti-pet, posis, despotes, potere, potis sum, possum, pote est, potest, pot sedere, possidere, compos, etc. ${ }^{103}$.

O hospedeiro já não se deixa dissociar do hostil. É a primeira incondicionalidade dessa ipseidade: a abertura ao outro como acolhimento hostil. A soberania do $e u$, do poder dizer $e u$ frente ao outro, guarda a captura do outro para si. Ao mesmo tempo, é também esse esquema de retorno a si de uma soberania que cria leis de acesso, paragens, interdições, tomadas de participação e distribuição frente ao outro. É somente nessa ipseidade de acolher e ser hostil que se pode constituir qualquer "sistema convencional, simultaneamente lógico e social, que prescreve e outorga a predominância de um certo tipo de raciocínio, aquele que submete ao direito o consenso procurado e as conclusões de um debate ou de um conflito"104 - o que definimos como um Estado de direito - , não esquecendo que qualquer contrato é sempre feito dentro de uma língua, cujas partes possam responder umas às outras. A ipseidade da língua é, pois, como uma lei incondicional para que se institua qualquer direito.

Se a língua que se fala é a do lugar de direito que se pode falar, alguém poderia perguntar: e quem de direito poderia colocar essa questão, senão mesmo

\footnotetext{
${ }^{102}$ Das poucas vezes que Derrida arriscou definições para o movimento que foi sendo chamado de desconstrução, ressaltou: "Se tivesse de arriscar, Deus me valha, uma única definição da desconstrução, breve, elíptica, econômica, como uma palavra de ordem, diria sem frase: plus d'une langue" (DERRIDA, 1988 apud DERRIDA, 2001b, p. 2). Nessa sentença, é preciso destacar o jogo duplo demarcado sobre o "plus de", que tanto pode significar "mais de uma língua" quanto "já não hálbasta de uma língua", apontando, assim, uma incondicional multiplicidade da língua como lei. Com essa quase definição econômica e arriscada, a desconstrução enceta duplamente a tradução como produção de diferença e agência do outro-outro, do estrangeiro irredutível, que ao mesmo tempo é a vitalidade e a ameaça sempre por vir de todo texto (ANDRADE, 2013).

${ }^{103}$ DERRIDA, 2001b, p. 27.

${ }^{104}$ DERRIDA, 2009c, p. 33.
} 
um filósofo? Num lance especulativo, poderíamos responder: falar do right to [direito-direto à] filosofia é já falar, desde o título, do lugar de quem de direito e de uma língua pode atribuir tal questão. Ora, mas tal premissa soa já como um atalho, um movimento direto à coisa filosófica - “A formulação de tal questão é já um exercício filosófico", diria aquele alguém —, já assumindo que há alguma singularidade que toma a forma de filosofia, por uma ideia filosófica, um filosofema. Formular uma questão institucional ou técnico-jurídico-política do direito-direto à filosofia, para além do dispositivo de escrita ou de ensino, para além da legitimidade de uma certa comunidade acadêmica, sem mediação, nem interdição, nem limitação, é já tocar a filosofia mesma, o próprio da filosofia. Estaríamos aqui encerrando muito rapidamente o "falso" problema do privilégio reivindicando o privilégio do próprio filosófico. Pela soberania do pensamento filosófico, da experiência que se autofunda na formulação de suas próprias questões, a questão do privilégio, de partida, e retoricamente, estaria descartada.

Derrida nos ajuda a formular e desviar esse atalho:

\begin{abstract}
Essa filosofia não teria medo de qualquer ataque. Ela não precisa ser justificada ou defendida, não, de qualquer sorte, por qualquer outra coisa senão ela mesma. É próprio da filosofia dizer o que é próprio dela, e assim assegurar sua defesa e justificação própria. Mesmo se o fora luta ou trabalha para ajudá-la nessa tarefa, será como um auxiliar, um suplemento e mesmo um supletivo [suppletive]; e o limite entre propriedade interna e suplementaridade externa deve permanecer como claro e indivisível como o limite entre o interno e o externo. Aqui se reconhece uma "lógica" - e assim uma estratégia - aberta às mais insistentes e formalizadas questões desconstrutivas ${ }^{105}$.
\end{abstract}

Sem esquecer que esta escrita é uma tese de filosofia que seguiu todos os protocolos reservados a esse direito e que será submetida a uma banca de direito, sobretudo do direito à atribuição de um título, caberia aqui uma confissão: estou jogando essas telecoreografias ${ }^{106}$ dentro do privilégio filosófico, como um duplo. De um lado, somente posso me demorar em tal questão circulando numa certa linguagem filosófica; por outro lado, quero marcar a coerção e o limite desse gesto.

\footnotetext{
${ }^{105}$ DERRIDA, 2002, p. 24. [Grifos e comentários meus].

106 Telecoreografia aqui já sendo entendida como qualquer teletransportação e tradução advinda de um gesto de incorporação/excorporação a distância.
} 
Voltemos à última passagem de Derrida. Num primeiro momento, observemos a cena sugerida: essa filosofia que de direito vai direto à coisa filosófica, como em um movimento reto de direito - se tal coisa existisse (e a especulação está marcada pela forma do futuro do pretérito em teria), "não teria medo de qualquer ataque", diz Derrida. A formulação verbal nos deixaria ainda arriscar a dizer que, se houve essa filosofia sem medo, certamente, já há muito, não há mais. Ou ainda, se tal coisa existisse, estaria condicionada a uma lei ou a um conjunto de forças e estratégias que asseguram o privilégio de não ter medo, portanto já subjugada, repreendida a não ter medo - um paradoxo de viver sob medo para não ter medo. Um certo direito constituído de ir direto à filosofia, em que o sem medo é também uma não oscilação, uma não obliquidade, própria do privilégio de atribuição da participação na comunidade arcôntica dos herdeiros da filosofia. Nesse gesto, incondicionalmente, a filosofia que pratica o interdito atribui e nega títulos, medeia forças dentro da estrutura institucional, é assombrada pelo medo do fora. Confia-se no poder do título filosófico para não se temer o estar fora da filosofia. A arqui-falo-pedagogia logocêntrica como a primeira lição [telecoreograficamente iterada] que precisa ser aprendida: é preciso ter medo para não ter medo.

Em um segundo momento, nessa mesma passagem, Derrida nos convida a pensar sobre a limitação topológica do fora/dentro da filosofia. Um lugar onde a força do próprio é mediada pela evitação da alteridade. Se há violência e animosidade, essas se dão na saída da filosofia de si, se dão nos "fenômenos públicos da filosofia, publicações, dispositivos educacionais (a academia, a escolástica ou a doutrina), mas não no interesse filosófico"107, naquilo que é próprio do ser-filosófico.

Mais adiante, Derrida irá também dizer que a noção de objetividade tornou-se assim o tom popular de "rigor" e "sinal de boa filosofia". Essa seria, por sua vez, uma herança da crítica kantiana, da necessidade do uso público da razão. A noção de rigor nessa herança, que excede a Kant mesmo - como toda herança, é sobretudo definida por uma relação análoga entre o nome do direito e o advérbio direto, marcada por três razões sistemáticas e históricas:

${ }^{107}$ DERRIDA, 2002, p. 24. 
(1) porque Kant nos diz algo sobre a oposição direto/curvo ou direto/oblíquo na problemática do direito (Recht, Jus); (2) porque da muito óbvia e próxima comunicação entre o discurso de tipo kantiano e o momento da Revolução Francesa ou o momento da Declaração Universal dos Direitos do Homem; (3) porque os discursos que certas ciências sociais trazem à pedagogia institucional, notadamente do ensino de filosofia, em si dão à herança kantiana uma paradoxal predominância. Isso acontece de diversas maneiras, notavelmente, entre os mais marcantes e remarcados trabalhos pela regra dada às problemáticas de objetificação (e da objetificação da objetificação) ou legitimação, até mesmo licitação ${ }^{108}$.

Depois, Derrida diz que a popularidade de Kant é notadamente marcada e marcante na linguagem filosófica, ou melhor, na predominância de seu discurso. Cito:

A linguagem da filosofia (a implementação discursiva de uma linguagem dentro da linguagem) deve de fato tornar-se popular, responde Kant a um certo Garve, somente se este imperativo for o de conduzir o filósofo a negligenciar, deixar de reconhecer ou, pior, conduzir seus leitores a ignorar distinções rigorosas, divisões decisivas, questões essências para o pensar ${ }^{109}$.

Derrida está se referindo à distinção entre as noções de sensível e inteligível, às quais as "mais diversas abordagens desconstrutivas têm combatido por longo tempo" ${ }^{110}$. Tal distinção, estrategicamente, ainda é crucial nos debates de filosofia - sobretudo aqueles dentro de um certo regime da pergunta "o que é...” - e na sua inserção no espaço público e nos meios de comunicação ${ }^{111}$. As

\footnotetext{
${ }^{108}$ Idem, p. 43.

${ }^{109}$ Ibid, p. 44.

${ }^{110}$ Idem.

${ }^{111}$ Derrida pensa a questão da inserção da filosofia no espaço público ao se referir à herança kantiana. Em a Doutrina do Direito, o pensador alemão, concordando com o Christian Garve (1742-1798), marca a premissa do tom popular de ensino da filosofia crítica como popular, no sentido de: "suficientemente claro ao sentidos (...) sob pena do mestre tornar-se suspeito de estar desnorteado em meio às suas próprias concepções" (KANT, 2003, p. 52, grifos meus). Derrida irá pensar essa "cenografia sócio-pedagógica" (DERRIDA, 2002, p. 45), essa espacialidade do filósofo diante do outro, no espaço público, notando como a filosofia crítica de Kant pensa a vinda do outro como ameaçadora a soberania do pensamento filosófico. No espaço público, o filósofo pode ser acusado de obscuro e desnorteado e é a partir dessa ameaça, dessa constrição vinda do outro, que o pensamento kantiano irá pensar as noções de rigor e prudência filosóficas, conectando clareza, direito e retidão. Vejamos a passagem completa de Kant a qual Derrida irá se demorar para pensar como a noção do pensamento do "direito" advinda da herança alemã é atravessada pela noção de movimento "direto", retitude, que, ao mesmo tempo, se define como lei assombrada pelo desvio do outro: "Os tratados filosóficos são com frequência acusados de serem obscuros, na verdade deliberadamente destituídos de clareza com o fito de afetar uma ilusão de profundo entendimento. Não há melhor forma de me prevenir ou remediar quanto a essa acusação do que
} 
heranças de "rigor" e "prudência" kantianas, para Derrida, porém, encontram um certo limite quando pensadas dentro de um redimensionamento das noções de público, mídia e democracia por vir. O apelo de tal crítica espacializa uma cenografia socio-pedagógica na filosofia exatamente neste gesto adverbial, direto a filosofia, no tom da linguagem popularmente filosófica, seu espaço de direito.

Derrida irá lembrar que a analogia entre direito e o advérbio direto aparece num comentário - que não é o texto principal, e é importante destacar essa suplementaridade essencial - do parágrafo E, da Introdução da Doutrina do Direito (1797), em que Kant tenta justificar que tal analogia é oposta à obliquidade ou à curva - que ecoa na mesma oposição entre certo ("no sentido do que é direito ou reto, gerade""112) e errado (o que é curvo, krumm, "no sentido espacial ou físico, que também significa, de acordo com uma figura psicológica ou moral, o que recolhe ou eleva toda a questão, torcida, desviante, enganadora"113). Em último caso, está em jogo uma certa ética ou conduta de

\footnotetext{
prontamente me conformar a um dever que Garve, um filósofo no autêntico sentido da palavra [e que ministrou cursos de filosofia em Leipzig], estabelece para todos os escritores, mas especialmente para os autores de filosofia. Minhas únicas limitações são impostas pela natureza da ciência a ser retificada e ampliada. Essa sábio exige com acerto (em sua obra Vermischte Ausfsätze, págs. 352 e segs.) que todo ensino filosófico possa ser popularizado (isto é, tornado suficientemente claro aos sentidos a ponto de ser comunicável a todos) sob pena do mestre tornarse suspeito de estar desnorteado em meio às suas próprias concepções. É com contentamento que admito isso salvo unicamente pela crítica sistemática da própria faculdade da razão, juntamente com tudo que só pode ser estabelecido por meio dela, pois isto tem a ver com a distinção entre o sensível em nossa cognição e aquilo que é supra-sensível, mas ainda assim concernente à razão. Isso jamais pode ser popularizado - nenhuma metafísica formal o pode - , embora seus resultados possam ser tornados bastante esclarecedores para a razão saudável (de um metafísico inciente). A popularidade (linguagem comum) está fora de cogitação aqui, mesmo que isso seja censurado com sutileza (posto que se trata da linguagem das escolas); pois somente por tal meio a razão precipitada será levada a entender a si mesma antes de realizar suas asserções dogmáticas [ $a$ mesma passagem está traduzida por Derrida como: "Il ne faut pas penser ici à quelque popularité (langage du peuple), mais l'on doit en revanche s'attacher à la ponctualité scolastique, même si elle est blâmée pour son caractère désagréable (c'est, en effet, la langue de l'école) : pour une raison si prompte c'est l'unique moyen d'être amenée à se comprendre d'abord elle-même face à ses assertions dogmatiques" - destacando a constrição da linguagem do ensino submetida ao tom popular (v. DERRIDA, 1990, p. 72)]. Mas se os pedantes supõem dirigir-se ao público (dos púlpitos ou em escritos populares) mediante a termos técnicos exclusivamente concernentes às escolas, o filósofo crítico não é mais responsável por isso do que o é o gramático pela insensatez daqueles que produzem sofismas com as palavras (logodaedalus). Nesse caso o ridículo só toca ao homem, não à ciência" (KANT, 2003, p. 52, grifos e comentários entre colchetes meus). Mais adiante, na próxima seção desta tese, veremos como esse medo advindo da vinda do outro é pensado por Derrida (notadamente em A Besta e o Soberano) como o modelo arqui-pedagógico seminal da filosofia e seu porvir terrorismo do terror ecoado no saber como e no bem saber do fazer conhecimento.

${ }^{112}$ Ibid., p. 45

113 Idem.
} 
noções caras à linguagem filosófica do direito à verdade, especialmente a verdade sobre o "falso, errôneo, imprudente, indesejado""114.

Esse é o direito estrito (das stricte Recht) que se segue na nota do parágrafo E, da Doutrina do Direito, de Kant: a discursividade estrita - e reta de se falar a verdade.

Direito é somente rigoroso [strict], somente alcança sua própria
restrição, na medida em que é contraignant [que pode ser
traduzido tanto como restringido quanto como atraente],
exigente, mas também na medida em que ele atrai
[contraignant] uma "restrição mútua universal" com a
"liberdade individual" e de acordo com esta "lei universal
externa", isto é, natural. Este valor de externalidade distingue o
puro direito da moralidade. O direito não tem interioridade;
seus "objetos" (objekte) devem mostrar-se em ações. Este é um
domínio de visibilidade ou teatralidade, sem dobra. Mesmo
quando uma certa interioridade é chamada ou notificada a
aparecer (questões de veracidade, remorso, da conviç̧ão
profunda, celular etc.), assumimos que ele pode ser
completamente exposto - em um discurso ou gestos
expressivos. Esta externalidade do estrito e puro direito não é de
forma alguma "misturada" com "uma exigência de virtude" 115 .

Nessa passagem, nota-se que Derrida abre uma brecha em Kant para recolocar a questão de rigor, neste caso, de estrito direito a partir da questão da ipseidade, própria da noção de liberdade individual. O direito só é estrito, exerce sua coerção na medida em que conjugado com alguma noção de autossoberania daquele que por direito e por defesa usa de tal força. Essa seria uma instância anterior à lei moral ou jurídica, portanto anterior também à distinção entre essas duas leis. Trata-se aqui de um apelo a outro rigor, a outra noção de estrito direito pensada pela desconstrução, pois essa mesma autossoberania é marcada por uma coerção à externalidade e pelo imperativo categórico de universalidade do "qualquer um" kantiano.

Kant define o "estrito direito" como: "a possibilidade de uma mútua e completa restrição de acordo com a liberdade de qualquer um seguir as leis universais" ${ }^{116}$. A analogia entre direito e retilinearidade é ao mesmo tempo restritiva e pedagogicamente condicionada a uma demanda externa de

\footnotetext{
${ }^{114}$ Idem.

${ }^{115}$ Ibid., p. 46. [Comentários meus].

${ }^{116}$ KANT apud DERRIDA, 2002, p. 47.
} 
universalidade, que conduzirá Derrida a dizer: "Se alguém tem o direito de exigir o pagamento de uma dívida, ele não é dado na medida em que ele pode persuadir a razão do devedor, mas na medida em que ele pode restringi-lo [peut le contraindre], de maneira compatível com a liberdade de cada um 'seguir uma lei universal externa", 117 , portanto: "o direito e a faculdade de obrigar [contraindre] são uma e a mesma coisa" $"$.

Chega o momento apropriado para o segundo desvio, para pensarmos ainda essa universalidade do direito e a soberania de um si ou de um qualquer um.

II.

Em Vadios (2009), Derrida nos diz que a força que resiste pela denegação do outro é a razão do mais forte ${ }^{119}$. A soberania autoimune, a circularidade do si da ipseidade [notemos outra vez a cadeia em que o pse de ipse não se deixa dissociar de poder e hospitalidade: “hostis, hospes, hosti-pet, posis, despotes, potere, potis sum, possum, pote est, potest, pot sedere, possidere, compos etc." $\left.{ }^{120}\right]$, é incondicional ao direito dos mais fortes. É preciso evitar o outro, desde o mais próximo até o mais alhures, propor-lhe escalas de distâncias, de modo a poder calculá-lo, vê-lo vir como um horizonte visível. Uma soberania de Estado ou de "qualquer um" mais forte sempre implicaria, portanto, numa relação de domínio e supressão de poder. O soberano, que Carl Schmitt marca numa só sentença como "quem decide na exceção" ${ }^{121}$, exerce seu poder de soberania sempre nesta incondicionalidade: a circularidade do poder exercer o

\footnotetext{
${ }^{117}$ DERRIDA, 2002, p. 47.

${ }^{118}$ Idem.

${ }^{119}$ A questão da soberania atravessada pela noção de razão do mais forte - " "a razão do mais forte é sempre a melhor" - é trabalhada mais diretamente por Derrida em Vadios (2009), mas atravessa outras obras como O Monolinguismo do Outro: ou a Prótese de Origem (2001), A Escritura e a Diferença (2009) e Políticas da Amizade (2003).

${ }^{120}$ DERRIDA, 2001b, p. 27.

${ }^{121}$ Em Political Theology, Four Chapters on The Concept of Sovereignty, Schmitt abre o primeiro capítulo da seguinte forma: "Soberano é quem decide na exceção. Somente essa definição pode fazer justiça a um conceito limítrofe [borderline - que poderia ser traduzido também como incerto]. Contrário à imprecisa terminologia que é fundada na literatura popular, um conceito limítrofe não é um conceito vago, mas pertencente a uma esfera mais externa. Essa concepção de soberania deve, portanto, ser associada com um caso limite [borderline case], e não com a rotina. Logo deixarei claro que a exceção deve ser entendida como um conceito geral na teoria do Estado, e não apenas como uma construção aplicada a qualquer decreto de emergência ou estado de sítio" (SCHMITT, 2005, p. 5). [Comentários meus].
} 
poder sobre o outro já num léxico dado pelo outro, ou melhor, num certo jogo de condicionalidades que define o limite do Estado como exceção.

Essa é a razão de força forte do soberano, sua soberania incondicional, o eu posso, indivisível ao tempo, de exceção do limite de sua força ainda quando os limites das condicionalidades, que garantem sua força, forem rompidos [o estado de exceção]. É importante lembrar que Schmitt também adverte que a noção de exceção não deve ser confundida como rotina, tampouco como um dispositivo de emergência. Ela é um conceito geral de Estado, senão um conceito limite de Estado: é a sua própria circularidade de se manter em exercício. A soberania do soberano é, portanto, esse poder de posse, de autorização ou de direito de um eu posso.

Para Derrida, esse fantasma da soberania excede à teoria de Estado de Schmitt. É também o exercício da ipseidade que agencia a permanência de valores clássicos como o de liberdade e autodeterminação, que, por sua vez, são exercidos no direito de reunião, da formação de um corpo social, de representação de si [o poder dizer eu], "um viver junto", a "reunião soberana e reapropriativa de si”, anteriores à estrutura de Estado ${ }^{122}$.

Haveria aí outra soberania de uma incondicionalidade mais radical que é a vinda do outro, a externalidade do que vem ou o sim do porvir. Essa incondicionalidade, para Derrida, seria de uma força fraca: o evento (a chegada ou a vinda do que vem ou de quem vem) sem a antecipação que partiria o outro modelo de soberania, a princípio indivisível.

Uma tal partilha supõe também que se pense ao mesmo tempo a imprevisibilidade de um evento necessariamente sem horizonte,

\footnotetext{
${ }^{122}$ É por isso que para Derrida, em vez de se abrir mão da noção de soberania, deve-se desconstruíla, pois é o que nos encoraja a permanecer em luta e resistir à força do mais forte. E aqui concordo com Maíra Matthes, que em seu artigo "A Soberania Fraca", a respeito da desconstrução de Derrida, diz: "Esses 'princípios clássicos' parecem poder ser genericamente resumidos na noção de ipseidade como a força ou o poder de retornar a si mesmo, se autodeterminar. Eles estariam condensados na curtíssima frase: 'Eu posso'. (...) A ipseidade se inscreve no discurso mais amplo sobre a 'emancipação', que Derrida acredita ser crucial na cena política e apenas abandonado a partir das 'piores cumplicidades.' Derrida diz: 'Nada me parece menos perempto do que o clássico ideal emancipador. Não se pode tentar desqualificá-lo hoje, de modo grosseiro ou sofisticado, sem pelo menos alguma leviandade e sem estabelecer as piores cumplicidades'. De modo ainda mais afirmativo, Derrida reafirma a importância das promessas clássicas emancipadoras 'em todas as áreas do mundo e da sociedade'. Sem que essas 'promessas emancipadoras' sejam feitas, a chance de que elas sejam reformuladas, desconstruídas e modificadas também não existiria - o que poderia servir como álibi para o exercício de uma soberania pura e sem prerrogativas. Isso porque na ausência de tais 'princípios clássicos' a necessidade de se pedir perdão por não cumpri-los também não se colocaria” (MATTHES, 2012, pp. 147-148).
} 
a vinda singular do outro e consequentemente uma força fraca. Esta força vulnerável, esta força sem poder, expõe-se incondicionalmente ao (que) ou a quem vem e que vem afetá-la. A vinda desse acontecimento excede a condição do domínio e a autoridade convencionada do que se chama $<<$ performativo $>>$. E transborda então também, sem lhe contestar uma certa pertinência, a distinção útil entre "constativo" e "performativo". E com ela tantas outras distinções conexas, a começar pelas da razão teórica e da razão prática, da ciência e da técnica etc. ${ }^{123}$.

A força fraca vinda do outro, que nos apresenta Derrida, não se refere à efetivação ou não de um ato/efeito intencional, se feliz ou infeliz na perspectiva performativa do pensamento de Austin (1990). Tal força do evento que vem sem antecipação é fraca porque não autoriza nenhuma soberania, não exerce nenhum poder sobre o outro, não resguarda nenhum autor, nenhum efeito de um em si ou sentido próprio; não é uma força de um sujeito, vinda da ação de um sujeito. Sua força vem como um acontecimento, digno de nome. Vem sem deixar ver vir, sem horizonte, pois só há acontecimento ali onde não há horizonte. "O acontecimento, se houver um e for puro e digno desse nome, não vem diante de nós, ele vem verticalmente: pode vir de cima, do lado, por trás, por baixo, ali onde os olhos não têm alcance antecipatório ou preensivo ou apreensivo" "24. Cai sem antecipação, não chega à frente, nem prende, nem apreende como uma força fraca, porém ainda exasperadora. O exaspero advém da vinda desse movimento de força que não se anuncia de frente, não vem de uma tomada de decisão nem de um tratado de condições. Ela é a condição anterior às condições: a vinda do outro radical, que pode vir desorganizar uma casa, fazer tremer aquilo que chamamos de casa ou de linguagem. É somente sob essa incondicional restrição, sob o medo dessa restrição individual advinda da vinda do que vem por vir que organizamos as demais condições, leis morais ou jurídicas.

Pensar no acolhimento incondicional dessa força fraca daria espaço, mutualmente, ao que Derrida (2009) chama de razão por vir e de democracia por vir como uma khora à chegada do outro. A khora, noção cara para a desconstrução, seria essa outra espacialidade que acolheria "sem pertencer àquilo a que dá lugar, nada dando e nada dando de outro, ela daria lugar" ${ }^{125}$. Um espaço

\footnotetext{
${ }^{123}$ DERRIDA, 2009c, pp. 34-35.

${ }^{124}$ DERRIDA, 2012, p.71.

${ }^{125}$ DERRIDA, 2009c, p. 36.
} 
de direito, de política ou de ética do porvir, "ainda heterogêneo e rebelde, irredutível ao direito, ao poder, à economia da redenção"126. Eis o sim, o restrito ou incondicional direito, a pensar que escapa ao esquema da visibilidade e objetividade.

$\mathrm{Na}$ última seção sobre o privilégio do direito à filosofia, intitulada “Objetividade, Liberdade, Verdade, Responsabilidade", Derrida propõe o que poderíamos chamar aqui de mundo das luzes por vir ${ }^{127}$ :

(...) uma topologia paradoxal cujos lugares nunca são completamente expostos. Sem sinopse, sem intuição, sem discurso simplesmente diante [en face] dessa coisa. O conhecimento a que essa topologia paradoxal se refere (história ou ciências sociais intelectuais, instituições culturais, educacionais e acadêmicas, especificamente aqui da instituição filosófica) deve lutar por essa tradição "kantiana" e submeter-se à sua axiomática [Derrida está se referindo, acredito, à lei universal da exterioridade, de seu porvir]. $\mathrm{O}$ gesto "pragmático" desse conhecimento é necessariamente ambíguo, ambivalente, retorcido [ou seja, de outro rigor não oposto à obliquidade]. Deve simultaneamente criticar e exagerar seu "objeto", reinstituí-lo por desconstituir a sua genealogia. Meu próprio discurso não pode escapar completamente à lei desse espaço, mesmo que ele tente vislumbrar um outro filtro de luz ou mais precisamente deixar se infiltrar por um brilho que já vem de fora e passa por tantas rachaduras ${ }^{128}$.

Essa topologia paradoxal, a que nos convoca Derrida, ao mesmo tempo não abre mão da herança kantiana e quer dar espaço a um mundo de luzes por vir; luzes retorcidas por muitas rachaduras, sobretudo a que delimita o valor ético de uma verdade objetiva e da afirmação do valor científico. Não se trata de negar a forma de verdade da ciência, mas restituí-la/restringi-la à sua condicionalidade universal, com objetividade para tal. Derrida nos convoca uma responsabilidade que é também um direito ao "direito de resposta" a essa condição de objetividade que oferece um horizonte como limite do pensamento; essa objetividade que é “interpretada como a 'ética', que é a relação lúcida e livre ao que deve portanto ter a forma, o local, o estado, a identidade, a estabilidade visível, confiável,

\footnotetext{
${ }^{126}$ Idem.

${ }^{127}$ Faço analogia ao título dado à segunda parte do livro Vadios (2009), “O 'Mundo' das Luzes Por Vir", que não pude abordar aqui de forma mais detalhada por uma questão de tempo e desvio. Porém retomarei o texto mais adiante, na sexta seção desta tese, para pensar questões éticopolíticas da razão por vir.

${ }^{128}$ DERRIDA, 2002, p. 63. [Grifos e comentários meus].
} 
disponível e calculável do objeto" ${ }^{129}$. A pragmática ambígua, ambivalente, retorcida dessa resposta, dessa outra ética da desconstrução de Derrida, busca constranger o habitus da "objetividade" - que até mesmo em Kant só ganha tal forma ou cálculo se restrita a uma exterioridade universal - sem que para isso se crie uma nova ordem ou razão estrita de objetividade. O gesto é do sim, do deixarse "infiltrar por um brilho que já vem de fora e passa por tantas rachaduras".

Apesar das aparências, estas questões não são abstratas. De passo em passo, elas atravessam toda a história, a política (a ideia de democracia), o direito e a moralidade, a ciência, a filosofia e o pensar. É, de fato, uma questão de conhecimento, ainda, mas, antes de tudo, de saber como, sem renunciar às normas clássicas de objetividade e responsabilidade, sem ameaçar em causa a crítica ideal da ciência e da filosofia, $e$ portanto sem renunciar o saber, pode-se ainda perseguir essa demanda por responsabilidade. Até que ponto? Sem limite, é claro, porque a consciência de responsabilidade limitada é uma "boa consciência"; mas, antes de tudo, até o ponto de se questionar estas normas convencionais e a autoridade deste ideal, o que quer dizer abrir-se ao exercício de uma espécie de direito de "direito de resposta", pelo menos na forma de uma "questão de volta" em que se liga a responsabilidade ao responder. Em seguida, até o ponto de se perguntar a questão em que se funda, ou melhor, se engaja [engages] o valor da interrogação crítica que não pode ser separado da responsabilidade. E saber pensar de onde vem esse conhecimento - o que podemos e o que devemos fazer com $\mathrm{ele}^{130}$.

É no momento dessa turbulência de objetividade, de um certo estilo de rigor, de ir direto a uma questão ou objeto que o right to philosophy começa a dizer sim ao right to dance. Antes mesmo da constituição de um objeto ou campo, ou da necessidade de ser-objeto ou ser-campo, ou, ainda, do problema de um certo filósofo que se vê bailarino diante do espelho, a dança e a experiência dançante, sistemática e historicamente, estão marcadas pela ausência de ter que ser um objeto ou de reunir determinados objetos, pertencer a um campo - nem mesmo que esse seja o campo da arte, ou de uma estética, pois não esqueçamos que a tradição dessas instâncias, arte e estética, tem-se muitas vezes limitado, notadamente, à pintura, à música, ao teatro e à poesia.

\footnotetext{
${ }^{129}$ DERRIDA, 2002, p. 64.

${ }^{130}$ Idem, p. 66.
} 
Como sabemos, é desconhecida qualquer tradição estética que tome restritamente a dança como objeto. Nem a de Kant, Hegel, Adorno etc. Há um certo apagamento da dança nesse horizonte, não por pura negação, mas sobretudo - quero pensar que sim - por uma impossibilidade de certa objetividade, de certo rigor, advinda da sua materialidade e espectralidade não objetal; o seu problema como rastro ${ }^{131}$. Nem mesmo a autofundação da dança como campo de conhecimento na universidade [se é que podemos ainda chamar de autofundação o processo dessa chegada já dentro de um sistema de leis da universidade moderna, que tem em seu fundamento a previsão da criação e legitimação de novas áreas de conhecimento], como campo guardado e gerido por agentes da dança que tomam a dança como objeto - arqui-escritura de que também faço parte como artista, professor, estudante - atravessado por uma história sistemática de mudança de posições e de reinvenções de suas próprias leis, está imune a tal condicionalidade incondicional.

Esse direito que se exerce ao pensar a dança tenta responder a essa outra força. Pois a dança que cai no piscar dos olhos, como um acontecimento, que chega sem avisar, é também uma força fraca - e essa afirmação pode parecer frustrante para algumas pretensas virilidades soberanas que assombram os ávidos corpos que dançam. Aquilo que acontece como dança dá-a-pensar a dança, está além do que vejo vir - calculado e calculável pelo e para o aparato da percepção. Tal brecha de pensamento deixa escapar que o dá-a-pensar pela dança pode estar além de um pôr-se diante de uma obra que se anuncia como tal. Demanda outra hospitalidade que não a do visível e sua dis-posição - limitada - da visibilidade de uma dança que se põe na objetividade ou na subjetividade. Posso chamar de pensamento aquilo que vem elipticamente me tomar como dança, inscrever a experiência como dança e escapar à maquinaria e destinação de seu evento. O sim ao sim que dá-a-pensar tal movimento. Sim, Sim ao pensar.

\footnotetext{
${ }^{131}$ Por esse motivo, pensar, num só lance, o direito à dança e o direito à filosofia, com Derrida, encontrará ainda essa feliz correlação. Como apresento na quinta seção desta tese, é com o rastro da dança que Derrida irá pensar, notadamente em Chorégraphies (1992), a potência do movimento de mulheres que causam "uma certa turbulência no pequeno espaço filosófico europeu", marcado pela tradição dos homens da filosofia e seu rigor de atribuição de lugares, objetos e coisas.
} 


\section{3 \\ Escrever e Seguir Danças com Derrida Para Além de Derrida}

A imediatez é derivada. Tudo começa pelo intermediário, eis o que é "inconcebível para a razão".

Derrida, 1973.

Uma vez que Derrida pouco escreveu diretamente à dança, e que quando o fez foi sempre de maneira muito tortuosa, ou oscilante, por que ainda investir na relação dança e desconstrução? Se é também reconhecido que quando Derrida se aproximou mais estreitamente da dança, citando diretamente a palavra dança e se demorando sobre ela, foi através de suas leituras de Nietzsche, Marx e Artaud, mas sem jamais recorrer a nenhuma obra específica ou a um movimento histórico de dança, por que ainda insistir nessa leitura de segunda mão ${ }^{132}$ ? "Why not going straight back to Nietzsche? ${ }^{133}$ " [Por que não ir direto a Nietzsche?], me perguntou Jean-François Côté ${ }^{134}$, no $9^{\circ}$ Encuentro Hemispheric Institute of Performance and Politics ${ }^{135}$, que tomou lugar na Universidade de Concordia, em Montreal, em

\footnotetext{
${ }^{132}$ Para um rastreamento da aparição e do uso enigmático da dança, ou melhor, da palavra dança em Derrida, v. Le Thêátre de la Cruauté et la Clôture de la Représentation (1967), Forcener le Subjectile (1986), Eperóns, les styles de Nietzsche (1978), Chorégraphies (1992) e Spectres de Marx (1993).

${ }^{133}$ Possivelmente, naquele episódio original, nossa conversação deve ter se dado entre inglês e espanhol, cheio de muitos gaps devido à minha ainda inabilidade de apresentar minha pesquisa toda em inglês com segurança. Por ter maior facilidade com o espanhol, sempre prefiro falar o idioma de proximidade latina. Porém a citação que faço aqui é de um e-mail trocado com JeanFrançois Côté entre os dias 08 e 09 de dezembro de 2014, quando reencenamos o episódio, e para reinscrever a gagueira incondicional de se falar a língua do outro, preferi manter a conversação em inglês.

${ }^{134}$ Jean-François Côté é professor do Departamento de Sociologia da Université du Québec à Montréal. É também codiretor do Grupo Interuniversitário de Pesquisa sobre as Américas (Gira) e editor da série Americana. Foi bolsista Fulbright na Kennesaw State University, em 2012, e professor visitante na França, na Áustria, no Brasil e no México.

${ }^{135} \mathrm{O}$ Encuentro é realizado pelo Hemispheric Institute of Performance and Politics (Hemi), da NYU, a cada dois anos, em cidades diferentes nas três Américas, reunindo artistas, ativistas, estudantes, pesquisadores e professores interessados na relação entre performance e política, acolhendo uma programação em quatro idiomas (espanhol, inglês, francês e português). Participo de diversos eventos do Hemi, desde o ano de 2010. Foi também no Hemi, juntamente com o Departamento de Performance Studies da NYU, que fui acolhido nos anos de 2014-2015, como visiting scholar, durante meu estágio doutoral no exterior via PDSE-Capes.
} 
junho de $2014^{136}$. Não terá sido essa a primeira vez que me fora questionada a insistência na relação dança com Derrida, mas esse episódio singular ainda foi marcado pela resposta que dei sem demora: It's about love... Derrida haunts myself ["É uma questão de amor... Derrida me assombra/obsidia/infesta" - e notemos, por favor, esse tom de atração como afecção teórica que excede à trivial noção de afinidade]. Apesar de já ter ouvido outras vezes questões muito parecidas, esse episódio parece-me reservar um tom que merece a atenção desta tese. E como traduzir esse tom? Como se traduz o tom de um pergunta?

Apesar de já me ter demorado bastante, na seção anterior, nesse movimento que se toma por direito de ser retilíneo, como uma ética pressuposta que precisa desaparecer para seguir movendo-se, quero pedir licença aqui para responder à questão de uma outra maneira. Falarei, estrategicamente, em um outro tom, numa outra cena.

Decidi retornar a Côté. Por e-mail ${ }^{137}$, solicitei que reformulasse a questão - agora com mais tempo, num outro tempo, uma vez que não restava nada mais do que memórias difusas, espectrais que retornavam para cobrar uma dívida, uma resposta; e, como todo espectral parece ser, o seu retorno era ainda muito penumbral. Reinvocar uma pergunta que obsidia sempre reserva uma reencenação dos pontos cegos, cometendo-se o risco, por vezes, de fenomenalizar projeções vindas da obsessão.

Para não repetir o jeito de reencenar uma pergunta, eu enviei a solicitação num e-mail telegráfico: (...) but as I don't remember more what was your asking, I would like to ask for you to reformulate it here. Could you do it? Do you accept to dance with me? [(...) mas, como não me lembro mais qual foi a sua questão,

\footnotetext{
${ }^{136}$ A pergunta me foi endereçada após a comunicação do meu trabalho Para Além do Ver, Composições Políticas, no grupo de trabalho Inscription/Representation: Theoretical and Creative Approaches, coordenado por Ángeles Donoso Macaya, José Pablo Concha e Silvia Spitta, aos quais agradeço aqui toda a hospitalidade de seu grupo, mesmo sendo eu muito estrangeiro ao mundo da fotografia, principal área de interesse do GT [hospitalidade reservada não somente à minha pesquisa, pois o GT Inscription/Representation se caracterizou como um espaço transversal de proposições, acolhendo outros projetos de dança, cinema-documental, teatro e ativismo interessados em discutir questões acerca do problema da inscrição e representação]. Em especial, agradeço a Ángeles Danoso Macaya, que desde o frutífero Encuentro tornou-se uma importante interlocutora e amiga na cidade de Nova York.

${ }^{137}$ Todas as conversações entre mim e Côté aqui citadas ocorreram por troca de e-mails, em 2014.
} 
gostaria de pedir-lhe que a reformule por aqui. Você poderia? Aceita dançar comigo?].

Côté respondeu:

I couldn't remember the exact phrasing, but it was probably about the highly significant reference to dance in Nietzsche's Zarathustra, together with his basic and revolutionary idea of the Dyonisiac foundation of tragedy in The Origins of Greek Tragedy. The importance given to the body - and to movement - in his whole philosophy is something that leads us beyond the logocentrism that Derrida criticizes, and so the phrasing of my question was probably something like: "Why not going straight back to Nietzsche?" Or something close to, and as simple a formulation as, that... I hope that helps... even if I'm not sure that makes me a dancer! [Os grifos são meus, $S A]$.

Eu não conseguiria lembrar a formulação exata, mas provavelmente era sobre a referência altamente significativa à dança que Nietzsche faz em Zaratustra, juntamente com a sua ideia básica e revolucionária da fundação dionisíaca da tragédia, em A Origem da Tragédia Grega. A importância dada ao corpo - e ao movimento - em toda a sua filosofia é algo que nos leva além do logocentrismo que Derrida critica, e assim a formulação da minha pergunta foi, provavelmente, algo como: "Por que não ir direto a Nietzsche?". Ou algo perto e simples como essa formulação, que... espero que ajude... mesmo se eu não estiver seguro de que isso faça de mim um dançarino! [Os grifos são meus, SA].

Reencenei uma pergunta. Acabei de refazê-la. Estou outra vez obcecado por uma pergunta, ainda que de outra maneira. A fábula, a repetição de um gesto de modo fabuloso, retorna em giros. Dessa vez, convido o interlocutor a dançar comigo, mesmo, como declara Côté, ele não estando seguro de que se torna um dançarino ao reformular sua questão ou ao atender ao meu apelo. Lembremos que condicionei meu apelo a um convite de dança - se, ao atender a um convite, sob tais circunstâncias, aquele que aceita é desde aí um dançarino [e notemos que Côté não diz não estar seguro da ocorrência da dança já condicionada por minha pergunta, mas, sim, se ele pode ser um dançarino]. Não saberemos exatamente qual gesto proferido por Côté não o permite estar seguro de ser capaz de torná-lo um dançarino. 
Retornar a esse telegráfico diálogo só multiplicará as distâncias — já podendo dizer disTanz — que o nosso inglês sofre com o background do latim ${ }^{138}$. Outra vez: “(...) Ou algo perto e simples tal como essa formulação, que... espero que ajude... mesmo se eu não estiver seguro de que isso faça de mim um dançarino!". Chamo atenção para esse gesto que não é o mesmo, não pode ser o mesmo, e que oscila nessa reformulação de uma pergunta, reencenação, como algo perto e simples. Côté se mostra solidário e ainda duvidoso ao meu convite a distância, reformulando o episódio, sem violar o segredo instaurador da dança que já fora lançado e que ainda não sabemos, nem saberemos, se é capaz de transformá-lo, então, em um dançarino.

Respondi a Côté:

(...) Thank you for reply. Yes, it helped me a lot. Actually, we cannot remember exactly what happen that day. Remembering is always a kind of replacement that we never know where. Reenactment is always a change of place... Maybe, that cannot make us dancers, but (maybe yet) some dance happens there.

[(...) Obrigado pelo seu retorno. Sim, me ajudou muito. Realmente, não podemos lembrar exatamente o que aconteceu naquele dia. Lembrar é sempre um tipo de deslocamento/substituição que nunca sabemos onde. Rememorar é sempre uma mudança de lugar... talvez, isso não nos faça dançarinos, mas (ainda talvez) alguma dança aconteça aí].

Esse diálogo nos lança outra vez para questão do "posso estar dançando quando escrevo sobre dança?", que parece fazer tremer certa topo-ontologia na dança (o quando e onde começa... uma dança), mas ao mesmo tempo não consegue desviar-se plenamente dela nem, ainda, de seu suplemento: como garantir a possibilidade de um sujeito dançar? Entre mim e Côté, possivelmente restam dúvidas se aquilo que dança é necessariamente um sujeito ou até um bailarino. Três movimentos precisam ser considerados.

I.

\footnotetext{
${ }^{138}$ Em nossa troca de e-mails, Côté, atento ao meu pedido de desculpas por eventuais erros na gramática inglesa escrita, me acrescentou, solidário: “(...) and please don't worry about your written English - mine suffers also from a Latin background" [... e por favor não se preocupe com seu inglês escrito - o meu também sofre de um background latino].
} 
É preciso marcar a repetição do apelo de rastreamento de origem de quando e onde Derrida ou Nietzsche começaram a dançar, que está também na hierarquização marcada no ir direto a Nietzsche [“... why not going straight back to Nietzsche?"], este último que, segundo Côté, já teria nos levado além do logocentrismo criticado por Derrida. É preciso retornar a Nietzsche outra vez para irmos além de novo, aponta Côté. Há nesses apelos um certo jeito de operar e sistematizar aquilo que se deseja produzir no espaço acadêmico, que põe em questão como fazemos filosofia e dança na universidade e fora dela, e aqui me parece imprescindível gastarmos o devido tempo se desejamos pensar uma filosofia com dança por vir.

Ficção de origem e origem como ficção, eis o problema que conecta e atravessa esses dois campos aparentemente tão distantes: dança e filosofia. A necessidade do apelo ao onde e ao quando há dança em Derrida ou Nietzsche, e a hierarquização de tal decifração, primeiro em um e depois no outro, não está desconectado ao modo como o onde e o quando há inscrição filosófica ou, mais radicalmente, a toda escritura que nos conduza a uma metafísica da presença tal como pensada pela desconstrução derridiana.

Em Gramatologia (1973), Derrida enceta o problema da inscrição da origem e também da cumplicidade das múltiplas origens como anterior a toda produção de episteme, sem o qual não se poderia interpelar nenhum "que é?". Nenhuma origem tem força nem sentido se não iterável, o que não significa a repetição de uma origem em si, mas, sim, com um roteiro de retornar ao retorno, um certo caminho (methodos) a lugar algum, como se na origem não houvesse nada mais que a Necessidade de retorno à origem. Diz o autor: "Pode-se denominar arquiescritura esta cumplicidade das origens. O que se perde nela é, portanto, o mito da simplicidade da origem. Este mito está ligado ao próprio conceito de origem: à fala recitando a origem, ao mito da origem e não apenas aos mitos de origem" ${ }^{139}$. Essa arquiescritura da desconstrução derridiana, que é também o pensamento do rastro como "a marca da ausência de uma presença, sempre já ausente presente", nos diz Spivak - e "sem nostalgia por uma ausência perdida" - , "da falta na origem que é condição de pensamento e experiência"140,

\footnotetext{
${ }^{139}$ DERRIDA, 1973, p. 117.

${ }^{140} v$. SPIVAK, 1997, notadamente, pp. xvi-xix.
} 
junta as mais diferentes mãos na repetição de uma fixação pela origem, a qual, sim, acontece, só pode acontecer, quando já no jogo múltiplo citacional.

Seguindo essa arquiescritura, um certo privilégio filosófico de pergunta, outra vez, tomaria lugar: Que é dança? Pelo que ela se reconhece? Qual certeza de essência deve guiar o levantamento empírico em Nietzsche ou Derrida? Derrida ou Nietzsche, quem dança primeiro? Quem deve ocupar o lugar de fundação conceitual numa pesquisa de filosofia com dança de fato e de direito?

Direito/direto outra vez. Apelo fundamental ao retorno epistemológico, à repetição de tal retorno, a um modo de retornar — vá direto [straight back to], em linha reta [straight] - que é também um modelo espaço-temporal, em que a linha reserva uma economia de energia, em certa velocidade e ritmo para engendrar a economia acadêmica. Eis a fixação entre a origem e a linha sem a qual não pode haver produção de conhecimento reconhecida a si mesma nem nenhuma epistemologia: uma comunidade que se reconhece a si como conhecimento. A espacialidade da linha oferece ao mesmo tempo a ficção da possibilidade de ir e voltar. Elege-se nessa forma de escrita a organização em estágios de sucessão e hierarquização entre ir e retornar, ao mesmo tempo que a abertura de releitura possibilita a iteração e o deslocamento dos caracteres em espaço-tempo.

\begin{abstract}
Trata-se da escritura por sulcos. O sulco é a linha, tal como a traça, o lavrador: a rota - via rupta - cortada pela relha do arado. O sulco da agricultura, também o recordamos, abre a natureza à cultura. E sabe-se também que a escritura nasce com a agricultura, que não se dá sem a sedentarização. Ora, como procede o lavrador? Economicamente. Chegando ao fim do sulco, ele não volta ao ponto de partida. Dá meia volta ao arado e ao boi. Depois, parte novamente, em sentido inverso. Poupança de tempo, de espaço e de energia. Melhoria do rendimento e diminuição do tempo de trabalho ${ }^{141}$.
\end{abstract}

$\mathrm{Na}$ materialidade oca das múltiplas formas e substâncias inscritivas,

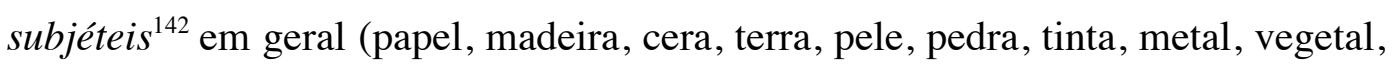
telas, ambientes cibernéticos etc.) - atravessada pela articulação de símbolos cravados pelos mais diversos tipos de instrumento (ponta, pincel, corpos, etc.), a linha que enceta a possibilidade de episteme também deixa escapar o espaçamento, a multiplicação incondicional de outros ocos, portanto outras

\footnotetext{
${ }^{141}$ DERRIDA, 1973, p. 351.

${ }^{142}$ Cf. ANDRADE, 2013.
} 
brechas de inscrição de novos gramas e vozes, onde tal separação já não se encaixilhe, a brecha da diffèrance absoluta. Encetaria toda escritura, mesmo a linear, um "mau infinito, teria dito Hegel, um infinito negativo, um indefinido. Um infinito mau, traduziria Artaud, um indefinido maligno, obsceno, trabalhado pelas forças do mal que ele representa, habitado pelos subpostos e pelos súcubos que ele banaliza sob a neutra superfície"143.

Em sua análise a-histórica sobre a impossível gramatologia como ciência positiva $^{144}$, Derrida (1973) nos mostra como o projeto logocêntrico do símbolo passou a recalcar todas as outras formas de escritura que resistiam à técnica - e eu diria também à coreografia - de certo ritmo linear. Tal instrumentalização da escritura buscava, assim, garantir "uma maior segurança e maiores possibilidades de capitalização num mundo perigoso e angustiante" ${ }^{145}$, mito sem o qual não se ergueria nenhuma arquiescritura ocidental. Pode-se dizer que a linearização é exitosa tecnicamente, mas não consegue barrar o arrombamento incondicional da escritura, incondicionalidade que Derrida chamou de "incompetência da ciência, que é também a incompetência da filosofia, a clausura da episteme" ${ }^{146}$. Como também adverte, tal incondicionalidade não clama por volta à forma pré-científica ou intrafilosófica do discurso, mas, pelo contrário, coloca a diferença-mesma emergida do movimento da escritura na "clausura histórica, isto é, nos limites da ciência e da filosofia" ${ }^{147}$.

O espaçamento, fundo sem fundo sem o qual nenhuma escritura viria à luz, é a figuração da diferença-mesma que explode a instrumentalização da linha. O logocentrismo está na ficção de que tal retidão anula o desvio, recalque que Derrida grifou repetidamente em sua obra. Tal gesto, no entanto, não é uma denegação da linha, tampouco uma afirmação do logocentrismo como patologia, a qual devemos/podemos nos livrar, pois seguir a linha e ser atravessado por ela já é também uma incondicionalidade.

Pode-se afirmar que a desconstrução da escritura, ao mesmo tempo que segue, resiste à linha, pois junta mãos e multiplica os esburacamentos, atravessando ciência, filosofia, arte, religião e todo texto em geral. Tal

\footnotetext{
${ }^{143}$ DERRIDA, 1998, p. 122.

${ }^{144}$ Cf. DERRIDA, 1973, pp. 91-118.

${ }^{145}$ Ibid, p. 106.

${ }^{146}$ Ibid, p. 118.

${ }^{147}$ Idem.
} 
movimento, como Derrida (1973) nos provoca a pensar, sempre esteve em curso, mas somente agora nos deparamos com tal desafio, depois que o sentido de escrita subordinada ao modelo fonético parece não mais dar conta das múltiplas destinerrâncias entre mão e olho, que extrapolam a representação humana e até o sentido daquilo que se afirmou como hierarquia linear manovisual.

Derrida escreve que:

O modelo enigmático da linha é, portanto, aquilo mesmo que a filosofia não podia ver enquanto tinha os olhos abertos sobre o dentro da sua própria história. Esta noite se desfez um pouco no momento em que a linearidade - que não é a perda ou a ausência, mas o recalcamento do pensamento simbólico pluridimensional - afrouxa sua opressão porque começa a esterilizar a economia técnica e científica que, durante muito tempo, ela favoreceu. Desde muito tempo, com efeito, a sua possibilidade foi estruturalmente solidária com a da economia, da técnica e da ideologia. Esta solidariedade aparece nos processos de entesouramento, de capitalização, de sedentarização, de hierarquização, da formação ideológica pela classe dos que escrevem ou antes dos que dispõem dos escribas. Não que a reaparição maciça da escritura não linear interrompa esta solidariedade estrutural; muito pelo contrário. Ela transforma profundamente a sua natureza. O fim da escritura linear é efetivamente o fim do livro, mesmo que, ainda hoje, seja na forma do livro que se deixam - bem ou mal embainhar novas escrituras, quer sejam literárias ou teóricas. (...) começando-se a escrever sem linha, relê-se também a escritura passada segundo uma outra organização do espaço. (...) Porque começamos a escrever, a escrever de outra maneira, devemos reler de outra maneira ${ }^{148}$.

Mas retornemos outra vez à questão de Côté que nos levou a essa perigosa digressão sobre a linha e a origem: por que não ir direto a Nietzsche esse que, segundo Côté, em toda a sua filosofia nos levou além do logocentrismo que Derrida critica? Derrida, que sempre foi muito tributário a Nietzsche, por que insistir nessa filosofia de segunda ordem, tradutória e por vezes parasitária, brisurada e desviante? Por que não ir direto a Nietzsche? Estamos diante então de uma incitação à guerra de nomes próprios, que insinua também a marcar não somente a propriedade dos nomes, como a congeneridade entre dois nomes

\footnotetext{
${ }^{148}$ DERRIDA, 1973, pp. 107-108.
} 
(Derrida/Nietzsche), entre nomes e outros nomes (Derrida/Nietzsche/dança/filosofia).

Antes de falar da questão da propriedade de um nome, é preciso marcar que Derrida (se existe algo a que podemos chamar enquanto tal, atribuir tal nome) nunca está sozinho. Porém evidenciar possíveis cruzamentos entre quaisquer nomes (a propósito, esse tem sido meu trabalho ao longo de todas estas páginas, imbricando mais de um cruzamento, mais de um par) não se amortiza facilmente na ida a um passado (rastro puro) em detrimento de outros jogos de remitência sem o qual não se poderia marcar qualquer grafema. No apelo de regresso a Nietzsche enquanto um desejo de originalidade, subjaz um ímpeto de causalidade linear, o qual falava há pouco. É preciso atentar-se a esse movimento de pureza da origem que muitas vezes assombra como única forma de se lidar com a herança.

Derrida não está sozinho ${ }^{149}$, assim como Nietzsche - este último que se dizia pós-hegeliano e que escreveu a Origem da Tragédia dedicada a seu "mui

\footnotetext{
${ }^{149}$ A tributação de Derrida a Nietzsche quanto ao abalo ao logocentrismo aparece em muitas passagens de suas leituras a respeito da questão da literalidade e o problema do signo, que para forçar outros desvios reencenarei, então, em rodapé. Cito Gramatologia (1973, pp. 22-23): “Aqui, radicalizando os conceitos de interpretação, de perspectiva, de avaliação, de diferença e todos os motivos empiristas ou não filosóficos que, no decorrer de toda a história do Ocidente, não cessaram de atormentar a filosofia e só tiveram a fraqueza, aliás inelutável, de produzirem-se no campo filosófico, Nietzsche, longe de permanecer simplesmente (junto com Hegel e como desejaria Heidegger) na metafísica, teria contribuído poderosamente para libertar o significante de sua dependência ou de sua derivação com referência ao logos e ao conceito conexo de verdade ou de significado primeiro, em qualquer sentido em que seja entendido". Derrida está aqui remetendo à questão da metaforicidade, sobre a qual Nietzsche faz tremer noções de verdade, sentido, ser e sentido do ser, uma vez que essas noções são sempre engendradas por uma cadeia textual metafórica, além de também provocar rasuras nas noções de arte e filosofia, bem como pensador e artista. Mais adiante, Derrida segue em defesa de Nietzsche da acusação heideggeriana de uma ingenuidade sobre "toda uma fundamentalidade oculta sob a aparência de um texto empirista ou metafísico", "uma ontologia que acende a verdade originária", a ontologia do ser. Derrida sugere que em vez de demarcar em ingenuidade reversa quanto à virulência do pensamento nietzschiano, deve-se "acusar a 'ingenuidade' de arrombamento que não pode esboçar uma sortida para fora da metafísica senão utilizando de uma certa maneira, num certo tipo ou certo estilo de texto. (...) Nietzsche escreveu o que escreveu" (ibid., p. 22). Ou seja, aquilo que se chama Nietzsche é também textualidade [e aqui a suposição de Côté, que parece querer encerrar a questão do logocentrismo no regresso a Nietzsche - aquele nos levou além - , sofre um abalo], o que marca a impossibilidade do estar fora da arquiescritura, esse espaçamento fronteiriço, sobre o qual se inscreve o arrombamento, fazendo tremer a estrutura e a própria divisão aquém e além. Derrida enceta ainda que: "os movimentos da desconstrução não solicitam as estruturas do fora. Só são possíveis e eficazes, só ajustam seus golpes se habitam estas estruturas. Se as habitam de uma certa maneira, pois sempre se habita, e principalmente quando nem se suspeita disso" (ibid., p. 30). Essas passagens não afirmam nenhum repouso sobre a estrutura [grifemos aqui a oscilação que Derrida deixa escapar do quando escrevemos "certo tipo ou certo estilo de texto" ou habitamos "de certa maneira"], tampouco nega-se simplesmente a possibilidade de escape. Ao contrário, quer aí fazer pensar outro movimento, o qual não se direciona a um além como horizonte ou caminho a seguir nem se deixa repousar em nenhum apaziguamento topo-ontológico. Essa oscilação inscritiva/arrombadora marca então, outra vez, uma certa dança, um certo estilo, que discutirei mais à frente sobre as coreografias de Derrida (1991) e a questão da baderna.
} 
venerado amigo" Richard Wagner, por vezes embriagado por Dionísio, incorporando ainda outros antepassados, como Zaratustra ["Zaratustra, o dançarino; Zaratustra, o leve"] e Hans Sachs [o poeta]. Esse Nietzsche infestado de outros, conjugadamente, vem assombrar as leituras daqueles que vieram depois (reaparecendo como uma multidão de espectros, não somente em Derrida, mas também em tudo aquilo a que se chamou de geração pós-Nietzsche, sua rede de comentadores, amantes de suas leituras, outros tantos nomes - todos sem os quais pouco saberíamos dessa chamada força original arrombadora). $\mathrm{O}$ original de todo esse nome, Nietzsche, dá-se aí entre enraizamentos dispersos e reunidos em uma temporalidade out of joint ${ }^{150}$. Ir a Nietzsche, seja em qual época for, é sofrer do atraso e do afastamento dele, dessa coisa a que se chama ele, obsidiada e apelada por tantos outros, perseguidor e apelador de tantos outros. Nesse sentido, esta escrita a que chamarei de minha [sem ser minha mesmo] e que está fadada ao desaparecimento entre mãos e bocas de outrem, incondicionalmente, já está atada nesse movimento que sofre de anacronia.

No entanto, o apelo ao regresso a Nietzsche, ir direto a ele, tal como proferido por Côté, parece ainda problemático na medida em que insinua que o seguimento dessa coreografia (em linha reta, a caminho de) restituiria a conclusão de um débito: ir direto a esse que já nos levou além do logocentrismo criticado por Derrida, bastando portanto somente regressar a ele, sem demora (não sem demorar-se em Nietzsche, mas sem demora em chegar a ele, ir, portanto, direto a ele). Na busca por tamanha imediatez, tal apelo coreográfico parece querer desviar a incondicionalidade que toda grafia enceta num texto: a marca de empréstimos dos rastros de uma herança para deslocar [desconstruir] a própria herança ou imprimir a marca da obliteração absoluta sem a qual não há pensamento nem experiência ${ }^{151}$, nem mesmo a possibilidade de herança. Essa é uma força tanto

\footnotetext{
${ }^{150}$ A noção de tempo out of joint é muito importante na filosofia de Jacques Derrida e será tratada na quinta seção desta tese. Ela é tributária a William Shakespeare e Karl Marx e pode ser traduzida de diferentes maneiras. Por ora poderemos pensar nela como "tempo fora dos eixos" ou também como "injunção disjuntiva do tempo".

${ }^{151}$ Estou forçando, em gesto cirúrgico (talhando, raspando, cosendo, descosendo, limando, perfurando etc.), uma tradução desviante da leitura de Gayatri Spivak sobre a questão do rastro em Derrida, em seu prefácio à tradução inglesa de Of Gramatology (1974): "Derrida's trace is the mark of the absence of a presence, an always already absent present, of the lack at the origin that is the condition of the thought and experience" [A noção de rastre de Derrida é a marca da ausência de uma presença, uma desde sempre presença ausente, da falta na origem que é a condição do pensamento e da experiência] (SPIVAK, 1974, p. xvii). Acabo de performar, outra vez, um
} 
nascente como parricida de toda metafísica, a qual Derrida chamou de arquiescritura, de que ainda não fomos, nem seremos, capazes de nos livrar.

A arquiescritura, também marcada por uma arquiviolência [como veremos mais adiante], é a abertura [se preferirem, a clareira] de todo texto, anterior à possibilidade de re-constituição de uma ontologia e todos seus suplementos históricos ou epistemológicos. Eis um primeiro ainda Derrida, respondendo muito apressadamente, sobre a repetição com Derrida (e escrevo com em vez de $d e$ ) nessa escrita. Repito com Derrida e tantos outros que parecem ecoar dessa brecha:

Em sua sintaxe e em seu léxico, no seu espaçamento, por sua pontuação, nas suas margens, a pertencença histórica de um texto não é nunca linha reta. Nem causalidade de contágio. Nem simples acumulação de camadas. Nem pura justaposição de peças emprestadas. E, se num texto se dá sempre uma certa representação de suas próprias raízes, estas vivem apenas de sua representação, isto é, de nunca tocarem o solo. O que destrói sem dúvida a sua essência radical, mas não a Necessidade de sua função enraizante. Dizer que nunca se faz mais do que entrelaçar as raízes ao infinito, dobrando-as até fazê-las enraizar em raízes, passar de novo pelos mesmos pontos, redobrar antigas aderências, enrolar-se sobre si mesmas ou volver-se reciprocamente, dizer que um texto nunca é mais do que um sistema de raízes, é sem dúvida contradizer ao mesmo tempo o conceito do sistema e o esquema da raiz. Mas, por não ser uma pura aparência, esta contradição adquire sentido de contradição e recebe seu "ilogismo" apenas se pensada numa configuração finita - a história da metafísica - presa no interior de um sistema de raízes que não se termina aí e que ainda não tem nome ${ }^{152}$.

Nesse sentido, não estou interessado em desviar dos enraizamentos entre Derrida, Nietzsche e outros nomes, até porque o apelo de Côté (que não se encerra em torno do nome de Côté, nem o de lhe atribui nenhuma propriedade, o que nos faz pensar a insistência desse personagem neste texto como uma repetição fabulosa $^{153}$ ) não insinua tal posição, nem mesmo poderia qualquer texto tomar força sem tais dobragens, redobragens, aderências, costura, ramificação e

movimento de passagem e atravessamento entre corpos, grafemas e nomes que engendram essa arquiescritura.

${ }^{152}$ DERRIDA, 1973, pp. 125-126.

${ }^{153}$ Explicarei melhor tal atribuição mais adiante. 
enlouquecimento de si. Ao contrário, estou levando ao limite o straight back to Nietzsche para pensar o ímpeto de imediatez.

Se Derrida está imbricado numa cadeia suplementar histórica, Nietzsche também o está, assim como toda possibilidade de apelação de um nome próprio.

(...) é porque o nome próprio nunca foi possível a não ser pelo seu funcionamento numa classificação e portanto num sistema de diferenças, numa escritura que retém os rastros de diferença, que o interdito foi possível, pode jogar, e eventualmente ser transgredido, como veremos. Transgredido, isto é, restituído à obliteração e à não propriedade de origem ${ }^{154}$.

Pensar na composição de nomes apropriados à vinculação de qualquer pesquisa, seja ela uma pesquisa de filosofia com dança ou qualquer outra, sempre esbarra nesse limite de apagamento do signo ao passo que se diferencia: o limite do rastro. Nietzsche, Derrida, Hegel, Heidegger, Marx, entre outros, inclusive a possibilidade de se atribuir um eu (até mesmo o eu-Sérgio), estão condicionados a esse limite do rastro. Estamos sempre destinados a "nomear, dar os nomes que eventualmente será proibido pronunciar, tal é a violência originária da linguagem que consiste em inscrever uma diferença, em classificar, em suspender o vocativo absoluto" ${ }^{155}$. Ou seja, a validação de qualquer assinatura - e qualquer sentido epistemológico — não pode escapar a essa destinação da “(...) arquiviolência, perda do próprio, da proximidade absoluta, da presença a si, perda na sua verdade do que jamais teve lugar, de uma presença a si que nunca foi dada, mas, sim, sonhada e desde sempre desdobrada, repetida, incapaz de aparecer-se de outro modo senão na sua própria desaparição"156.

É somente no engendramento dessa arquiviolência que se pode instituir o que poderíamos chamar, ainda com Derrida, de segunda violência, reparadora, a “moral”. Essa é a instância em que o próprio se deixa confundir com o mais apropriado, o caminho do bem, a lei, o nome de direito, que por conseguinte se imbrica com uma terceira violência, a incondicionalidade da não identidade, portanto uma "desnaturação do próprio e a identidade como um momento de abstração" $" 157$.

\footnotetext{
${ }^{154}$ DERRIDA, 1973, p. 134-135.

${ }^{155}$ Ibid., p. 138-139.

${ }^{156}$ Ibid., p. 139.

${ }^{157}$ Idem.
} 
O sujeito — digno de nome - está imbricado nessa arquiviolência, em que a sujeição do sujeito à identidade a si já não é mais desvinculada da incondicional obliteração. "Há escritura desde que o nome próprio é rasurado num sistema, há sujeito desde que essa obliteração do próprio se produz". Portanto, evocar um nome próprio, que, como já vimos, somente se pode inscrever dentro de uma cadeia diferencial (texto), como o nome de um autor (Derrida, que não é Marx, que não é Nietzsche, nem Freud etc.), por exemplo, atribuir-lhe uma afecção enraizante, é também abrir brecha à sua negação, proibição de uso, impropriedade, contestação. Não somente por um não reconhecimento de pertencença ou parentesco ou afinidade entre o teor intelectual do texto e a restituição genealógica do autor citado, como também pela negação/afastamento de sua propriedade desde a assinatura, como a formulação: Derrida está menos apropriado que Nietzsche; Derrida está mais longe, e Nietzsche está mais próximo à dança.

O straight to the point ${ }^{158}$ é assim sempre forçoso. Digo forçoso, pois nem a mais absoluta pragmática consegue se livrar, tão imediatamente, aos movimentos enraizantes de linhas desviantes, pois eles são também condicionantes, grafematicamente, da sua vinda à luz. Mesmo depois de Nietzsche, ainda respondemos em/as suas dobras, ainda falamos em nome de Nietzsche, ainda falamos em tantos outros nomes e através deles (seja nomes para designar assinaturas ou não).

No entanto, o pensamento do rastro resiste a esse caminho da origem, ao compromisso da origem (da busca de uma aliança mais original entre filosofia e dança), aos homens da filosofia que vão direto ao ponto e a esse aprofundar-se na raiz, ir fundo nela, como se não fosse essa coisa que chamamos de raiz para designar pertencença histórica um movimento de superficialização: tessitura de nomes, significantes e grafemas sob a qual afirmamos nos apoiar, na qual nos dizemos acreditar estar localizados. As linhas de tal tessitura são desde sempre brisuradas, dobráveis e também tomadas/emprestadas de outras ou, mais

\footnotetext{
${ }^{158}$ É oportuno lembrar que a palavra straight, do inglês, desliza cotidianamente tanto para a qualificação de identidade de gênero quanto para a atribuição de um comportamento social não desviante. I'm straight tanto pode conotar "eu sou heterossexual" quanto pode descrever uma certeza de decisão, como "estou certo disso", ou ainda um veto à participação em atividades "perigosas", como uso de drogas, sexo ou atividades ilícitas. Observemos esse deslize.
} 
radicalmente, roubadas, extraídas, deslocadas. Dizemos nós (com) nós ${ }^{159}$. Esse empréstimo desviante não se nega simplesmente ao jogo de atribuição de gerações, herança, afinidades teóricas etc. Ao contrário, quer-se-fazer-pensar sobre ele - começando por onde acredita-se estar — e nesse sentido a escolha de Derrida aqui não é um desaviso aos seus antepassados. É com Derrida, talvez pela repetição de seus ecos naquilo que venho tecendo há alguns anos entre dança e filosofia, que tais questões me chegam. Esse nome que se repete sem nenhuma propriedade, sem nenhum desejo de parecer próprio da dança e que talvez [ao contrário do nome de Nietzsche ${ }^{160}$ ] tem sido menos apropriado (no sentido de tomado para si) para se falar de dança.

A assinatura do sujeito se dá na repetição de tal afastamento da presença a si, da proximidade transparente no cara a cara dos rostos e do contato imediato ao alcance da voz, não podendo mais, portanto, evocar a Nietzsche ou Derrida, imediatemente, ir direto a eles, sem termos que nos desviar, iteravelmente, por outras dobras. Se aceitamos tal assujeitamento do sujeito, roubado de si e impróprio de nascença, a pergunta não mais se colocaria entre a escolha de Derrida ou Nietzsche numa pesquisa de filosofia com dança, mas, sim, reivindicaria, oscilantemente, uma problematização da brisura $^{161}$ entre noções de

\footnotetext{
${ }^{159}$ Evocando esse par indecidível que forçarei, a distância, com Bruno Latour, na próxima seção desta tese.

${ }^{160}$ Refiro-me à proliferação repetível da associação do nome de Nietzsche à dança, que mediatiza e memetiza seu nome entre epígrafes, enxertos e coassinaturas de livros, dissertações, teses, papers e hoje pode-se dizer também em tweets, posts, scraps etc. A repetível citacionalidade de passagens como "...e aqueles que foram vistos dançando foram julgados insanos por aqueles que não podiam escutar a música" e “...só acredito num deus que saiba dançar”, além de estudos constantes sobre a relação de Nietzsche com a Dança, é o que autoriza também a indicá-lo como nome mais apropriado para se pensar a dança. Da mesma forma, aqueles que se reúnem em seu nome tentam também resistir a uma certa apropriação desse espectro chamado Nietzsche enlouquecido de si.

${ }^{161}$ Brisura (brisure em francês) é uma noção apresentada por Derrida em Gramatologia (1973) para afirmar que "diferença é articulação", ao mesmo tempo junção e partilha - o que também delineia a noção de différance (com "a") para além do juízo genealogicamente construído de différence como oposição binária. $\mathrm{O}$ artifício do "a" na différance derridiana, essa pequena partícula que aparece sem ser escutada, é crucial para marcar, como um grafo, o rastro da radical diferença pensada por Derrida. O atrito entre brisura e différance afirma a alteridade enquanto processo de margem, espaçamento do "entre", interstício de dissenso, de não-fixidez e de nãoapaziguamento - contrariando a toda possibilidade de síntese e fechamento de sentido ou referente em si. A palavra brisura vem ao pensamento indicada por Roger Laporte, que, por carta, escreve: "Vós sonhastes, suponho, encontrar uma única palavra para designar a diferença e a articulação. Folheando ao acaso o Robert, quiçá eu a encontrei, desde que se jogue sobre a palavra, ou antes, que se indique o seu duplo sentido. Esta palavra é rotura [brisura]: '- Parte fragmentada, quebrada. Cf. brecha, fratura, fenda, fragmento. - Articulação por charneira de duas partes de uma obra de carpintaria de serraria. A rotura de uma veneziana. Cf. Junta"' (LAPORTE apud DERRIDA, 1977, p. 80). Derrida, por sua vez, nos dirá: “A brisura marca a impossibilidade para um signo, para a unidade de um significante e de um significado, de produzir-se na plenitude de um presente e de uma presença absoluta" (DERRIDA, 1973, p. 85). Nesse sentido, podemos entender a brisura
} 
pertencença, epistemologia, genealogia e filiação. Esse tem sido o trabalho que, pensado com Derrida, com sua gramatologia impossivel que quer resistir à metafísica da presença, sugere outras pistas para pensar a dança e as artes do corpo por caminhos para além da constituição de epistemologias. A epistemologia, por sinal, tem sido um atrativo da comunidade intelectual das artes nos últimos tempos, sobretudo no Brasil, no espaço acadêmico, da adequação das artes às normas da instituição acadêmica e seu modelo restrito de pesquisa como afirmação da ciência, ao modo de produção científico.

[É preciso abrir um largo colchete para mencionar que, apesar de identificar ainda pouca ramificação derridiana no campo acadêmico da dança e dos estudos da performance no Brasil, tenho acompanhado nos últimos dez anos algumas iniciativas de artistas e professores interessados em tal diálogo de forma continuada. Se citasse todos aqui, tomaria um desvio muito largo. Porém permitam-me remarcar, mais uma vez (e não mais em rodapé), a minha incondicional tributação a dois desses nomes: Lúcia Fernandes Lobato e Paulo Cesar Duque Estrada.

Lobato, professora da Escola de Dança da UFBA, sempre se arriscou na leitura corajosa, às vezes "independente", da obra de Derrida. Digo "independente" aqui sob rasura, pois isso nunca significou trabalhar sozinha. Lobato foi a primeira professora que me despertou o interesse de pesquisa como trabalho coletivo; trabalho demorado sobre leituras, referências, incorporações/excorporações. Ainda em 2005, quando minha professora no curso de Dança da UFBA, ao ver meu interesse em sala de aula por questões que já anunciavam rastros da desconstrução, acompanhado da recente criação de meu grupo artístico, o Grupo CoMteMpu's, Lobato me emprestou um primeiro livro de um comentador que tratava sobre a noção de escritura em Derrida ${ }^{162}$. O empréstimo era um convite ao debate; iniciamos, assim, os primeiros riscos sobre a obra de Derrida, ainda exorbitantes à comunidade dos "derridianos". Lobato também me acompanhou como orientadora na iniciação científica, no Trabalho de Conclusão de Curso em Dança e no Mestrado em Artes Cênicas na UFBA, além

como diferença que ao mesmo tempo reúne e separa, que enceta e deixa escapar, criando assim uma arquitetura da alteridade como uma rede irredutível de articulações dissimétricas de rastros, grafemas, textos de textos, camadas de camadas e todo etecetera que vai margeando o agenciamento do Outro sempre porvir.

${ }^{162}$ Derrida: a Cena da Escritura (1998), de Cristopher Johnson. 
de ter sido uma atenta interlocutora dos trabalhos do CoMteMpu's. Em todos esses lugares, pude tensionar as primeiras formulações e pistas dessa coisa a que hoje chamo de pensamento que vem dançando, assombrado, sobretudo, por Derrida - mas nunca somente por ele, pois sempre há mais de um espectro.

Já Duque Estrada reserva uma singularidade de ter sido o primeiro nome a fazer um estudo sistemático da obra de Derrida num Departamento de Filosofia no Brasil, notadamente na PUC-Rio. Ele nunca se viu bailarino, mesmo tendo em sua trajetória experimentado alguma dança nos workshops do Grupo Coringa, de Graciela Figueroa, entre o fim dos anos de 1970 e início dos 1980 (os rumores de data nunca são muito claros). Muitos anos depois, me acolheu em seu grupo de pesquisa, Núcleo de Estudos em Ética e Desconstrução (NEED), e também como seu orientando no Mestrado e no Doutorado em Filosofia na PUC-Rio, dizendo sim à vinda da dança para a filosofia. A hospitalidade de Duque Estrada nunca me foi exclusiva, pois essa é a responsividade de seu pensamento que lhe faz acolher outros artistas e pesquisadores de diversas áreas, advindos quase que de paraquedas em suas aulas, com os quais pude conviver na trajetória às margens da filosofia. Eu fui seu primeiro orientando a escrever sobre a relação Derrida, dança e performance, mas ao longo do período que estive em sua companhia como orientando, testemunhei a chegada de muitos pesquisadores e artistas da dança interessados na filosofia de Jacques Derrida.

Como falar das afecções derridianas pelas quais pareço ser tomado sem trazer à memória nomes, movimentos, circuitos acadêmicos, circuitos artísticos, comentadores, tradutores, artistas e outros? Como falar sem já estar engendrado nessa economia do rastro marcado pelos empréstimos, tributações, endividamentos, obliterações, afecções e coerções? Como dançar sem desvios? Os retornos de Derrida na minha trajetória são como o que ele mesmo chamou de "futuridade anterior", uma vinda que vem sempre como "outra vez", mas sempre de maneira completamente diferente, "que resta e resiste como um re-envio ao porvir" ${ }^{\prime 163}$. As idas e vindas dessas restâncias de Derrida, a multiplicidade de

\footnotetext{
${ }^{163}$ Ecos da tradução de Fernanda Bernardo: “O 'futur antérieur', cujo sintagma aqui traduzimos à letra, é o tempo da desconstrução: no seu enunciado contraditório, ele dá conta de um passado absoluto ou de uma anterioridade imemorial que, subtraindo-se a cada passo ao presente sem no entanto se perder, antes restando como aquilo que resta e resiste, ininterruptamente se re-envia para o porvir que, por isso mesmo, Derrida distingue do futuro que, na tradição filosófica, de Aristóteles (Física, IV , 218b) a Heidegger, foi determinantemente sempre pensado por referência com o presente (presente-passado, presente-presente, presente-futuro). O 'futuro anterior' dá assim
} 
citações em tempos e de tempos diferentes, ressaltam aqui o desajuste e a disjunção daquilo que chamamos de experiência.]

Teço aqui circuitos que aderem e escapam ao nome de Derrida, este que declarou certa vez a David Wills ser verdade [essa palavra que já não podemos pensar em sua filosofia sem lembrar a metaforicidade nietzschiana] que "apenas palavras the interessavam" ${ }^{164}$, por razões que têm a ver com sua história e arqueologia, portanto são seu investimento "mais forte, mais antigo" e que lhe produz "mais gozo" do que os investimentos nas artes plásticas, visuais ou espaciais [e talvez a dança apareça ainda mais cega em Derrida]. Mas também são palavras do próprio Derrida, assinadas por ele mesmo, que dizem que as palavras devem ser pensadas desde o corpo, tratadas como "corpos que contêm a sua própria perversidade (...), digamos, a desordem regular das palavras" ${ }^{165}$, movimento este que abre a linguagem para o não verbal. E o amante das palavras ainda arremata dizendo que mesmo para artistas que trabalham com proposições não verbais [se tal coisa for possível de ser formulada]: "há palavras que funcionam neles, quer eles saibam, quer não; eles estão no processo de serem construídos por palavras"166.

Poderíamos, então, formular, relançando o arremate, que há dança em Derrida, quer ele a tenha como amante, quer não; quer sua comunidade de leitores se interessem, quer não; quer seja negada a probidade, quer não; Derrida, assim como todos os nomes que possamos citar, incorporar, deslocar, fazer mover,

conta do contratempo ou da disjunção que afecta o tempo da desconstrução: o instante na sua impossibilidade e na sua espectralidade remanescente" (BERNARDO, 2009 in DERRIDA, 2009c, p. 47, N.T.).

${ }^{164}$ É preciso localizar essa declaração, que foi retomada por David Wills, na entrevista As Artes Espaciais (IN: Derrida, 2012), que ao lembrar das diversas declarações de Derrida sobre o seu amor às palavras, mesmo quando tratando de questões que fogem ao problema do léxico, como a questão do subjétil, ao passo que outros campos não verbais como arquitetura, fotografia e música vinham, em tempo, apresentando cada vez mais interesse em suas obras, interpelou: "qual o lugar do não verbal no seu discurso?". Acompanhemos Derrida: "É verdade que apenas palavras me interessam. (...) Os senhores sabem que eu amo as palavras. Tenho o maior desejo em me expressar em palavras. Para mim isso envolve o desejo e o corpo; no meu caso, a relação do corpo com as palavras é tão importante quanto com a pintura. Essa é a minha história, a história de meus investimentos e pulsões. Sou frequentemente repreendido: 'O senhor só gosta de palavras, é só seu léxico que lhe interessa. O que eu faço com as palavras é fazê-las explodir para que o não verbal apareça no verbal. Quer dizer que faço as palavras funcionarem de uma tal maneira que em certo momento elas não pertencem mais ao discurso, ao que regula o discurso. (...) Ao tratar as palavras como nomes próprios, interrompe-se a ordem usual do discurso, a autoridade da discursividade. E se eu amo as palavras é também por causa da habilidade que elas têm de escaparem à sua forma própria, seja porque me interessem como coisas visíveis, letras representando a visibilidade espacial da palavra, seja como alguma coisa musical ou audível" (DERRIDA, 2012, p. 39).

${ }^{165}$ DERRIDA, 2012, p. 40.

${ }^{166}$ Idem. 
oscilar em seu movimento por vir, pode compor uma dança, sem ser mesmo um bailarino, sem assumir o lugar do sujeito que dança e a profere como tal. Ainda com Derrida.

II.

Pensemos sobre esse bailarino-sem-ser, essa coisa que pode engatar uma dança sem ser seu sujeito de direito. Retomemos André Lepecki, outra vez, em Exhausting Dance (2006), que já nos escreve sobre a possibilidade [incondicional] de distância entre dança e dançarino, especialmente no momento em que ele pensa sobre a relação de Bruce Nauman com a dança, a partir de Dance or Exercise on the Perimeter of a Square (1967-8), entre outros trabalhos. Tomarei essa obra especificamente porque é nela que Nauman, citando "dança" no título do trabalho, cria e executa uma partitura coreográfica, sem ser reconhecido como um dançarino (formado como tal) e sem afirmar-se como participante de uma herança histórica da dança.

Para Lepecki, em Dance or Exercise on the Perimeter of a Square, Nauman usa a palavra "dança” sem sentido critico ${ }^{167}[$ “(...) uncritical usage of the word 'dance" $\left.{ }^{\prime 168}\right]$, tendo o artista declarado em entrevista a Lorraine Sciarra, em maio de 1970, que o contato mais próximo que ele teve com a dança - enquanto linguagem ou campo de formação histórica - foi numa conversa com Meredith Monk, em São Francisco, em 1968. Nessa ocasião, Nauman declarou ter ouvido então falar pela primeira vez em consciência corporal e também do trabalho que Merce Cunningham vinha desenvolvendo contemporaneamente, o qual Monk considerava similar ao de Nauman no que dizia respeito ao famoso manifesto de Cunningham que declarava "qualquer movimento pode ser material para uma dança" ${ }^{\text {"169 }}$. Pensemos um pouco sobre esse uso sem sentido crítico. Seria essa acriticidade um problema da noção de sentido estrito da dança?

\footnotetext{
${ }^{167}$ Notemos essa noção de crítica aqui empregada. Talvez, ela remonte, sem saber, a questão de direito e juízo que vimos discutindo anteriormente, que nos convida a pensar o uso da linguagem sem razão crítica. O que seria esse outro pensamento, esse outro direito de razão sem o estrito senso da crítica?

${ }^{168}$ LEPECKI, 2006, p. 23.

${ }^{169}$ Em seu manifesto, Cunningham, no fim da primeira metade do século XX, declarava: 1) qualquer movimento pode ser material para a dança; 2) qualquer procedimento é válido como método de criação; 3) qualquer parte ou partes do corpo podem ser usadas (sujeitas às limitações naturais); 4) música, figurino, cenografia, iluminação e dança têm cada qual sua própria identidade
} 
Em sua escrita, Lepecki aponta que, por um interesse de manutenção e expansão dos limites do regime estético da dança pós-moderna norte-americana, que precisava restituir e reduzir todos os trabalhos experimentais de dança que emergiram nos anos 1960/70 à Judson Church Theather, em New York, historiadores iniciaram uma verdadeira caça a vestígios e pontos de contato entre Nauman e o movimento da dança norte-americana em expansão. Alguns desses historiadores afirmaram que Nauman teria participado dos workshops realizados pela Judson. Em sua pesquisa criteriosa, Lepecki vai nos mostrar que não há indícios de participação de Nauman no cenário da Judson Church, e sim somente uma declaração por entrevista de que o artista havia se encontrado com Meredith Monk em 1968, em São Francisco, e conversado sobre assuntos próximos daquele universo. Mais adiante, Lepecki ainda afirmará que Nauman introduziu "não necessariamente a dança mas o coreográfico no campo expandido do escultural" ${ }^{170}$, marcando, assim, a possibilidade de ocorrências de método coreográfico em obras que não se afirmam, necessariamente, como parte de um regime de dança.

No limite desse quiproquó histórico, Lepecki expõe a maquinaria sedutora e violenta de formação do regime estético na dança, dos processos de inclusão e exclusão de sujeitos nessa maquinaria, que define o próprio assujeitamento do sujeito como sujeito histórico participante da clausura arquiviolítica metafísica a que me referi em vários momentos nesta escrita. Forçando um pouco mais, Lepecki deixa escapar, por um lado, que outras experiências (aqui empregando o duplo sentido experimental/acontecimental que essa palavra carrega) de dança podem se dar anteriormente à afirmação do sujeito pertencente a uma herança histórica, parental, consanguínea. Por outro lado, também só podemos reivindicar e resistir a tal herança na medida em que já estamos tensionados por ela, em dívida com ela, através de uma língua, incondicionalmente dada pelo outro e ao outro enviada. No jogo entre dação, recebimento e envio de uma herança, estamos sujeitados à possibilidade de substituição de datas, caracteres, aproximação de personagens, tensionamento

e lógica; 5) qualquer dançarino da companhia pode ser solista; 6) pode-se dançar em qualquer espaço; 7) a dança pode ser sobre qualquer coisa, mas é fundamentalmente e primeiramente sobre o corpo humano e seus movimentos, começando com o andar (CUNNINGHAM apud SILVA, 2005, p. 21).

${ }^{170}$ LEPECKI, 2006, p. 32. 
entre eles, multiplicação de distâncias. Só podemos atribuir a possibilidade de um pensamento de dança - mesmo quando não sob judice de uma certa forma de crítica - porque há uma memória histórica e da tradição da noção de obra, e da arte em geral, independentemente de um artista conhecer ou não os trajetos que sua obra engendra ${ }^{171}$.

Um herdeiro não tem necessariamente vínculo consanguíneo direto com os demais portadores da herança. Torna-se herdeiro aquele que recebe, como uma doação ou também um dom, um legado a qual foi convocado a poder responder. Por um lado, com o ensinamento de Arbeau, na dança, poderíamos dizer: dançarinos são aqueles capazes de aprender um bem dançar. Por outro lado, de maneira mais radical, sem evocar nenhuma lição, pois não restitui a nenhum bem saber: dançarinos são aqueles que ativam telecoreografias mesmo sem saber. $\mathrm{Na}$ dança, ter que responder a uma herança não requer aceitação do legado - isto é, se o herdeiro a reconhece como sua ou não a herança que se herda. A telecoreografia é também arquiviolenta, nesse sentido, pois no seu sim radical pode tanto criar rotas de fuga quanto controlar mediações de danças.

Quando Nauman é apontado como um dos herdeiros da Judson Church, passando a habitar uma memória da dança americana, reitera-se uma força da economia de rastros cuja substância comum, o Pai, desapareceu; uma política da amizade fraternal, como pensou Derrida:

(...) a respeito desta fraternidade como partilha equitativa dos restos do pai, da substância comum desaparecida e consumida, a seguir ao desmembramento ("irmãos da partilha do corpo desmembrado") - um desmembramento que, uma vez mais, análogo a um esquartejamento com reapropriação circular da dita substância comum, segundo o luto e a memória, se assemelha então a uma cruz na roda. ${ }^{172}$

A passagem de Derrida se refere à questão do modelo de fraternidade que remonta uma certa tradição cristã ecoante também na noção de partilha da liberdade ou da igualdade incomensuráveis de todo e qualquer um - que Derrida irá tensionar a partir de L'Expérience de la Liberté, de Nancy ${ }^{173}$. Essa manobra nos levaria a uma discussão muito inquietante sobre a lógica de nascimento de

\footnotetext{
${ }^{171}$ DERRIDA, 2012.

${ }^{172}$ DERRIDA, 2009c, p. 128.

${ }^{173}$ Cf. DERRIDA, 2009c, pp. 123-132.
} 
uma filiação ou de uma genealogia e dos roteiros de sua partilha e de sua substância ("o sangue", "o cálice de vinho", "o sêmen”) que mantêm uma certa tradição falogocêntrica na experiência de reunião, nas razões de uma reunião, que na continuidade do nosso percurso até aqui permite-nos, por instante, remeter à noção de abandono na genealogia da coreografia, pensada por Lepecki (2006), e seus laços fraternos com a história europeia do balé.

A figura do pai desaparecido da fraternidade arqui-político-histórica da dança, da manutenção de um certo regime de dança, poderia ser traduzida pelo retorno ao sistema de balé criado por Luís XIV junto ao seu projeto de economia institucional das artes, no século XVII. Antes disso, no século XVI, encontraríamos Arbeou e sua Orchesographie montada como uma máquina desejante para lidar com o abandono do padre e a virtualização do homem-de-lei (o discípulo que é também um advogado), aquele que tem o direito por autorização e por autoridade de um bem saber passar um legado adiante. Quantas figuras falogocêntricas serão necessárias para retomar essa tradição? E poderíamos também nos perguntar sobre a mulher, a questão do feminino nessa genealogia histórica: o que seria da história da dança sem as mulheres? Estamos, desde sempre, replicando ou partilhando o mesmo fluxo de sangue? O jorro? Onde esse fluxo para? Quem pode incorporar telecoreograficamente esses termos?

Este segredo passado de geração a geração que se autoafirma mesmo sem saber, mas que ainda mantém o bem saber como uma técnica, ser bailarino sem o saber ser [talvez seja esse o problema de Nauman - se sua obra pertence ou não a um regime e a uma memória de dança - ou o caso se Côté - se, ao aceitar um certo convite de dança, já se torna um dançarino] nos força a pensar a telecoreografia que segue o rastro de bailarino ou o de dançarino. "Dançarino ou bailarino?" Como essa distinção, que ainda resiste em português, deveria traduzir o dancer de Côté - "I'm not sure that makes me a dancer!’? Quem pode assumir esse papel? Quem pode participar de um legado, de uma memória e também de um regime ou, mais anteriormente, de uma ipseidade de dança? Como se intitula aquele que pode circular livremente e, no sentido radical e perigoso que essa noção pode evocar, nos limites dessa ipseidade? Outra vez estamos falando de democracia por vir.

Mais uma vez, como um giro, retornamos ao direito à filosofia, direito à dança e sua paradoxal khora de sim radical que se dá no acolhimento ao outro. 
Este sim radical não somente faz tremer a objetividade, uma pragmática do sentido de reunião, como também toca, também como tremor, a questão da subjetividade. O sim que poderíamos dizer como resposta a um convite de dança ou a um ser-bailarino-sem-ser que se entrega à dança pode acolher "sem pertencer aquilo a que dá lugar" ${ }^{174}$. É também uma recolocação da questão do quem, como o que ecoa em “quem pode dançar?” e "quem pode fazer filosofia?”, que é também um "quem de direito" com um sentido de "bom exemplo".

O título de bailarino, digno de nome, é assombrado pela genealogia do quem fraternal, como "um quem dá bom exemplo". O rectum de boa conduta, de boa formação vinda da partilha de uma substância ou memória de uma certa ipseidade de dança, passada em segredo dentro de uma certa tradição de herdeiros num fio telemático [outra vez]. O sim radical reservaria outra forma de segredo de acolher "quem quer que seja" ou "o não importa quem", em que se mantém a estrutura do poder guardar, ter em memória, sofrer do mal de arquivo incondicional, mas ao mesmo tempo resistir à ideia reguladora, ao eidos, de quem de direito o porta ou é digno de guardá-lo. "O segredo, não mais do que a democracia ou o segredo da democracia, não deve, aliás, não pode ser confiado como herança a não importa quem" ${ }^{175}$, diz Derrida. Nesse sentido, uma democracia por vir, também na dança, começa por uma desconstrução do "paradoxo do exemplo", do "bem dançar", que é também um "como dançar". Uma questão ético-política dos corpos que podem dançar sem horizonte começa pelo "não importa quem (...) deve também dar o bom exemplo"176; não importa quem deve começar a dançar.

III.

Já há um método em curso. Já se está num texto que se acredita estar, como uma fé para além da intuição ou da ingenuidade do que se acredita. Essa dramaturgia telemática que acompanhamos até aqui já está inscrita na textualidade telecoreográfica que vinha se desenvolvendo. Uma dança pode chegar mesmo

\footnotetext{
${ }^{174}$ DERRIDA, 2009c, p. 36.

${ }^{175}$ Idem, p. 163.

${ }^{176}$ Idem.
} 
sem ser um puro proferimento de performativo feliz austiniano - foi o que tentei responder a Côté.

Refiro-me outra vez à questão da intencionalidade do sujeito digno de ato de fala que ecoa como condição de performativo feliz austiniano (felicidade pensada como eficácia ou efetividade) já mencionada anteriormente. Retomo outra vez a passagem de Austin avançando um pouco mais:

(A.1) Deve existir um procedimento convencionalmente aceito, que apresente um determinado efeito convencional e que inclua o proferimento de certas palavras, por certas pessoas, e em certas circunstâncias; e além disso, que (A.2) as pessoas e circunstâncias particulares, em cada caso, devem ser adequadas ao procedimento específico invocado. (B.1) $\mathrm{O}$ procedimento tem de ser executado, por todos os participantes, de modo correto e (B.2) completo. (r.1) Nos casos em que, como ocorre com frequência, o procedimento visa às pessoas com seus pensamentos e sentimentos, ou visa à instauração de uma conduta correspondente por parte de alguns participantes, então aquele que participa do procedimento e o invoca deve de fato ter tais pensamentos ou sentimentos, e os participantes devem ter a intenção de se conduzirem de maneira adequada, e, além disso, (r.2) devem realmente conduzir-se dessa maneira subsequente. ${ }^{177}$

Para Austin, o "êxito da ação" performativa está condicionado ao cumprimento de "um procedimento convencionalmente aceito", que inclui o "proferimento [a repetição] de certas palavras, por certas pessoas, e em certas circunstâncias" $" 178$. No entanto, num casamento (exemplo comum de evento performativo) se "proferimos a fórmula incorretamente ou se as pessoas não estão em posição de realizar o ato" ${ }^{179}$ não se dirá, porém, se tratar de um performativo nulo.

Dizemos que não foi levado a cabo ou que não foi consumado, em vez de chamá-lo de nulo ou sem efeito. Mas apresso-me a acrescentar que tais distinções não são rígidas e fixas e, mais particularmente, que termos como "pretendido" e "professado" não resistirão a um exame mais rigoroso. (...) sem efeito, aqui, não significa sem consequências, resultados ou efeitos. ${ }^{180}$

\footnotetext{
${ }^{177}$ AUSTIN, 1990, p. 31.

${ }^{178}$ Idem, comentário entre colchete meu .

${ }^{179}$ Ibid, p. 32.

${ }^{180}$ Idem.
} 
Podemos inferir, que performativos infelizes na concepção austiniana são falhas de procedimento que condicionam a efetividade do performativo à estrutura intuitiva do sujeito, da possibilidade do sujeito discernir e responder sobre as intenções de seus atos. Quando digo que há uma chegada de dança que se dá na minha conversa telemática com Côtè sem ser um puro proferimento de performativo feliz austiniano, estou fazendo resistência à noção de evento de dança necessariamente vinculado à intuição de um sujeito. Há uma dança que acontece na nossa conversação como repetição da diferença, como iterabilidade da atopia da dança. Outra vez, uma dança, mais precisamente, um convite à dança (um convite à pensar com a dança, sobretudo), não pode (plenamente) tomar lugar. Ora, mas esse não tem sido o evento de dança convencionalmente reiterado pela discussão desta tese? Outra vez não estamos pensando a dança sem poder dançar?

Essas questões só podem ter efetividade como questões dignas de serem pensadas, por vez, se retornamos à noção de iterabilidade lançada por Derrida, em Assinatura Acontecimento Contexto (1991), desde a brecha impressa pelo próprio performativo de Austin. A chegada do evento telemático de dança com Côtè é somente pensável se já consideramos a força fraca da iterabilidade ou ainda se consideramos a repetição do estiolamento da différance - parasitologia que Austin tenta evitar no seu exemplo de não performativo, citando o caso do proferimento dos "atores no palco" ${ }^{181}$ sem perceber que sua premissa de cumprimento de "um procedimento convencionalmente aceito" acolhe na sua performatividade a estrutura da repetição, da suplementaridade (o procedimento deve incluir o "proferimento de certas palavras, por certas pessoas em certas circunstâncias"). É a noção de iterabilidade de Derrida que nos permitirá pensar a impossibilidade de um performativo se dá presente a si mesmo: ele se instaura demandando repetição, encetando a performatividade da ação pelo acolhimento de gestos, palavras e pessoas - repetição de alteridade. É nesse sentido que afirmo a chegada de uma dança telemática com Côtè, efetivamente, participando de uma certa estrutura de iterabilidade. Repetindo-se como citação, como outro-outro: a dança vem! Mais de uma: danças vêm lançadas à iterabilidade.

Uma questão de método em curso, repito.

${ }^{181}$ Cf. AUSTIN, 1990, p. 36. 
(...) no interior da clausura, só se pode julgar seu estilo em função de oposições recebidas. Dir-se-á que este estilo é empirista e de certa forma se terá razão. A saída é radicalmente empirista. Procede como um pensamento errante sobre a possibilidade do itinerário e do método. Ela se afeta de não saber como de seu futuro e deliberadamente se aventura. (...) Mas aqui o conceito de empirismo destrói-se a si mesmo. Exceder o orbe metafísico é uma tentativa de sair do sulco (orbita), de pensar o todo das oposições conceituais clássicas, particularmente a em que está preso o valor do empirismo: a oposição da filosofia e da não-filosofia, outro nome do empirismo, desta incapacidade de sustentar até o fim da coerência de seu próprio discurso, de produzir-se como verdade no momento em que se abala o valor da verdade, de escapar às contradições internas do ceticismo etc. $O$ pensamento dessa oposição histórica entre filosofia e empirismo não é simplesmente empírico e não se pode assim qualificá-lo sem abuso ou desconhecimento ${ }^{182}$.

O que está em jogo aqui é, novamente, a pergunta, o sim de uma pergunta, e de uma pergunta específica, se sua força performativa está à altura de uma certa linguagem; se ela nos levaria a uma experiência de pensamento estritamente filosófico, a uma sistemática e histórica forma de se produzir pensamento. Uma certa experiência de redução do pensamento, nos limites estritos de uma razão. Caberia aqui pensar, agora, na incondicional produção de violência da forma de linguagem que se restringe aí. Não no sentido de que a linguagem represente um ato declaradamente violento, que venha invocando o tom de violência. Não. Como disse anteriormente, a pergunta de Côté veio sob o tom que pouco parecia injuriar-me quando questionado do porquê de não ir direto a Nietzsche - que poderíamos aqui ecoar como uma pergunta "de que direito Derrida?".

Essa é ainda, como vimos, uma certa herança arquetípica do uso da razão e de sua pedagogia que excede ao domínio do campo de conhecimento restrito à filosofia - não podemos deixar de notar que o episódio em que estamos nos demorando nesta seção toma lugar no Encuentro que cruza muitos campos de saber não restritos à filosofia. Esse arquétipo circula livremente nos mais variados circuitos acadêmicos e também nas mais variadas formas de debate, de espacialidade do público. É sabido por todos que ali se dispõe a participar do jogo da reunião, do espaço de fórum, que perguntas podem e devem (como uma dívida

\footnotetext{
${ }^{182}$ DERRIDA, 1973, p. 198.
} 
de título) ser enunciadas. $\mathrm{O}$ direito de perguntar é um direito à ameaça. Ameaçar a razão de outrem, como questionar os caminhos e escolhas de uma pesquisa, no circuito acadêmico, é de certa maneira esperado e expectado por todos, mas em um tom dentro de certas convenções do limite acadêmico. Ameaça-se a passos de lobo, sem deixar escutar a sua chegada.

Aquele que pergunta não precisa declarar "eu estou te ameaçando". Ou seja, a pergunta "por que não ir direto a Nietzsche?" não representa uma violência direta; não deixa escapar nenhum tom de violência, mas exerce uma violência na medida em que exige ou convoca resposta (mesmo que aquele que a profere não tenha exigido uma resposta). É de outra máquina não direta e consensual de violência: é preciso responder para se manter a circularidade do jogo, e é somente na capacidade de responder que se afirma o sujeito - acadêmico — digno de nome e direito, sujeitado à sua arqui-genealogia-pedagógica. É justamente esse $e ́$ preciso que performatiza a violência vinda da interpelação do outro. Não existe sujeito anterior à interpelação. Há sujeito somente na capacidade de responder ao chamado do outro que vem, podendo, assim, se inserir na ipse de uma linguagem.

Tal ameaça, a passos de lobo, é o que Derrida, em A Besta e o Soberano, nos diz ser própria da analogia entre o modelo de seminário e fábula: "entre seminário e o modo de ficção [na sua dupla atração entre fixação e fissura], simulacro, discurso fictício, a narração 'era uma vez' e 'como se"”183. Esse modo fabuloso de um seminário de fazer conhecer e circular certo uso do conhecimento, em um tom popular de livre circulação e exercício de conhecimento, é o que estou chamando de arqui-genealogia-pedagógica - uso da razão próprio da forma de debate da instituição acadêmica.

Sem poder me demorar muito, outra vez por questão (e medo) de desvio, nessa analogia entre fábula e seminário, trago para a cena o que Derrida chama de porvir-terrorismo do terror, que ecoa no saber-como e no bem saber do fazerconhecimento e ao mesmo tempo corporifica o medo como proteção dentro de um certo regime de soberania - que, como vimos anteriormente, não se limita à teoria do Estado e, com Derrida, pode ser pensada como qualquer força de uma

${ }^{183}$ Derrida, 2009b, p. 24, comentários meus. [Todas as traduções são minhas] 
ipseidade, uma reunião a si ${ }^{184}$. Aceita-se o jogo fabuloso do seminário, submeterse ao exercício de opinião pública em público [talvez fosse mais prudente dizer uso da razão publicamente, para friccionar os limites entre episteme e doxa, que ecoam na distinção entre razão e opinião, distinção decisiva da tradição do debate entre filosofia e não filosofia, como urgência para um mundo das luzes por vir, ou de um pensar sem horizonte, que vimos pensando com Derrida] para exercer os limites da soberania de uma certa noção de conhecimento, de um bem saber, que começa, pedagogicamente, a passos de lobo, com o sentir medo ou pânico. É preciso submeter-se a tal experiência, para não temer o exercício seminal do uso da razão em nome da razão - e a aproximação etimológica entre semen e seminarium nunca foram tão estrategicamente oportunas:

[...] uma essencial e estrutural mola mestra de subjetividade, de subjeção, de ser-sujeito, de submissão ou sujeição política. E aí [nessa fábula seminal] encontraríamos, tão perto quanto a soberania, o medo: medo como ele é definido por Leviatã, por exemplo. Leviatã é o nome de uma máquina-animal designada para causar medo ou de um organon protético de estado, um estado como prótese, o órgão de um estado de prótese, que eu apelido de prostático [prosthstatics], que funciona no medo e reina pelo medo. Por exemplo, no capítulo 27 de Leviatã, medo é definido "como" a "única coisa" (...) que, na humanidade do homem, motiva obediência à lei, não infração da lei, e continuidade das leis. $\mathrm{O}$ correlato ao lado das paixões, o afeto essencial da lei, é o medo. E como não há lei sem soberania, nós teremos que dizer que a soberania chama, pressupõe, provoca medo, como sua condição de possibilidade, mas também seu principal efeito. Soberania [de qualquer espécie e não somente de Estado] causa medo, e o medo faz o soberano $^{185}$.

A soberania chama, pressupõe, provoca medo, nos diz Derrida. Porém, se a soberania é também fruto do exercício de uma condicionalidade humana, a de um ser-soberano - que também sente medo, ainda que não natural (protético à sua natureza de ser imortal) e que, desde Leviatã, é uma construção (como uma máquina) da humanidade obediente às leis, ela (a soberania) é também desconstrutível. A sua divisibilidade no tempo, entregue à história da humanidade,

\footnotetext{
${ }^{184}$ Para acompanhar o desenvolvimento de Derrida sobre a questão entre fábula e terror $c f$. DERRIDA, J. The Beast \& The Sovereign. Chicago: The University of Chicago Press, 2011, notadamente, a "First" e a "Second Session" (pp. 01-62).

${ }^{185}$ DERRIDA, 2011, pp. 68-69. [Comentário meus].
} 
é a brecha de sua desconstrução. A duplicidade do medo da máquina-homem, de sentir e fazer reinar o medo, é a brecha da força fraca de toda soberania. Ao mesmo tempo, besta e soberano precisam sentir medo para que haja lei ${ }^{186}$. No entanto, se essa forma prostática de se exercer uma força, a soberania, como nos diz Derrida, não é domínio somente do Estado, mas também é própria a toda ipseidade, toda forma de autoafirmação, de circularidade de si, abrem-se então um chamado e um convite a se pensar sobre o medo da hybris, do excesso e da desmesura que se exerce em todas as formas de força. Até mesmo da força de uma pergunta, da organização de posições em torno de uma simples pergunta.

O “quem tem medo de...?” se mantém na fabulação entre a formulação de pergunta e o direito de resposta no debate filosófico - e essa prótese também se mantém na ficção de dança encenada por mim e Côté. Uma “simples" pergunta, ainda que como um convite ao debate, ou até mesmo de um debate de certa dança, sem nenhuma ingenuidade, só se faz possível dentro do jogo de atrair e ser perseguido por perguntas. Agora, se esse jogo é convencional, protético, divisível à mortalidade do tempo e, portanto, não natural, ele também é desconstrutítvel. $\mathrm{O}$ descentramento de perguntas, o deslocamento do medo, de quem a quem, ao mesmo tempo, pode transitar no perigoso deslize entre subjeção e sujeição, mas também pode abrir rotas de fugitividade.

\footnotetext{
${ }^{186}$ Hobbes fala da relação de medo e coragem, a "natureza timorata dos homens", e de sua condição - por contrato - ora justa, ora covarde, ora uma traição, no Cap. XXI - Da Liberdade dos Súditos, de Leviatã. É também no mesmo capítulo que o autor falará da questão da obediência como proteção e da mortalidade da soberania (portanto divisível ao tempo, portanto histórica dirá Derrida). Acompanhemos duas passagens de Hobbes suplementares: 1. “(...) embora o seu soberano tenha suficiente direito de o punir com a morte em caso de recusa, pode não obstante em muitos casos recusar, sem praticar injustiça, como quando se faz substituir por um soldado suficiente em seu lugar, caso este em que não está desertando do serviço da república. E deve também admitir o temor natural, não só às mulheres (das quais não se espera o cumprimento de tão perigoso dever), mas também aos homens de coragem feminina. Quando dois exércitos combatem, há sempre os que fogem, de um dos lados, ou de ambos; mas quando não o fazem por traição, e sim por medo, não se considera que o fazem injustamente, mas desonrosamente. Pela mesma razão, evitar o combate não é injustiça, é covardia. Mas aquele que se alista como soldado, ou toma dinheiro público emprestado, perde a desculpa de uma natureza timorata, e fica obrigado não apenas a ir para o combate, mas também a dele não fugir sem licença do seu comandante (HOBBES, 2003, p. 186); 2. "A soberania é a alma da república, e uma vez separada do corpo os membros deixam de receber dela o seu movimento. A finalidade da obediência é a proteção, e seja onde for que um homem a veja, quer na sua própria espada quer na de um outro, a natureza quer que a ela obedeça e se esforce por conservá-Ia. Embora a soberania seja imortal, na intenção daqueles que a criaram, não apenas ela se encontra, por sua própria natureza, sujeita à morte violenta em razão de guerra externa, mas encerra também em si mesma, devido à ignorância e às paixões dos homens, desde a sua própria instituição, grande número de sementes de mortalidade natural, por causa de discórdia interna" (Idem, p. 189).
} 
Não há razão especial alguma para se escolher Derrida nem qualquer outro autor. A razoabilidade, a pertinência de uma tal escolha, do poder decidir sobre a aproximação e a distância de um autor/nome com quem se escreve/pensa junto não se dá de maneira direta - é o que tentei demonstrar, dar exemplo, na fabulosa conversação com Côté. Nesse gesto, escreve-se junto sem jamais pertencer ou reivindicar um domínio de direito à herança, como um "eu sou derridiano" - o que nos autorizaria afirmar tal pressuposição? A noção de afecção teórica como amor que obsidia — It's about love... Derrida haunts myself, disse elipticamente - diz respeito ao vem de um pensamento, de uma perseguição — ora sujeição, ora fugitividade —, de um processo empírico daquele que segue danças no rastro de sua economia singular de roubo, empréstimo, atribuição de valores, dívidas, chamados, direitos de resposta, giros, desvios etc. "É preciso começar de onde quer que estejamos", nos diz Derrida, "e o pensamento do rastro, que não pode não considerar o faro, já nos ensinou que seria impossível justificar absolutamente um ponto de partida. De onde quer que estejamos: já num texto em que acreditamos estar" ${ }^{\text {"187, }}$, e ainda que esse estar que se acredita - a crença que pode ser também uma ficção — não esteja nada aquém nem além do que um seguir na fronteira, como um seguir na fronteira entre dança e filosofia.

Seguir danças com Derrida é uma tomada de posição, não como um partido que se toma parte, porque não se organiza como um partido — porém é preciso dizer que as tomadas de posição em partido, como partidos políticos, assim como as representações de classe e os movimentos sociais, são igualmente importantes de serem exercidas em defesa da própria democracia sempre por vir. Uma tomada de posição de onde se pode partir — seja num movimento de saída ou de chegada, movimento que se segue e pelo qual se é perseguido, movimento da distribuição e também da divisibilidade - ainda que como ficção, ainda que partindo sempre de maneira provisória, demandante do deslocamento entre muitas posições e, portanto, aberta à radical vinda do outro e seu sim. Sim, posição (mais de uma). Sim, posições.

\footnotetext{
${ }^{187}$ DERRIDA, 1973, p. 199.
} 


\section{A Urgência do Fim e as Composições de Nós para Além de Nós}

Partirei para outra rota. A partir dessa seção irei iniciar um pensamento sobre o sentido de reunião e do estar com o outro, sobretudo no espaço público, na experiência social contemporânea pelo viés do tensionamento entre dança e filosofia. Essa discussão já tem sido enunciada entre muitas conjugações nesta escrita do pensar a dança com a filosofia, do pensar a filosofia com a dança, do dizer sim ao pensar, do dizer sim ao sim. Porém agora partirei por outros rumos que ecoam desse pensamento compositivo para forçar-nos a chegada em outras paragens advindas da abertura desse sim-sim.

De onde re-partir? Do método exorbitante que tenho performado até então, só me resta responder: "de onde quer que estejamos: já num texto em que acreditamos estar". Resposta que não assegura nenhum começo, por sinal. Mas tomarei da fé que ecoa em "acreditamos estar" para forjar um re-começo. A fé no nós abrirá uma primeira discussão. Pensar o nós, essa forma de composição singular que na enunciação já captura uma noção de experiência coletiva, um certo modo de existência. Quem diz nós a quem? Questão insólita de escala formidável - diriam alguns, talvez. Mas não pretendo aqui falar de todos (os) nós dessa escalada. Vou partir de um faro singular. Seguirei um rastro por um faro, por uma decisão de mudança de rota pontual para exorbitar a clausura circular em que o pensamento do rastro nos coloca. Mas de que faro estou falando?

Permitam-me citar novamente a passagem de Derrida, em Gramatologia (1973), em que ele nos apresenta um método exorbitante do pensamento da desconstrução:

A abertura da questão, a saída para fora da clausura de uma evidência, o abalamento de um sistema de oposições, todos estes movimentos têm necessariamente a forma do empirismo e da errância. Em todo caso, não podem ser descritos, quanto às normas passadas, senão sob esta forma. Nenhum outro rastro está disponível, e, como estas questões errantes não são começos totalmente absolutos, deixam-se efetivamente alcançar, em toda superfície delas mesmas, por esta descrição 
que também é uma crítica. É preciso começar de onde quer que estejamos e o pensamento do rastro, que não pode considerar o faro, já nos ensinou que seria impossível justificar absolutamente um ponto de partida. De onde quer que estejamos: já num texto em que acreditamos estar ${ }^{188}$.

Os grifos da passagem são de Derrida, "os quais eu também grifaria” comentei já, em rodapé, no final de Marcas Preliminares. Porém quero ainda sacar a questão do faro que aparece lançada aí. "O pensamento do rastro, que não pode considerar o faro", diz Derrida. Se nos demorarmos nessa sentença, num golpe certeiro, diríamos que faro escapa ao pensamento do rastro (à suplementação infinita). Não podemos deixar de notar que o faro já está inserido nessa passagem exorbitante, ou seja, o faro que escapa exorbita o pensamento exorbitante. Nesse sentido, o faro é, talvez, o mais radical dos rastros deixados por Derrida sobre o método exorbitante, pois ele possibilita escapar ao círculo vicioso de rotas já traçadas para abrir caminhos para outras rotas. Acredito que farejar é, então, uma possibilidade de mudança de rota [eu disse acredito como um golpe de fé], e dessa maneira o método exorbitante não se opõe ao faro.

Farejarei, então, a partir do faro sem garantias deixado por Derrida. Partirei de sua fé exorbitante para levar-nos a uma mudança de tom, de rota e de cenário; um giro sem eixo, sem horizonte. Farejarei como na errância de um animal, na sua fé de seguir farejando, desviando de uma rota a outra pelo caminho. Em outras palavras, seguirei um faro para abrir outros sim-sim por vir.

Pelo faro, precisarei, inicialmente, diluir uma certa predominância do pensar com Derrida e das questões mais diretamente ligadas à dança ${ }^{189}$ para forçar um giro com Bruno Latour. Porém esse deslocamento se fará por uma urgência do lançar-se ao princípio do precipício que se atira agora sob o faro de uma questão, “de escala formidável” - eu escrevi acima, como a do nós. Urgência que poderá nos lançar a outras perguntas ético-políticas da desconstrução com a filosofia, com a dança por vir. Mas esse é apenas o começo de um faro. Logo depois e quando depois, notaremos, espero (já sem nenhuma

\footnotetext{
${ }^{188}$ DERRIDA, 1973, p. 199.

${ }^{189}$ Acredito que já pude me demorar tempo suficiente sobre a reflexão da existência, de fato e de direito, de questões diretas da dança, no aí justo de uma dança. Já deixei rastros consideráveis para entendermos que não há discussão direta e de direito da dança. Porém acredito que podemos ainda falar de "questões mais diretamente ligadas à danç̧a" ao menos como uma estratégia pontual e restrita de um dado discurso, para restrição de um certo discurso, ou de um lugar de discurso, como o da estratégia que emprego agora.
} 
garantia além do faro), pelos rastreamentos mais diversos, que a tal diluição a que me referi é artificial, como artifício de uma estratégia de lançamento para outros faros das próximas seções.

Dizendo sim-sim ao faro exorbitante, partirei para uma questão singular sobre o nós. Uma urgência de pensamento de um certo nós que advém inicialmente com Bruno Latour.

Bruno Latour, em uma de suas recentes contribuições, Waiting for Gaia: Composing the common world through arts and politics (2011), e nas conferências Facing Gaia - Six lectures on the political theology of nature (2013), apresenta um projeto para construção de uma cosmopolítica, atravessada por artes, ciência e política, para se pensar ações efetivas que respondam às questões lançadas pelo Antropoceno e a urgência do aquecimento global. É uma proposta muito tentadora que anuncia certo frescor às pesquisas contemporâneas ansiosas, cada vez mais, por gestos transdisciplinares. No entanto, tal projeto, ao menos nesses textos, parece não indicar uma mudança radical nos modos de agenciamento político de um certo nós, ou melhor, na convocação de um nós que suplica e deve responder a uma responsabilidade coletiva, ou moral política, evocada pela pergunta “o que devemos fazer?”. Questionando a pergunta, aponto neste capítulo como a articulação desse sujeito, nós, e seu suplício de responsabilidade, “o que devemos fazer?", pode replicar, mais uma vez, os esquemas políticos de soberania frente ao outro. Minha suspeita é que tal jogo entre "soberania e outro" é ainda mais seriamente endossado quando a articulação entre política e artes recai no velho esquema de instrumentalização e empoderamento pela experiência estética agora munido de um argumento ainda mais sofisticado, ou até mesmo mais autoritário, de razão científica e sobrevivência da espécie - outra vez o nós. Meu desafio aqui é, portanto, pensar brechas sobre as composições de espacialidades entre arte, política e filosofia, atento a essa “outra vez moral”. Não pretendo aqui fazer uma profunda análise do pensamento de Latour, mas, sim, insistir na pergunta, como um problema, "o que devemos fazer?”, oportunizada por Latour e já num lançamento para além dele, faro que nos levará a outros faros. 
Iremos acompanhar o argumento de Latour passo-a-passo.

A pergunta "o que devemos fazer?" sempre invoca uma metafísica e uma ética contingente. Na sua performatividade, ela nos coloca sob um nós em torno de uma direção de sentido para a qual devemos agora rumar para estar aí, para fazer sentido estar aí e também, mais precisamente, estar/ser aqui agora. Convoca um nós para pensar-agir. Em diferentes discursos, a retomada do que e do quem determina o modo como existimos e o modo como respondemos a nossa existência; o que somos e como agi(r)mos diante de, pondo à prova a capacidade do sujeito, do esclarecimento de um certo sujeito, em lidar com a urgência de uma incondicional temporalidade que o atravessa: "e agora, o que devemos fazer?".

É com essa mesma pergunta que Bruno Latour inicia seu texto Waiting For Gaia: Composing the common world through arts and politics $(2011)^{190}$, e arriscaria ainda dizer que ela retorna como um espectro em outros textos e palestras recentes do autor ${ }^{191}$ : "o que devemos fazer quando confrontados com uma crise ecológica que não se assemelha a nenhuma das crises de guerra e de economia - cuja escala é formidável, com certeza, mas com a qual estamos habituados, uma vez que ela é humana, demasiadamente humana?"192. E, ainda: “o que fazer quando as perguntas são muito grandes para todos, e especialmente quando elas são muito grandes para o escritor, isto é, para mim?"193. Com essas duas perguntas, Latour enceta um problema que parece pertencer a todos nós, o que remodela o que chamamos de nós, muito maior que qualquer autorreferência capaz de responder por um eu e ter uma assinatura. Maior do que todo aquele que pode escrever eu e assim dar sentido a perguntas como "o que fazer ele, eu,

\footnotetext{
${ }^{190}$ Palestra conferida no Instituto Francês de Londres, em novembro de 2011, na ocasião do lançamento do programa Science Po, dirigido por Bruno Latour. Para este trabalho, além do texto original em inglês, usei também como referência a livre tradução da colega de doutorado Alyne Costa (PUC-Rio), a quem desde já agradeço as contribuições. As traduções que aqui seguem são minhas, mas sempre acompanhadas pelas contribuições de Costa, algumas vezes citadas em nota de rodapé.

${ }^{191}$ Refiro-me, sobretudo, ao conjunto de conferências realizadas em Gifford - EUA, em fevereiro de 2013, disponível em vídeo e também numa transcrição não formal - ainda não publicada oficialmente - , presente no site do autor, referente à urgência da crise climática, v. $<$ http://www bruno-latour.fr/>. Todas as traduções são minhas.

${ }^{192}$ LATOUR, 2011, p.1.

${ }^{193}$ Idem, p. 2.
} 
você?" - esses todos sujeitos capazes de ler/escrever um texto e atribuir algum sentido para isso como quem estabelece alguma dívida, algum retorno possível, uma herança, um chamado nós: o que fazer?

Esse problema que parece ser arrastado por Latour já se coloca como uma desconexão e uma incondicional contingência, ao mesmo tempo nos tornando impotentes e nos exigindo uma urgência entre a responsabilidade e a ação. Porém a urgência para a qual Latour chama atenção não diz respeito ao poder me afastar para um lugar privilegiado que me permita olhá-la globalmente no todo que se coloca diante de mim. Trata-se de um chamado à reflexão sobre aquilo que chamamos de "lugar" como "morada" e que pode deixar de existir, nos conduzindo à radical possibilidade de não ser e de não haver mais o Ser. Essa questão é de escala tão desproporcional que se corre o risco de nada podermos fazer, por não haver nenhum quem ou que a que recorrer nem outro lugar para onde escapar.

Esse parece ser o fim sem fim anunciado pela crise do aquecimento global que, não somente Latour, mas também uma rede muito grande de pesquisadores da ciência ${ }^{194}$ - James Lovelock, Isabelle Stengers, Clive Hamilton, para citar alguns aos quais tive acesso - diz ser impossível reverter. O aumento da temperatura do planeta Terra e a incapacidade dos instrumentos científicos de apontarem um só responsável e uma solução viável colocam todos nós para além de qualquer equação possível entre sujeito e objeto.

Para Latour (2011), a estranheza dessa questão é endossada pelo fato de essa experiência abissal - entre o que somos capazes/incapazes de produzir frente a grandes questões da ecologia - não se assemelhar em nada aos discursos sobre a natureza, com o sentimento de sublime, pelo menos desde o século XIX cantados e contados pelos mais diversos dispositivos retóricos, os quais colocam o sujeito muito pequeno diante da natureza. O sublime - aquela experiência de estranheza do belo kantiano que nos torna pequenos ao transbordamento e ultrapassamento da forma e que ao mesmo tempo re-embaralha as faculdades de juízo - para Latour só pode existir quando a natureza se faz infinita.

No sentido de sublime apresentado por Latour, é da natureza da natureza ser infinita e de uma temporalidade eternamente durável - como as cachoeiras

\footnotetext{
${ }^{194}$ Que compõe o campo chamado de science studies.
} 
que jorram para sempre, nos poemas de Shelley ${ }^{195}$ - que nenhum sujeito é capaz de apreender. Porém, a partir do momento em que a natureza, que tradicionalmente era tratada como um fundo infinito, passa a ter uma iminente urgência de fim - e de um fim por que somos em parte responsáveis, mesmo não tendo decidido sobre isso - , para Latour, há um abismo, não mais o sublime. O problema da aceleração do aquecimento global e a sua demandante geo-histórica, que vem sendo chamada por uma comunidade de cientistas e pesquisadores de Antropoceno, provoca outro tipo de desconexão na medida em que todos nós saltamos para outra experiência do sentido de estar com.

O Antropoceno está sendo considerado por esse grupo de pesquisadores dos science studies como uma época geológica potencial, ou seja, no mesmo nível hierárquico que as épocas do Pleistoceno e Holoceno. Há ainda uma discussão muito acirrada quanto à demarcação política e histórica do período: se desde a agricultura ou a partir da Revolução Industrial ou, ainda, da era nuclear. Mas, em suma, o que essa nova estratificação global de efeito diretamente ético-político enceta é que o humano deixou de ser um mero habitante da geosfera para ser uma de suas forças compositivas, consideradas não mais em proporções de humano a humano, mas, sim, comparáveis a geoforças, tais como as placas tectônicas.

\begin{abstract}
Em seu magnífico livro Comer o Sol, Oliver Morton apresenta uma escala de energia interessante. Nossa civilização global é alimentada por cerca de treze terawatts (TW), enquanto o fluxo de energia a partir do centro da Terra é de cerca de quarenta TW. Sim, nós agora nos comparamos com as placas tectônicas. Claro que esta energia despendida não é nada se comparada aos $170.000 \mathrm{TW}$ que recebemos do sol, mas é muita coisa quando confrontada à produção primária de toda a biosfera (130 TW). Se todos os seres humanos consumissem energia no nível dos norte-americanos, teríamos de operar a $100 \mathrm{TW}$, isto é, o dobro da energia das placas tectônicas. Isso é uma façanha e tanto. "É um avião? É a natureza? Não, é o Superman!” Nós nos tornamos Superman, sem nem perceber que dentro da cabine telefônica não mudamos apenas roupas, mas crescemos enormemente! Podemos ter orgulho disso? Bem, nem tanto, e esse é o problema. ${ }^{196}$
\end{abstract}

\footnotetext{
195 "In the wild woods, among the mountains lone,/ Where waterfalls around it leap forever,/ Where woods and winds contend, and a vast river/ Over its rocks ceaselessly bursts and raves" $e$ depois "The everlasting universe of things/ Flows through the mind, and rolls its rapid waves,/ Now dark--now glittering--now, reflecting gloom--/ Now lending splendor, where from secret springs/ The source of human thought its tribute brings" (SHELLEY apud LATOUR, 2011, p. 2).

${ }^{196}$ LATOUR, 2011, p. 3.
} 
Essa passagem de Latour talvez nos aponte a princípio duas coisas sobre o Antropoceno: a primeira diz respeito ao que já apresentei como a impossibilidade de sentimento do sublime, uma vez que somos colocados como tão poderosos sobre qualquer possibilidade de estar diante de: - nós já sofisticamos muito as nossas tecnologias, e elas agora são mais fortes do que qualquer um de nós, ou seja, já não agem como objetos de nossa responsabilidade intuitiva ${ }^{197}$; e a segunda se refere às desmedidas do progressismo, o fato de nem todas as nações terem o mesmo poder técnico-científico dos EUA, o que contribui, talvez, para que a situação atual do clima não seja ainda pior. Realmente, se tomarmos esses dados como uma nova arquitetura de distribuição e composição do espaço, o Antropoceno pode fomentar outro sentido das noções de coletividade e política, e, talvez, a mais significativa delas seja o fato de que, mesmo não se tratando de uma atmosfera homogênea, o estar com pode produzir forças irreversíveis.

O Antropoceno nos diz que nem eu, você ou qualquer um de nós somos responsáveis isoladamente, da mesma maneira que nem mesmo o ator humano coletivo pode ser responsabilizado "pela façanha". Esgota-se aí a retomada do sujeito, os actantes como sujeitos de suas ações, uma vez que não pode ser "pensado, dimensionado ou medido".

Você nunca encontra ele ou ela. Não é nem mesmo a raça humana tomada in toto, uma vez que os "autores" são apenas uma parte da raça humana, os ricos e os abastados, um grupo que não tem forma definida, limite e, sem dúvida, nenhuma representação política. Como poderíamos ser "nós" que fizemos "tudo isso", já que não há nenhuma política, nenhuma moral, nenhum pensamento, nenhum corpo sensível capaz de dizer "nós" - e ninguém para dizer com orgulho "the buck stops here" ?"198

O poder de decidir já não se dá quando pensamos em escalas tão amplas de reciprocidade do estar com-pondo uma arquitetura de proporções geosféricas e

\footnotetext{
${ }^{197}$ Lembremos aqui o acidente nuclear causado pelo tsunami que assolou o Japão em $2011 \mathrm{e}$ atingiu a usina nuclear de Fukushima. Ninguém precisou apertar um botão para se responsabilizar pelas consequências dos vazamentos de energia nuclear. Também, poderíamos relacionar com o crime ambiental ocorrido nas cidades de Bento Rodrigues e Mariana, em 2014, que matou a vida marina de vários rios e se alastrou por diversas cidades brasileiras. Em ambos os casos, a questão da responsabilidade ultrapassa a decisão intuitiva de um sujeito.

${ }^{198}$ LATOUR, 2011, p. 4.
} 
não autocentráveis. $\mathrm{Na}$ medida em que não há um regulador claro ou precisamente clarificável (ou seja, capaz de ser medido, esclarecido, visualizado), já não se pode atribuir uma reinvocação da noção de política do sujeito, uma vez que o sujeito passou a ser mais um dispositivo, mais uma agência que constitui esse espaçamento chamado Antropoceno - que me parece não ser um lugar nem mesmo uma demarcação meramente histórica, mas uma demanda de outra responsabilidade, ou ainda uma responsividade. Demorar-se na questão do Antropoceno exige um pensamento para além das categorias políticas do sujeito, como empoderamento pelo esclarecimento e tomada de decisão/consciência pela emancipação.

Tal responsividade aponta outra ética-política anterior à capacidade de nos colocarmos diante de ou convocar um nós - evocar um "quem é esse nós?" - para confrontar a pergunta: o que fazer? Se há uma radicalidade ético-política com a chegada do Antropoceno, me parece que ela abala as categorias de representatividade, soberania, força, Estado (e todo telos) que delimitam a ação do humano como um certo "todos nós" sobre um dado solo que nos direciona para um futuro.

Reconheço que a importante contribuição do pensamento de Latour entremeada a muitas discussões a respeito do Antropoceno e do aquecimento global - provoca deslocamentos políticos na contemporaneidade na medida em que nos faz pensar numa certa urgência que ecoa com o assombro do fim (essa palavra indecidível que ao mesmo tempo pode soar como acabamento, fundo e como um remate, uma tomada de sentido). Nessa temporalidade assombrada pelo fim, o que chamamos de terra, solo, habitação, casa, mãe como casa não é um lugar para onde podemos nos dirigir sempre e contar com/sobre suas maravilhas. Não há paz estabelecida na im-permanência do fim. A regulação do telos - a tomada de sentido, a dívida - se pulveriza quando o fim torna-se um espectro impermanente que compõe nossa condição de aterramento.

Acredito que essa espectralidade radicaliza a impossibilidade de comunhão, de sentido e de indivíduos sob um comum harmônico, não por uma incompetência de nossa atual condição, mas, sim, porque ela nos diz que nunca houve uma harmonia como um fundo o qual agora pudéssemos retomar como bandeira. Mais diretamente: se no Antropoceno todos - como qualquer um estão em background - não como um infinito habitável, mas como um fim, um 
fim sem telos, sem governo, embora com suas governanças sem as quais nenhuma ação, gesto, dívida, responsabilidade pode ser programada - nenhum direcionamento metafísico torna-se capaz de reunir a todos, a não ser que permaneçamos nas composições da fraternidade política e todas as suas implicações homogeneizantes.

Porém Latour, ao demorar-se no "que fazer?", aponta uma saída para aquilo que ele chama de ilusão da desconexão através do esclarecimento. Primeiro ele nos diz: "as coisas não estão ordenados por tamanho, como se fossem caixas dentro de caixas. Ao contrário, elas são ordenadas por conectividades, como se fossem nós ligados a outros nós" ${ }^{199}$. Tal conectividade salientaria um processo de "tecelagem-de-tapeçaria de calibração, modelagem e reinterpretação" que mostra que:

(...) mesmo para os cientistas do clima, não existe maneira de medir diretamente a Terra... não temos, de um lado, os cientistas se beneficiando por uma visão completa global e, de outro lado, o pobre cidadão comum com uma visão "limitada local". Há apenas visões locais. No entanto, alguns de nós olhamos para modelos de escala conectados em dados que têm sido reformados pelos mais e mais poderosos programas organizados pelas mais e mais respeitadas instituições ${ }^{200}$.

Com esse argumento, Latour traça a questão da localidade não como um lugar onde as coisas acontecem, mas, sim, como a composição dos acontecimentos sempre como locais. Ou seja, há uma distribuição de conectividades e redes de feedbacks que remodelam ininterruptamente os relevos de composição - que poderia chamar aqui de geocomposições - , tornando qualquer micro ou macro-umwelt - e também todo self e autorretorno temporal e contingente à rede de acessos desses nós ${ }^{201}$, portanto, sempre local. Até aí, tudo bem. O problema é quando o argumento latouriano parece dar pouca atenção à questão da alteridade, de uma política que leve em conta a alteridade. Talvez seja a sua fiança no duplo "mais" - "more and more powerful programs

\footnotetext{
${ }^{199}$ LATOUR, 2011, p. 6.

${ }^{200}$ Idem.

${ }^{201}$ Me refiro aos nodes - em inglês - citados por Latour, que, na tradução para o português, sugere uma ambivalência babélica interessante com o pronome nós, que reúne eu, você e todos como um todo. Retomarei adiante essa babelidade entre nós pronome e nós substantivo.
} 
run through more and more respected institutions" - que apela para um certo ar de soberania da ciência.

Claro que "more and more" é uma resposta para lidar com os assombros causados pelo Antropoceno próximos aos circuitos técnico-científicos. A urgência de ter que responder à altura a tais circuitos técnico-científicos traz em Latour um tom de soberania agora tão poderosa quanto aqueles que estão colocados do outro lado. No entanto, uma questão que me assombra aqui talvez seja: será que essa resposta mais e mais rigorosa modifica politicamente as geocomposições para além da ciência? Quais são os limites dessas geocomposições? Acompanhemos o gesto de Latour.

Em Waiting for Gaia - e também nas conferências em Gifford -, o chamado inimigo está muito claro: o fim da espécie, que provoca uma finitude do natural - anúncio que para a ciência, preocupada ou não com a causa ecologista, é realmente desesperador. O aquecimento global e as estratégias dos climatólogos trouxeram o que habitualmente chamávamos de fundo para frente, transformando o universal em local, mas um local que diz respeito a todos nós e à impossibilidade de haver um nós futuro. Há aí uma mudança, sobretudo, porque esse todo não é identificável. Aquilo que habitualmente se chamava de fundo tornou-se confuso demais com o Antropoceno. Nesse sentido,

(...) é inútil para o ativista motivado ecologicamente tentar rechaçar [shaming] o cidadão comum por não pensar globalmente o suficiente, por não ter um sentimento pela terra como tal. Ninguém vê a terra globalmente, e ninguém vê o sistema ecológico de nenhum lugar [nowhere], o cientista não mais que o cidadão, o agricultor ou o ecologista - ou, não esqueçamos, a minhoca. A natureza não é mais uma coisa abraçada a partir de um ponto de vista distante onde o observador poderia idealmente pular para ver as coisas "como um todo", mas uma assemblage de entidades contraditórias que tem que ser composta junto. ${ }^{202}$

O apelo ao local nessa passagem tem a ver com o estar situado e como esse sítio-in se constitui de um complexo processo de estar-com-pondo entre entidades contraditórias que, por sua vez, compõe outro nós - em sua ambivalência. A meu ver, tomar isso como premissa não define, ou não deveria

\footnotetext{
${ }^{202}$ LATOUR, 2011, p. 6-7.
} 
definir, nenhum lugar de partida, mas talvez um leitmotiv de localidade/situacional.

A proposta de Latour segue então em direção para “o que fazer”, como pensar uma política que responda à urgência do inimigo que pode assombrar o circuito científico e a todos nós: o fim. Em um primeiro momento, sua estratégia se apresenta como um desvelamento das controvérsias que compõem qualquer afirmativa científica. Essa foi a mesma estratégia de que os climatologistas se muniram para responder aos negacionistas ${ }^{203}$, que tomam as controvérsias das composições daqueles para recusar qualquer necessidade de urgência quanto ao aquecimento global, ou melhor, que desconsideram a possibilidade de haver um aquecimento global. Para esses negacionistas - os inimigos ${ }^{204}$ dos climatologistas - a equação se resolve assim (diriam eles): “o processo de tecelagem dá margem a tantas controvérsias que não temos por que nos preocupar com isso". Em contrapartida, a resposta dos climatologistas se dá no mapeamento de controvérsias científicas que permitem construir cosmogramas complexos e emaranhados. Esses cosmogramas são muito distantes das fórmulas reduzidas apresentadas ao grande público pela ciência - o que, no entanto, não impede a construção de uma certa epistemologia. Nesse sentido, há um eco muito significativo sobre a comparação de cosmogramas: "ora, não é porque há controvérsias que não tenhamos que pensar como melhor responder a essa urgência"; e, ainda: "não é porque há controvérsias que podemos dizer que o aquecimento global não acontece".

A verdade científica estaria desde sempre enredada, como toda noção de verdade tal como apontada em Nietzsche, em Verdade e Mentira no Sentido Extra-moral (2002):

\footnotetext{
${ }^{203}$ Termo extremamente complicado, e irei demonstrar o porquê disso em algumas linhas aqui e no comentário a seguir. A colega Alyne Costa, em nota de rodapé de sua livre tradução, apresenta de maneira muito precisa ecos do termo negacionista: "A expressão 'negacionista' originalmente se referia às pessoas que negam que o Holocausto tenha acontecido. Na discussão ecológica, o termo foi apropriado para se referir àqueles que negam as mudanças do clima". Identifico nesse termo uma possível estratégia retórica de apelo moral, que mais uma vez retorna em Latour.

${ }^{204}$ A dúvida é: qual dos dois lados compôs tal linha divisória? Se primeiro os climatologistas, ao chamarem os outros - o inimigo - de negacionistas, demarcando, assim, aqueles que colocam suas práticas em dúvida e, por tabela, o aquecimento global, apelando para uma memória e também uma dívida moral civilizatória; ou os chamados negacionistas - e esse ser chamado é ser chamado pelo outro - , que veem seus processos técnico-científicos e sua supremacia ameaçados pela profecia do fim e pela culpa a qual são julgados carregar. Mais adiante, retornarei a essa questão de demarcação de inimigo e de como ela mantém o mesmo código tradicional de pensamento político pela herança fraternal.
} 
O que é, portanto, a verdade? Uma multidão móvel de metáforas, de metonímias, de antropomorfismos, em resumo, uma soma de relações humanas que foram poeticamente e retoricamente alçadas, transpostas, ornadas, e que, depois de um longo uso, parecem a um povo firmes, canônicas e constrangedoras: as verdades são ilusões que nós esquecemos que o são, metáforas que foram usadas e que perderam sua força sensível, peças de moedas que perderam seu cunho e que são consideradas a partir de então não já como peças de moeda mas como metal $^{205}$.

O gesto de desvelar as multidões de controvérsias, tal como a metaforicidade nietzschiana, não tem nada a ver com o relativismo - ou com a máxima "tudo é interpretação". Ao contrário, ele é não relativista na medida em que o relativismo necessita de um mesmo ponto fixo - um objeto claramente definível - sobre o qual podemos multiplicar as infinitas visões. A metaforicidade apelada por Nietzsche nos diz que não há a verdade mesma, essa também é uma composição, enredada num processo violento de apropriação/subjetivação. Nesse sentido, caçar, mapear, construir uma genealogia e enredar tais controvérsias é um jogo aberto pela metaforicidade não como um modo de representação do real, mas como uma escritura sem a qual não há como nos referirmos a nada, nem mesmo sobre o que se diz "real" ou a distinção que se faz entre real e imaginário.

Talvez, um grande mérito dos climatólogos foi aplicar tal martelada nos processos de metaforicidade sobre aquilo que comumente era chamado de Terra, sobre o que comumente era reduzido a ser um objeto, passível de verificações e cálculos; um objeto distante e necessariamente isolado de nós. Nessa martelada, não se conjuga mais a necessidade de se restituir uma realidade, mas, sim, pensar como queremos construir tal realidade. Há aí outra responsividade que não apela para nenhuma moral reguladora.

O jogo de comparações entre cosmogramas pode nos dizer que, se há confusão, há desde sempre, eis uma potência da política mesma. Porém Latour se vale dessa estratégia para explorar os vínculos entre aliados e inimigos, rascunhando um sentido particular da cosmopolítica:

Como é interessante ver as conexões entre grandes empresas de petróleo, fabricantes de cigarros, antiaborcionistas,

\footnotetext{
${ }^{205}$ NIETZSCHE, 2002, pp. 181-182.
} 
criacionistas, republicanos e uma visão de mundo que contempla muito poucos humanos e muito poucas entidades naturais. Isso é o que a política se tornou. Vamos confrontar os mundos uns contra os outros, uma vez que se trata de uma guerra de mundos. ${ }^{206}$

A guerra de mundos não está para acontecer com a chegada de um apocalipse messianicamente esperado. Ao contrário, há uma guerra de mundos que perfaz a constituição do agora e os modos de interpretação de qualquer cosmograma, e essa arquitetura é uma agência de guerra sem reino e sem um controle para o qual possamos nos dirigir e armar planos estratégicos de combate direto.

Para Latour, o jogo de cosmogramas, ao passo que desvela os modos de operação da ciência, se torna um dispositivo para compor aliados e inimigos: “com essa lição na mão, começamos a imaginar como fazer o mesmo procedimento em nossos esforços para reunir um corpo político capaz de reivindicar sua parte de responsabilidade pelo estado de mudança da Terra" ${ }^{207}$. Ou a lição dos cosmogramas, em nossas mãos, estabelece quem somos: um certo nós e um certo eles, corpos que só podem ser bem formados se convencidos de uma moral $^{208}$. Pois, sim, estou convencido de que a responsabilidade pensada por Latour é regida pela moral.

Nesse sentido, para problematizar o corpo político pensado por Latour, sugiro que o Antropoceno seja aqui tomado como uma mesa de trabalho - tal como a noção de hipótese é tomada por Derrida em Enlouquecer o Subjétil (1998) - que nos lança para além da responsabilidade de dar um direcionamento a nossas ações, oferecido por um que ou um quem capaz de equacionar tal solução, mesmo que esse quem seja um quem coletivo.

Para Derrida, "a hipótese é também um subjétil, e o subjétil, uma hipótese de trabalho, como se diria uma mesa de trabalho" (1998, p. 96). O

\footnotetext{
${ }^{206}$ LATOUR, 2011, pp. 7-8.

${ }^{207}$ Ibid., p. 8.

${ }^{208}$ É preciso refletir radicalmente sobre esse corpo político bem formado, formado para o bem regido por uma moral - e a não verdade do corpo, o corpo subjétil, presumido no atravessamento entre Derrida e Artaud. Em outro lugar [cf. ANDRADE, 2013a; 2013b], pensei algo sobre os problemas dessa noção de corpo bem formado, que Artaud entendia como patologia do homem, sobre o ter que ter um corpo e esse corpo ter que ter um eu, um bem, portar um nome e, assim, constituir uma gênese que não lhe deixa escapar de deus, de ter que ter um deus. A partir de agora quando me referir ao problema do corpo bem formado estou me referindo a esse pensamento de Artaud.
} 
subjétil, por sua vez - palavra que se deixa deslizar entre sub (o que jaz, o fundo, fim) e il (o lançado, ele, o porvir), entre o ser-fundante e o ser-fundado, perturbação trazida pelo atravessamento Derrida/Artaud - acontece anterior ao que e ao quem. Ele performatiza toda possibilidade de queixar-se da traição, de uma negativa, que pode escapar e jamais chegar aos olhos, a possibilidade de tornar-se visível/calculável, completamente. É a espera que mesmo sem o chegar já perturba, sem ter que ser "um ser, nem um sujeito, nem um objeto".

O subjétil, nas palavras de Derrida, seria:

Em suma, tudo e qualquer coisa, de modo que não há mais sentido, principalmente loucura a perguntar "quem é?". Pode-se até perguntar, perguntar-se "o que é"? "É que?" Não, não é nada, nada que seja, nenhum ser determinado, já que isso pode assumir a figura determinada do que quer que seja. Transcendência do Outro - e do Um. Para além do ser, epekeina tes ousias: "Eu sou um e não numeroso", diz Artaud, mas também o subjétil. Eis em que ele exaspera, e ela também, eis em que o que se chama de subjétil começa a invocar os gestos, e a gestação e a gesticulação mais contraditórias. ${ }^{209}$

É preciso ainda lembrar que a palavra subjétil é também um antigo jargão da pintura que se refere ao mesmo tempo ao que estava embaixo como suporte ou substância (subjectum) e em cima como superfície, matéria da pintura ou escultura. Nesse sentido, seria todo entre que escapa tanto da forma quanto do sentido e da representação. Derrida, ao aproximar o sentido de hipótese ao sentido de subjétil, como mesa de trabalho, abre uma brecha para se pensar a hipótese como uma superfície que não é nada em si, um fundo sem fundo que pode ser tomado ao mesmo tempo como suporte e lançamento. Então, primeiramente, quando digo que o Antropoceno poderia ${ }^{210}$ ser um subjétil, como uma hipótese, quero então afirmar que, antes mesmo de ser aceito, ou melhor, ser dado por uma comunidade científica, pode, sim e talvez (na temporalidade de uma hipótese: um sim-talvez necessário à sua clareira), evocar uma responsividade. Em seguida, afirmo que haveria aí uma ambivalência entre a dação e o porvir de toda hipótese como subjétil [esse suporte-louco/suporte-fora-de-si que invoca "gestos, gestações e gesticulações contraditórias"]; ou seja, podemos até chamar - no sentido de

${ }^{209}$ DERRIDA, 1998, p. 110.

${ }^{210}$ Lanço o que poderia ou deveria ser o devir do tempo de qualquer hipótese, de ser só mais uma hipótese e, portanto, jamais a única hipótese, como uma só hipótese, como a hipótese de um há ainda "uma só saída", "um só deus". 
evocar - uma hipótese, o Antropoceno como hipótese (mesmo que seja dada como tese pelos estratigrafistas), mas como subjétil, e ele mesmo como hipótese, como uma khora ${ }^{211}$ - o Antropoceno - poderia escapar, nunca chegar completamente. Ainda, como elipticamente aponta Derrida, “a palavra subjétil pode ter história, mas ela mesma é antes um subjétil”, e aí diria que toda hipótese pode ter uma história, pode-se dar a ela uma história e constituir torres, retornos, circunlocuções etc., mas, antes, a hipótese mesma é uma composição. É preciso um esforço de uma hipótese abissal para seguir pensando o Antropoceno. [Eu disse uma, mas também diria mais de uma e ainda basta de uma por razões que espero pensar melhor mais adiante. $\left.{ }^{212}\right]$

Nesse sentido, diferentemente do que Latour (2011) parece querer responder, torna-se impossível construir um novo rumo para a pergunta "o que fazer diante de?" - e agora aquele que está diante de é o Antropoceno - porque o Antropoceno mesmo, como hipótese, pode também não dizer respeito ao colocar-se diante de. Não há sujeito diante do Antropoceno, na medida em que o sujeito se tornou somente mais um anthropos - para seguir uma proposição latouriana $^{213}$. O Antropoceno não pode ser colocado como objeto, e nós não nos

\footnotetext{
${ }^{211}$ Pensemos essa comparação acompanhados do pensamento de Derrida sobre o subjétil de Artaud: "Lugar, separação e receptáculo, diferença, intervalo, interstício, espaçamento como a khora: nem sensível nem inteligível, nem a cópia mimética do paradigma do eidos, nem o próprio paradigma ou o próprio modelo, antes um 'terceiro genos', difícil de conceber de qualquer outro modo a não ser por um 'raciocínio bastardo' híbrido, como que 'num sonho', diz Platão no Timeu, num sonho mas além de toda sensação. Essa anestesia não significa que a khora seja inteligível. Ela se mantém, como subjétil, embaixo, e é assim que ela merece seu nome de receptáculo: hypodokhé. E se compara esse receptáculo a uma ama de leite: 'Qual propriedade (dynamin) devese supor (hypolepteon) que ela tem por natureza (kata physin)? Antes de tudo alguma deste gênero: de todo nascimento (pases geneosôs) ela é o receptáculo e como que (oion) a ama' (49a). Como que a ama: somente uma comparação, uma figura" (DERRIDA, 1998, pp. 110-111, grifos do autor).

${ }^{212}$ Notadamente na sexta seção desta tese. Os leitores mais ansiosos, afetados de uma urgência abissal e de uma resposta mais imediata ao mar que se abriu na khora do subjétil, poderão escolher saltar para essa outra seção por vir já e, quando depois, retornar às paragens que ficaram pelo caminho.

${ }^{213}$ Latour, na conferência 4 de Gifford - Playing on the stage of the New Globe Theatre -, lembra que o anthropos não se encerra no humano, mas seria um outro corpo formado por todos os actantes que participam do processo de tecelagem da geosfera. Nesse sentido, não se trata de antropomorfizar os actantes - dando-lhes características humanoides - , eis que não há como garantir uma intencionalidade reguladora entre eles. Adverte: "vou usar a palavra 'anthropos' para designar o que não é mais o 'humano-por-natureza' nem o 'humano-fora-da-natureza', mas algo mais inteiramente, um outro animal, outra besta ou, mais educadamente, um novo corpo político ainda a emergir. Tal é o tema principal desta série de palestras: definir a escala, escape, escopo e objetivo dessas pessoas novas tomadas solidariamente que involuntariamente se tornam os novos agentes da geo-história. Uma coisa é certa: esse ator fazendo sua estreia no palco do presente New Globe Theatre nunca atuou num papel de trama tão densamente enigmática" (LATOUR, 2013, p. 79, Tradução minha).
} 
tornamos objetos de acolhimento de sua ação, pois não há como pensar nem atribuir-lhe uma intencionalidade. Isso não significa paralisação nem negação dos efeitos advindos de sua chegada como hipótese, os gestos, as gesticulações e as gestações advindos do trabalho sobre essa hipótese Antropoceno, como a questão do aquecimento global. Ao contrário, pensar essa outra hipótese abismalmente contraditória pode dar uma resposta de adiamento à noção de contingência puramente histórica ou genética - esta última, conforme formulada por Richard Dawkins (1979), que é fadada a uma cultura do gene egoísta.

Nesse sentido, a resposta moral dada pelo demorar-se de Latour sobre a pergunta “o que devemos fazer?", me parece, recai numa repetição de um mesmo esquema a que ele diz querer se contrapor, na medida em que o Antropoceno evoca [ou deveria radicalmente evocar] outro aterramento [ou outra navegação diria, já virtualizando um quando depois da chegada das águas por vir] apelador de outra temporalidade que extrapola qualquer tomada de consciência coletiva sobre a ação de um nós, seja nós que cremos no Antropoceno ou nós que queremos negá-lo. Sim, acredito que o Antropoceno pode nos lançar para outro espaçamento de composição que, também, pode desdobrar outra responsividade ético-política. É exatamente sobre a insistência dessa outra responsividade, uma responsividade lançada ao outro, lançada ao trabalho sempre por vir, que não deveríamos - se quisermos mesmo pensar em um desvio radical de um pensamento político - retornar ao resgate da moral sempre evocado por Latour como um certo sentimento de culpa ou superação da culpa: “como agirmos se não temos moral para lidar com essa questão?". Ou ainda quando diz:

O que significa ser moralmente responsável na época do Antropoceno, quando a Terra é moldada por nós, pela nossa falta de moralidade - pior ainda, quando não há um "nós" identificável para arcar com o peso de tal responsabilidade - e quando até a conexão entre nossa ação coletiva e sua consequência é posta em dúvida? ${ }^{214}$

Efetivamente, não há uma moral. É preciso que não haja $a$ moral $^{215}$. Agora me intriga pensar por que Latour $(2011 ; 2013)$ parece querer reinstaurar um discurso da moral como uma redenção para apontar nela uma solução para o

\footnotetext{
214 LATOUR, 2011, p. 4.

${ }^{215}$ Discutiremos com Butler (2015), no final da quinta seção, as implicações de violência ética que ecoam desse sentido de moral como "a" moral.
} 
problema. Seria, mesmo, o Antropoceno uma questão de moral? Quais implicações estão sendo negligenciadas quando reivindicamos o sentido de moral, especialmente essa moral redentora à política? Me parece que tal moral na política é ainda uma evocação de um telos, que, como um deus, governa a distância. A responsabilidade esclarecida teleológica, que ganha vestes de moral no discurso de Latour, corre um risco de recair como uma agenda, um programa, ainda maior, ainda mais contingente, tal como o risco de extinção de uma certa existência, à qual todos nós - aqueles que podem se colocar diante da questão "o que fazer?" - devemos ser tributários. Esse todos nós ainda mais contingente, me parece, só se sustenta se, de alguma maneira, aniquilamos as diferenças radicalmente irreconciliáveis, convocando todos nós a nos unirmos a uma só língua, um só coro, de nós contra eles [e aqui já caímos na contradição entre todos nós e nós contra eles].

Tal programa, agenda, regime talvez sirva a uma demarcação de uma teoria política ambiental, capaz de reunir povos e engajá-los por uma nova causa que demanda agora ainda mais cálculos, mas pouco tem a ver com uma mudança radical da política - do que entendemos como tal - pelo atravessamento do Antropoceno se assumido como uma hipótese [mais uma]. Porém é preciso ainda pensar a moral evocada mais uma vez no esquema fraternal político: estabelecer amigos-aliados, demarcar o inimigo e criar estratégias de guerra; todos em $\mathrm{Gaia}^{216}$; separar humanos e terranos; converter humanos em terranos; reconciliar a paz com Gaia, em Gaia. Essa é a moral política que ecoa de alguma maneira nesses textos de Latour: mais uma vez o sujeito, a demarcação de amigos e inimigos; mais uma vez o esclarecimento, o empoderamento pelo conhecimento; e mais uma vez a ação teleológica: unir todos a um nós pela permanência de nós sobretudo - de um certo todos nós já nos nós que criamos.

Penso essas questões já assombrado, outra vez, pela democracia por vir, pelo seu trabalho sem repouso, que tampouco se anuncia contra esses eternos retornos, nem contra as heranças da democracia nem as da amizade. Porém, se não reposicionamos essas questões iteravelmente, podemos estar mais uma vez alimentando uma teleologia da desigualdade e da repressão, que com o

\footnotetext{
${ }^{216}$ Aqui me refiro à hipótese elaborada por James Lovelock. Falarei mais adiante de como Latour pensa a aproximação entre Antropoceno e Gaia.
} 
pensamento de Jacques Derrida pode ser proposto ainda como um espectro do arquétipo falogocêntrico da fraternidade no político.

Desde o início, a democracia foi associada a valores, a axiomas, que pertencem a esse conceito canônico de amizade, que quer dizer irmandade, família, enraizamento em um território (autoctonia), Estado-nação (dependendo do território), solo e lugar etc. Agora, é possível pensar em uma democracia que poderia ser, então, se não ajustada, ao menos articulada a um outro conceito de amizade, uma outra experiência de amizade que não seria simplesmente dependente ou subordinado ao que chamei de conceito canônico prevalecente da amizade (falogocêntrico, masculino e assim por diante etc.) ${ }^{217}$.

O conceito canônico ao qual Derrida nos adverte está relacionado ao conceito de amizade política, que, em Aristóteles, é o segundo grau de amizade "baseada na utilidade e no proveito". A amizade política se distinguiria das outras duas: a alta amizade, "baseada na virtude", e a baixa amizade, "baseada no prazer" ${ }^{218}$. A partir desses rastros derridianos, poderíamos pensar que uma preocupação radical com o deslocamento efetivo sobre questões da política sem levar em consideração como esse "estar baseado em" é composto pode repetir uma mesma arquiteleologia falogocêntrica. A noção de amizade política aí se imprime já dentro da noção de irmandade, ou seja, uma aproximação entre iguais (homens - e não mulheres), filhos de um mesmo pai-mãe, capazes de deixar e reivindicar uma sucessão e herança [E aqui o espectro do patriarcalismo advindo do privilégio dos arcontes a que nos referimos anteriormente reincide mais uma vez]. Ser iguais como homem não quer dizer, porém, não haver uma amizade entre homem e mulher ou mulher e mulher, mas, sim, determinar que tais aproximações se dão marcadas por um laço anterior, que regula e determina a aproximação a distância. [A Orchesographie de Arbeau telecoreografa essa aproximação e distância entre corpos; marca bem quem tem a esgrima nas mãos e quem tem medo de ser cortado pela esgrima, como também marca quem tem medo de ferir com a esgrima; e marca os ensinamentos de uma certa regulação de movimento entre corpos, metodologia de um certa dança coreografada, por

\footnotetext{
${ }^{217}$ DERRIDA in BENNINGTON, 2004, p. 242.

${ }^{218}$ Idem, p. 239.
} 
recreação ou guerra, para bem posicionar esses lugares ${ }^{219}$.] Os fraternos devem ser iguais e honrar aquilo que os torna irmãos - o falo, o logos, deus, o Estadonação, o solo e, sobretudo, o nomos e o oikos que os acolhe. Talvez-sim, como uma hipótese, pensar esse falogocentrismo pode abrir rotas para outras políticas nos lembrando que certas heranças já imprimiram diferenças que não podemos quitar quando evocamos nenhum nós político.

Derrida pensa algumas tensões que se estabelecem a partir daí:

(...) deveríamos nós selecionar nossos amigos dentre os nossos aliados políticos? Deveríamos nós concordar politicamente com um amigo para iniciarmos uma amizade? Isso seria necessário? São política e amizade, ambas, homogêneas? Poderíamos nós ter um amigo que fosse, politicamente, um inimigo, e viceversa, e assim por diante? $?^{220}$.

Nessa brecha, abre-se o pensamento de outra ética-política, de partida, radicalmente a marcada pela alteridade, que aqui gostaria de lançar como desafio a se pensar, ainda à espera por vir da urgência do Antropoceno. Essa temporalidade por vir considera outras "composições" que exorbitam as assembleias em torno da urgência do Antropoceno: sem subjugar, sem reprimir, sem domesticar, mesmo que o Estado, o solo, agora pareça ainda mais abismal e também ainda mais abissal, com novos agentes inumanos e com os humanos sendo comparados àqueles que costumavam ser apenas seu cenário. Nessa outra temporalidade, não há moral que seja capaz de equacionar as desconexões e as infinitas dissidências [até mesmo as entre cientistas, entre humano e não humano etc.] porque o político - aquilo que nos urge a pensar-agir, aqui e agora, num

\footnotetext{
${ }^{219}$ Permitam-me citar mais uma vez a passagem a que estou me referindo e na qual já me demorei antes de Orchesographie. Deixemos ecoar outra vez o diálogo entre homens de direito, Arbeau a Capriol, clérigo e jurista. "Capriol - Eu muito apreciei a esgrima e o tênis, e isso me tornou amigável entre os homens jovens. Mas, sem o conhecimento de dança, eu não poderia agradar as donzelas, das quais parece-me depender toda a reputação de um jovem elegível/ Arbeau - Você tem toda razão. Tão naturalmente o macho e a fêmea procuram um ao outro, e nada estimula mais um homem aos atos de cortesia, honra e generosidade que o amor. E, se você deseja se casar, deve perceber que uma amante é conquistada pelo bom humor e graça exibidos enquanto dança, porque as senhoras não gostam de estar presentes em esgrimas ou tênis, para que um estilhaço de espada ou um golpe de uma bola de tênis não thes cause ferimentos. [...] o dançar é praticado para revelar se os amantes estão em boa saúde e de boa forma [sound of limb], depois que estão permitidos para beijar seus amantes, a fim de que eles possam tocar e saborear um ao outro; assim, podem verificar se eles estão em forma ou se emitem um odor desagradável, como de carne podre. Portanto, a partir deste ponto de vista, muito para além das muitas outras vantagens derivadas da dança, ela se torna um elemento essencial em uma sociedade bem ordenada" (ARBEAU, 2011, pp. 11-12).

${ }^{220}$ DERRIDA, 2004, p. 240.
} 
tempo de um já e também com vistas a um quando depois - passa a acolher uma alteridade de questões que sempre escapam, traem, escorregam. Assim, talvezsim, poderemos pensar a importante atenção que se coloca igualmente radical, catastrófica e naufrágica, aquando tomados pela chegada do Antropoceno [reafirmo, como hipótese].

Não há teleologia capaz de nos salvar de tal assombro. Não pensar radicalmente tal alteridade é praticar mera polícia, a meu ver, ou ainda estado de exceção que se confunde com um discurso de moral na política. Dar à moral uma estância reguladora para a qual podemos nos reportar, para aniquilar nossos conflitos e nossos inimigos, pode até não se anunciar como uma política de Estado, da soberania do Estado, mas se comporta como tal.

\footnotetext{
Trata-se de uma experiência contemporânea: sabe-se, entre guerras, depois da Primeira Guerra Mundial, já havia na Europa - e Hannah Arendt deu uma atenção especial a isto - uma infinidade de pessoas, nem sequer em exílio, nem sequer deportadas, mas apenas deslocadas, que não eram consideradas cidadãos, e, de acordo com Hannah Arendt, esta seria uma das origens do que aconteceu na Segunda Guerra Mundial. Esta não cidadania de pessoas com as quais devemos nos preocupar, as quais devemos acolher, nos urge, nos compele a pensar numa relação democrática para além do Estado-nação. Ou seja, a invenção de novas práticas, novo direito internacional, a transformação da soberania em Estado. ${ }^{221}$
}

Se, por um lado, o Antropoceno nos sugere uma espécie de möbius strip - imagem sempre evocada por Latour para performar a indecidibilidade entre o que habitualmente chamamos de natureza e cultura, terra e ação política - por outro, tomando essa mesa de trabalho, essa mesma metáfora-hipótese-subjétil, parece-me indispensável considerar que "corpos políticos” [sejam eles feitos de quaisquer enredamentos entre qualquer $n o ́ s^{222}$, até mesmo se assumirmos a hipótese do anthropos latouriano] podem ser pensados sem para isso evocar uma moral coletiva. É preciso resistir à necessidade de moral coletiva, em nome de um bem maior, como a chamada à responsabilidade advinda do temor da existência,

${ }^{221}$ DERRIDA, 1997 apud BENNINGTON, 2004, p. 245.

${ }^{222}$ Aqui mantenho a ambivalência da tradução do inglês para o português. Nodes como "os nós" que também pode ser um pensamento de nós (pronome) como amarrações - sempre muito frouxas, claro. 
que, mesmo dispensado de um certo cristianismo, ainda se comporta como um deus regulador, no sentido de eidos, ideia reguladora.

Se para Latour pensar corpos políticos e a agência entre esses corpos é pensar tal como a relação entre povo e entidade - como ele desenvolve ao longo das conferências de Gifford (2013) - me parece ser preciso cogitar outras governanças sem deus, sem lei, sem Estado, sem lugar, mas que também acontecem, tomam lugares, insurgem nos mais diferentes sítios, por vezes fora do centro das nossas atenções, fora dos arquivos e do poder dos arcontes e seus herdeiros fraternais, e que apelam outro tipo de responsividade; mais de uma, a um só tempo e sem dar lugar à redenção.

Nessa esteira, acompanharei as últimas observações de Latour, em Waiting for Gaia, e sua hipótese de Gaia, que a meu ver é uma Gaiareconciliadora ${ }^{223}$.

A primeira diz respeito à noção de Gaia em nós/nós em Gaia, que podemos ler como uma resposta adequada a um certo tipo de verdade que circula na comunidade científica, na economia de sua lei e residência que se mantém herdeira de múltiplas impressões (históricas, ontológicas, genéticas e teológicas) que a palavra ciência arquiva. Resposta adequada à arquiteologia que se funda na economia científica; lida com valores próprios, adequados, arquivados numa certa linguagem da comunidade científica. Responde ao(s) nós da ciência, gerando outros nós, gestos, gesticulações e gestações nessa superfície.

A chamada hipótese de Gaia $^{224}$, desenvolvida por James Lovelock a respeito do processo de homeostase da Terra como um complexo sistema de

\footnotetext{
${ }^{223}$ Gaia é o conceito ao qual Latour e outros pesquisadores dos science studies têm se referido para designar o que habitualmente se chama de Terra (planeta), levando em consideração as novas composições trazidas pela era do Antropoceno. Gaia não é o planeta Terra, mas o porvir da catástrofe que não comporta mais a noção de Terra como background da história humana. Meu argumento irá apresentar esse conceito singular, via Latour, tal como ele aparece em Waiting for Gaia (2010). Não pretendo aqui reduzir a noção de Gaia nessa exposição, até porque ela é uma proposição que sempre está sendo reelaborada pelos science studies. Minha análise se restringe pontualmente ao texto Waiting for Gaia, no qual, como veremos mais adiante, Gaia ganhará feições de uma entidade reconciliadora.

${ }^{224} \mathrm{E}$ me parece importante chamar atenção novamente à ambivalência que qualquer hipótese performa na sua dação e lance, para não cairmos num certo gaísmo. Lovelock a intitula assim: hipótese de Gaia.
} 
forças integrantes das condições climáticas e organismos biogeoquímicos, problematiza a ciência que olha para o espaço como ponto de fuga infinito. Gaia traz a necessidade do mundo sub-lunar e de sua urgência para a localidade na linguagem da ciência. Nesse sentido, talvez, Gaia pode ser uma resposta, uma estratégia, de redimensionamento das questões científicas sobre o clima.

Latour (2011) aponta quatro questões a respeito de Gaia como um aliado da causa climática. A primeira delas diz respeito à afirmação de que Gaia não se aproxima em nada ao conceito de natureza como um infinito. Gaia não é natureza porque ela é local e singular, somente possível no mundo sublunar: “(...) apenas robôs e talvez um punhado de astronautas-ciborgues podem ir mais longe e além, mas que o resto da raça, nove bilhões de nós, permanecerá preso aqui embaixo... Não mais além ${ }^{225}$. Não mais fora" 226 .

A segunda se relaciona a uma contradição interessante. Ao mesmo tempo, há uma indiferença e uma extrema sensibilidade entre Gaia e a vida humana. Ou seja, suas infinitas redes de remodelação podem provocar a extinção de um certo nós ao passo que cria dívidas a qualquer um de nós. Nessa esteira, os efeitos em Gaia não são dominados pelo sujeito, mas são um assujeitamento.

A terceira: Gaia não é nenhuma entidade "mística" - não podemos (ou não deveríamos) nos referir a ela como um deus, alimentá-la como um deus, esperando ser recompensados ou perdoados por ela ou ele.

Até onde posso imaginar, Gaia é apenas um conjunto de laços [loops] cibernéticos contingentes positivos e negativos, como demonstrado no famoso modelo do "mundo das Margaridas"227. Acontece que esses laços tiveram um efeito completamente inesperado, um após o outro, e aceleram as condições para novos loops positivos e negativos de complexidade cada vez mais enredada. Não há teologia, não há providência divina em tal argumento ${ }^{228}$.

\footnotetext{
${ }^{225}$ Particularmente, essa contratranscendência me soa um pouco estranha ou talvez pouco interessante. Sim, entendo a necessidade do local e todas as suas implicações, mas também acho que toda localidade guarda rotas de fuga. A necessidade do local está aberta, desde as suas margens, para além, portanto, para a chegada do outro, do acontecimento, do porvir.

${ }^{226}$ LATOUR, 2011, p. 9. Grifo meu.

${ }^{227}$ Alyne Costa, em sua livre tradução, esclarece em nota de rodapé: "Mundo das Margaridas (Daisyworld) é o modelo matemático usado por James Lovelock para ilustrar a teoria de Gaia, segundo a qual 'o sistema da Terra se comporta como um sistema único e autorregulador composto de componentes físicos, químicos, biológicos e humanos (Declaração de Amsterdã, 2001)"'.

${ }^{228}$ LATOUR, 2011, p. 10.
} 
Latour prossegue afirmando, portanto, que Gaia é um conceito "científico", mas não num sentido epistemológico, ressalta. Sobre o sentido “científico", Latour diz:

Eu o entendo de uma nova maneira, e de certa forma no velho sentido, de "científico" como um termo cosmológico (ou melhor, uma cosmopolítica) que designa a procura por, assim como a domesticação e a acomodação de novas entidades que tentam achar seu lugar no coletivo somando-se aos espaços dos humanos, muitas vezes deslocando estes últimos. O mais interessante sobre Gaia de Lovelock é que ela reage, sente e pode se livrar de nós, sem ser ontologicamente unificada. Não é um superorganismo dotado de um poder de ação unificado. É exatamente esta total falta de unidade que torna Gaia politicamente interessante. ${ }^{229}$

Latour entende Gaia politicamente interessante, evitando ao máximo possível, dentro da sua resposta adequada, qualquer personificação dela. Apesar disso, admite alguma subjetividade psíquica - mesmo que ilustrativamente - , sobretudo quando aceita a formulação de Lovelock a respeito da vingança de Gaia $^{230}$ e a noção de domesticação e também quando diz, no final de seu artigo, que a proposta do Science Po é buscar estratégias de acordo com Gaia, acreditando que no fim haverá alguma redenção. Para uma certa comunidade técnico-científica que precisa estabelecer cosmogramas realistas e ter alguma perspectiva de futuro, esse interesse político de Gaia pode ser performativamente feliz; pode produzir algum efeito de discurso. Resposta adequada a uma ciência que se excita cada vez que nós hipertrofiamos mais e mais a nossa capacidade cognitiva de apropriação, domesticação e acomodação do mundo, cálculo, visualização, perspectivação de rotas, saídas e até redenções.

Gaia responde cientificamente que, mesmo com tanta confusão e dissonância entre os nós da ciência, há algo ainda maior que reúne todos nós, e esse algo não é um deus, mas é um algo que ainda porta em si um certo theos/telos vingativo. Há agora uma nova razão para convocar um certo nós - uma comunidade científica - a unir-se. Essa razão, dessa vez, é catastroficamente construída, por muitas tecelagens, maior que todas as outras, porque se trata do fim de uma espécie, do suplício de uma espécie, e não qualquer espécie, mas

\footnotetext{
${ }^{229}$ Idem.

${ }^{230}$ Sentença que nomeia um dos últimos livros de Lovelock, que aborda as atuais circunstâncias do aquecimento global como uma reação de Gaia.
} 
aquela capaz de reunir e atar quaisquer nós, sobretudo os do nós humanos contingência que nos diz que sem ela não há ciência, não há política, nem mesmo ser.

Nesse sentido, adaptando o catastrofismo esclarecido de Günter Anders $(1960)^{231}$, Latour pensa Gaia como uma hipótese que exige um trabalho sobre ela, tendo esse gesto como um dispositivo profilático: exercitar o fim para que o fim não aconteça. É essa profilaxia que prepara o terreno para responder a pergunta de escala formidável lançada em Waiting for Gaia (2011): o que fazer diante de um problema tão grande? E ele responde: "ter esperança”. Essa é quarta e última questão apresentada por Latour sobre Gaia como “the last trick!” - preferiria não traduzir essa sentença para manter ainda alguma ambivalência.

A esperança, para Latour, tem a ver com tentar negociar com Gaia essa coisa estranha que não pode ser uma entidade mítica, mas pode ser negociável, esperando no fim alguma redenção. Para Latour, esperança só é possível se houver uma cosmopolítica radical que parta de uma crença em que tudo que era meramente simbólico, no Antropoceno, passe a ser compreendido como modelagem da terra, literalmente. Podemos acompanhar essa curiosa redenção negociativa em:

\begin{abstract}
Afinal, isso é justamente o que se entende pelo conceito de Antropoceno: tudo o que era simbólico é agora para ser tomado literalmente. Culturas usadas para "moldar a Terra" simbolicamente; agora elas fazem isso para sempre. Além disso, a própria noção de cultura se foi junto com a de natureza. Pós-natural, sim, mas também pós-cultural ${ }^{232}$.
\end{abstract}

A travessia da ponte entre o radical ceticismo da ciência e a esperança de reconciliação com Gaia, para Latour, estaria em preencher a lacuna entre os estados emocionais e cognitivos, "para atender ao chamado da responsabilidade

\footnotetext{
${ }^{231}$ Anders escreve sobre a noção de catastrofismo esclarecido na década de 1960, pensando como a era nuclear criou um abalo no regime metafísico e na própria ontologia, a partir do momento em que a radicalização do fim - sem herdeiros para contar a história - tornou-se possível. Em suma, trata-se da discussão do poder demasiadamente humano que não produz uma absolutização da história, mas a degradação da história e, em última instância, a degradação do conhecimento, pois, uma vez utilizado - se alguém apertar o botão - não há possibilidade de reversão nem mesmo de transmissão ou herança de tal ato. A noção de catastrofismo esclarecido não se trata de um simples niilismo, mas busca experimentar o fim ao máximo para também evitar ao máximo a catástrofe que está por vir e que é incondicional, Cf. ANDERS, G. Le temps de la fin. Paris: L'herne, 2007.

${ }^{232}$ LATOUR, 2011, p.11.
} 
sem cair na negação ou melancolia" ${ }^{233}$. É nessa tentativa que seu programa Science Po, diz ele, tenta "ressuscitar o tão antiquado termo de artes políticas", para "treinar artistas profissionais e cientistas (sociais e naturais) para a tarefa tripla de representação científica, política e artística" ${ }^{234}$.

Chegamos então ao momento em que a cosmopolítica evocada por Latour me parece mais uma vez recair sobre o risco de replicar as políticas do sujeito esclarecido, as quais mantêm a lógica de distanciamento entre ação e superfície, dessa vez aderindo também à arte. Devo dizer, primeiramente, que reconheço uma importante potência na proposta do Science Po de trabalhar no atravessamento entre ciência, política e artes. Porém, mais uma vez, e para o desespero de alguns, a noção de artes políticas que Latour parece adotar - ao menos em Waiting for Gaia (2011) - recai sobre o viés de emancipação do sujeito pela experiência estética ${ }^{235}$. Agora a causa não é mais a luta de classes, mas, sim, uma guerra de mundos ainda mais contingentes da qual precisamos, todos nós, nos salvar. A direção está dada desde o colocar-se diante do "o que fazer?" e reafirmada pelo esclarecimento, que acolhe muito bem as noções de treinamento e tripla representação (científica, política e artística).

Latour arremata o seu texto pensando numa política de esclarecimento e redenção, positivando a arte como um dispositivo de redistribuição de tarefas, agora regulada por outra causa maior: a urgência do fim que pode unir a todos nós. Essa pode ser uma armadilha bem inadequada, uma old fashion trick, que toma a arte como um dispositivo político de maneira muito restrita e indigesta, a meu ver. Os atravessamentos entre política, ciência e artes são sempre catalisadores - convocam muitas mãos de trabalho. Mas me parece que, pela mesma força de sua catalisação e também capitalização, é preciso fazer alguma resistência às tecelagens que se compõem a partir daí.

Latour não desdobra nesses textos analisados aqui a ideia de tripla representação que seu programa Science Po quer treinar, mas há algumas pistas que deixam escapar a maneira como ele toma a arte como um dispositivo político, sobretudo ao se referir às obras de artistas - bem específicos - para ilustrar suas

\footnotetext{
${ }^{233}$ Idem, p. 12.

${ }^{234}$ Ibid.

${ }^{235}$ Claro que esse texto não encerra toda a proposição que segue em desenvolvimento no Science Po. Essa é uma reflexão assumidamente pontual. E a escolha de Latour é ainda estratégica, local... não estamos aqui ontologizando seu pensamento em démarche.
} 
questões: as interpretações sobre os poemas de Shelley, para falar da impossibilidade do sublime; os filmes Melancolia (2011), de Lars von Trier, e Avatar (2009), de James Cameron, para falar do sentimento de esperança, negação e melancolia quando estamos diante do fim inevitável; e o quadro do Mestre de Messkirch na Basileia no qual São Cristóvão segura Cristo, para ilustrar uma possibilidade de redenção de Gaia; entre outras.

Em Latour (2011), essas obras são analisadas a partir mais da temática que parecem tratar do que dos modos de composição e de como estes remodelam as formas de nos reunirmos para além do logos. As composições dessas obras são interpretadas somente a partir do tipo de narrativa que nos contam, na medida em que elas têm alguma afinidade temática com o Antropoceno. Obras magníficas para forçar um termo de escala formidável [ele arquiva alguma relação com a pergunta "o que fazer...", arrisco em dizer], sem dúvida. Mas podemos dispensar as economias que circulam com essas obras para além de suas narrativas? Essas obras circulam, dão acesso a todos nós, ainda todos nós em Gaia e da Gaia em todos nós?

No que se refere aos modos de composição entre arte e política, Latour (2011) parece ainda manter-se sob os paradigmas da universalidade iluminista, tal como apontado por Jacques Rancière em The Misadventures of Universality $(2008)^{236}$. Aqui, estrategicamente, irei trazer à tona apenas algumas observações dessa contribuição de Rancière que nos ajudarão a provocar alguns desvios na discussão entre arte e política; e também gerarão atalhos para as discussões seguintes.

Para Rancière, a noção de desmascarar fantasmas está impregnada de uma concepção de verdade oculta, subterrânea, mais verdadeira que todas, que corrói o tecido social e, por isso, seguindo o argumento universal-contingente, precisa ser desvelada à luz da razão. O desvelamento dessa verdade corrosiva está, por sua vez, associado à noção de empoderamento advinda da crítica, capaz de

\footnotetext{
${ }^{236} \mathrm{O}$ texto discute a universalidade na arte, analisando a Bienal de Sevilha, The Unhomely: Phantom Scenes in Global Society (O Estranhamento: Cenas Fantasmas na Sociedade Global). [Tradução minha].
} 
retornar uma experiência total da verdade, uma concepção universalista de verdade. Essa concepção, presente nos mais diversos pensamentos sobre política, passa então a privilegiar experiências estéticas que promovem um tipo de esclarecimento sobre uma realidade social contingente - que Rancière destaca ser normalmente hoje relacionada à sociedade de consumo advinda de um período pós-industrial/pós-capital [mas que aqui poderíamos também pensar no sentido da contingência geopolítico-social desenhada pela cosmopolítica de Latour].

Rancière escreve que estamos vivendo outro tipo de descolamento, ou crise, que diz respeito à dissociação entre poder e razão:

O que nós estamos enfrentando hoje é a decomposição do modelo de crítica social, e mais amplamente o modelo Iluminista de ação e empoderamento pelo conhecimento. Segundo esse modelo, era o poder da razão que desmascara o fake universal e descobre deste modo a única verdade: por exemplo, a universal lei da estrutura social por trás da universalidade oficial sobre leis jurídicas e políticas. Como a verdade universal era mais abrangente, mais poderosa que as outras, a abertura produzia um efeito de empoderamento. Por exemplo, a fotomontagem ${ }^{237}$ que desvela a realidade sobre a guerra imperialista e a violência escondida por detrás do discurso de paz e de conforto do território americano, ou a realidade sobre lucro e consumo burguês por detrás da cruzada "free world", era para empoderar uma consciência sobre os conflitos e contradições do mundo, deste modo alavancando uma energia para ação e transformação ${ }^{238}$.

Segundo o autor, o discurso da universalidade que sempre esteve ancorado no entrelaçamento entre poder e razão, agora, na atual crise [que, nessa passagem, nada se refere às questões ambientais, mas ainda diz respeito aos atuais suplícios de uma contingência, seguidos da pergunta “o que devemos fazer?”], razão e poder aparecem em dissenso. A razão continua sendo usada para "revelar o funcionamento da máquina, a lei do poder de consumo atrás das suas máscaras", mas também criou uma síndrome patológica de impotência gerada por discursos políticos polarizados (esquerda e direita) que o autor chama de "fúria direitista" e "melancolia esquerdista" (right-wing rage/left-wing melancholy).

\footnotetext{
${ }^{237}$ Rancière aqui está se referindo à série Bringing the War Home, de Martha Rosler, exposta na bienal, criada durante o período de guerra no Vietnã, na década de 1970, que mostra um conjunto de colagens do ambiente familiar norte-americano sendo invadido por imagens do conflito armado. ${ }^{238}$ RANCIÈRE, 2008, p. 73.
} 
A primeira, fúria direitista, aparece da avassaladora hiperpotencialização da noção de democracia (consenso entre diretos humanos + mercado livre + livre escolha individual), que entende igualdade democrática como igualdade entre comprador e vendedor de qualquer mercadoria. "O indivíduo democrático quer o triunfo do mercado em todas as esferas de sua vida. E o mais igualitário para ele

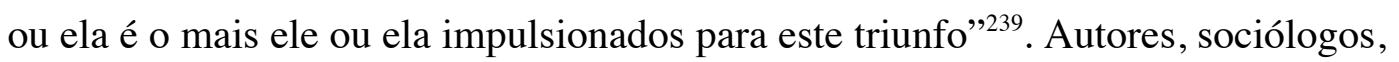
pensadores, políticos e moralistas se debruçaram então a falar dessa fúria, professando que a desastrosa situação de crise em curso é consequência da necessidade desse consenso democrático e por isso justifica-se todo e qualquer terror, guerra, pobreza etc. Para estes, resta lamentar o desastre já dado e “o prazer secreto de comprovar que os surdos estão surdos como eles disseram" ${ }^{240}$.

Já a melancolia esquerdista cresce na afirmação do que o autor chama de “império panóptico sobre os indivíduos", em que todos participam de um novo jogo universal disponível: nós estamos dentro da barriga da besta (o tal sistema), e toda e qualquer ação é parte desse jogo. Na previsão melancólica, o que é professado "é justamente sobre a mentira ocultada sobre qualquer verdade. É apenas dizer: "- as coisas não são como vocês pensam que são". Como uma proposição que nunca poderá ser refutada. Melancolia, como profecia, cresce na sua impotência" ${ }^{241}$. Qualquer interpretação crítica sobre o sistema opera dentro do jogo já dado (a "barriga do global beast"), portanto parte do sistema.

Rancière irá concluir dizendo que um primeiro escape está no abandono das noções de global beast, "império", "maquinaria global”, "necessidade histórica marxista" etc. Dessas noções, desencadeia a lógica de dominação que parte de um "consenso", que Rancière lembra não operar somente na arbitrariedade da construção de acordos para fugir dos conflitos, mas, sobretudo, no acordo entre o que percebemos e o sentido do que percebemos, entre possibilidade e impossibilidade nas determinações das coisas. Sendo assim, evocar o dissenso e seu "contentamento positivo" (que entendo ser de caráter disseminativo $^{242}$ ) surge como um escape da impotência política e sua fantasmagoria atual.

\footnotetext{
${ }^{239}$ Idem., p. 74.

${ }^{240}$ Idem., p. 76.

${ }^{241}$ Idem, p. 77.

${ }^{242}$ Aqui remeto ao movimento disseminativo da différance derridiana e sua potência de arrombamento de qualquer tentativa de retorno, reunião ou totalização da noção de $U m$. Em
} 
O dissenso começa com o contentamento opositivo: não existe uma realidade. A certeza que está para implicar tais possibilidades e impossibilidades é controversa a elas mesmas. Isto é o que a subjetivação política é: a partilha da unidade do dado e da evidência do visível, e consequentemente, da possibilidade. Ela nos diz sobre essas várias invenções de conflito no mundo em um e o mesmo mundo está emoldurado pelo consenso. Na minha visão, o primeiro escape da lógica de consenso é escapar da configuração do dado que nos instiga a pensar em dissenso como êxodo. Este é o escape da dramática divisão entre in e off. Devemos nos livrar dessa lógica consensual de global e histórica necessidade. Haverá forças e conjunção de forças que emolduram cada e cada mundo, cada e cada configuração de possibilidade e impossibilidade ${ }^{243}$.

Seguindo o pensamento de Rancière, o tipo de contribuição que as configurações estéticas dão à atual conjuntura não consiste em mais uma vez recair sobre a tentativa de esclarecer o sujeito sobre tal contingência. A experiência estética compõe ainda mais dissensos, embaralha ainda mais as cartas do jogo: eis a sua força de composição política - ao mesmo tempo reunir e dispersar. Nesse sentido, me parece que qualquer convocação sob as vestes de uma teleologia da representação pode, por vezes, assolar e despotencializar os modos de composição política nas artes, sobretudo quando trabalhadas, didaticamente, com interesses in-formativos. Por isso que pensar a arte como estratégia de assembleia em torno de uma causa ou causas, sobre nós, a meu ver

Posições (2001), Derrida define sua noção de disseminação como a différance seminal que se difere da noção de polissemia, portanto ultrapassando o sentido de teor conceitual. Em outras palavras, disseminação não se reduz a questão semântica: "Se não se pode resumir a disseminação, a différance seminal, em seu teor conceitual, é porque a força e a forma de sua ação perturbadora fazem explodir o horizonte semântico. A atenção dada à polissemia ou ao politematismo constitui, possivelmente, um progresso relativamente à linearidade de uma escrita ou de uma leitura monossênica, ansiosa de amarrar o sentido tutelar, ao significado principal do texto, até mesmo ao seu referente primordial. Entre tanto, a polissemia enquanto tal organiza-se no horizonte implícito de uma retomada unitária do sentido, até mesmo de uma dialética (...) teleológica e totalizante que deve permitir a um momento dado, por mais distanciado que ele seja, de voltar a reunir a totalidade de um texto na verdade de seu sentido, constituindo o texto em expressão, em ilustração, e anulando o deslocamento aberto e produtivo da cadeia textual. A disseminação, ao contrário, por produzir um número não-infinito de efeitos semânticos, não se deixa reconduzir a um presente de origem simples ("A disseminação", "A dupla sessão", "A mitologia branca" [textos de Derrida] são re-colocações práticas - de todas as falsas partidas, de todos os começos, incipts, títulos, exergos, pretextos fictícios etc.: decapitações) nem uma presença escatológica. Ela [a disseminação] marca uma multiplicidade irredutível e gerativa. O suplemento e a turbulência de uma certa falta fraturam o limite do texto, interditam sua formalização exaustiva e clausurante ou, ao menos, a taxonomia saturante de seus temas, de seu significado, de seu querer-dizer" (DERRIDA, 2001b, pp. 51-52, grifos do autor, comentários entre colchetes meus). Acredito que tal força irredutível e gerativa se aproxima da noção de dissenso pensado por Rancière. Retomemos.

${ }^{243}$ RANCIÈRE, 2008, p. 80. 
pode subjugar os processos artísticos, revertendo-os em dispositivos de modulação de um projeto de sujeito que só se justificam em nome de uma moral coletiva.

Haveria uma outra potência política em obras de arte, talvez, na medida em que elas são também formas de assemblage que não estão necessariamente vinculadas a uma temática. Quando vinculadas a uma temática, intencionalmente constituídas para tratar de algo, não as vemos com fins de regularização moral sobre (os) nós [jogando aqui com a dupla ligadura entre pronome e substantivo]. O risco da temática ou assunto comum, o estabelecimento de um comum, não dá mais conta da outra urgência que é o fim do fim, o fim do telos regulador dos processos artísticos, o que tenho acompanhado entre algumas produções de arte contemporânea e também alguns modos de pensar trazidos pela arte contemporânea, que redimensionam a forma de estar compondo as espacialidades com as artes.

A estrutura autocentrável do discurso narrativo mantém o mesmo código do perspectivismo, do sublime moderno, que cria diante de nós uma promessa de objetos ainda mais sofisticados que nos coloca muito pequenos frente a ele. Criar uma supernarrativa, por exemplo, para convocar o público a refletir sobre a causa da crise climática pode até informar sobre, a respeito de, aumentar ainda mais o sentimento de culpa frente a tal monstruosa vingança de Gaia, mas pouco tem a ver com a desconstrução do sublime e pouco provoca abalos nos modos de composição política das artes. Ao contrário, é a promessa do hipersublime, dado pela genialidade de um artista - ou uma equipe de artistas e cientistas - que pode produzir cosmogramas [usando uma noção pensada por Latour] ainda mais miméticos, ainda mais realistas: não só falamos do humano na Terra, dos problemas da condição humana no solo, mas agora também falamos do solo; do solo como sujeito, tal como fazíamos com o humano. Porém, com Rancière, poderíamos perguntar: mas essa seria uma exclusividade do tempo antropocênico? Não seria a potência da performatividade das obras, uma partilha já do político?

Obras de repertório do balé romântico, reencenadas até os dias de hoje, como $O$ Lago dos Cisnes e A Silfide, por exemplo, há alhures, já não performam um jeito de estar no ambiente muito próximo ao modo de lidar com informações, objetos, coisas, corpos e outros nós, construindo espacialidades numa contingência? A organização do cenário, com grandes painéis estáticos, até as 
hierárquicas formas/desenhos no espaço, a busca cada vez mais harmônica e simétrica entre cada gesto etc., a paixão impossível entre Odete e Siegfried prometida no programa de repertório romântico já não formam uma comPosição política? Se trocássemos a historieta fabulosa por outra mais atual e contingente, seríamos provocados a pensar outra maneira de compor o estar com e de partilhar o sensível? Suspeito que não temos como dar uma resposta cabal a essa pergunta, pois está lançada aí uma questão incalculável. Nunca sabemos com total precisão o querer-dizer de uma obra, os desdobramentos de seus efeitos e suas conjurações no tempo. Acredito que somente insistindo nesse escape irredutível poderemos continuar pensando na política que atravessa os processos artísticos sem que para isso estejamos determinando novos rumos, telos ou paradigmas estéticos que antecipem suas com-posições.

Porém será que a questão fantasmática estaria encerrada, como parece sugerir Rancière? Haveria outra maneira de falar de fantasmas na arte sem cair nas misadventures ansiosas de iluminação? As heranças de Marx [e também de Freud que pensou de forma muito rigorosa os processos alucinatórios, os fantasmas do inconsciente] e suas conjurações espectrais estariam esgotadas? Quem de direito poderia afirmar uma questão como essa? Que justiça se pretende nesse enunciado?

Aqui se inscreve o meu interesse particular pela dança e pela performance para além do fato de eu participar de um certo circuito de pesquisa e de criação artística que envolve essas duas singularidades. Acredito que a dança e a performance [em algum momento, podem ser confundidas como uma mesma coisa, mas por historicamente constituírem circuitos distintos é, estrategicamente, importante afirmar suas diferenças ${ }^{244}$ ] engendram uma força radical de fugitividade, e as noções de conteúdo ou mensagem não resistem à performatividade de seus rastros nada muito constativos. Talvez seja somente possível falar de uma ação constativa em dança, aqui no sentido mais radical do

\footnotetext{
${ }^{244}$ Há algumas discussões latentes do campo dos performance studies em torno da afirmação da singularidade da performance (desde a palavra). Alguns autores (Phelan,1997; Taylor, 2013) pensam a negatividade da performance, o seu desaparecimento irredutível, como um certo apelo ao anarquivismo da performance. Na dança (que é incorporada como parte do citado campo de estudos), também ecoa o apelo ao anarquivismo, sua efemeridade, mas ao mesmo tempo, depois de pensarmos a relação entre coreografia como método de repetição e transmissão de legado, herdado por Arbeau, que replica uma noção de arquiescritura, já não podemos seguir com nenhuma noção de pleno anarquivismo sem admitir sofrer do mal de arquivo proposto por Derrida (2001). Na seção seguinte, retornarei ao problema do arquivo entre dança e performance.
} 
pensamento austiniano, se levarmos cegamente a sério o tratado e a promessa do pensamento moderno de coreografia como máquina restituidora de um movimento originário. Porém, como já vimos com Lepecki (2006), não podemos esquecer que essa noção só será efetivamente possível através da virtualização de um certo solipsismo do bailarino [que nunca foi qualquer corpo que dança], que em seu estúdio/quarto isolado replica a habilidade de grafar e restituir movimentos na ausência de seu mestre. Tal virtualização, por sua vez, só é possível se também repetível: o coreográfico se replica pela virtualização de transposição, do corpo para o grafo no papel, da experiência bidimensional para o fundo da ambiência coreográfica. Nesse jogo entre virtualização e repetição, o solo que se constitui é assombrado por uma memória de espacialização que, a depender da promessa ética que se faça, torna-se um guia para a execução de um roteiro de "passos" ou de "passagens" de uma posição para outra, de uma força para outra.

Porém, até mesmo nos casos de danças que apresentam um vocabulário e também uma gramática bem definida que determinem deslocamentos quase que matematicamente calculados, a performatividade dos corpos dançantes, ao executarem sua ação, traem qualquer restituição fiel à coreografia e fazem tremer o sentido de coreografia como uma lei imune que aciona o originário imutável. $\mathrm{Na}$ performance de uma dança, os elos entre memória, roteiro e execução são mantidos apenas como estado de promessa de fidelidade. Se reúnem ao mesmo tempo que se distanciam, escapando do fantasma da restituição.

Fantasmas de fantasmas de fantasmas... ainda não temos como não ser perseguidos por eles. Telecoreograficamente falando [se puder arriscar esse ato de fala], a mais rigorosa coreografia está submetida à temporalidade espectral da dança: aparição e desaparição, repetição e escape, iterabilidade por vir e disjunção injuntiva do tempo out of joint [para usar uma expressão de Hamlet retomada por Derrida na sua leitura de Marx].

É preciso falar de assombros e fantasmas sem precisar prestar contas a um telos representativo de causa política. Há alguma aproximação interessante que ainda resiste entre as composições políticas nas artes através dos seus modos de partilha e de espacialização, suas arquiteturas encenadas como efeitos de localidade em público e os desajustes e as disjunções engendradas pelo tornar-se público de uma obra, sobretudo de uma que seja lida como um evento, uma performance, sem que isso signifique sair do secreto para o não secreto. O tornar- 
se público não tem a ver com o processo de espetacularização do social, tal como pensado por Guy Debord (1997), como a reversão de toda a experiência comum engendrada pela economia das imagens. Ao contrário, a alteridade do público adia o encerramento dessas arquiteturas na relação do "olho retínico", como diria Duchamp, ou do que se pode "calcular e antecipar pela visão", diria Derrida (2012), uma vez que o tornar-se público necessita mais do que uma relação a dois de sujeito e objeto, impossibilitando o processo de acumulação plena. É exatamente porque o evento se dá na espacialização incondicionalmente pública, no tornar-se público - que não significa se dar às luzes; a publicidade do público não é privilégio das luzes - que a resistência à captura e à acumulação pode emergir. É no tornar-se público de um evento que a partilha do segredo resiste. Uma certa impossibilidade de lição, de um bem saber viver, de um bem saber lidar com a vinda que vem já de partida. No desajuste irremediável de posição sem repouso, a experiência pública performa aí uma turbulenta força fraca.

Tal turbulenta força fraca anuncia outra noção ético-política do evento. É o que pensaremos, a seguir, com Derrida e seus espectros de Marx e de Freud, e também seus espectros de dança. 


\section{No Rastro da Força Fraca: Performance, Espectralidade, Economia Circular e Turbulência}

The time is out of joint.

W. Shakespeare.

O futuro pertence aos fantasmas.

J. Derrida.

Duas epígrafes telegráficas abrem esta seção e nos lançam à questão de desajuste/disjunção do tempo. A primeira delas, a de Shakespeare, é também a epígrafe de Espectros de Marx (1994), de Derrida, e uma das afirmativas mais enigmáticas lançadas em Hamlet. Já evocou muitas discussões de tradução e convoca a reaparição da relação entre materialidade e tempo, não somente em Derrida, mas também em Marx e outros. A segunda, a de Derrida, é uma das falas do autor no filme Ghost Dance (1983), que também tomei nota por uma epígrafe de um texto de Jennifer Blessing ${ }^{245}$. Epígrafes de epígrafes, incorporações de incorporações... movimento singular dessa parte do texto que o antecede, logo abaixo do título ${ }^{246}$, invocando uma memória, um suplemento, anunciando uma futuridade ao mesmo tempo que retoma um passado, uma herança que se guarda de cor, uma retomada de cor. Essas duas epígrafes, em especial, são incorporadas aqui para retomar o problema da espectralidade que guardam uma na outra.

Acompanhemos algumas passagens de tradução de Derrida, em Espectros de Marx (1994), do The time is out of joint, atravessado por Marx e Hamlet: "a fórmula fala do tempo, ela diz também $o$ tempo, mas se refere

${ }^{245}$ Cf. BLESSING, J. Revenant Images: Memory's trace in postwar art. IN: GUGGENHEIM Museum. Haunted: contemporary photography, video, performance. New York, 2011, pp. 14-49.

${ }^{246}$ Essa palavra que já não podemos mais enunciar sem pensar na sua economia paradoxal de valor. 
singularmente a este tempo, a estes tempos, a um 'por estes tempos', o tempo dos tempos, o tempo deste mundo que foi para Hamlet um 'nosso tempo', simplesmente 'este mundo de agora', esta época e nenhuma outra" ${ }^{247}$. Mais adiante, sobre essa condição de mundo como tempo, Derrida também lançará uma outra tradução: "O mundo vai mal. Está desgastado, mas seu desgaste não conta mais. Velhice ou juventude - não se conta mais isso. O mundo tem mais de uma idade. Falta-nos a medida da medida. (...) O que vem, ou parece intempestivo, acontece ao tempo, mas não acontece a tempo. Contratempo. The time is out of joint ${ }^{, 248}$.

Derrida traduz essa disjunção/desajuste do out of joint do tempo ora como a experiência de mundo — de um agora de mundo, mas também de muitas idades - , ora como intempestividade, a sua vinda que acontece ao tempo, mas já fora do tempo, já sempre atrasado. Diz contratempo. É no contratempo da vinda como já passagem, como a matéria-tempo, a duração, de um fantasma que podemos falar de um estado atual das coisas, como o tempo de "conjurar espectros" - convocado por Marx e Engels no Manifesto Comunista, de 1848. É também nessa disjunção de tempo que se pode problematizar a questão da presença e da presentidade do presente, como Derrida irá formular, de passagem, no filme Ghost Dance: "o futuro pertence aos fantasmas". Essa outra futuridade se coloca como a vinda do que vem, como a de um espectro, mais radical que o esquema de projeção da presença, de um futuro-presente; ela evoca um porvir do tempo que não se pode prever desde nenhum agora, mas que vem sempre como um “outra-vez-outro". Para essa temporalidade lançada à iterabilidade desde sua inscrição, nos falta medida, nos falta sempre, sempre e outra vez, a justeza da medida, "a medida da medida" - diz Derrida. Outra vez porvir, outra vez justiça, outra vez espectros.

Quantas repetições! Retomemos a última delas: "espectro" — que não é espírito, mas, sim, sua forma-aparição de materialidade desmaterializada ${ }^{249}$ : “o

\footnotetext{
${ }^{247}$ DERRIDA, 1994, p. 73.

${ }^{248}$ Idem, p. 107.

${ }^{249}$ Discutiremos essa formulação que ecoa Marx mais adiante, a qual Derrida também faz tributação em Espectros de Marx. Peço que o leitor tome nota que Espectros de Marx (1994) é uma obra muito lida entre os estudos de Derrida. Ela reúne uma conferência proferida pelo autor em duas sessões, em 1993, na Universidade da Califórnia (Riverside), para abrir o seminário Whither Marxism? - "título brincalhão e ambíguo", diz o editor ( $c f$. Derrida, 1994, p. 6), que pode ser traduzido como "Para onde vai o marxismo?" e também, sub-repticiamente, "O marxismo está aparecendo (whither)?”. A resposta dada por Derrida às dobras de Whither Marxism? é
} 
espectro é uma incorporação paradoxal, o devir-corpo, uma certa forma fenomenal e carnal do espírito. Ele se torna, de preferência, alguma 'coisa' difícil de ser nomeada: nem alma nem corpo, e uma e outra" 250 , diz Derrida.

Tenho repetidamente falado de espectralidade nesta escrita, seguindo e sendo perseguido por assombros — inflexionei essa palavra muitas vezes, por sua ficção, sua chamativa. Talvez tenha sido uma estratégia, como a de um prefácio ou a de uma epígrafe para a formulação do que se seguiria depois, aqui-e-agora. Sumariamente: não somente as fábulas e as ficções, mas também as danças, acredito, têm uma chamativa, uma injunção política ou, ainda, uma dis-junção social do vem que se dá na desaparição de seu rastro enquanto dança. Um paradoxo perturbador como sempre déjà $v u$, “esse mal-estar da percepção, da alucinação e do tempo"251. A duração de uma dança tem um apelo do vem, de só se materializar já incorporado na memória, jamais sendo um objeto da memória, e desaparecer. Siga-me!, apela o vem da dança, seguido de um guarde-me, adeus!

Há algum tempo, venho preparando esse apelo do vem da dança, que não fala de nada, não se enuncia como um logos, mas chama para uma experiência de quando estar junto, do seguir um movimento, mesmo sem a ele pertencer, mesmo que mantendo a incondicional distância de seu chamado - seja quando se testemunha uma dança, seja quando se dança sua promessa. No rastro desse chamado, há uma força de convocação sem nenhum sentido em si, sem dar nenhum sentido em si, que vem apenas como um vem! e que aqui pode abrir uma khora para se pensar "o tempo do aprender a viver", "do estar-com" e do "estado de dívida" que atravessa a política da memória, da herança e das gerações problemas pensados por Derrida como questões da espectralidade.

extensa e geradora de muitas discussões a respeito da sua leitura sobre Marx. Tomarei aqui apenas dois faros para seguir com minha contribuição para essa discussão. O primeiro faro diz respeito à formulação mais geral de Derrida, que afirma "é preciso ler Marx para além do marxismo"; ler Marx como um pensador que não se encerra na clausura do marxismo. Esse pensamento, porém, não se coloca contra o marxismo. Ao contrário, é somente participando de uma certa herança do que Marx e o marxismo foram capazes de partilhar que ainda podemos continuar pensando Marx como um movimento sempre por vir, como uma tarefa de necessidade e de falta irremediável: Marx por vir! - diria Derrida. Dizendo sim a esse faro, partirei, então, para o segundo: o uso da palavra dança por Derrida (1994) e por Marx (2013). Os dois faros são suplementares, pois ecoam no sim, sim da abertura da leitura de Marx e de Derrida, para além do marxismo e para além de um derridianismo (se é que podemos afirmar que há no espectro de Derrida alguma coisa formulada como tal). Disse antes "uso da palavra dança" para marcar, de partida, uma questão crucial que nos ajudará a pensar a discussão do que estou chamando de fator econômico circular com a dança, a partir de minha leitura de Espectros de Marx. Ambos, Marx e Derrida, usam a dança - o que isso quer dizer? Pensarei a seguir como um faro, repito, na sua fé sem garantias.

${ }^{250}$ DERRIDA, 1994, p. 21.

${ }^{251}$ DERRIDA, 1994, p.-? 
Precisarei incorporar um largo parágrafo ${ }^{252}$ de Espectros de Marx para iniciar o debate, sem aqui prometer um estudo clínico desse texto tão especulado na trajetória de Derrida. O retorno a essa citação almeja convocar uma ambientação e ao mesmo tempo adjudicar uma dívida, fazer justiça a essa memória que vem antes de tudo como uma atração - porque preciso reconhecer que, se falei tanto de espectros nesta tese, foi por uma relação de prazer da incorporação. Vou pedir licença, mais uma vez, para exercitar um pouco desse disparate, dessa conjunção de forças já incorporadas, como se fossem minhas, por tantas repetições, sem jamais as possuir. Acompanhemos Derrida:

Se me apresto a falar longamente de fantasmas, de heranças e de gerações, de gerações de fantasmas, ou seja, de certos outros que não estão presentes nem presentemente vivos, nem para nós, nem em nós, nem fora de nós, é em nome da justiça. Da justiça onde ela ainda não está, ainda não está presente, e aí onde ela nunca será, não mais do que a lei, redutível ao direito. É preciso falar do fantasma, até mesmo ao fantasma e com ele, uma vez que nenhuma ética, nenhuma política, revolucionária ou não, parece possível, pensável e justa sem reconhecer em seu princípio o respeito por esses outros que não estão mais ou por esses outros que ainda não estão aí, presentemente vivos, quer já estejam mortos, quer ainda não tenham nascido. Justiça alguma - não digamos lei alguma, e mais uma vez lembro que não falamos aqui do direito - parece possível ou pensável sem o princípio de alguma responsabilidade, para além de todo presente vivo, nisto que desajunta o presente vivo, diante dos fantasmas daqueles que já estão mortos ou ainda não nasceram, vítimas ou não das guerras, das violências políticas ou outras, dos extermínios nacionalistas, racistas, colonialistas, sexistas ou outros, das opressões do imperialismo capitalista ou de todas as formas do totalitarismo. Sem essa não contemporaneidade a si do presente vivo, sem isto que secretamente o desajusta, sem essa responsabilidade e respeito pela justiça com relação a esses que não estão presentes, que não estão mais ou ainda não estão presentes e vivos, que sentido teria formular-se a pergunta “onde?”, “onde amanhã?" (“whither?”) 253.

Fazer justiça que não é a do direito, nos diz Derrida, com o princípio de "responsabilidade para além de todo o presente vivo". Eis uma convocação a se pensar o estar-com da democracia por vir, fazer justiça à temporalidade disjuntiva, na vinda de outro tempo, de outro estado de dívida: não somente em

\footnotetext{
${ }^{252}$ De tempos em tempos, ao longo desta escrita em que incorporei muitas citações, sempre me deparei com o problema da justiça do corte. Qual a justa medida de uma citação? Quanto devo editar de uma citação?

${ }^{253}$ DERRIDA, 1994, p. 12-13. [Os grifos são de Derrida].
} 
respeito àqueles presentes, vivos, como também àqueles que já não mais estão aqui e aos que ainda estão por vir - a um só tempo, de uma vez por todas. Falar de espectros, com Derrida, reserva essa não contemporaneidade, este segredo do estar junto sem fazer parte, de estar num mesmo tempo quando já se escapa, e estar sempre em débito com a temporalidade e com a alteridade do rastro, do só poder falar da experiência, do se sentir em casa no tempo presente, já incorporando muitos tempos.

Uma política de memória, ele nos diz, é sempre precedida de tal responsabilidade do out of joint do tempo, assim como do pensamento de uma futuridade da ética. A que se busca fazer justiça, afinal? Que seria digno de justiça, de memória, de ser guardado na memória? Que políticas construímos neste estado de dívida? - seriam algumas primeiras perguntas a se fazer com essa passagem de Derrida. Sem jamais poder dar conta de todas elas, por sempre faltar tempo para todas elas, por ora gostaria de dar um giro para pensar como a questão da espectralidade pode ser aprendida como experiência de dança, devido a um certo desajuste comum daquilo que se chama de presença, presentificação ou dação de uma dança e de um espectro; suas relações com o tempo, a memória e a matéria.

Essa aparente aprendizagem com a experiência da dança de forma nenhuma responde a aporética de Derrida do aprender a viver — não se entendemos a resposta que se oferece ao outro como um encerramento de debate, mas talvez seja uma responsividade ao problema de se aprender a viver ${ }^{254}$. Não se quer dizer, portanto, que a experiência de dança dá uma lição sobre tal aprendizagem. Não se trata de uma questão de lição nem de bom exemplo. Não é sobre esse argumento que quero atravessar, propor uma travessia entre dança e espectralidade.

Quero pensar a atração mútua entre tempo do espectro e tempo da dança, da forma/materialidade do espectro e da forma/materialidade da dança que ecoa nos mais diversos textos, não somente nos estudos de dança e performance ${ }^{255}$.

\footnotetext{
${ }^{254}$ Estou me referindo à abertura do exórdio de Espectros de Marx, onde Derrida desenha uma cena aporética: "Alguém, vocês ou eu, se adianta e diz: eu queria aprender a viver enfim. Mas por que enfim? Aprender a viver. Estranha palavra de ordem: Quem pode dar lição? A quem? Que isto sirva de lição, mas a quem? Servirá, alguma vez? Saber-se-á alguma vez viver e, primeiramente, o que quer dizer 'aprender a viver'? E por que ‘enfim'?” (DERRIDA, 1994, p. 9).

${ }^{255}$ Há um pungente debate nos estudos da performance e nos estudos de dança, sobretudo nos Estados Unidos, sobre o problema da documentação e das políticas de arquivo das chamadas artes
} 
Essa atração está também num certo Marx de Derrida que toma a dança para descrever o caráter místico e movediço da forma-mercadoria, seu "fetichismo"; a dança que se dá-a-pensar em Marx (em seu rastro remissivo em Derrida) a partir do movimento de uma Coisa-mesa, que na sua qualidade "sensível suprassensível” gira, saindo de si, "deslocando-se livremente, por sua própria vontade, com um movimento da cabeça, mas que comanda todo o seu corpo, dos pés à cabeça, lígnea e desmaterializada - a Coisa-mesa parece estar no princípio, no começo e no comando dela mesma" 256 .

Que telecoreografia mais paradoxal: a saída de si da matéria que se torna Coisa livre - que Derrida escreve em maiúsculo para rasurar o sentido de coisa autônoma, sendo desde já uma Coisa sem ser-coisa —, ainda madeira, matéria lígnea, porém desmaterializada na sua dança. Esclarece Marx:

Por exemplo, a madeira continua sendo madeira, uma coisa sensível e banal ["prosaica" é a palavra usada na tradução de Espectros de Marx para o português]. Mas, tão logo aparece como mercadoria, ela se transforma numa coisa suprassensível. Ela não se contenta em manter os pés no chão, mas se põe de cabeça para baixo em relação a todas as outras mercadorias, e em sua cabeça de madeira nascem minhocas que nos assombram muito mais do que se ela começasse a dançar por vontade própria. $\mathrm{O}$ caráter místico da mercadoria não resulta, portanto, de seu valor de uso ${ }^{257}$.

Quando Marx diz que "o caráter misterioso da mercadoria não resulta, portanto, de seu valor de uso", ele está se referindo à sua premissa de que a noção de valor se dá, a partir de sua grandeza e de sua quantidade material, em relação e

da presença, artes do corpo, também das chamadas artes cênicas ou ainda das mais variadas formas de dança, teatro, performance art, fotografia - entre tantas maneiras de se agrupar a experiência que se chama arte arquivadas na noção de arte. Mais radicalmente, os estudos da performance têm pensado as questões de evento/acontecimento para além do campo artístico restrito, como nas outras práticas corporificadas de representação, performatividade e iterabilidade. Algumas teorizações nesse campo têm inclusive tensionado seus estudos junto às contribuições de Jacques Derrida sobre os mais diversos temas, como a espectralidade, o mal de arquivo, a questão do rastro, da diffèrrance, entre outros. Farei uma contribuição para esse debate mais adiante, ainda nessa seção.

${ }^{256}$ DERRIDA, 1994, p. 204.

${ }^{257}$ MARX, 2013, p. 146, grifos meus. [O trecho citado na tradução de Espectros de Marx (1994) difere da tradução de $O$ Capital (2013) que estou adotando nesta tese. Cito-a aqui: "Modifica, por exemplo, a forma da madeira, quando dela se faz uma mesa. Não obstante a mesa ainda é madeira, coisa prosaica, material. Mas, logo que se revela mercadoria, transforma-se em algo ao mesmo tempo perceptível e impalpável. Além de estar com os pés no chão, firma sua posição perante as outras mercadorias e expande as ideias fixas de sua cabeça de madeira, fenômeno ainda mais fantasmático do que se dançasse por iniciativa própria. O caráter misterioso da mercadoria não provém de seu valor de uso" (MARX apud DERRIDA, 1994, p. 203-204, grifos meus).] 
em proporção ao acúmulo de trabalho humano, ou melhor, da força de trabalho humano que na mercadoria se cristaliza por complexo processo de troca. Ou seja, os valores são produtos do trabalho humano que já "se transformou em nossas mãos" ${ }^{258}$. Diferentemente do objeto prosaico (mercadoria de uso), a forma mercadoria fetichista é dotada, abstratamente, de propriedades humanas (tem cabeças e pés), e as minhocas que nela surgem nos assombrariam mais fantasmaticamente "do que se dançasse por iniciativa própria". Ou seja, Marx já está dizendo que, se nessa transformação da mesa em mercadoria fetichista ela começasse a dançar, não nos assombraríamos tanto quanto assistindo às "minhocas" que brotam de sua cabeça. A mesa-mercadoria é portanto uma mesa que pode dançar fantasmaticamente. Há mesas que já dançam, como o filósofo adverte em nota ${ }^{259}$.

Sobre essa associação fantasmática entre dança e a forma-mercadoria fetichista de Marx e sua Coisa-mesa, Derrida escreve:

[A mesa] entra em transes ou em levitações, parece aliviada de seu corpo [notemos aqui esse peso de ancoragem que se vê livre, aliviado], como todos os fantasmas, um pouco louca e desregulada também, "out of joint", delirante, caprichosa, imprevisível. Ela parece dar espontaneamente seu movimento, mas dá também movimento aos outros, sim, põe tudo em movimento à sua volta, como "para incentivar (encourager) os

\footnotetext{
${ }^{258}$ Notemos essa transformação abstrata e também telecoreográfica do trabalho "como nossas mãos", ou seja, o trabalho como nosso próprio corpo na era do capitalismo, em que tudo se torna mercadoria. A passagem de Marx diz: "Abstraindo do valor de uso dos corpos-mercadorias, resta nelas uma única propriedade: a de serem produtos do trabalho. Mas mesmo o produto do trabalho já se transformou em nossas próprias mãos. Se abstrairmos de seu valor de uso, abstraímos também os componentes [Bestandteilen] e formas corpóreas que fazem dele um valor de uso. [Essa premissa será fundamental para o pensamento de Marx sobre a questão do espectro como forma corpórea desmaterializada]" (MARX, 2013, p. 116). Mais adiante, o filósofo alemão também diz: “Assim, um valor de uso ou um bem só possui valor porque nele está objetivado ou materializado trabalho humano abstrato. Mas como medir a grandeza de seu valor? Por meio da quantidade de 'substância formadora de valor', isto é, da quantidade de trabalho nele contida. A própria quantidade de trabalho é medida por seu tempo de duração, e o tempo de trabalho possui, por sua vez, seu padrão de medida em frações determinadas de tempo, como hora, dia etc. (...) O valor de uma mercadoria está para o valor de qualquer outra mercadoria assim como o tempo de trabalho necessário para produção de uma está para o tempo de trabalho necessário para a produção de outra. 'Como valores, todas as mercadorias são apenas medidas determinadas para o tempo de trabalho cristalizado"” (MARX, 2013, pp. 116-117).

${ }^{259}$ Diz a nota seguidamente citada: "Vale lembrar que a China e as mesas começaram a dançar quando todo o resto do mundo ainda parecia imóvel - pour encourager les autres [para encorajar os outros] [Voltaire, Cândido, ou otimismo, c. 19 (N.T.)]. Após as revoluções de 1848, a Europa entrou num período de reação política. Enquanto nos círculos aristocráticos e burgueses europeus surgiu um entusiasmo pelo espiritismo, particularmente por práticas com o 'tabuleiro Ouija', na China desenvolveu-se um poderoso movimento antifeudal, especialmente entre os camponeses, que ficou conhecido como Rebelião Taiping. (N. E. A. MEGA)]" (MARX, 2013, p. 146).

${ }^{259}$ Idem., v. especialmente nota 2.
} 
outros", esclarece Marx, em francês, em uma nota sobre essa dança fantasma: "Quando o mundo parecia estar tranquilo, recorde-se, a China e as mesas começaram a bailar, pour encourager les autres" 260 .

A que associação mais fantástica recorrem Derrida e Marx: dança e fantasma! Que comum partilham essas incorporações? Adverte Marx em nota: quando tudo parecer estar tranquilo, "recorde-se, a China e as mesas começaram a bailar, pour encoutager les autres". Derrida lembra, numa nota de rodapé, que essa advertência era também acompanhada de uma nota em tom de esclarecimento, em que Marx restituía a sua passagem à concomitância da voga espiritualista que ascendia na Europa e da Revolução Taiping na China (fantasmas próprios de sua época). No entanto, Derrida não quer deixar de notar a potência "vaga" e "mediúnica" suplementar ao materialismo de Marx, que o reinscreveria numa "sequência espectrológica muito mais ampla", diz Derrida ${ }^{261}$, fazendo Marx se entregar radicalmente ao tempo da dança.

Ora, o que podemos dizer sobre essa aproximação entre a potência espectral de valor da forma mercadoria (que é a materialidade medida pela força de trabalho do socius em processos de troca) e o dançar não de um sujeito, mas, sim, uma Coisa, sem ser-coisa, material e ao mesmo tempo desmaterializada? Por que Derrida, para falar da fantasmalização da relação social, se apega ao uso da dança de Marx? O que tal dança nos diria sobre a passagem da forma mercadoria de uso, da sua forma prosaica ("natural" e "simplista", para usar termos do filósofo alemão ${ }^{262}$ ) para a entrada da cena espectral no caráter fetichista da mercadoria em Marx?

Para entender essa discussão, de partida notemos que Marx define a forma de trabalho do valor de uso da mercadoria como de caráter simplista, "sem mistério", momentos antes de falar da dança-fantasma da mercadoria. Para Marx, a forma "mercadoria" (da mesa que dança) demanda um trabalho mais complexo que a "mercadoria de uso" (mesa prosaica):

Uma mercadoria aparenta ser, à primeira vista, uma coisa óbvia, trivial. Mas sua análise a revela como uma coisa muito intricada, plena de sutilezas metafisicas e caprichos

\footnotetext{
${ }^{260}$ DERRIDA, 1994, p. 204. [Comentários meus].

${ }^{261}$ Idem., v. especialmente nota 2.

${ }^{262}$ Cf. MARX, 2013, notadamente em: p. 124, p. 133 e p. 146.
} 
teológicos $^{263}$. Quando é valor de uso, nela não há nada de misterioso, seja do ponto de vista de que ela satisfaz necessidades humanas [notemos a reiteração de satisfação humana como "natural ao homem", na visão de Marx] por meio de suas propriedades, seja do ponto de vista de que ela só recebe essas propriedades como produto do trabalho humano. É evidente que o homem, por meio de sua atividade, altera as formas das matérias naturais de um modo que lhe é útil. Por exemplo, a forma madeira é alterada como uma coisa sensível e banal [prosaico]. Mas, tão logo aparece como mercadoria, ela se transforma numa coisa sensível-suprassensível $(. . .)^{264}$.

Derrida irá questionar o sentido de material prosaico aplicado por Marx e sua aproximação com a ideia de pureza natural de uma mercadoria de valor de uso de trabalho "sem mistério" e, portanto, já própria às necessidades humanas. Nesses termos, a mercadoria de valor de uso de Marx se mantém como se estivesse afastada do processo de circulação da mesa, como se dissesse que há um estágio anterior da mesa que ainda não começou a dançar. No entanto, para Derrida, esse mesmo valor de uso do prosaico se estabelece — "firma os seus pés no chão", para usar a alegoria de Marx - ao menos prometendo-se “à iterabilidade, à substituição, à troca, ao valor" ${ }^{265}$, já circulando não somente numa economia de repetição e de transportes da materialidade da madeira, como também na economia de signos sem a qual não poderíamos identificar "mesas" nem mesmo fazer "mesas" se inscreverem no mundo como "mesas-prosaicas". Há um transporte iterativo muito complexo que se produz no valor de uso de "mesa, mesa, mesas...", diria Derrida.

O filósofo franco-argelino, assim, quer marcar a questão do rastro que impossibilita o uso de qualquer noção no sistema econômico como "puramente prosaico", lembrando que "não há nenhum valor de uso que a possibilidade da troca e do comércio (...) não (se) inscreva antecipadamente em um fora-de-uso significação extravasante que não se reduz ao inútil"266. Em outras palavras, a mesa antes de entrar em cena como mercadoria já ronda e vaga numa arquiescritura e numa certa circularidade ${ }^{267}$, configurando um outro socius

\footnotetext{
${ }^{263}$ Grifo essa passagem por razões que se esclarecerão mais adiante.

${ }^{264}$ MARX, 2013, p. 146.

${ }^{265}$ DERRIDA, 1994, p. 213.

${ }^{266}$ Ibid., pp. 213-214.

${ }^{267}$ A questão do círculo em Derrida é ponte para pensar um fator econômico narrativo mais radical que abre portas para outros pensamentos de economia. Diz Derrida, em Given Time: "O círculo está no centro de qualquer problemática de oikonomia, como faz qualquer campo econômico:
} 
anterior ao ser-simplesmente-valor-de-uso-dado-às-necessidades-do-homem, como pensado por Marx. O valor de uso da mesa - a força de sua significação, que permite Marx inquiri-la como valor de coisa prosaica - é vago (como um fantasma) antes mesmo de ser mercadoria [e não há nenhuma metafísica ou teologia que nos socorra dessa operação]. A mesa atua e circula num certo regime de trabalho de valor entre rastros, no endividamento irremediável do rastro significante. Tal economia se dá, também, agenciada pelas mãos laboriosas de um filósofo sobre a sua mesa escrevendo as noções que lhe satisfazem, naturalmente como hipóteses, como no caso de um Marx que se satisfaz com o uso de mesa entre forma prosaica e forma fetichista.

Derrida, assim, irá falar de uma dança ainda mais radical que não começou a dançar na alegoria de Marx. Para Derrida, o dançar da Coisa-mesa, da forma-mercadoria de Marx, "paralisa" ou, ao menos, "mecaniza" a dança - e essa mecanização já está marcada, diria, desde o domínio das partes entre cabeça e corpo. Na telecoreografia de Marx, a mesa tem a cabeça como guia - e aqui caberia se perguntar: por que marcar essa antropomorfização tão peculiar da mesa para falar de dança? Poderia Marx falar de danças de seres vivos que não têm cabeça ou que não têm pés; ou danças de seres vivos que não têm a cabeça afastada do chão (como as próprias minhocas). A escolha de Marx, me parece, não é casual. Ela está dentro de um mundo de possibilidades, no horizonte do filósofo alemão diante de sua mesa.

Derrida irá dizer que Marx fala de dança (da graça prometida de uma mesa na sua forma fetichista e espectral do poder dançar), mas não está radicalmente entregue à dança. Vejamos a passagem:

\begin{abstract}
O mesmo se diria, aliás, se enveredássemos (...) para o valor de troca: ele está igualmente inscrito e extravasado por uma promessa do dom para além da troca. De uma certa maneira, o equivalente-mercadoria paralisa ou mecaniza a dança que ela parecia iniciar. É para além do valor mesmo, do uso ou da troca, da técnica e do mercado, que a graça é prometida, quando não dada, mas, de modo nenhum, entregue à dança [e, por favor,
\end{abstract}

intercâmbio circular, circulação de bens, produtos, signos monetários ou mercadorias, amortização de custos, receitas, substituição de valor de uso e valor de troca. Esse motivo de circulação pode nos conduzir a pensar que a lei da economia é o - circular - retorno ao ponto de partida, à origem, também a casa. Assim teríamos que seguir a estrutura-odisseia [odyssean structure] da economia narrativa" (DERRIDA, 1992, p. 6). Essa noção de fator econômico pensado por Derrida irá encetar uma discussão importante sobre a questão da herança do arquivo e sua implicação ético-política, a qual discutiremos a seguir. 
notemos aqui, o grifo é de Derrida]. Sem desaparecer, o valor de uso torna-se, desde então, uma espécie de limite, o correlato de um conceito-limite, de um começo puro a que nenhum objeto não pode nem deve corresponder e que é preciso, portanto, complicar em uma teoria geral (mais geral em todo caso) do capital. [...] Se ele mesmo conserva algum valor de uso (a saber, o de permitir orientar uma análise do processo "fantasmagórico", a partir de uma origem fictícia ou ideal, portanto já purificada por um certo fantástico), esse conceitolimite do valor de uso se encontra de antemão contaminado, isto é, pré-ocupado, habitado, obsidiado pelo seu outro, a saber, este que nascerá na cabeça de madeira da mesa, a forma-mercadoria e sua dança de fantasma. ${ }^{268}$

A teoria da forma-mercadoria de Marx entra em cena como um espectro que dança, animada pela dança como uma graça, mas jamais entregue à dança, nos diz Derrida. A racionalidade analítica a que se dedica Marx - pelo trabalho de suas mãos de filósofo - toma a dança como suplemento de sua fantasmagoria, mas jamais conduzido pela dança, jamais sem perder a cabeça. Essa dança controlada é também um conceito-limite da forma de se pensar os processos de troca e comércio reinscritos na textualidade social ${ }^{269}$. Na economia semiótica de Marx, desde a definição de movimento da dança pela cabeça, há um controle de forças, sobretudo da força fraca do rastro que, se levada a sério, constituiria uma impossibilidade irredutível de orientação. A essa força desestabilizadora sem soberania, que em outro lugar Derrida chamou de "atopia ou loucura da dança que pode comprometer as hipóteses políticas" ${ }^{270}$, a telecoreografia de Marx ${ }^{271}$ não se entrega.

\footnotetext{
${ }^{268}$ Ibid, p. 214. [Os grifos são de Derrida].

${ }^{269} \mathrm{Na}$ segunda seção desta tese, falei dessa relação entre pé e cabeça de um texto, além dos valores de importância entre título (acima), suplemento, epígrafe, rodapé. Derrida, em Mal de Arquivo (2001), comenta a noção de exergo num texto, que consiste em "capitalizar numa elipse. Acumular de antemão um capital e preparar a mais-valia de um arquivo. Um exergo estoca por antecipação e pré-arquiva um léxico que, a partir daí, deverá fazer lei e dar a ordem contentando-se em nomear o problema, isto é, o tema" (DERRIDA, 2001a, p. 17). Essa outra economia política do texto cortado em partes e em valores distintos não pode ser desconsiderada dentro da noção de fator econômico pensado por Derrida.

${ }^{270}$ DERRIDA, 1992, p. 100.

${ }^{271}$ Reiteradamente chamo a cena de Marx de uma telecoreografia para marcar nela o que vimos discutindo sobre esse termo, que porta a distância já incorporada no radical tele. Marx fala de mesas anunciando que há aquelas que dançam e outras que ainda não começaram a dançar, mas que igualmente poderiam fazê-lo sem que nos assombrássemos tanto quanto nos assombraríamos com as minhocas que saem de sua cabeça. Marx desenha todos esses movimentos em espaçostempos distantes. Sua teoria se inscreve tele-coreografando mesas. De certa maneira, criamos um paradoxo em relação ao pensamento de Derrida (ou melhor, com Derrida para além de Derrida). Se dizemos sim, sim à noção de telecoreografia, podemos dizer que Marx já está entregue radicalmente aos rodopios de uma certa dança.
} 
Na sua desconstrução da mesa fantasmática de Marx, Derrida abre uma brecha para pensarmos, outra vez, a força fraca de um rastro econômico perturbador dos processos de formação do social, considerando a dança para além da forma de imagem, alegoria ou metáfora da política e do social: a dança pensada na economia derridiana. A telecoreografia de espectros, com Derrida, torna-se um estado de promessa, ora seguido e perseguido por um desejo de orientação, ora acionada na sua performance já entregue à força fraca de seu rastro.

Em um outro texto, Chorégraphies (1992) ${ }^{272}$, Derrida nos dá outra pista para ponderar a radicalidade desse pensamento:

\begin{abstract}
A grande dificuldade é a necessidade de entregar a dança, o tempo da dança, à "revolução". A atopia ou loucura da dança [l'atopie ou la folie de la danse] de certa maneira também pode comprometer as hipóteses políticas e servir como um álibi para abandonar as lutas "feministas" organizadas, pacientes, laboriosas, em contato com toda a resistência que um movimento de dança não pode dar, embora dança não seja sinônimo nem de impotência nem de fragilidade ${ }^{273}$.
\end{abstract}

Mais adiante, explicarei como a questão das "lutas 'feministas' organizadas, pacientes, laboriosas" chegam a essa passagem de Derrida. Por ora, preciso chamar atenção a essa outra revolução do tempo da dança, sua economia e singular de atopia. Notemos a contradição que pode haver entre a aproximação da noção de força fraca e a de revolução do tempo da dança. A força fraca do rastro a que me referi acima tampouco é "sinônimo de fraqueza e fragilidade".

Para entender essa noção, é preciso retomar o pensamento do rastro: o apagamento de si, da circularidade de um si como obliteração irremediável - e sem nostalgia ${ }^{274}$ — da experiência de inscrição de um rastro como uma dança, pode perturbar uma certa arquieconomia de estabelecimento e atribuição de um signo, objeto ou coisa. Estou falando de uma noção de fugitividade da dança no seu dar-a-pensar sem horizonte ${ }^{275}$. Tal fugitividade resistiria à semântica fenomenológica que retoma a necessidade da noção de objeto, a necessidade de um estrito senso de se tratar uma alteridade como um objeto desde a

\footnotetext{
${ }^{272}$ IN: DERRIDA, J. Points de Suspension. Paris: Editions Galilée, 1992.

${ }^{273}$ DERRIDA, 1992, p. 100.

${ }^{274}$ SPIVAK, 1997.

${ }^{275}$ Articulei essa questão anteriormente como uma impossibilidade do direito-direto à dança e à filosofia. Agora a reencenarei de uma outra maneira.
} 
ficcionalização do diante da mesa de um filósofo. Quero afirmar que dança, a partir das telecoreografias que pensamos até então, não é um objeto (nem mesmo é uma coisa, um ser ou um sujeito). Danças, na economia radical de seus rastros, não podem ser pensadas como materialidades prosaicas naturalmente disponíveis ao equipamento visual. Essa afirmação tem implicações muito sérias no fator econômico que falamos a respeito do pensamento de Derrida. Vamos por partes.

Sara Ahmed, em seu artigo Orientations Matter (2010) ${ }^{276}$, nos oferece uma leitura interessante sobre a alegoria da mesa recorrente tanto no pensamento da fenomenologia de Husserl, notadamente na sua obra Ideias para uma Fenomenologia Pura e para uma Filosofia Fenomenológica (1913), quanto na materialidade de Marx, em o Capital (1867). O pensamento de Ahmed sobre a questão da mesa entre fenomenologia e marxismo toma uma rota diferente da que viemos traçando até aqui, sobretudo porque ela escolhe não pensar a dança que é citada por Marx. Porém, telegraficamente, irei destacar algumas passagens de Ahmed que nos ajudarão a perscrutar as razões de tal obliteração da dança e o problema do objetal como horizonte.

Logo no início de seu artigo, Ahmed esclarece:

Por que mesas? Mesas materializam/importam ${ }^{277}$, você poderia dizer, como objetos adiante sobre os quais fazemos coisas. Poderíamos descrever a mesa como um "sobre" o dispositivo; a mesa fornece uma superfície sobre a qual damos lugares as coisas, bem como fazemos as coisas. Se fazemos as coisas sobre as mesas, então as mesas são efeitos do que fazemos ${ }^{278}$.

Mais adiante, refletindo sobre a escolha de Husserl pela mesa, a autora também nos diz: “As mesas estão 'quase à mão', juntamente com o mobiliário como cadeiras que fixam o 'lugar' comum da filosofia. O uso de mesas nos mostra a própria orientação da filosofia na mão, mostrando-nos o que é próximo

\footnotetext{
${ }^{276}$ In: COOLE and FROST (ed.). New Materialism: ontology, agency and politics. Durham \& London: Duke University Press, 2010, pp. 233-257. [Tradução minha.]

${ }^{277}$ Adotei essa tradução tentando jogar com o duplo que a palavra matter performa em inglês. Poderíamos também dizer "pesam/importam".

${ }^{278}$ AHMED, 2010, p. 235.
} 
ao corpo do filósofo ou o que o filósofo entra em contato com"279. A mesa encena uma prótese bipartida na orientação da tarefa de um filósofo: estar-se sobre ela ao mesmo tempo que se depara diante dela como objeto de estudo. Ela está sempre lá, à disposição, é a base que sustenta qualquer hipótese (sobretudo quando construímos hipóteses de que as mesas repousam lá, em algum lugar, como valor de uso antes de começar a dançar).

A familiaridade com o objeto mesa é também problematizada por Derrida, em Espectros de Marx, como "muito familiar", a quem Ahmed responde:

Não é surpreendente que Jacques Derrida faça uma crítica da distinção marxista entre o valor de uso e valor de troca, girando em direção à mesa. Ele sugere: "A mesa é familiar, muito familiar". Para Derrida, a mesa não é simplesmente algo que usamos: "A mesa tem sido desgastada, explorada, sobreexplorada, ou ainda além e fora de si, não somente no uso de lojas de antiguidades ou salões de leilões". Ele, portanto, sugere que "a mesa em uso" é tão metafísica como a "mesa como mercadoria" 280 : o valor de uso, bem como o valor de troca, envolve fetichismo. Embora concordemos com esse argumento, poderíamos observar que, para Marx, a mesa em uso não é simplesmente inerte ou uma questão de matéria: ela envolve a "trans-formação" da matéria em forma. O valor-uso não é, portanto, uma questão simples de matéria para Marx, mesmo que ele localize o transcendental na mercadoria. ${ }^{281}$

A resposta de Ahmed a Derrida oblitera a questão da dança e do uso da dança na alegoria marxista e seu deslocamento feito em Espectros de Marx (1994). É justamente nessa obliteração que pode delirar [e, por favor, quero marcar o uso de delírio aqui sob rasura $]^{282}$ : para Ahmed, Derrida teria esquecido a

\footnotetext{
${ }^{279}$ Idem., p. 237.

${ }^{280}$ Essa é uma suposição de Ahmed e não de Derrida. Afirmar que mesas, como qualquer alteridade, estão sempre "dançando", no sentido de que nunca repousam como objetos "naturais", não quer dizer que elas são metafísicas.

${ }^{281}$ Idem., p. 242.

${ }^{282} \mathrm{Eu}$ já pensei em outro lugar a questão da loucura e do estar fora de si junto ao subjétil (DERRIDA, 1998), que não marca nenhuma interpelação injuriosa. O estar fora de si é pensado como uma força errante de uma subjetilidade, uma "tomada de decisão sem rumo acertado, como um sonho jamais premeditado, demência não alienada, ou uma sensatez diferente em que não se busca nem o fim nem a certeza" [ANDRADE, 2013a, p. 88]. Especificamente, aqui, delírio sob rasura faz uma remitência a la folie [loucura] tida por Derrida como o tempo da dança, "a revolução" do pensamento, que proponho pensar como o seguir dançando do rastro iterativo. Aquilo que se experimenta com a ocorrência de uma dança como rastro ou da experiência do rastro como uma dança. Pensamento que segue, circula, vagueia e que se tem como uma reunião somente na memória, nas reiterações de memória, já numa certa economia de memória, em outras palavras, "telecoreografando memórias". Estou propondo, sob rasura, tal delírio dançante como o
} 
trans-formação da matéria em forma. Porém o delírio de Derrida vai mais além. Ele nos diz que a trans-formação da matéria em forma de Marx se dá pelo uso e pela iterabilidade vaga desse uso desde o nascimento; uma dança mais radical à qual o valor de uso de Marx não pode se entregar e com a qual não pode também dançar, pois precisa se manter na ficção de uma mesa dada/prosaica - que é também o chão onde se fixa a hipótese de Marx. Seguindo esses múltiplos delírios, agora meus também, eu acrescentaria mais um: essa radicalidade de uma dança que vagueia cria um problema para a pressuposição de uma disposição sempre "diante de" aquando da relação que se tem com uma alteridade.

Marx, mesmo sem desejar [talvez], está fora-de-si quando usa a dança, quando telecoreografa a mesa como um objeto prosaico para definir a sua mercadoria de valor de uso naturalmente à disposição do homem. Derrida, também fora-de-si, reitera a dança de Marx, convocando-o a se entregar radicalmente à dança. Ahmed aceita a dança de Derrida até certo ponto, mas aponta um certo esquecimento da trans-formação da matéria em forma abstendose de seguir o rastro da dança em Marx e Derrida. Minha escrita, em curso, por sua vez, vagueia na iterabilidade dessas múltiplas telecoreografias. A mesa dança/exorbita na experiência de pensamento em desconstrução — ou na experiência de uma revolução do pensamento como uma démarche iterativa. Incorporações e deslocamentos, telecoreografias já numa economia da espectralidade, do estado de dívida que jamais podemos quitar; citações de citações... Essa pode ser, talvez, uma experiência/experimento singular [exorbitante ao apreender] que se dá, sempre localmente, sempre como hipóteses sem horizontes, já na experiência/experimento de um tempo de dança, de um certo tempo quando um pensamento vem dançando.

[É importante marcar uma diferença ou um apelo: esse aprendizado exorbitante ao apreender como tempo de dança não define uma ontologia. Não se faz a defesa de uma ontologia da dança nem mesmo de uma ontologização de Derrida ou Marx com a dança. A dança que se persegue e pela qual se é perseguido, aqui, convoca a pensar uma forma de articulação: "simultaneamente ao que acontece no mundo, por um lado, e, por outro, ao modo de se responder ao que acontece no mundo" - uma recorrência que Paulo Cesar Duque Estrada 
marca como um estilo, senão uma assinatura, da desconstrução de Derrida: "De alguma forma, o seu pensamento [o de Derrida] se articula no 'entre', na junção, desses dois momentos inseparáveis; o do acontecimento e o da resposta ao acontecimento" 283 . Se apelo à fugitividade da dança entre telecoreografias, forço somente uma estratégia, abrindo e esburacando cirurgicamente o chão e as margens em que se trafega nesta tese. Portanto, não falo aqui de todas as danças, tampouco de um princípio para todas as formas de se "pensar-fazer danças", seja em Marx, Derrida ou além. Tal exercício de pensamento segue e persegue espectros assumindo os delírios, os giros, as irredutíveis e não restituíveis telemáticas, as perdas de centralidades e de fundamentos etc.]

Diferentemente de um objeto mesa, a espacialidade de tomada de chão de uma dança está, desde sua inscrição, lançada como um rastro que foge do horizonte. A dança mesmo quando diante de um certo nós performa a fuga do objetal que se dá no horizonte. Já Husserl fecha os olhos diante da mesa e, quando retorna nos diz: "Sob nenhuma circunstância ele [o objeto] voltará para mim individualmente o mesmo. Apenas a mesa é o mesmo, sabida como idêntica através da consciência sintética, que liga a nova experiência com a recordação" 284 . No caso da disposição espacial engendrada pelo rastro fugitivo de uma dança, não se pode facilmente deduzir a mesma hipótese. A cinética da trans-formação da mesa na consciência sofre um abalo pela impossibilidade de retorno à fixação da revolução dançante em marcha que nunca está lá em nenhum lugar, pois ela performa antes uma dação de lugares e uma mudança de lugares.

Aquilo que se guarda na memória, como uma reunião de corpo ou de coreografia, é uma fuga e um assombro da noção de objeto, que não remonta nem pode restituir qualquer noção de origem ou de pureza de origem. Retorna-se, na memória, à experiência dançada tal como um rastro, que para Derrida é uma: “diferença sem sujeito, espécie de significante sem significado, desperdício de um ornamento sem corpo próprio, ausência total de propriedade, de verdade, de senso, um desdobramento apenas de formas que se destroem imediatamente" ${ }^{, 285}$. O rastro que se guarda na memória - a experiência/experimento de dança — está endividado desde a incorporação. A dança que se guarda na memória já é outra,

\footnotetext{
${ }^{283}$ DUQUE-ESTRADA, 2008,p. 13.

${ }^{284}$ HUSSERL, 1913 apud AHMED, 2010, p. 238.

${ }^{285}$ DERRIDA, 2006, p. 266.
} 
incorporada como outra, e está lançada à iterabilidade do poder recordar ante à desaparição. Siga-me, guarde-me, adeus! ${ }^{286}$ - num só tempo, em tempos diferentes: tempo out of joint.

Tal fugitividade nos diz que uma dança nunca se dá num lugar, ela é a ocorrência da dação de lugares que desaparece no próprio ato de dançar. Pensar na sua materialidade como desaparição não afirma o mero desaparecimento de formas da dança - pois a forma é ainda dada, estudada, aferível e, antes de tudo, registrada, experimentada em algum processo de telecoreografia. Quer-se então pensar de maneira mais radical sobre essa incondicionalidade da desaparição, no seu desajuste de tempo-espaço como acontecimento onde o "aí, o ser-aí [l'êtrelà], existe apenas com base nessa obra de rastros [traces] que se desloca"287.

O acontecimento de uma dança se dá numa duração a qual já se está entregue - e aqui eu não estou falando somente de uma estética, do entregar-se à contemplação, ou ainda da percepção diante de uma obra, em que a dança, por vezes, pode ser anunciada como objeto. Falo também da experiência do não ver quando se dança (o bailarino não vê a dança que ele performa plenamente, nem quando diante de um espelho). Há rastros que se demoram, registram impressões e marcam como restâncias da própria memória, do que aparentemente se dá em lugares. Nessa experiência e nesse experimento, há alguma tomada de lugar aí. No entanto, nesse aí, é preciso que desapareça essa outra lei dos deslocamentos de lugares, ainda que por um instante, [ou seja, é preciso que haja desaparição da desaparição] para que se guarde alguma experiência de dança como um experimento de memória telecoreográfica do siga-me, guarde-me, adeus!

Guardam-se na memória rastros do desdobramento de formas que se destroem na sua performance; rastros que se demoram, como aparições. O deslocamento de lugares da dança, no entanto, mostra-se no desaparecimento dessa lei de deslocamento de lugares pela mesma aparição que se dá ou se demora como uma dança na memória. Há sempre alguma experiência de captura, de reunião, de unidade no espaço a que nos referimos como a experiência de uma certo gesto dançante. Uma certa repetição, ou fixação de um certo again, o ir e vir, como de um gesto capturado no piscar de olhos. Formas, poses, notações, passos, assinaturas... a história da dança está repleta de nominalidades para se referir a

\footnotetext{
${ }^{286}$ Peço ao leitor que guarde essa formulação em algum lugar da memória.

${ }^{287}$ DERRIDA, 2012, p. 32.
} 
essa "coisa" que não é uma coisa, mas, sim, uma experiência/experimento da passagem e da demora de uma dança, de algum traço que pode ser rastreado como tal, um rastreamento do fenômeno que aparece como dança.

A lembrança, o retorno de uma aparição, vem nesse arquivo de restos, como alguma demora antes do desaparecimento, como alguma memória que esquece, ainda que por um instante, do deslocamento dançante, do seguir movendo como em ação. É somente nesse lembrar-se de esquecer, no aparecimento que desaparece aquilo que chamamos de experiência/experimento da dança, que podemos dizer que há uma tomada de lugar da dança. Experiência/experimento também de um/a bailarino/a, que para seguir uma coreografia precisa lembrar-se de esquecer, passar de uma posição para outra. Nessa turbulência, senão nesse trauma, do deslocamento de lugares, da impermanência daquele mesmo rastro dançante, podemos falar do aprendizado exorbitante da dança como um sofrimento.

O que se aprende com a dança, do tempo-espaço da dança, sua revolução em pensamento, tem a ver com o duplo tom de sua fugitividade: sofre-se pela sua passagem; somos afetados/golpeados por ela como um rastro que se guarda já sendo incorporado, como uma cicatriz, já dando, ex-corporando, seu corpo. Sofrese também com sua partida, pelo seu trabalho de luto já de partida: da partida da dança e da partida de tempo-espaço que se dá com uma dança, dividindo a múltiplos golpes aquilo que se guarda e que se tem como rastro de presença, do tempo presente, e do estar aí no espaço, que não reinstaura nenhum aí como lugar. Pelo seu trabalho de luto, aprende-se com a dança a impossibilidade de apreendêla como um objeto no horizonte. É preciso perseguir, se demorar, se entregar aos seus delírios. Dançar junto ao passo que se entrega radicalmente à dança. Que jeito insólito de partilha de tempo/espaço! Um estar junto demasiadamente disjuntivo, de partida, somente uma vez e de uma vez por todas. Talvez seja por isso que Derrida recorreu à dança — usou de sua economia desde o nome. Talvez seja nesse rastro que também poderemos fazer justiça às questões tão caras do pensamento sobre a noção de arquivo e a democracia por vir consideradas pela desconstrução. 


\title{
5.1. \\ Turbulência, Divisibilidade e Sofrimento de Partida: do Mal de Arquivo da Dança e da Performance
}

\begin{abstract}
Entre seus predicados e valores semânticos, economia, sem dúvida, inclui o valor de lei (nomos) e de casa (oikos, lugar, propriedade, família, o coração, a clareira dentro de casa). Nomos não significa a lei em geral, mas também a lei da distribuição (nemein), a lei da partilha ou partição [partage], a lei como partição (moira), o dar ou distribuir parte, participação. Outro tipo de tautologia que já implica o econômico no nômico como tal. Na medida em que há lei, há partição: na medida em que há nomia, há economia. Além do valor de lei e casa, de distribuição e partição, economia implica a ideia de câmbio, de circulação, de retorno. A figura do círculo está obviamente no centro, se isso puder ser dito ainda do círculo. O círculo está no centro de qualquer problemática de oikonomia, como faz qualquer campo econômico: intercâmbio circular, circulação de bens, produtos, signos monetários ou mercadorias, amortização de custos, receitas, substituição de valor de uso e valor de troca. Esse motivo de circulação pode nos conduzir a pensar que a lei da economia é o - circular - retorno ao ponto de partida, à origem, também a casa. Assim teríamos que seguir a estrutura-odisseia [odyssean structure] da economia narrativa.
\end{abstract}

J. Derrida, Given Time (1991).

A noção de economia circular com a dança que viemos pensando gira nas telecoreografias exorbitantes deixadas pelas heranças de Derrida, Marx, Arbeau, Lepecki e muitos outros. Pensar tal economia pode, por um lado, nos falar de um singular estar-com, não de uma aprendizagem apreendida para si, de um bom exemplo que se dá numa lição, mas, talvez, de um dar-a-pensar o estar-com ainda quando não pertencendo a nenhum em si, ao mesmo tempo que se guardando, podendo se guardar numa memória, sem ser-lhe próprio nem apropriado. Um estado de dívida radical que responde à alteridade advinda dos processos de incorporação/excorporação de danças.

Por outro lado, a disjunção injuntiva do siga-me, guarde-me, adeus! de um evento de dança convoca-nos a questões da herança e do arquivo - como são 
pensadas pelo próprio campo da dança, desde o solo de trabalho da dança. Esse convite nos faz refletir sobre como artistas e pesquisadores lidam com formas de organização da cena de dança e sua impossibilidade de se presentificar plenamente como tempo presente. Quais cenas por vir podem surgir daí? Imaginemos outras perguntas.

Como a disjunção temporal de uma dança, desde a forma do seu pesar no seu solo, na sua materialidade de inscrição desmaterializada, pode fazer tremer um certo falogocentrismo da economia da herança, da noção de legado, da participação e negociação de um legado, que, por sua vez, configura os circuitos de valor e suportes para objetos, temas, pesquisas no campo da dança? Se a forma de circulação de coreografias guardam uma herança enquanto máquina de teletransportação que está inscrita no âmbito do desejo e na força dos homens de lei ${ }^{288}$, por que ainda seguir/perseguir coreografias ao passo que se considera uma radical fugitividade da dança? Por que pensar-fazer tele-coreografias, escrever sobre elas? Estamos reforçando o privilégio da economia de arquivo? Ao arquivar danças, estamos despotencializando o seu abalo performativo? A força fraca da dança se deixa sofrer de algum mal de arquivo? Ou, pelo contrário, pensar a noção de arquivo na dança provoca algum abalo na economia do arquival, na oikonomia que a noção de arquivo guarda em si?

Essas perguntas demandam demoras distintas, e não conseguiremos resolver todas elas nesta tese. Porém, sem me furtar ao debate, vou partir do acúmulo e da circulação que, acredito (como fé de um faro sem garantias), já construímos até aqui, na reserva que nos ajuda a pensar uma delas. Quero contribuir para a discussão da noção de arquivo na dança a partir da singularidade das questões de tempo-espaço e da turbulência de sua chegada, do pensamento de sua chegada, como espectro: siga-me, guarde-me, adeus. É preciso ponderar se há, efetivamente, algum privilégio na forma singular que se arquiva num instante de um guarde-me que se dá na passagem entre o siga-me e o adeus de uma dança.

A questão do problema de arquivo na dança já engendrou muitos debates. Partimos, estrategicamente, dos ecos de Arbeau e seu manual coreográfico escrito no século XVI. Porém, mais recentemente, discussões acaloradas têm ocorrido no campo dos estudos da performance, que se dedica não somente aos problemas de

\footnotetext{
${ }^{288}$ LEPECKI, 2006.
} 
documentação nas artes da presença, do corpo e da cena, mas também, para além do campo artístico, a outras práticas corporificadas de representação, performatividade e iterabilidade. Poderia reunir esse debate em duas impressões que parecem se repelir, mas que, a meu ver, se arquivam uma na outra.

I - por um lado, a discussão do arquivo na performance aparece a partir do problema da intraduzibilidade da palavra performance, como comenta Diana Taylor em Arquivo e Repertório (2013). Para Taylor, a intraduzibilidade está marcada pelos diferentes atos de transferência indisciplinar do campo que transita entre estudos da linguística, da retórica e da filosofia (quando os espectros de Austin, Derrida e Butler são mais recorrentes nas complexas camadas), da antropologia e da teatralidade (por sua vez, mais assombrados pela herança de Victor Turner e Richard Schechner - este último inaugurou os performance studies como disciplina nos EUA) e pelas múltiplas reiterações da palavra entre os movimento das artes vanguardistas, do artivismo e do situacionismo. De raiz etimológica francesa, parfournir [que Taylor traduz como completar e realizar plenamente, mas também poderia ser traduzida como dar fim] foi traduzida como performance, para o inglês, no século XVI. Por razões linguísticas e históricas, o termo tem uma circulação singular entre os países das três Américas, entre línguas advindas da herança colonial. Taylor faz uma análise bastante criteriosa sobre a circulação do termo performance e da questão da intraduzibilidade, afirmando que:

\footnotetext{
(...) o problema da intraduzibilidade [dos termos performance e estudos da performance] (...) é na verdade positivo, uma pedra no caminho nos lembra que "nós" - seja em nossas várias disciplinas, línguas ou situações geográficas por todas as Américas - não nos compreendemos uns aos outros de modo simples ou não problemático. (...) Essa pedra no caminho constitui um entrave não apenas para os falantes de espanhol e português que se deparam com uma palavra estrangeira, mas também para falantes de inglês que pensavam saber o que significa performance, ${ }^{\text {, }} 8$.
}

Seguindo uma leitura entre história e estudos culturais, e também pensando na herança colonial da rachadura entre fala e escrita que se desdobra no recalque das diversas práticas incorporadas, sobretudo as práticas dos povos indígenas e seus atos singulares transmissivos, Taylor mais adiante irá propor um

${ }^{289}$ TAYLOR, 2013, p. 44. 
método para os estudos da performance a partir de uma fratura que me parece pouco duvidosa de si:

A fratura, a meu ver, não é entre palavra escrita e falada, mas entre o arquivo de materiais supostamente duradouros (isto é, textos, documentos, edifícios, ossos) e o repertório, visto como efêmero, de práticas/conhecimentos incorporados (isto é, língua falada, dança, esportes, ritual) ${ }^{290}$.

Tal proposição só se mantém na crença e na razão da afirmação de que o arquivo não é ou não se dá numa prática incorporada; ou de que o corpo não sofre de algum mal de arquivo. Taylor marca em seu texto a noção de arquivo como restrita a "documentos, mapas, textos literários, cartas, restos arqueológicos, ossos, vídeos, filmes, CDs, todos esses itens suspostamente resistentes à mudança" 291 . Ao repertório, ela reserva a noção de "memória incorporada performances, gestos, oralidade, movimento, dança, canto - em suma, todos aqueles atos geralmente vistos como conhecimento efêmero, não reproduzível”292. Em ambos os casos, porém, ela admite que paira o problema do desaparecimento, marcando como diferença "em tipo e grau” que: "A performance 'ao vivo' nunca pode ser captada ou transmitida por meio de um arquivo" ${ }^{\text {293 }}$. E arremata em seguida:

A memória incorporada está "ao vivo" e excede a capacidade do arquivo de captá-la. Porém isso não significa que a performance - como comportamento ritualizado, formalizado ou reiterativo - desaparece. As performances também replicam a si mesmas por meio de suas próprias estruturas e códigos. Isso significa que o repertório, como o arquivo, é mediado. $\mathrm{O}$ processo de seleção, memorização ou internalização e, finalmente, de transmissão acontece no interior de sistemas específicos de representação (e, por sua vez, auxilia a constituí-los). Formas múltiplas de atos incorporados estão sempre presentes, embora em estado constante de "agoridade". Eles se reconstituem - transmitindo memórias, histórias e valores comuns de um grupo/geração para outro. Os atos incorporados e performatizados geram, gravam e transmitem conhecimento $^{294}$.

\footnotetext{
${ }^{290}$ Idem, p. 48.

${ }^{291}$ Ibid.

${ }^{292}$ Ibid, p. 49.

${ }^{293}$ Idid, p. 50.

${ }^{294}$ Idem, p. 51. [Grifos meus.]
} 
Nessa passagem, Taylor assume que arquivo e repertório guardam/reservam a mediação em si. Porém ainda insiste em dizer que os atos incorporados, "ao vivo", diferentemente do arquivo estão sempre presentes. A diferença parte do pressuposto de que o "ao vivo" é do tempo presente, está em constante estado de "agoridade", enquanto o arquivo não. Somente a performance está exposta à "agoridade" do tempo presente - é o que diz Taylor. Mas, ora, se o "ao vivo", reservado ao repertório, como o arquivo, é também mediado, segundo disse Taylor, como marcar essa reserva da "agoridade" exclusiva à performance? A resposta está também duplamente arquivada nessa passagem: 1 na pressuposição de afirmar que a performance transmite conhecimento, o que, na concepção de Taylor, significa transmissão de valores comuns de um grupo/geração para outro; 2 - no fato de arquivar na noção de performance a reserva exclusiva de agoridade. Falarei mais adiante sobre a consequência desse gesto duplo de positivar uma reserva exclusiva a uma certa forma de performance.

II - quase ao lado está a negatividade anarquívica da performance associada a uma positividade da efemeridade e da desaparição da performance como sua ontologia. Peggy Phelan, em seu ensaio A Ontologia da Performance (1997), escreve:

\begin{abstract}
A única vida da performance dá-se no presente. A performance não pode ser guardada, registrada, documentada ou participar de qualquer outro modo na circulação de representações de representações; no exato momento em que o faz, ela se torna imediatamente uma coisa diferente da performance. (...) O ser da performance, tal como a ontologia da subjetividade que aqui é proposta, atinge-se por via da desaparição ${ }^{295}$.
\end{abstract}

Phelan sugere o anarquivamento da performance, agrupando arquivos de tradições distintas ("ontologia" e "efetividade", "ser" e "fazer", "continental" e “analítica") para pensar a resistência aos sistemas de representação, de controle e de circulação financeira. Escreve, com tom de sentença ou com tom manifesto, mais adiante: "A performance recusa esse sistema de troca e resiste à economia circular que o fundamenta"; "A performance é a tentativa de valorizar aquilo que é não reprodutivo, não metafórico"296; "A promessa que esse tipo de performance propõe é de aprendermos a valorizar o que é perdido, é de aprender não o

\footnotetext{
${ }^{295}$ PHELAN, 1997, p. 171.

${ }^{296}$ Idem, p. 179. [Grifos meus]
} 
significado, mas o valor daquilo que não pode ser nem reproduzido nem visto" ${ }^{\text {297 }}$. Dessa maneira, Phelan se aproxima do sentido de "ao vivo" pensado por Taylor como uma exclusividade das chamadas performances incorporadas. O gesto de Phelan, porém, difere do de Taylor na medida em que usa um tom mais radical sobre a resistência da performance ao vivo à economia do arquival como uma forma de resistência aos processos de acúmulo do capital financeiro que engendram os circuitos artísticos e as instituições de arte. Phelan, então, convoca:

As instituições devem assim inventar não uma economia baseada na preservação, mas uma economia que responda às consequências da desaparição. As instituições de crédito e de empréstimo nos Estados Unidos perderam a confiança dos seus clientes na promessa de segurança. Museus cujas coleções incluem objetos tomados/comprados/obtidos de culturas que agora pedem (e esperam) o seu regresso devem confrontar a herança da sua história apropriativa de forma muito mais sutil e complexa do que aquela que prevalece correntemente. Finalmente, as universidades, cujo domínio é o da reprodução do conhecimento, devem rever o seu empreendimento teórico através do qual o objeto estudado é o reproduzido enquanto propriedade com valor (teórico) ${ }^{298}$.

Porém a convocação de Phelan já está dentro do jogo teórico de especulação e investimento econômico a partir do acúmulo de teorias e de formas teóricas de se partilhar esse acúmulo. Para apelar à promessa de dar valor ao que é perdido e que não pode ser reproduzido, a noção de performance de Phelan precisa performar [reiterar incorporando na agoridade de seu texto] noções de valor, temporalidade, promessa. Sua proposta tem valor teórico e engendra formas de produção nos circuitos artísticos e acadêmicos. Sua performance está marcada na materialização desmaterializada, na cadeia metafórica e disseminativa de seu discurso.

Penso que ambas as proposições, a de Taylor (2013) e a de Phelan (1997), abrem espaços para gestos, gesticulações e gestações dentro dos Estudos da Performance e têm consequências ético-políticas relevantes para o campo. No entanto, a hipótese da exclusividade das forças anarquivista (Phelan) e intraduzível (Taylor) à noção de "performance ao vivo" só se sustenta na negação especulativa de que seus discursos, na inscrição deixada sobre o papel, já não são

\footnotetext{
${ }^{297}$ Ibid. [Grifos meus]

${ }^{298}$ Idem., p. 189.
} 
performances que se reincidem a cada agoridade iterativa. Há uma divisibilidade entre a promessa e a ação que suplicam. Taylor (2013) e Phelan (1997) agem como se quisessem apagar o registro divisível de seus discursos. Como se a corporeidade re-inscritiva e reiterável de movimentos, gestos, danças, esportes e línguas não passassem por processos que se assemelham à necessidade e à falta de economia e da herança, do lugar e da lei onde se guardam as heranças ${ }^{299}$. Como se a herança arquiviolítica fosse apenas restrita a um modo de tradição (da tradição que se atribui à origem da civilização grega) ou somente à violência das instituições ou somente à materialidade da escrita [esquecendo-se da forma espectral que encena qualquer escrita]. Como se não houvesse nas práticas incorporadas a noção de mestre e discípulo. Como se não houvesse nenhuma instância reguladora nessas práticas (como as figuras do juiz, do sacerdote, do líder; ou ainda a gramaticalidade, a inteligibilidade e o desentendimento entre língua e tradução; ou, mais exaustivamente, a psique e a subjetividade calculadora), portanto já violentas, que permitem alguns acessos e negam outros, aceitam determinadas práticas e outras não. Como se lembrança e esquecimento [o siga-me e o adeus], que operam no instante do "ao vivo", não registrassem nenhum guarde-me no momento da inscrição da experiência. Como se a ação de testemunho do performer e do outro (que pode ser a audiência, o público, mas também a ipseidade do performer, da sua ação, de seu retorno a si na subjetividade) não dependesse de nenhuma khora subjetílica. Como se a disjunção injuntiva do tempo fosse uma reserva privilegiada à noção de "ao vivo" [Para quem? Diante de quem? De que vivacidade e modo de vida ao vivo estamos falando? De que nós?] Como se... como se... essas pressuposições já não arquivassem outras repetições de arquivo; como se não estivessem lançadas à iterabilidade.

Mesmo se levássemos adiante o como se de cada uma dessas hipóteses, se as trabalhássemos como possibilidade ético-política anárquica, sem prestar contas a nenhum endereço, a nenhuma relação comunicativa entre as heranças da noção de arquivo, pela liberdade de se pensar-fazer performances ao vivo sem nenhum compromisso, já não reimprimiríamos e deixaríamos marcas a cada como

${ }^{299}$ Tal como pensou Derrida (2001) a respeito da tradição dos arcontes a que já me referi reiteradamente nas seções anteriores. Na fé sem nenhuma garantia de que o leitor guarda rastros dessa discussão, permito-me não retomar essa questão novamente, pela economia que se imprime na agoridade de meu discurso, na performance que meu discurso está encenando agora. 
se como numa técnica de consignação econômica e especulativa sobre a noção de arquivo?

Taylor (2013) e Phelan (1997) estão comprometidas com suas pressuposições, suas hipóteses circulares (ou com a circularidade oikoconômica de suas hipóteses). Em nome da positivação da transmissão de conhecimento pela performance, Taylor se esquece de que esta também transmite atos que não são comuns, não são valores comuns a um grupo/geração. Performances, se atos incorporados, podem transmitir e ser transmitidas sem nada comunicar, sem nada positivar como valor ou como intuição apropriativa de um grupo, de uma geração, de um povo, de uma unidade ou qualquer ipseidade ${ }^{300}$. Phelan, por sua vez, sabe da perda de valores e apela a uma economia da perda, "sem substituição e sem metáfora", sem refletir, na sua Ontologia da Performance, os incondicionais processos de participação na arquieconomia de seu discursos. As reservas suprimidas nestes pensamentos advêm aquando da contradição de se arquivar as noções de "agoridade" e "ao vivo" como exclusividade de um certo tipo de performance, em detrimento de outro.

O Arquivo e o Repertório e A Ontologia da Performance deixam impressões ${ }^{301}$ que são fundantes, constroem fundos, khoras, subjéteis para os estudos da performance que dirigem rotas, gestos, gestações e gesticulações para o campo em que se afundam. Porém compartilham e sofrem de um problema similar e ao mesmo tempo dissimétrico que aqui, elipticamente, poderia formular da seguinte maneira: ambas suprimem a força por vir do arquivo, aquela que Derrida (2001), pensando com os espectros de Freud, chamou de pulsão de morte do arquivo: força destruidora de si pela sua própria repetição. Tal pulsão de morte do arquivo nos diz sobre "o mal", "a febre" e "a paixão" que ele sofre em sua própria reunião como se, a um só tempo [como numa agoridade disjuntiva], já acolhesse a preservação, a insistência e a destruição de si.

\footnotetext{
${ }^{300}$ A telecoreografia do espectro-Carmen que pensamos/encenamos alhures já nos disse algo sobre isso.

${ }^{301}$ Grifo, na restância desse gesto de "deixar impressões", uma das noções de impressão freudiana pensada por Derrida a que já me referi anteriormente, como a impressão no sentido de marca inscrita desde o nascimento, já na participação de uma arquieconomia de "história de textos e dos discursos, a história das ideias ou da cultura, a história da religião e a própria religião, a história das instituições e das ciências, em particular a história deste projeto institucional e científico que se chama psicanálise [para efeitos da nossa discussão, poderíamos substituir por 'projeto institucional e científico que se chama Estudos da Performance']. Sem falar da história da história, a história da historiografia" (DERRIDA, 2001a, p. 45).
} 
A performance resistente, iterativa e anárquica do arquivo, se levada a sério, não pode ser pensada fora de uma certa economia de arquivo. Sim, eu disse performance de arquivo, pois o arquivo também performa, está lançado na sua performance. E, talvez, precisaríamos seguir um pouco mais Derrida para reelaborar o pensamento sobre o arquivo para além de "itens", “objetos" e “instituições" já assumindo que "jamais se renuncia ao arquivo"302. Diria numa missiva: já não podemos nos queixar do arquivo, nos queixar do mal de arquivo, da sua economia cruel, sem arquivar novas impressões sobre o arquivo; já não podemos nos queixar dele sem imprimir (tipografias, traduções, supressões, repressões, recalques) economias de arquivo. Para mim, pensando com Derrida (2001), o que está sempre em jogo é a política do arquivo como res publica, por isso o apelo à democratização das mais variadas formas e técnicas de arquivo que não estão restritas a mídias, papéis e objetos.

Esse problema ético-político está marcado por Derrida na primeira nota de Mal de Arquivo (2001):

Não determinaremos jamais esta questão como uma questão política [do arquivo] entre outras. Ela atravessa a totalidade do campo e na verdade determina, de parte a parte, a política como res publica. Nenhum poder político sem controle do arquivo, para não dizer da memória. A democratização efetiva se mede sempre por este critério essencial: a participação e o acesso ao arquivo, à sua constituição e à sua interpretação ${ }^{303}$.

Paulo Cesar Duque Estrada nos oferece uma pista importante para se pensar essa democratização evocada por Derrida, de uma maneira efetiva, nas suas palavras, lembrando que:

(...) a acessibilidade e liberdade de interpretação do arquivo não é tudo; é preciso também que a própria constituição do arquivo se encontre ela mesma exposta ao exame, à investigação e à problematização. Depreende-se aqui um argumento que aponta para dois momentos no interior de uma dinâmica cuja "lógica" poderia ser descrita do seguinte modo: embora, por um lado, o pensamento habite o arquivo, embora o trabalho de interpretação, discussão, reflexão se desdobre através do arquivo, há, por outro lado, a necessidade de o pensamento se emancipar do próprio arquivo. Preservação e

\footnotetext{
${ }^{302}$ Ecos ao título do artigo de Jamais se Renuncia ao Arquivo (2010), de Paulo Cesar Duque Estrada. [cf. DUQUE-ESTRADA, 2010.]

${ }^{303}$ DERRIDA, 2001a, p. 16.
} 
rompimento com o arquivo mostram-se, nesta dinâmica, como dois momentos inseparáveis um do outro ${ }^{304}$.

Seguindo o rastro desse pensamento duplo de preservação e rompimento, tal como nos disse Duque-Estrada acima, podemos comentar que Taylor e Phelan se queixam, de maneiras distintas, do arquivo já arquivando novas impressões sobre ele, já participando [mesmo que à revelia] da sua democratização, visto que estão diretamente inscritas na sua economia. Estamos todos nos queixando do arquivo, de seu ritmo avassalador e capitalizador, já dentro de um jogo de repetição, já participando de uma certa tática arquivológica: ardendo no mal de arquivo, já excedendo-o. Repetição, consignação e exterioridade são técnicas de arquivo, é o que nos diz Derrida: "Não há arquivo sem um lugar de consignação, sem uma técnica de repetição e sem uma certa exterioridade. Não há arquivo sem exterior ${ }^{305}$. É dessa maneira que se mantém a arquiviolítica em marcha: pela preservação exposta ao seu rompimento.

Porém é preciso dizer que o mal de arquivo é uma violência cruel, mas pela sua própria crueldade não é um mal absoluto. O arquivo sofre de sua pulsão de morte, acolhendo as impressões contra si, já sensível à sua exterioridade; khora autoimune que, ao mesmo tempo, produz e acolhe anticorpos contra a sua própria soberania. Tal pulsão de morte do arquivo é a anarquia que se guarda desde as suas impressões [sejam elas quais forem].

Com Duque Estrada, podemos ainda pensar sobre o mal do princípio arcôntico que nos diz que, sim, há uma "íntima vinculação entre lugar, começo e comando" 306 na noção de arquivo. Este sim nos conduz a pensar "que todo conteúdo arquivado é sempre e já também um local habitado e resguardado por uma autoridade que detém o seu controle"307. Contudo, o princípio arcôntico "não significa apenas que o arquivo era depositado em algum lugar sobre um suporte estável e à disposição de alguma autoridade hermenêutica". Há uma outra abertura do princípio arcôntico, outro sim, que se dá na sua compreensão como poder de consignação. A noção de consignação é importante exatamente para marcar o fator econômico que todo arquivo reserva como forma de partilha, como lugar de

\footnotetext{
${ }^{304}$ DUQUE-ESTRADA, 2010, p. 2.

${ }^{305}$ DERRIDA, 2001a, p. 22. [Grifos de Derrida.]

${ }^{306}$ DUQUE-ESTRADA, 2010, p. 3.

${ }^{307} \mathrm{Idem}$.
} 
depósito e de divisibilidade entre herdeiros e, também, como reunião. E é justamente na consignação do arquivo compreendido como poder de consignação que começa a sua desconstrução, gesto que Derrida pensará desde a reunião e divisibilidade de sentidos que a palavra arkhê na noção de arquivo guarda. Gesto que marca o caráter político da questão de arquivo.

Escreve Duque Estrada:

\begin{abstract}
Sua dimensão política, indicada na simples consideração da palavra arkhê, consiste no fato de esta palavra comportar - em cada um dos dois princípios que ela reúne, aos quais já nos referimos: começo e comando - uma série de divisões e diferenciações, ou seja, uma heterogeneidade que atravessa, efetivamente e desde sempre, cada momento semântico implicado na própria genealogia da palavra. Esta heterogeneidade (...) irá, necessariamente e por razões estruturais, comprometer, complicar, contaminar, como diz Derrida, a pretensa homogeneidade ou autoidentidade do sentido de cada um desses momentos. Ou seja - e isto vale como uma primeira indicação do aspecto político aqui implicado -, a estrutura referencial implicada na palavra arkhê nunca constitui, como a princípio poderíamos supor, uma indicação imediata e segura em direção ao que nela é pensado ou significado. Ao contrário, Derrida nos faz ver, a propósito da palavra arkhê, que sua estrutura referencial é, por natureza, heterogênea, oblíqua, desviante em relação ao que nela é referido $^{308}$.
\end{abstract}

A partir dessa consideração, podemos pensar que a democratização do arquivo requer, num primeiro momento, reconhecer que arquivo já é uma palavra marcada pela divisibilidade heterogênea entre começo e comando ${ }^{309}$. A marca

\footnotetext{
${ }^{308}$ Idem, p. 4. [Grifos do autor.]

${ }^{309}$ Taylor (2013) fala também da partida entre começo e comando que etimologicamente se rastreia na palavra arquivo. Porém sua análise está comprometida em afirmar uma indivisibilidade da $\operatorname{arkhê}$, de seu comando acima do tempo e do espaço, portanto de sua aspiração à perenidade: “A memória arquival trabalha a distância, acima do tempo e do espaço; investigadores podem voltar para reexaminar um manuscrito antigo; cartas encontram seus endereços através do tempo e do lugar; discos de computador às vezes cospem pastas perdidas, com o uso do software certo. O fato de que a memória arquival consegue separar a fonte de 'conhecimento' do conhecedor - no tempo e/ou espaço - leva a comentários, como o feito por Certeau, de que ela é 'expansionista' e "imunizada contra a alteridade"” (TAYLOR, 2013, p. 48-49, grifos meus). A reflexão de Taylor sobre a arkhê está comprometida. Está comprometida com uma hipótese de que o "ao vivo" não reserva/apela distância [uma contradição com a outra passagem que vimos anteriormente, em que a autora diz que "o repertório, como o arquivo, é mediado" (Idem, p. 51). Também é comprometida ao não se interessar em cogitar que, se a noção de arquivo guarda em si o rastro duplo da arkhê, de comando/começo reunidos em uma só palavra, é porque já é em tempo e espaço divisível; já marca uma diferença divisível. Caberiam perguntas: que investigadores podem retornar aos arquivos e reexaminá-los? Todos eles? Quem forma esse eles deixado nessa pergunta? O que se arquiva n'eles? E ainda: são todas as missivas, cartas, endereçáveis e rastreadas? Claro que não. Os cartões-postais, por exemplo, circulam abertamente entre mãos e nem por isso
} 
socio-histórica que o princípio arcôntico como poder de consignação evoca reinscreve o arquivo no seu mal divisível e reiterado desde seu começo/comando, desde a sua arkhê. A reunião desses registros arquivados na noção de arquivo torna o seu pensamento ético-político oscilante e indecidível. A noção de arquivo nos diz que a lei não governa sem lugar e sem os guardiões do lugar e também que não há lugar sem a lei de participação dos guardiões, sem a sua partilha e divisão de forças.

Duque Estrada nos ajuda a pensar as implicações ético-políticas dessa divisibilidade indecidível:

Qual a importância disso? O que, afinal, pretende Derrida ao propor esta discussão? Ele quer enfatizar que o princípio nunca é um consigo mesmo; ao contrário, o que é primeiro, o que diz respeito ao começo, ao início, se constitui, desde sempre, na e pela diferença (...) Qual seria então a implicação política que se pode, efetivamente, vislumbrar a partir desta consideração? Digo efetivamente de modo proposital, pois a expectativa por uma consequência palpável desta discussão só ocorre porque, de imediato, não nos damos conta de que sempre já nos encontramos efetivamente imersos, implicados na problemática que está sendo levantada aqui. Estamos tão efetivamente imersos nesta problemática, ela está tão intimamente relacionada ao nosso modo de ser, pensar, agir e se relacionar com as coisas, que, efetivamente, não nos damos conta dela. Esta implicação política torna-se mais clara no momento em que nos damos conta, em que nos de-paramos com o fato de que a afirmação - ou o estabelecimento, ou a institucionalização - de um começo à luz do qual as coisas se reúnem em um todo, se consignam ou se arquivam, como poderíamos dizer, tornando-se então pensáveis, explicáveis, legíveis, significativas, inteligíveis etc.; enfim, no momento em que começamos a nos dar conta de que toda e qualquer afirmação de um começo? - portanto, de um princípio garantidor de ordem, estabilidade, inteligibilidade, etc. carrega em si mesma, e desde sempre, uma cisão, uma heterogeneidade, ou, mais precisamente, uma relação de diferença ${ }^{310}$.

Sofremos do mal de arquivo, incondicionalmente. Jamais renunciamos a ele, sobretudo quando pensamos nas formas de organização de práticas, estudos e proposições. As nossas práticas incorporadas, se são efetivamente incorporadas (arquivadas sob alguma experiência de reunião, recorte, estrutura ou ipseidade que

restituem o segredo enviado ao outro. Derrida escreveu sobre essa singularidade da destinação do cartão-postal e de outras missivas em O Cartão-postal: de Sócrates a Freud, Cf. DERRIDA, 2007.

${ }^{310}$ Idem. [Grifos do autor.] 
chamamos de corpo), já estão marcadas pelo problema da guarda, da memória, da história e da ontologia de uma memória, pela lembrança e pelo esquecimento, pela afirmação de certas marcas e pela supressão de outras. Estamos marcados, como corpos, pelo mal divisível e perturbador, em muitas impressões, em muitos receptáculos, superfícies, territórios, digitais, peles e ossos. É nesse pensamento paradoxal e divisível, portanto jamais absoluto, jamais imunizado à alteridade, $\mathrm{e}$ no sim-sim desconstrutível que, com Derrida, podemos reposicionar a questão do arquivo.

A partir dessa compreensão, podemos retornar outra vez aquando o pensador franco-argelino nos diz que a questão da política de arquivo "atravessa a totalidade do campo [da política] e na verdade determina, de parte a parte, a política como res publica" ${ }^{, 311}$. Essa passagem abre várias brechas para se pensar a democratização tanto da política como do arquivo. Enumero aqui três:

1 -é preciso afirmar que o arquivo é coisa pública (res publica), aberto à vinda do tornar-se público e, portanto, desconstrutível desde sua unidade-divisível reguladora. Os arquivos não governam por si, eles precisam ser acessados, manuseados, transmitidos, traduzidos de um a outro para imprimirem a sua força $^{312} ; 2$ - é preciso notar que o campo do político não se conduz sem a estrutura arquival, sem lugar e sem lei, oikos e nomos, duas palavras que também se arquivam em economia fazendo-a girar. $A$ política como res publica se dá desde a consignação do arquivo: na participação, no acesso e na divisão do arquivo; 3 - é preciso lembrar que, como já observei antes, a noção de democracia em Derrida começa e tem a força de lei de um sim, sim: sim-sim para a abertura do arquivo; sim-sim para a abertura do político: democracia por vir! ${ }^{313}$

Destacaria duas passagens finais de Mal de Arquivo (2001) que nos falam sobre a força turbulenta de tal democracia por vir. A primeira passagem diz respeito à própria anánkê [força, necessidade, restrição] que se anuncia. Sobre a autoviolência do arquivo na sua repetição de si:

\footnotetext{
${ }^{311}$ DERRIDA, 2001a, p. 16.

${ }^{312}$ Portanto, a pressuposição de Taylor de que os arquivos governam a distância, na sua perenidade indivisível ao espaço e ao tempo, sofre um abalo. Não há arquivo sem a performatividade do arquival, sem a sua iterabilidade, sem o outro por vir e sem alteridade.

${ }^{313}$ Peço que o leitor guarde, imprima, deixe marcar a reiteração do é preciso... em algum receptáculo. Retornaremos a esse apelo desconstrutivo mais adiante.
} 
Essa injunção exige prometer mas exige também a repetição, primeiramente a repetição de si, sua confirmação num sim, sim [a abertura do sim, da vinda que vem]. Inscrevendo assim a repetição no coração do por-vir, é necessário importar, no mesmo lance, a pulsão de morte, a violência do esquecimento, a sobreimpressão, o arquivo, em suma, a possibilidade de pôr à morte aquilo que, seja qual for seu nome, porta a lei na sua tradição: o arconte do arquivo, a mesa, o que sustenta a mesa e quem a sustenta, o subjetível, o suporte e sujeito da $1 \mathrm{ei}^{314}$.

A segunda passagem trata do gesto de sofrimento que a noção de arquivo guarda como sua autoimunidade. Ela se protege e se destrói, sem sossegar, como "sofrimento" e "mal de":

A perturbação do arquivo deriva de um mal de arquivo. Estamos com mal de arquivo (en mal d'archive). Escutando o idioma francês nele, o atributo "en mal de", estar com mal de arquivo, pode significar outra coisa que não sofrer de mal, de uma perturbação ou disso que o nome "mal" poderia nomear. É arder de paixão. É não ter sossego, é incessantemente, interminavelmente procurar o arquivo onde ele se esconde. É correr atrás dele ali onde, mesmo se há bastante, alguma coisa nele se anarquiva. É dirigir-se a ele com um desejo compulsivo, repetitivo e nostálgico, um desejo irreprimível de retorno à origem, uma dor da pátria, uma saudade de casa, uma nostalgia do retorno ao lugar mais arcaico do começo absoluto ${ }^{315}$.

O pensamento da democracia por vir com a noção de arquivo elaborada por Derrida é antes de tudo um "sofrimento de" abertura às suas inscrições de pulsão de morte. As consequências desse pensamento atingem as mais variadas incidências, em que o arquivo performa sua res publica; aquando o arquivo imprime, por diferentes técnicas, uma força singular de reunir e agir como força de lei nos espaços de alteridade e de partilha da experiência com o outro. Tarefa perturbadora, desassossegada, lançada ao porvir do evento arquival.

Sem poder falar de todas as consequências dessa discussão, mas também sem me furtar ao debate que vinha estabelecendo junto a algumas discussões caras aos estudos da performance, proponho agora retornar aos problemas deixados por mim anteriormente. Permitam-me retornar: "[...] Ao arquivar danças, estamos despotencializando o seu abalo performativo? A força fraca da dança se deixa

\footnotetext{
${ }^{314}$ DERRIDA, 2001a, p. 101.

${ }^{315}$ Idem, p. 118.
} 
sofrer de algum mal de arquivo? Ou, pelo contrário, pensar a noção de arquivo na dança provoca algum abalo na economia do arquival, na oikonomia que a noção de arquivo guarda em si? Essas perguntas demandam demoras distintas, $e$ não conseguiremos resolver todas elas nesta tese. Porém, sem me furtar ao debate, quero contribuir, ao menos, a partir do acúmulo e da circulação, que, acredito (como fé de um faro sem garantias), já construímos até aqui..." - deixei escrito acima.

Reitero reinscrevendo, agora, que: [“a partir do acúmulo e da circulação, que, acredito (como fé de um faro sem garantias), já construímos até aqui”...] podemos nos lançar para algumas dobras finais sobre como o pensamento da democracia por vir no sim-sim à noção de arquivo pode engendrar aberturas a outras ético-políticas para os estudos da performance/ da dança. Assim, deixarei duas últimas impressões a partir do acúmulo que performamos até aqui como um trabalho reiteradamente por vir.

$\mathrm{x}$.

A primeira impressão deixada diz respeito à passagem em que Derrida escreve sobre a anankê: "é necessário importar, no mesmo lance, a pulsão de morte, a violência do esquecimento, a sobreimpressão, o arquivo, em suma, a possibilidade de pôr à morte aquilo que, seja qual for seu nome, porta a lei na sua tradição". Trata-se de um trabalho desassossegado de revisão sempre por vir das formas de arquivo que portam a lei na sua tradição. Pensar como as tradições reinscrevem a pulsão de morte em si, reiteradamente, abrindo-se ao sim, sim do porvir de seu arquivo. Trabalho desassossegado de autoimunidade do pensamento de arquivo.

A partir dessa primeira impressão, o faro que seguimos com os estudos da performance foi o da reserva exclusiva da noção contraditória de "ao vivo" circundante nas tradições de pensamento de Phelan (1997) e Taylor (2013), que não se encerram nessas duas assinaturas, efetivamente, nem encerram as potências advindas dessas assinaturas. Sobre tal tradição, identifico, porém, que precisamos abrir radicalmente a discussão do in actu de uma performance, sua inscrição como ato performativo, como promessa injuntiva de já e quando depois — ou, nos 
termos que já propomos anteriormente, na dança espectral evocada pela conjuração de uma performance: siga-me, guarde-me, adeus!

A forma-aparição da performance, se pensada a partir da materialização desmaterializada da dança ${ }^{316}$, nos impele a considerar o arquivamento do guardeme já no seu sofrimento de constrição entre o siga-me e o adeus [outra vez: sigame, guarde-me, adeus!]. Tal arquivamento sofre do mal de supressão do tempo, sofre da disjunção injuntiva do tempo de aproximar-se plenamente já se abrindo/realizando a seu próprio fim. O parfournir ${ }^{317}$ arquivado na noção de performance é um faro que pode nos lançar para um pensamento de performance como "agoridade divisível", que só pode ser alçando dizendo-se sim-sim às marcas arquivadas nessa noção: entre o fim de um começo e o fim lançado no adeus; na disjunção injuntiva do fim como força de lei, “dar fim” e começar uma performance, e o fim como "beira", "limite", "precipício" de um adeus já de partida.

Intempestividade e impaciência que demandam tempo, demoram sem jamais repousar, como numa experiência seguida no rastro de uma dança espectral que convoca-nos ao juntar-se e ao distanciar-se, a um só tempo: de partida, já partido. Movimento por vir que vem já como uma despedida, sempre já numa repetição, numa futuridade anterior que nos convida a uma experiência com o outro. Experiência do vem, como o vem da espera sem espera de um porvir dançante.

É a partir “desse acúmulo...” sobre o pensamento espectral da dança que proporia uma outra khora para ponderar as contribuições dos estudos da performance e sua tradição. Essa composição de pensamento não se restringe aos campos da dança e da performance, pois já se arquivam nela muitos desvios e impressões deixadas que remontam outras arquieconomias e outras tradições históricas. Abre-se, então, mais de um sim, sim nesse gesto de injunção disjuntiva. Esse sim, sim não responde a nenhuma urgência de um "o que fazer?". Não instaura garantias nem nenhuma reconciliação, porque já está lançado à revisão e à abertura de novas inscrições.

\footnotetext{
${ }^{316}$ Como pensamos anteriormente através dos rastros da dança deixados por Marx e Derrida.

${ }^{317}$ Que, como vimos, na sua tradução e no câmbio entre as mais diversas línguas, arquiva noções distintas de completar, realizar plenamente, dar fim.
} 
A segunda impressão diz respeito às noções de sofrimento e perturbação sem sossego do mal de arquivo $^{318}$. Para pensa-las, irei fazer duas paragens a seguir, em dois movimentos, em tons distintos, que talvez nos ajudem a pensar o porquê ainda seguir/perseguir/performar tele-coreografias [seja no palco, seja no papel ou até na rua; ou aquando exorbitando um chão da filosofia, da dança, da política e além]. Movimento em dois tons: o primeiro tom será de um relato escrito como uma quase-carta a Finita, obra da artista Denise Stutz. O segundo tom virá da singular invocação da palavra baderna e das turbulências que se arquivam se iterando nessa palavra com os movimentos de dissidência e desobediência civil, que tomam as ruas e fazem a cidade dançar sofrendo do espectro da chamada de/chamada à baderna. Ambos os movimentos chegaram atravessados pela minha saída às ruas, aquando — ainda que por um instante saí e retornei à mesa, mudei lugares e suportes de escrita desta tese.

\section{2. \\ Uma Quase Carta. Porque Não Pude Falar: Pensando a Disjunção da Memória em Finita, de Denise Stutz}

Uma cadeira, uma mulher, uma música antiga, algumas memórias e uma blusa listrada azul de mangas compridas estirada no chão. Ela veste a blusa.

O espetáculo Finita ${ }^{319}$, de Denise Stutz ${ }^{320}$, partilha, assim, um encontro com alguém — alguém que poderia ser um amigo distante ou até mesmo eu ali

\footnotetext{
${ }^{318}$ Cito novamente (o jogo de repetições é alucinatório, eu sei, mas deixemo-nos sofrer desse mal outra vez): "A perturbação do arquivo deriva de um mal de arquivo. Estamos com mal de arquivo (en mal d'archive). Escutando o idioma francês nele, o atributo "en mal de", estar com mal de arquivo, pode significar outra coisa que não sofrer de mal, de uma perturbação ou disso que o nome "mal" poderia nomear. É arder de paixão. É não ter sossego, é incessantemente, interminavelmente procurar o arquivo onde ele se esconde. É correr atrás dele ali onde, mesmo se há bastante, alguma coisa nele se anarquiva. É dirigir-se a ele com um desejo compulsivo, repetitivo e nostálgico, um desejo irreprimível de retorno à origem, uma dor da pátria, uma saudade de casa, uma nostalgia do retorno ao lugar mais arcaico do começo absoluto" (DERRIDA, 2001a, p. 118).

${ }^{319}$ Obra de Denise Stutz estreada em outubro de 2013, no Rio de Janeiro. Vídeo do espetáculo disponível em: <<https://www.youtube.com/watch?v=UymXMKAqQyw\&feature=youtu.be>> . Último acesso em 09 ago. 2016.

${ }^{320}$ Denise Stutz é artista da dança, radicada na cidade do Rio de Janeiro. Iniciou seus estudos de dança em Belo Horizonte, onde nasceu, e foi uma das fundadoras do Grupo Corpo. No Rio de
} 
sentado, um outro qualquer convidado a imaginar uma dança sem ver. Ao longo da performance, Denise Stutz aciona as memórias de uma carta enviada por sua mãe - que também já era avó de Guilherme, único neto - , na qual lhe dissera: "Gosto dessa portuguesa que ao invés de dizer saudade diz nostalgia".

É em tom de nostalgia que ela dança, contando os estalos dos dedos, contando a pulsação dos seus passos e também nos contando as imagens todas que estão para irromper nesse encontro marcado. Conta "para não escutar o silêncio", a distância abissal entre um passo e outro, uma memória e outra, ela e o público. E assim ela nos repete: "é preciso contar".

A dança de Denise parece uma pequena máquina de escapes. Em meio a suas memórias, a bailarina, que em sua trajetória carrega tantos encontros e experiências na dança, faz citações a espetáculos que poderiam dançar aquele estar com o outro no escuro: "um chão carregado de cravos vermelhos", "um espaço que de repente ficasse todo preto de gente", "um palco de pelúcia marrom" ou "um, e não 100 gestos, que fosse capaz de dizer tudo"321. Denise, assim, nos convida a imaginar que sua dança poderia ser qualquer dança. Qualquer uma que celebrasse o encontro. Uma dança assombrada pelas danças de outros amigos e pela lembrança da loja de discos que não está mais na Barata Ribeiro com Santa Clara, no bairro de Copacabana - a qual eu nunca conheci, pois, quando me mudei para o Rio, ela já não estava mais lá.

Mesmo sem ter vivido aquelas memórias de Denise, sem ter assistido a Bagdad Café, sem ser personagem de quase nenhuma daquelas cenas citadas, em algum momento fui capturado e convocado a dançar com ela. Seja por memória individual ou coletiva, quem dança com Denise é convidado a pensar no singular encontro que é estar ali. Sim, é certo que assim o é toda dança: singular. Mas, ao nos ativar tantas imagens que nunca se completam na agoridade de sua

Janeiro, trabalhou durante 10 anos com a Lia Rodriguez Companhia de Danças como bailarina, professora e assistente de direção. A partir de 2003, começou a desenvolver seu próprio trabalho solo, com destaque para: DeCor (2003), Finita (2013) e Entre Ver (2015). Blog da artista: $<<$ https://denisestutz.wordpress.com>>.

${ }^{321}$ Todas essas citações são as que de alguma forma consegui rastrear com outras danças já incorporadas na minha experiência/experimentação. São rastros diversos: Cravos, de Pina Bausch (ALE); De Repente Fica Tudo Preto de Gente, de Marcelo Evelin (BRA); Natureza Monstruosa, de Marcela Levi e Lucía Russo (BRA/ARG); 100 Gestos, de Dani Lima (BRA). A estratégia de citação de Stutz não circula somente nesses rastros nem oferece nenhuma garantia do que se arquiva neles. Ela cita e conta muitos outros que já nem me lembro, nem pude lembrar, nem perceber na des-aparição de Finita. Talvez, o gap entre memória e percepção, como a escuridão e também o silêncio do qual não pude falar, é já uma instauração do out of joint do tempo e do evento que Stutz, dançando, faz curto-circuitar. 
performance, Finita se coloca como uma máquina espectral de fazer des-aparecer danças tão outras (dos outros) que me fez crer, por instantes, que poderíamos não estar ali nem eu nem aquelas coisas invocadas. Mas eu estava e aqueles fantasmas todos também. Disso, a contingência criada por Finita não me deixava esquecer.

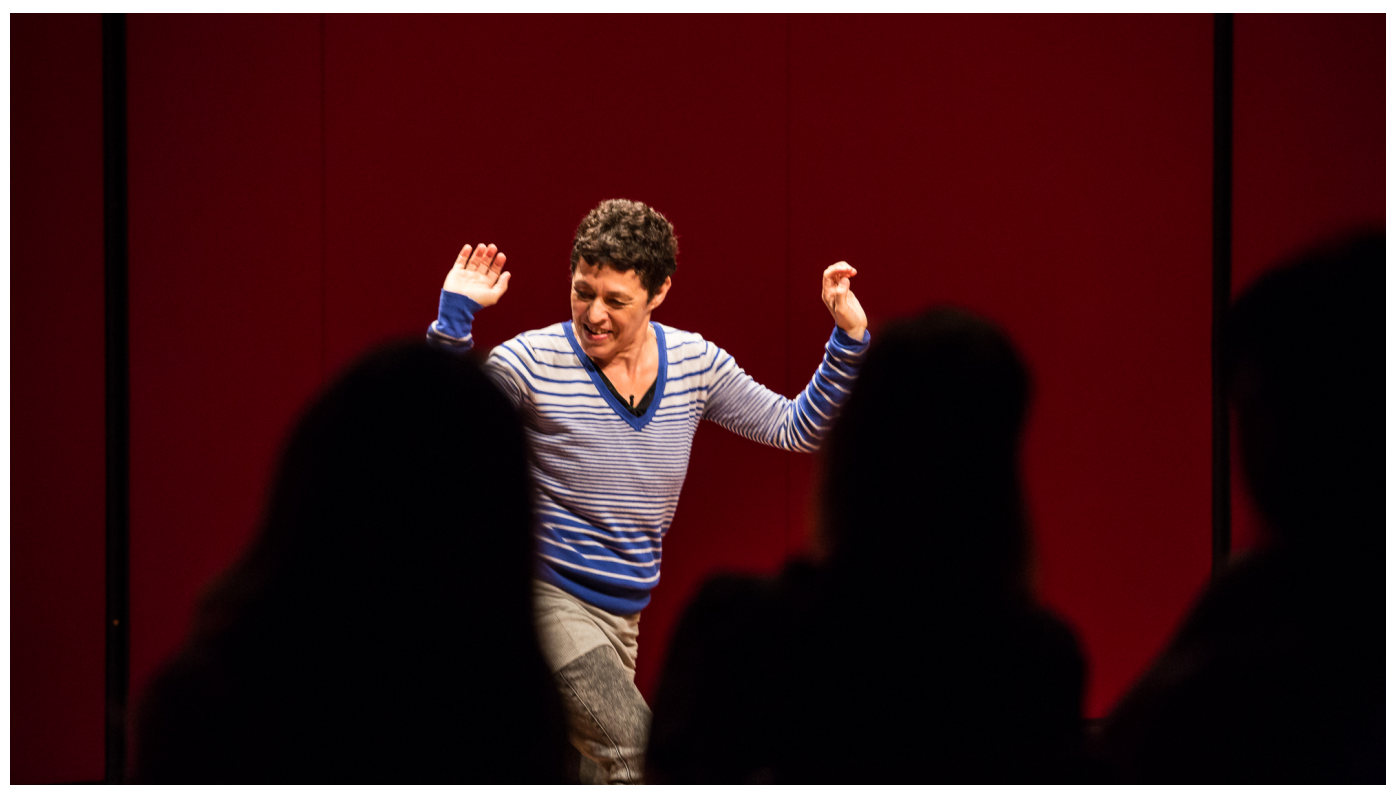

Denise Stutz em Finita (2013). Foto: Renato Mangolin, 2013.

Após o espetáculo, eu não consegui falar muito com Denise. Não sabia o que tinha que dizer. Afinal, o que se tem que dizer a alguém que nos conta nostalgias tão suas? O que dizer diante das perdas de alguém ou diante do que passou? Seria uma dança, uma carta, uma biografia, a perda?

Assisti Finita na tarde do dia 25 de outubro de 2013, no Festival Panorama, durante a sessão para o Programa Educativo do Festival, na sala acústica da Cidade das Artes (RJ). Era a estreia do Festival, para poucos. A plateia estava composta de uma série de jovens da Rede Municipal de Educação do Rio, e entre eles estavam alguns alunos da Escola Estadual Dr. Alberto Sabin que tinham algum grau de surdez. Como boa parte da dança era falada, ao lado, no canto esquerdo do palco, uma intérprete de libras traduzia as palavras de Denise. Aqueles que assistiam à intérprete de libras traduzindo as "contagens" e “contações" de Denise não conseguiam ver, ao mesmo tempo, os outros gestos rascunhados pela bailarina que dançava enquanto falava. Olhar tradução em libras 
(à esquerda, quase na penumbra), olhar a bailarina (à direita). Lá e cá, entre elas, outra vez, aquele vazio, o qual Denise disse preferir encher de contagens para não escutar o silêncio — que nunca foi ausência de som nem de sentido.

[Quais trilhas sonoras tocam quando você se sente só?]

$\mathrm{Na}$ saída da sala acústica, alguns participantes do Laboratório de Crítica $^{322}$ iniciaram uma discussão sobre a contingência daquela tradução que em algum momento criava uma hierarquia entre o som que se falava e o corpo que se movia no espaço. Mas não seria "próprio" da nostalgia tal improbidade ou impropriedade, perda ou rapto, parasitologia ou assombro? No encontro com o outro, não estaríamos desde sempre todos surdos? As ruínas de pensamento memórias - não são esse gap espaço-temporal que não nos deixa nunca viver plenamente a agoridade, mesmo que essa agoridade seja uma dança? Essa não seria a dança mesma, a coisa acionada por Denise Stutz naquela tarde?

Talvez porque essas perguntas todas me roubavam a atenção enquanto [eu] [ela] dançava foi que, no corredor, após o fim de Finita, momento que ao mesmo tempo era intervalo entre uma performance e outra da programação do Festival, ao reencontrar Denise, não soube o que lhe dizer [e esse the pode ser transferido a você que lê agora].

[Não soube o que lhe dizer, repito.]

Engraçado que durante a apresentação de Finita, algumas poucas horas antes desse reencontro no corredor, ela veio até mim, sentou numa cadeira vazia na plateia, logo à minha frente, e me perguntou se aquela dança que estava para acontecer não poderia ser como uma das tantas danças que vi nos palcos cariocas

\footnotetext{
${ }^{322}$ O Laboratório de Crítica é um espaço de discussão dentro do Festival Panorama que coordeno desde o ano de 2012, a partir do convênio entre a Associação Panorama e o curso de Teoria da Dança do Departamento de Arte Corporal da UFRJ. Nesse dia de encontro, nos diálogos pósespetáculo, estavam: Alexandre Wilson (Xandu), Alface Cátia Leitão, Lígia Tourinho, Mariana Bittencourt, Mariana Callegario, Neidimar Santos, Silvia Chalub e eu.
} 
nos últimos dois anos. Melhor, ela não me disse diretamente quais danças eram essas, mas, pelas imagens em ruínas que me foram acionadas quando interpelado, sem titubear lhe acenei a cabeça dizendo sim. Sem demora, pensei que naquele palco vazio, talvez, poderia tomar lugar uma dança de Lia Rodrigues, de Marcelo Evelin, de Marcela Levi, de Dani Lima ou talvez minha. Talvez, poderiam aparecer também os cravos vermelhos de Pina Bausch, os quais só vi em vídeo pela internet . E, ainda, talvez, poderiam insurgir outras tantas possibilidades que não consegui capturar enquanto dançava. Pensei sem pensar: "Sim, sim, Denise". Poderia vir qualquer dança, desde que fosse um encontro como esse que é singular. Uma dança pode sempre ser qualquer outra, desde que ainda singular. Uma dança pode arquivar outras danças sendo ainda singular.

Mas no corredor, longe do palco, assombrado por todas essas danças, quando reencontrei aquela mulher, que nada me perguntara sobre seu solo naquele momento, somente a abracei, dei-lhe um beijo desarranjado e disse, sorrindo: "finita".

Finita aciona a acontecimentalidade das memórias que escapam, das distâncias que de tão longe nos perseguem lado a lado. Há buracos. As coisas faltam e as mães, as mulheres finitas, também... A dança $f a z$ [a] falta. O fim, como o fim de um espetáculo, também faz falta. O som que tocava numa das cenas, inclusive, falhou. Engasgo[u].

Finita me faz lembrar, talvez, que as coisas quando faltam podem engasgar e que um certo mutismo, mesmo cheio de "contagens" e "contações", é incondicional.

Ao seu comando, apagaram-se as luzes da plateia, acenderam-se as luzes do palco. E nele o público foi convidado a imaginar-dançar a dança, como aquele que tenta colar e saltar as ruínas todas lançadas por um corpo ao som da única música que, em silêncio, se repetiu em todo o espetáculo ${ }^{323}$.

\footnotetext{
${ }^{323}$ A música é a suíte ${ }^{\circ} 14$ d'O Quebra Nozes, de Tchaikovsky, que ambienta o momento do grand pas de deux do balé. Denise dança com o público e faz o público dançar assombrado pelos arquivos da memória histórica da dança, fazendo uma inversão dos lugares de se dar a dança: "nesse momento, a luz da plateia se apaga" - diz ela conduzindo com os braços o fad out das luzes do palco, aonde ela está sentada; anuncia seguida: "a cortina abre e o palco está todo iluminado/ todas as luzes se acendem”, retornando ainda em penumbra as luzes sob nossas cabeças. Dançamos ai com mais de um espectro, justamente, assombrados por uma música composta para um "pas-de-deux" (passo de dois).
} 
[Antes de começar a escrever este texto, me perguntei em qual tom deveria encená-lo. Como quando se escreve uma carta para alguém distante, alhures, e não se sabe se e como ela vai chegar, mas ainda há o envio. Ou, ainda, com a dúvida que se faz presente quando se escreve para o outro que, mesmo estando ao meu lado agora enquanto escrevo, permaneceria como uma cadeira vazia na mesma fileira da plateia de um teatro. Esse "ele", "ela" ou "it" a que envio nunca estará aí plenamente junto e acordado - essa palavra tão dupla que ao mesmo tempo remete ao despertar e ao contrato que se faz com alguém, no qual se assina e se diz: "está acordado entre as partes". Como se assina um contrato estando incondicionalmente longe? [...] Certamente inventei outros parasitas, traças, que não retornam aos escritos de Finita. Você poderia ouvir as palavras que eu digo? Espero que não. Espero que estejamos sempre surdos e que precisemos das traduções infinitas, com ou sem libras, que nos criam ainda mais buracos e nostalgias. Talvez seja esse um dos tons que aqui tentei assinar: um perdão pela falta que se fez naquele reencontro da tarde de sábado].

Assino.

\section{3. \\ De Outra Turbulência: Chamada de/ Chamada à Baderna}

É preciso falar de outra turbulência que urge na experiência social contemporânea. Outra turbulência, disse, mas ainda perseguirei um rastro que vimos construindo. Abrindo a discussão, lanço uma chamada à responsabilidade: é preciso falar dos acontecimentos de dissidência política que têm invadido as telas, as mãos e as ruas, sobretudo nos últimos tempos [e que tempos são esses, de que direito chamá-los? Outra vez a urgência do fim, desse último fim, que se anuncia quando alguém diz: nesses últimos tempos. A quem ou a que pretendemos nos reportar?]. Os últimos tempos têm também nos arrastado ao redimensionamento não somente do espaço público e da maneira como 
articulamos/pensamos o político como res publica. A reflexão do como fazemos política instaura uma indissociabilidade entre ética e política e nos convoca a um debate sobre o problema da disjunção irremediável do estar com o outro sobretudo no espaço urbano - esse modo de vida, reunião e partilha do solo singular [" $e$ comum somente para alguns", permitam-me formular assim entre colchetes].

Se pensarmos que o estar com é um dos incondicionais do urbano e que pressupõe práticas de alteridade, quais gestos de acolhimento e de denegação iteramos em nome do urbano ou, ainda, em nome da cidade, de um certo modo de vida na cidade? No encontro com o outro radical [não somente do outro como semelhante - o outrem, mas o outro como toda vinda que vem já de partida, já escapando, já na sua outridade irredutível: seja humano, animal ou leviatã; seja de um que ou um quem vem; a diferença, a temporização e a dis-junção do espaçotempo; a turbulência, a catástrofe e a destruição], como as práticas corporais e corporativas, as instituições e as formas de reunião, de circularidade e de mobilidade agenciam, acolhem e resistem às forças "indomáveis", "desviantes" e “incapazes" de constituir ou de enunciar um nós — pelo menos não na mesma língua que interpela o $t u$, num lance disseminativo que incorpora já excorporando? Pensaremos passo a passo. Aguardemos.

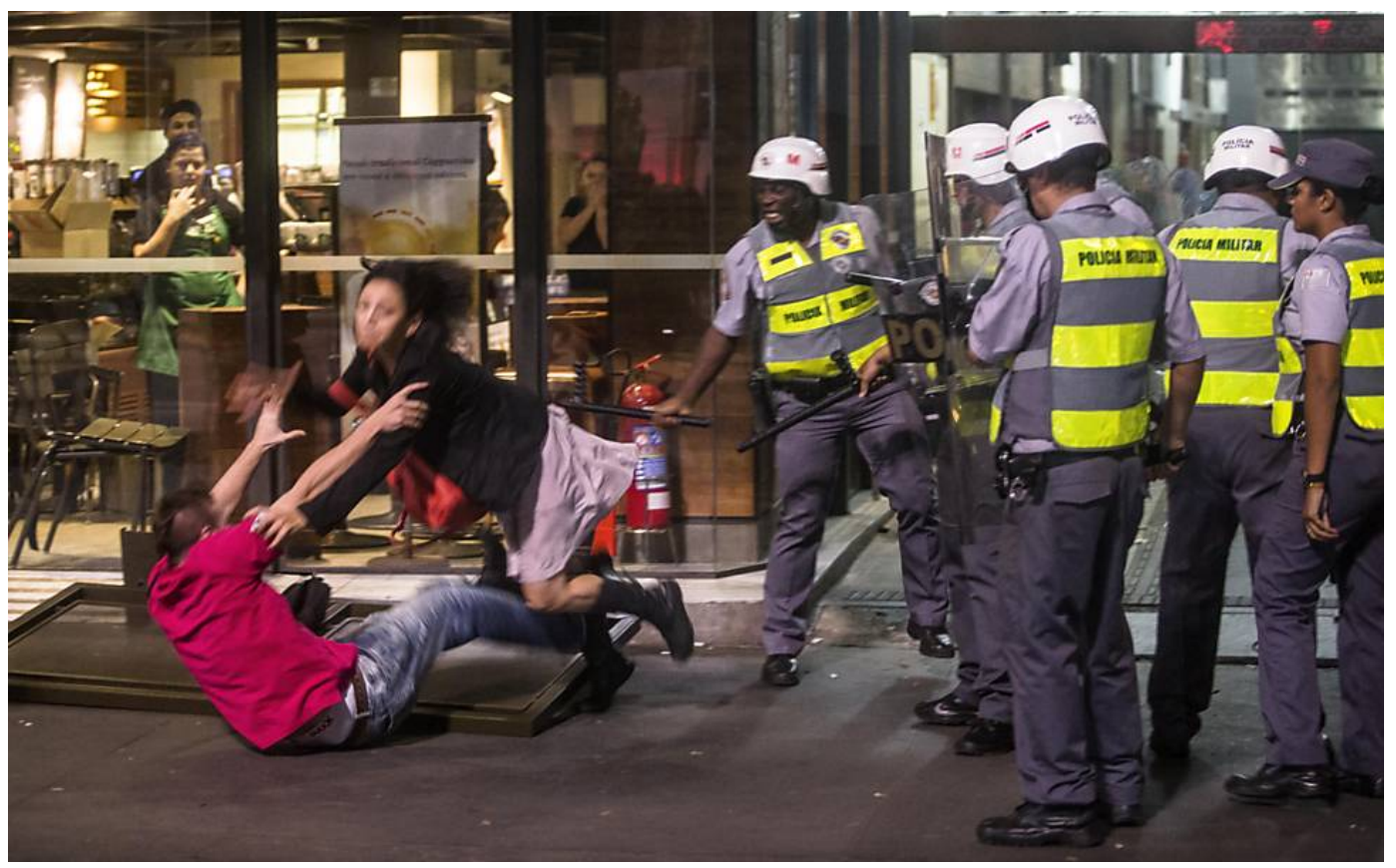

"Porrete nos Baderneiros" - Matéria do Jornal Eletrônico News Rondônia, 18 de julho de 2013. 
Observemos, de partida, no Brasil, o uso indiscriminado do termo baderna e baderneiros pelos meios de comunicação - e não somente por eles ao se referir às forças dissidentes que acompanham as diversas manifestações sociais que tomaram as ruas da cidade do Rio de Janeiro e de outras capitais brasileiras, como São Paulo, Salvador, Goiânia e Belo Horizonte, desde junho de 2013. Quero aqui me demorar sobre esse chamamento, baderna bastante local e singular.

Tal como nos aponta Silverio Corvisieri, autor de Maria Baderna - a bailarina de dois mundos (2001), é ainda pouco sabido, mas o termo baderna enquanto desígnio - substantivo "pesadamente vulgar" [nas palavras de Corvisieri] de uma força dissidente — aparece desde o Dicionário Aurélio assombrado por uma dança de alhures, reinvocada em muitos momentos, de boca a boca, papel a papel, reservando à cena-baderna um segredo. Peço desculpas pela larga citação que terei que fazer a seguir, mas creio que será um desvio mais que oportuno:

No Brasil muitas coisas são sumariamente qualificadas de baderna, embora seja possível agrupá-las em dois filões principais; o primeiro se refere a qualquer tipo de desordem pública, de confronto violento, de rixa; o segundo tem a ver com qualquer tipo de transgressão grupal (orgia, pândega, pagode). Não é de se espantar que nos anos da ditadura militar, e sobretudo depois de 1968, a palavra baderna tenha adquirido um sentido extraordinário: na visão autoritária dos generais, os rapazes de cabelos compridos demais, os contestadores, os revolucionários, os apóstolos da revolução sexual nada mais eram que uma enorme, vergonhosa e indistinta baderna. Otto Lara Resende [escritor do jornal $O$ Globo que, em 1987, publicou um artigo sobre a explosão da cólera popular no Rio de Janeiro devido ao aumento das taxas de transporte, quando oportunamente jornais e televisões deram espaço à grande "baderna" que transformara a cidade num campo de batalha num período em que o País vivia atormentado pela alta inflação e pela tensão do início do processo de redemocratização pósditadura militar] reporta a seus leitores que o autorizado Dicionário Aurélio se limitava em afirmar que a palavra em questão tinha origem em Marietta Baderna, "dançarina italiana que esteve no Brasil em 1851". Nada mais. Daí a necessidade de concluir o artigo com uma pergunta: mas que diabos terá feito esta moça para que seu nome percorresse tão tortuoso caminho semântico? O Globo é o maior jornal conservador do Brasil, enquanto o Jornal do Brasil, seu forte concorrente, tem características mais progressistas. Foi exatamente das colunas deste que Moacir Werneck de Castro, no dia 11 de julho de 
1987, quis responder à pergunta de seu colega e amigo com um artigo que, desde o título, prometia descobrir "a verdadeira história de Maria Baderna" e que continha revelações, no mínimo, sensacionais. (...) Baderna, "agente da subversão internacional", segundo Moacir Werneck de Castro, levou por algum tempo a vida dupla no Rio de Janeiro: de noite os espetáculos no teatro, de dia a conspiração sediciosa. "Com sua arte e sua peregrina beleza empolgava as plateias e levava ao delírio os moços burgueses e aristocratas que até então desconheciam a sublimidade do balé... por causa da maravilhosa bailarina houve brigas tremendas que tomaram o nome de badernas. Mas a nossa Marietta estava em outra, só pensava na Revolução com R maiúsculo" ${ }^{\text {"24 }}$.

Atento à virtualidade que o termo baderna foi tomando no Brasil, Corvisieri, por sua vez, militante do Partido Comunista Italiano, decidiu ir atrás dos rastros dessa bailarina que teria provocado indícios de uma revolução popular no Brasil, aliada aos movimentos abolicionistas de seu período. No entanto, ao chegar na primeira fonte, Moacir Werneck de Castro [Jornal do Brasil], Corvisieri descobre que o artigo de 11 de janeiro de 1987 não passava de uma "fábula, tudo inventado, com possível simulação de verossimilhanças na sequência de acontecimentos históricos brasileiros dos quais ela (Baderna) teria participado". Confessa Castro: "Errei por não ter deixado clara minha intenção, eu que não estou habituado ao gênero humorístico"325. A partir dessa revelação desse relato em tom de confissão - Corvisieri inicia sua pesquisa sobre a biografia da bailarina.

Por uma questão de tempo, sem poder me demorar tanto em sua biografia $^{326}$, apenas irei apontar que Maria Baderna, também conhecida como Marietta Baderna, foi uma bailarina que viveu o auge do romantismo do balé no século XIX. Saiu refugiada da Itália para o Brasil, em 1848, junto a seu pai e outros artistas que abandonaram seu país natal por conta da derrota nacionalista e do recrudescimento da repressão austríaca. Conta a biografia assinada por Corvisieri que a história da bailarina é atravessada por entusiasmo de seus fãs, registrados em inúmeros artigos e folhetins da época, que avigoravam o mitoBaderna "com sua beleza física e com seu talento de sílfide etérea. Anjo e

\footnotetext{
${ }^{324}$ CORVISIERI, 2001, p. 20-21, [Comentários meus].

${ }^{325}$ CASTRO apud CORVISIERI, 2001, p. 23, [Grifos meus].

${ }^{326}$ Até porque não é essa questão que me interessa aqui, sem tirar o mérito e a importância de tal estudo e concedendo-lhe toda a minha tributação.
} 
demônio"327, nas palavras de Corvisieri. A palavra baderna foi usada, num primeiro momento, como um sinônimo de graça e elegância na dança, como evidenciado no Correio Mercantil de 06 de janeiro de 1850, em um artigo sobre o balé La discepola dell'amore:

(...) no citado balé as ninfas surgiram da água e dos bosques para "badernar", ou seja, para dançar elegantemente, para divertimento e satisfação do povo fluminense; falou depois da "badernice" (graça, coqueteria) de Marietta, confirmando a difusão da moda de conjugar o sobrenome da bailarina com todo tipo de tempero (mas por enquanto temperos de ótimo sabor) $)^{328}$.

Entre os anos de 1850 e 1851, Marietta Baderna viveu o auge da polêmica em torno da sua dança no Brasil. No período, em sua temporada pela cidade do Recife, Baderna protagonizou uma discussão acirrada nos pilares da cultura escravista e colonial quando decidiu incluir nas suas performances, no Teatro de Santa Isabel - equipamento cultural símbolo da burguesia romântica local -, danças populares negras, como os fados, lunduns e baianos, que eram consideradas indecentes e imorais. No seu retorno ao Rio de Janeiro, enquanto esperava a retomada da temporada lírica, começou também a arrastar uma legião de admiradores, os chamados badernistas, por protagonizar grande furor nos bailes da cidade. O período que foi nomeado de febre dançante, devido ao crescimento da ocupação da dança festiva nas praças, salões e espaços públicos, gerou polêmicas entre "aqueles que temiam a ruína dos virtuosos costumes patriarcais e aqueles que, ao contrário, viam na paixão pela dança uma manifestação de vitalidade em sintonia com o progresso tecnológico e a modernização geral que envolvia, naqueles anos, também a capital do Brasil’329.

A febre dançante era ainda acompanhada pelo assolamento da febre amarela que havia matado muitas pessoas no Brasil. As festas eram consideradas verdadeiros núcleos de transmissão da doença, e não demorou muito para que Baderna, e sobretudo os badernistas, virassem sinônimo de indecência ou caminho da perdição: "uma verdadeira escola de prostituição. A Marietta, no centro daquele mundo, foi atribuído o papel primário de 'corrupção' das moças

\footnotetext{
${ }^{327}$ CORVISIERI, 2001 , p. 91

${ }^{328}$ Idem., p. 104.

${ }^{329}$ Ibid., p. 133.
} 
cariocas e desencaminhamento dos jovens admiradores" ${ }^{, 330}$. Segundo as pesquisas de Corvisieri, os excessos libidinais do romantismo conferidos ao furor baderna foram também levando-a à decadência nas peças líricas, sendo menosprezada e rebaixada à apresentação de números finais das óperas, quando a plateia já estava cansada após os largos programas. Os jornais passaram a tratar os números de dança como entretenimento erótico para uma plateia predominantemente masculina que ia ao teatro ver pernas e seios em movimento, admirando a beleza das formas corporais das bailarinas e pouco focando nas suas danças. As críticas a Marietta Baderna passaram a não mais exaltar a sua sublime força dançante, levando os badernistas a encenar protestos tempestuosos contra os ultrajes à sua bem-amada, resultando "em muitos casos prelúdios de confrontos físicos que provocaram a intervenção da polícia e a indignação dos paladinos da ordem pública",331.

Nos rastros dessa historieta que aqui acabo de telegrafar, me parece pertinente pensar na disseminação do espectro baderna enquanto um acontecimento iterável. Desde os moralismos que fizeram Marietta Baderna de musa romântica a ícone da prostituição, a apropriação do termo pelo governo militar, a falta de intenção de Moacir Werneck de Castro que lançou baderna como uma força revolucionária por mera verossimilhança — sem nunca ter ido de fato atrás de sua história —, bem como as infinitas invocações desse termo para rechaçar o outro que vem desorganizar um certo estado de direito, o porvir baderna que dança abre uma brecha acidental e oportuna para se dar-a-pensar telecoreograficamente como modos de composição de forças lidam com as dissidências que podem chegar sem ser convidadas e dar espaço ao desvio.

É preciso destacar que o reaparecimento da baderna como interpelação que criminaliza e bestializa os movimentos sociais dissidentes configura uma questão ético-política recorrente a situações em que a soberania é colocada em xeque. O soberano - essa figura que, como lembra Bennington (2015), desde a Política de Aristóteles já era associada à noção de homem acima da lei, acima da polis, e ao mesmo tempo capaz de fundar a lei dos homens - sempre esteve acompanhado, senão perseguido, pela noção de "homem incapaz de entrar em uma parceria, ou tão autossuficiente a ponto de não precisar fazê-lo, [que] não é

\footnotetext{
${ }^{330}$ Ibid, p. 180.

${ }^{331}$ Ibid, p. 162.
} 
parte de um estado e deve ser, então, um animal inferior ou um Deus" ${ }^{\text {,32 }}$. Derrida, em A Besta e o Soberano (Vol. I) ${ }^{333}$ retoma a discussão do jogo de sedução entre besta e soberano presente na retórica política contemporânea que acusa aqueles que não respeitam os estados soberanos como "rogues States" ["États voyous", em francês; "Estados vadios", na tradução portuguesa de Fernanda Bernardo]. De acordo com essa retórica, rogue States são:

[...] estados delinquentes, estados criminosos, estados que se comportam como arruaceiros [brigands], como salteadores de estrada ou como vulgar rapscallions que apenas fazem o que querem, não respeitam o direito internacional, estão à margem da civilidade internacional, violam propriedades, fronteiras, regras e boas maneiras internacionais, incluindo as leis de guerra (o terrorismo sendo uma das formas clássicas desse tipo de delinquência, de acordo com a retórica dos líderes dos estados soberanos que por sua vez afirmam respeitar os direitos internacionais). Agora, État voyou é uma tradução do inglês rogue, rogue State (em alemão, Schurke é a palavra para traduzir rogue, que pode também significar patife, salafrário, impostor, trapaceiro, ralé, canalha, criminoso). Rogue States, em inglês, parece ter sido o primeiro nome (voyou and Schurke são meramente traduções, eu acho), para a acusação que foi formulada em inglês, pelos Estados Unidos. ${ }^{334}$

Derrida segue seu argumento nos mostrando que, em geral, a acusação de rogue States retorna para o acusador. Afirmam os acusados que os acusadores são os precursores: "os verdadeiros rogue States são os soberanos, poderosos e hegemônicos Estados-nação que começaram a não respeitar a lei ou os direitos internacionais, aos quais eles afirmam estar se referindo, e que há muito tempo praticam terrorismo de Estado, que é apenas uma outra forma de terrorismo" ${ }^{\text {"335. }}$. Como lembra Derrida, os Estados Unidos são um dos primeiros casos onde o acusador é também acusado. “Os Estados Unidos são acusados de prática de terrorismo de Estado e, regularmente, de violação das decisões das Nações Unidas

\footnotetext{
${ }^{332}$ ARISTÓTELES 1944 apud BENNINGTON, 2015, p. 37.

333 “O seminário intitulado 'A Besta e o Soberano' foi o último seminário dado por Jacques Derrida na École des Haut Études en Sciences Sociales (EHESS), em Paris, do outono de 2001 à primavera de 2003" (N.E. in DERRIDA, 2009b, p. 14). A sessões do seminário foram transcritas, organizadas em dois volumes e publicadas após a morte do autor, em 2009.

${ }^{334}$ DERRIDA, 2009b, p. 18-19. [Tradução minha].

${ }^{335} \mathrm{Ibid}, \mathrm{p} .41$.
} 
ou das agências de direito internacional, e por isso eles são tão rápidos em acusar os outros, os tão chamados rogue States, de violação" ${ }^{336}$.

Rogue é recurso retórico/armamentista que determina os "estados fora da lei”, que, em suma, seriam estados que agridem a democracia, sobretudo a democracia [ou o modelo de democracia] estadunidense e de seus aliados. A noção de rogue States foi usada por George Bush para se referir ao evento de 11 de setembro de 2011 e também para justificar o plano nacional de segurança de Robert Litwak, que declarou: "A rogue State is whoever the United States says it is ${ }^{, 337}$ [Um rogue State é qualquer um que os Estados Unidos disser que é]. Derrida irá arrematar então que, se os EUA têm o poder de decidir investir 60 bilhões de dólares num sistema de míssil e antimíssil contra um rogue State, contra a soberania e a possibilidade de qualquer estado responder por si, eles, e por vezes seus aliados, seriam então "os mais perversos e os mais violentos, os mais destruidores dos rogue States" $" 338$, pois seriam desde sempre essa força sobre o outro, sobre o poder tirar o outro de si, o poder destruir o outro. A soberania construída sobre tais partilhas sobre o outro. Para Derrida, a vadiocracia é própria a toda cracia da soberania de Estado, “aí onde não há senão vadios, não há mais vadios. Plus de voyous [não (há)/mais vadios]"339.

Não poderei aqui me demorar no argumento que segue o pensamento derridiano sobre o tema, porém quero pensar nessa correlação entre a internacionalização da acusação arbitrária de rogues, voyous, schurke - que foi traduzido por Fernanda Bernardo, para o português, como vadio - com a igual arbitrariedade que a acusação "baderneiro" tem reencenado no Brasil. Particularmente, não acredito que a tradução por vadio - ao menos no Brasil tenha o mesmo apelo que rogue, voyou ou schurke.

Em seu último livro publicado em vida, Voyous (2003) — traduzido por Bernardo como Vadios (2009) —, Derrida faz associações entre o adjetivo francês roué (rodado) e o substantivo rouerie (libertinagem). Esta última palavra designa todo aquele ou toda ação que se desenrola no sentido maldoso ou maléfico. "A libertinagem [rouerie] mereceria assim a roda [roue], a saber, o suplício que consiste em ser-se 'roué' ['rodado']: em ver-se moer de pancada na roda ou, em

\footnotetext{
${ }^{336}$ Idem.

${ }^{337}$ LITWAK, 2001 apud DERRIDA, 2009c, p. 183.

${ }^{338}$ DERRIDA, 2009b, p. 183.

${ }^{339}$ Idem.
} 
todo caso, punir por ter infringido a lei ou os bons costumes" ${ }^{340}$. Um roué [rodado], enceta Derrida, "é um desviado, uma espécie de voyou" "341. Um voyou é um desviado, e o devir voyou também nunca está longe da cena de sedução. Alerta Derrida, porém, que, "na grande veia da diferença sexual - que atravessa, pelo menos virtualmente, toda a história da democracia e do seu conceito" ${ }^{\text {342 }}$, nas suas palavras, torna-se bastante secundário e superficial colocar o voyou no feminino voyoute "como nos obrigamos por vezes a dizer sem convencer" 343 . Mais adiante, Derrida ainda associa tal sedução à palavra rue (rua), lembrando que nesse desvio desconstrutivo não há "qualquer relação etimológica com roué ["rodado"] ou com rota, mesmo se a rua é o lugar privilegiado dos rodados [roués], o meio e a via [voie] dos voyous: é aí onde na maioria das vezes eles circulam"344.

Talvez, pelo deslize da virtualidade da letra entre roué, roue, rue [rodado, libertinagem e rua] até voie [via] e voyou, Fernanda Bernardo chegou à tradução de voyou por vadio em português. No entanto, considero que vadio não seria tão oportunamente associável ao corte de gênero dado por Derrida, mencionado acima. Os rastros da sociedade machista e patriarcal brasileira, em algum momento, deixam escapar o vadio, no masculino, não mais como um termo injurioso, mas, sim, uma qualidade, uma quase hipérbole, do éthos de macho. Num eufemismo tacanho, o macho brasileiro é quase-orgulhosamente um vadio - uma espécie de casta privilegiada de nossa herança socio-patriarcal, reiterada cotidianamente pela performance hegemônica e heteronormativa de gênero.

Não podemos afirmar que, ao menos no Brasil, o termo no feminino, vadia, seja "superficial” e "secundário" que dizemos "sem convencer". Pelo contrário, em português brasileiro, esse é um dos performativos injuriosos mais eficazes para se criminalizar, macular, infamar, desonrar uma mulher que se comporta tal como um homem vadio. Vadia é o termo arbitrariamente atribuído àquela que usa da liberdade e da libertinagem de seu corpo, uma mulher da rua, uma incitadora da desordem e dos bons costumes, uma imoral, na tradução animalesca, uma "cadela suja" ou, simplesmente, "uma mulher que se veste como vadia, pedindo para ser estuprada". Aqui não posso deixar de citar a

\footnotetext{
${ }^{340}$ Derrida, 2009c, p. 67.

${ }^{341}$ Idem.

${ }^{342}$ Idem., p. 68.

${ }^{343}$ Idem. [Os grifos são meus]

${ }^{344}$ Idem., p. 69.
} 
contrarresposta do movimento feminista Marcha das Vadias (SlutWalk), surgido em Toronto, em 2011, e disseminado por outras grandes metrópoles mundiais pelo fim da culpabilização das vítimas nos casos de violência sexual contra mulheres. Vadia é uma vadia, ou melhor, é tudo aquilo que dizem que uma vadia é. Porém, quando mulheres se organizam e passam a dizer "eu sou uma vadia", há um arrombo no sistema patriarcal que não podemos chamar de superficial nem secundário.

A tradução de Bernardo é anterior à insurgência da Marcha das Vadias, mas não é anterior a esse duplo corte patriarcal que qualifica um vadio como eufemismo e uma vadia como injúria. Não esqueçamos que o contrato social de gênero sempre foi acompanhado da formação fabulosa do homem na rua e da mulher em casa. A mulher que sai à rua para rodar, sem um homem que esteja a rodeá-la é uma vadia. Sempre houve vadio e vadia, em forças dissimétricas, mas jamais superficiais. Traduzir "voyou" por "vadio" arrastará consigo esse enceguecimento vernacular.

Minha desconfiança é de que, ao menos localmente, no Brasil, baderneiro reserva alguma particular associação com as traduções rogue, voyou e schurke apontadas por Derrida. Talvez não como uma mais apropriada tradução, mas, ao menos, tal tradução desviante forçaria um pensamento sobre a violência ética da interpelação "tu, baderneiro" atribuída aos movimentos sociais dissidentes, lembrando que o poder de interpelação parte desde uma força do mais forte ou, ainda, da força do direito e pelo direito como força: quem de direito diz "tu, baderneiro"?

O jogo de atração e de sedução evocados por baderna — desde a sua espectral biografia com rastros do transbordo e do pavor do sublime até as arruaças e os protestos - são como o envio e o chamado à democracia por vir pensados Derrida. O vem e o vai da baderna, entre bocas, telas e as mais diversas superfícies, entre esquecimento e memória, são performativos em que ainda precisamos nos demorar.

Enfatizemos esse poder dizer "tu, baderneiro" como um "tu, voyou", essa ipseidade que já impele uma alteridade radical desde a partida. A interpelação tu 
marca uma dependência fundamental do outro - acolhendo-o desde a boca de quem o profere - para a constituição de um éthos coletivo, o nós que acusa para relatar a si como não baderneiro.

Judith Butler, em seu livro Relatar a si Mesmo: crítica da violência ética (2015), refletindo com a filosofia de Adorno, nos oferece uma distinção entre as noções de moral e ética que pode ser uma chave de leitura pertinente para se pensar a interpelação da baderna pelo éthos coletivo. A autora observa que é somente na possibilidade de interpelar e ser interpelado, frente a um tu, que um sujeito pode se relatar a si mesmo, como uma forma de dizer que "recorre à voz e à autoridade narrativas, direcionadas a um público com o objetivo de persuadir" ${ }^{345}$; ou seja, acusa-se um $t u$ a fim de fazer justiça como uma defesa de si, operando uma violência ética desde a língua.

Butler nos diz que Adorno, embora muitas vezes utilize os termos ética e moral de maneira muito parecida,

(...) prefere usar em sua obra o termo 'moral' (...) [como] qualquer conjunto de máximas ou regras [que] devem ser apropriadas por indivíduos. Considerando que se possa reservar o termo 'ética' para se referir aos amplos contornos dessas regras máximas, ou para a relação entre si-mesmos implicada por essas regras e máximas, Adorno insiste em que a norma ética que não oferece um modo de vida ou que se revela, dentro das condições sociais existentes, como impossível de ser apropriada tem de ser submetida à revisão crítica (...). Se ela ignora as condições sociais, que também são as condições sob as quais toda ética deve ser apropriada, aquele éthos torna-se violento $^{346}$.

Butler irá diferenciar a questão da violência ética mostrando que o pensamento de Adorno marca

(...) o lugar do indivíduo existente e [o lugar do indivíduo] na tarefa necessária de se apropriar da moral, bem como de se opor às diferentes formas de violência ética. No entanto, coloca-se contra o erro da posição oposta, quando o 'eu' se compreende separado de suas condições sociais, quando é adotado como pura imediaticidade, arbitrária ou acidental, apartado de suas condições sociais e históricas - as quais, afinal de contas, constituem as condições gerais de seu próprio surgimento ${ }^{347}$.

\footnotetext{
${ }^{345}$ BUTLER, 2015, p. 23.

${ }^{346}$ Idem, p. 16.

${ }^{347}$ Ibid., p. 17.
} 
Ou seja, há uma diferença ética, um desvio da ética coletiva, no ato do eu que interpela o $t u$ na sua razão equivocada de se entender fora do contrato social que o constitui como indivíduo. Butler, assim irá compreender esse gesto como um esquecimento de que nenhum eu indivíduo, eticamente, pode se separar das condições sociais de seu surgimento. Nenhum eu "tem história própria que não seja também a história de uma relação - conjunto de relações - para com um conjunto de normas"348. As consequências dessa noção de "despossessão do eu", nas palavras da autora, não significa, porém, que "tenhamos perdido o fundamento subjetivo da ética" ${ }^{349}$. Ao contrário, Butler quer marcar no seu pensamento que há uma outra maneira de entender a questão da moral e da ética desde o dispositivo de interpelação. Isto é, quando um eu interpela o $t u$, só o faz já incorporando o $t u$ desde a língua. Isso significa dizer também que tal incorporação desde a "despossessão do eu" só é possível de ser feita se o indivíduo que interpela aceita que já faz parte da regra social que ao mesmo tempo deseja violentamente afastar pela interpelação do tu. Aquele que interpela um $t u$ como baderneiro — "ei, tu, baderneiro!" - somente o faz acolhendo o outro em si, na sua despossessão de si, ou seja, já encena a baderna em seu si despossuído. Quem diz "tu, baderneiro" performa, incorporando na linguagem a baderna; performa a baderna como sujeito capaz de dizer “eu, tu e nós”, numa mesma língua.

Nessa esteira, com o pensamento de Butler, o eu performa o fora de si aceitando o diante do outro como uma lei, um incondicional a sua ipseidade. $\mathrm{O} e u$ só pode dizer-se como tal - como um "eu não sou baderneiro" ou "eu não sou um voyou" - se for para responder a um outro, perdendo a posse de si, desde a partida. Como afirma Butler:

(...) dou relato de mim para alguém, e o destinatário desse relato, real ou imaginário, também interrompe a sensação de que esse relato é de fato meu. Se dou um relato de mim mesma para alguém, sou obrigada a revelá-lo, cedê-lo, dispor-me dele no momento em que o estabeleço como meu. É impossível fazer um relato de si mesmo fora da estrutura de interpelação, mesmo que o interpelado continue implícito e sem nome, anônimo, indefinido. A interpelação é que define o relato que se faz de si mesmo, e este só se completa quando é efetivamente extraído e expropriado do domínio daquilo que é meu. É somente na

\footnotetext{
${ }^{348}$ Ibid., p. 18.

${ }^{349}$ Idem.
} 
despossessão que posso fazer e faço qualquer relato de mim mesma. ${ }^{350}$

A despossessão do eu de Butler (2015), porém, não significa um fracasso da ética. Ao contrário, nos diz que "o relato que faço de mim mesma é parcial, assombrado por algo para o qual não posso conceber uma história definitiva" ${ }^{\circledR 51}$. Ou seja, tal pensamento nos convoca a analisar a questão da responsabilidade e do éthos coletivo sem que caiamos numa totalidade reconciliadora. Butler observa que o éthos coletivo é violento desde a sua enunciação. A participação e tomada de posições entre os sujeitos no debate da pólis reserva uma condição violenta na ipseidade da língua.

Para além da espiral da questão da língua que já vimos com Derrida como um paradoxo de sentir-se em casa e nunca ser-lhe próprio - do outro e ao outro enviada ${ }^{352}$ —, a interpelação “tu, baderneiro!” nos conduz ainda a pensar outra iterabilidade que põe a baderna na economia circular e narrativa: ela, baderna, como um espectro, é chamada desde sempre, na rua, na espacialidade do encontro/confronto das tensões de um comum partilhado. Esse outro, baderneiro, que pode ser interpelado como um fora de si, um fora da lei - alegorias reincidentes do apolitico, da besta, desse outro é preciso manter distância, marcando-o bem para lá. Tu, baderneiro, para lá - “Dis-tanz!", um indecidível derridiano que nos reconecta outra vez com a dança e que pode nos ajudar a pensar a questão ético-política da alteridade no espaço democrático.

Há dois momentos suplementares na desconstrução derridiana que podem nos ajudar a pensar tal gesto.

Em Esporas (2013), Derrida irá nos lembrar do jogo nietzschiano sobre o gesto filosófico de evitação da verdade, que é a não verdade de toda verdade, a impossibilidade de um retorno a si de qualquer verdade, que, na sua leitura, é o sentido de mulher nietzschiano. A mulher seduz tal como a verdade, diria

\footnotetext{
${ }^{350}$ Idem., pp. 51-52.

${ }^{351}$ Ibid., p. 55.

${ }^{352}$ DERRIDA, $2001 \mathrm{~b}$.
} 
Nietzsche. "A mulher e suas operações a distância" "353, e, por sua vez, dessas operações é preciso manter distância.

Para se pensar o revezamento entre mulher e verdade, Derrida cita duas passagens de Nietzsche em A Gaia Ciência (1882), como um conselho nietzschiano dado aos homens, um certo nós que veremos ecoar nas suas palavras. Um nós da filosofia, "nós, os homens da filosofia" — poderíamos incluir no trecho abaixo. Acompanhemos:

Se amamos uma mulher, imediatamente o espírito e a força do sonho vêm sobre nós e, de olhos abertos e indiferentes ao perigo, escalamos os mais perigosos caminhos, rumo aos telhados e torres da fantasia (Phantasterei), sem qualquer vertigem, como que nascidos para escalar - nós, sonâmbulos diurnos (wir Nachtwandler des Tages)! Nós, os artistas! Nós, o ocultadores do que é natural (wir Verhehler der Natürlichkeit)! Nós, maníacos da Lua e de Deus (wir Mond- und Gottsüchtigen)! Nós, incansáveis e silenciosos andarilhos (wir totenstillen, unermüdlichen Wanderer), em alturas que não vemos como alturas, mas como nossas planícies, nossas certezas!

Porém, meu nobre sonhador, porém! Mesmo no mais belo veleiro há muito ruído e alarido (Lärm) e, infelizmente, muito alarido pequeno e lamentável (kleinen erbämlichen Lärm)! O encantador e poderoso efeito das mulheres (der Zauber und die mächtigse Wirkung der Frauen) é, para usar a linguagem dos filósofos, um efeito a distância (de la faire sentir au loin, eine Wirkung in die Ferne, uma operação a distância), uma actio in distans: o que requer, antes e acima de tudo - distância! (dazu gehört aber, zuerst und vor allem - Distanz!) $)^{354}$.

Derrida, por sua vez, jogará ainda com a palavra distanz, distância em alemão, que arquiva, desde a sua marca, um rastro de dança [tanz, em alemão]. "Dis-tanz!", grafa Derrida, abrindo, assim, um afastamento no pensamento nietzschiano, fazendo-o dançar, dar uma pirueta, jogando com o seu próprio estilo (as esporas de Nietzsche). Acompanhemos agora Derrida:

Sobre qual passo se abre esta Dis-tanz? A escritura de Nietzsche já a mimetiza, graças a um efeito de estilo desviado entre a citação latina (actio in distans), parodiando a linguagem dos filósofos, $e$ o ponto de exclamação, o hífen que deixa em

\footnotetext{
${ }^{353}$ NIETZSCHE, 1882 apud DERRIDA, 2013, p. 26.

${ }^{354}$ NIETZSCHE apud Derrida, 2013, pp. 29-30.
} 
suspenso a palavra Distanz: que nos convida, por uma pirueta ou um jogo de silhueta, a nos mantermos longe destes múltiplos véus que nos produzem sonho mortal ${ }^{355}$.

A espora do hífen em Dis-tanz marca uma diferença em relação à mulher pensada por Nietzsche, já incorporando o seu rastro. Para manter a distância de um discurso ontológico do lugar da mulher na filosofia como uma operação a distância que em algum momento pode significar uma advertência para ela, como um: "mantenha-se a distância". Derrida alerta: "o filósofo que crê nesta verdade que é mulher, crédulo e dogmático, que crê tanto na verdade quanto na mulher, não entendeu nada. Não entendeu nada nem de verdade nem de mulher"356. A não identidade, ou mulher, a não identificação, não atribuição de um lugar para a mulher é a posição radical da distância, sua Dis-tanz, que assume Derrida. Os giros são múltiplos nessa posição. Uma vertigem contraditória que resiste a qualquer elaboração "datada" de um discurso sobre "a mulher".

(...) é porque "a mulher" não é, talvez [e o talvez inscrito aqui é uma oscilação necessária], alguma coisa, a identidade determinável de uma figura que se anuncia à distância, à distância de outra coisa, e da qual teria que se afastar ou se aproximar. Talvez seja ela, como não identidade, não figura, simulacro, o abismo da distância, o distanciamento da distância, o corte do espaçamento, a distância mesma, se ainda pudesse dizer, o que é impossível, a distância mesma ${ }^{357}$.

As consequências desse pensamento são radicais para a elaboração de qualquer verdade sobre o feminino, a mulher, bem como da verdade do lugar da mulher.

II.

Num segundo momento, em Choreographies (1994), em entrevista a Christie V. McDonald, Derrida retoma a Dis-tanz para, outra vez, manter uma radical distância de qualquer ontologização de um lugar para a mulher, portanto

\footnotetext{
${ }^{355}$ DERRIDA, 2013, p. 31. [Grifos do autor]

${ }^{356}$ Idem., p. 33.

${ }^{357}$ Idem., p. 32. [Grifos do autor]
} 
da constituição de uma pauta ou horizonte para a luta feminista. Derrida quer pensar aí uma revolução que advém do movimento de mulheres para além da conquista e da administração de direitos. A entrevista começa com uma introdução de McDonald sobre Emma Goldman, feminista do século XIX que, segundo lembra a interlocutora, era admiradora da inovação e rebeldia nietzschiana, que proclamava "a revolução como pensamento em ação". É celebre a fala de Goldman em resposta ao movimento feminista de seu tempo, retomada por McDonald: "Se eu não posso dançar, eu não quero fazer parte de sua revolução". McDonald salta da citação de Goldman para a primeira pergunta ao filósofo com um "como você descreveria o lugar da mulher"358? Por conta do seu pensamento de Dis-tanz radical, mencionado acima, Derrida, estrategicamente, desenhou múltiplas coreografias para responder sem dar a resposta de qual seria o women's place.

Não farei uma análise detalhada do diálogo entre McDonald e Derrida para podermos pegar, mais rapidamente, o atalho entre Dis-tanz e baderna que no interessa aqui. Estrategicamente, tentarei ir direto, se possível, justamente [usando esses termos ainda sob rasura: fight tolright at), às passagens que nos ajudaram a pensar a perigosa dupla mulher e dança, posicionada por Derrida como uma difícil operação que não se submete à preocupação regular e reguladora que a arquitopo-economia do discurso telecoreografa na pergunta de McDonald. Vamos para outro problema elaborado por Derrida. Saltemos.

Derrida escreve em Chorégraphies (1992):

A mais inocente das danças já contraria toda atribuição de uma residência, escapa a essas residências sob vigilância; a dança muda de lugar e acima de tudo muda os lugares. Em seu rastro, os lugares não podem ser mais reconhecidos. A alegre perturbação que o movimento de mulheres, e de algumas mulheres em particular, trazendo com ela a chance de uma certa turbulência arriscada na atribuição de lugares dentro do nosso pequeno espaço europeu (não falo de um abalo maior em vias de mundialização) não é uma possibilidade de alguma turbulência aleatória na atribuição desses lugares? ${ }^{359}$.

O problema encenado por Derrida e a referência ao pequeno espaço europeu aí dizem respeito à questão da herança falogocêntrica da tradição

\footnotetext{
${ }^{358}$ MCDONALD apud DERRIDA, 1992, p. 96. [Tradução minha.]

${ }^{359}$ DERRIDA, 1992, p. 100.
} 
filosófica ocidental que já telecoreografamos de muitas maneiras até aqui. Porém essa passagem, em especial, conecta de maneira mais efetiva, feliz, a dança à resistência ao arquétipo da figura masculina hegemônica na tradição ocidental, o sujeito-homem-branco-europeu-soberano, desde o princípio arcôntico, ou, ainda, desde Homero, endereçado ao retorno à casa, chez-soi, ao si mesmo, ao poder da consciência sobre si. Um afastamento sutil e certeiro de uma Dis-tanz radical se anuncia no pensamento de dança, improvisado, de Derrida ${ }^{360}$. Dis-tanz!, ecoa na passagem acima, marcando também que o pequeno espaço europeu deve ser lido, sobretudo, como um espaço domiciliar vigiado pela normatização sexual e suas telecoreografias de tratados e discursos topo-econômicos.

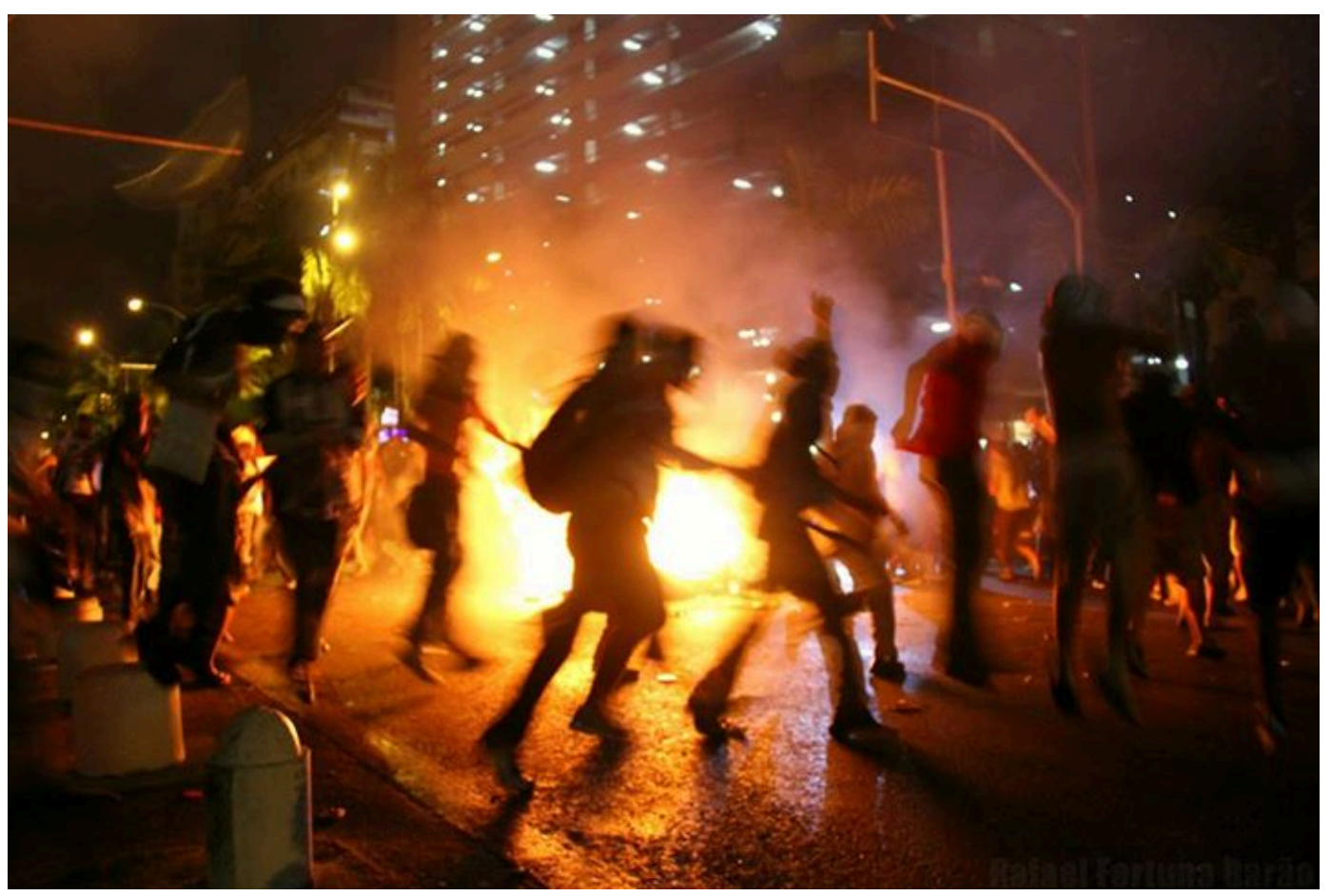

A Batalha da Alerj - Manifestações de Junho de 2013 no Rio de Janeiro.

Foto: Rafael Fortuna Barão, 2013.

Mais adiante, Derrida ainda põe em discussão esse movimento turbulento que pode gerar uma ambiguidade perigosa. Vejamos:

\footnotetext{
${ }^{360}$ É importante lembrar que Derrida inicia o diálogo com McDonald pedindo permissão para improvisar nas suas respostas, dizendo assim que essa será sua homenagem à dança. Diz Derrida: "Joguemos com a surpresa, será nossa homenagem à dança: ela só deve ter lugar uma vez, ela não demora nem se afunda, sobretudo ela não se arrasta depois de seu tempo. Nós não nos deixaremos voltar, portanto, não é o momento para voltar também, ou até mesmo para olhar com cuidado, somente um entrever" (DERRIDA, 1992, p. 96).
} 
A grande dificuldade é a necessidade de entregar a dança, o tempo da dança, à "revolução" [as aspas suspendem e colocam o termo sob rasura]. A atopia ou loucura da dança [l'atopie ou la folie de la danse] de certa maneira também pode comprometer as hipóteses políticas e servir como um álibi para abandonar as lutas "feministas" organizadas, pacientes, laboriosas, em contato com toda a resistência que um movimento de dança não pode dar, embora dança não seja sinônimo nem de impotência nem de fragilidade ${ }^{361}$.

Uma revolução dançante, como uma entrega radical à dança, é duplamente perigosa. Uma questão de espaço-tempo: por um lado, o apelo à entrega da dança pode criar uma turbulência topológica; por outro lado, devido à sua intempestividade [l'atopie ou la folie de la danse], pode comprometer hipóteses políticas e também ser um álibi para abandonar as lutas. É preciso pensar com cuidado essa segunda afirmação para que não se capitalize em Derrida um pensamento alérgico às formas de organização e seu levante político - sim, eu disse alérgico, tentando provocar uma fratura e, ao mesmo tempo, salvar a tradução para o português de "l'atopie", termo que Derrida não esclarece, usa-o sem explicá-lo, e por isso terei que arriscar uma proposição estratégica.

Atopia, na medicina, é, incidentalmente, em português, o termo utilizado para se referir à predisposição imunológica hereditária de desenvolver anticorpos contra alérgenos ambientais. Esse termo, portanto, arquiva o sinônimo de alergia. Coceira, irritação na pele, asma; intolerância biológica hereditária predisposição familiar à intolerância. Porém não é a essa atopie que Derrida está se referindo. De certa maneira, acredito que l'atopie de la danse lançada por Derrida é alérgica a essa outra atopie imunitária. A atopia da dança, que é também uma folie [que se traduz facilmente por loucura, mas que também arquiva uma cadeia etimológica entre fole, fôlego e folia], me parece remeter mais a uma noção de sem-topia, sem topos, o escape do horizonte. Tal folia constrói o chão, o suporte da dança, sem que este seja sinônimo de ancoragem imobilizante, um encalhamento ou um pouso repousante.

Derrida, certamente, está retomando a experiência socrática. Dirá Sócrates de si mesmo no diálogo Teeteto: "Eu sou totalmente átopos e não crio senão aporia" (149a). Átopos [que pode ser traduzido como o estranho, o

${ }^{361}$ DERRIDA, 1992, p. 100, comentários meus. 
esquisito, o inconveniente, o absurdo, o deslocado, o descabido, o sem lugar, o fora de si, entre outros] $]^{362}$, retorna em Derrida para pensar a ipseidade do tempo da dança. O tempo para um fôlego, um levante de salto, uma saída do chão sem horizonte. Justamente no tempo quando se perde o horizonte na vertigem entre o saltar e o cair [é preciso chão para poder cair]. Um tempo fora de si, pathos out of joint. Uma loucura dissimétrica entre muitas línguas, uma torção entre elas. [Quantas línguas precisarei invocar e retorcer para traduzir e fazer justiça à força dessa atópica folia, desse outro tempo-espaço da dança que nos lançou Derrida? Terá sido esse o lançamento, a revolução dançante pensada por Derrida, ou já estou imprimindo demasiadas forças em seu nome? Retomemos.]

A atopia ou a loucura da dança é a de se manter sempre em distância, sempre já de partida do chão, do território, do fundamento. Uma passagem de Esporas (2013) pode nos ajudar a entender o jeito/estilo singular de se manter a distância, de se proteger do repouso:

(...) o estilo pode também, com sua espora, se proteger contra a ameaça terrificante, cega e mortal (do) que se apresenta, se dá a ver com teimosia: a presença, portanto, o conteúdo, a coisa mesma, o sentido, a verdade - a menos que isso não seja já o abismo deflorado em todo este desvelamento da diferença. Já, nome disso que se apaga ou, antecipadamente, se subtrai, deixando, contudo, uma marca, uma assinatura subtraída naquilo mesmo do que se retira - o aqui presente - e do que portanto teria que ser levado em conta ${ }^{363}$.

A dança se dá, já escapando. Apesar de tocar e espetar como uma espora [para lá!], mantendo-se sempre a distância, essa atopia intempestiva não pode ser confundida com alergia ao outro tempo mais organizado, mais demorado. Quando Derrida chama a atenção para o risco do comprometimento de hipóteses e para a questão do álibi e do abandono de lutas, em nenhum momento está se colocando contra os que se organizam, tomam tempo que é outro diferente dessa dança atópica. A atopia da dança não é alérgica a hipóteses, cálculos, estratégias e lutas. A atopia de que se fala aqui é a da revolução das posições, como revolução por vir

\footnotetext{
${ }^{362}$ Há ainda muitas passagens em nos diálogos do Banquete, Fédon, Fedro e Timeu em que átopos vagueia dubiamente por diversos sentidos e traduções. Derrida certamente está se valendo dessa herança incerta, desse deslocamento de lugares, para pensar o problema da dança e da revolução. [Agradeço a Luisa Severo Buarque de Holanda que me atentou a essa tributação de Derrida a Sócrates.]

${ }^{363}$ DERRIDA, 2013, pp. 24-25. [Grifos de Derrida]
} 
das hipóteses, dos cálculos, das estratégias e das lutas. Não se refere, porém, à mudança de um lado para o outro, de uma luta para outra, de posição em posição. "Em sentido bastante rigoroso, a mudança ela mesma (...) não seria ainda suficiente, porque o desejo continuaria a escapar de uma única combinação e inventaria coreografias incalculáveis" "364. O desafio é "se entregar ao tempo da dança", diríamos, assumindo o risco dessa entrega incessante e também irremediável de fazer coreografias incalculáveis.

A atopia dançante [baderna?] demanda uma predisposição de difícil duração: não há como permanecer nela, não há como permanecer na sua força de turbulência radical que, por um lado, faz tremer a arqui-topo-economia da tradição patriarcal, trocar de hipóteses, reposicionar os espaços domiciliados; e, por outro lado, é também uma alegre perturbação, um jogo, uma folia. L'atopie ou la folie de la danse, no seu movimento de ação em distância [Dis-tanz], não dá um horizonte. E tal condição, Derrida alerta, não é sinônimo "nem de impotência nem de fragilidade". Ela gera um compromisso impossível e necessário a tal revolução/pensamento dançante, que Derrida descreve como: “(...) uma negociação incessante, cotidiana - individual ou não - às vezes microscópica, às vezes cadenciada como cartadas [coups de poker]; sempre privada de segurança, seja na vida privada ou nas instituições" ${ }^{365}$.

A turbulência da Dis-tanz de Derrida pode nos ajudar a refletir sobre a mobilidade da baderna como pensamento/ação em revolução que desafia a arquitopologia do político no social contemporâneo. Dist-tanz!: Baderna! A baderna não tem lugar; ela incide na própria distância dos lugares, na impossibilidade de se assentar plenamente os lugares. No espaço urbano, a baderna faz a pavimentação tremer, racha os espaços prontos para ser bem ocupados, ordeiramente ocupados. E talvez a afinidade entre baderna e as insurgências dissidentes, sobretudo as formas de organização cada vez mais descentralizadas, não sejam mera coincidência.

\footnotetext{
${ }^{364}$ DERRIDA, 1992, p. 115.

${ }^{365}$ Idem.
} 
Convém destacar uma passagem de Butler, em seu ensaio Bodies in Alliance and the Politics of the Street (2011), publicado logo no primeiro ano das insurgências no Oriente Médio que ficaram conhecidas como Primavera Árabe. A leitura de Butler, talvez, nos ajudará a pensar o esporão que rompe e abre rachaduras no duro e terraplanado solo do espaço urbano que se agita com a chegada dos movimentos que fazem a pólis dançar. [Peço licença, mais uma vez, para fazer uma longa citação, pois ainda sofro do mal de não saber ao certo o justo corte de uma citação.]

Butler escreve:

Nos últimos meses têm havido, de tempos em tempos, manifestações de massa na rua, na praça, que são muitas vezes motivadas por diferentes propósitos políticos, e algo de similar acontece: corpos se reúnem, eles se movem e falam juntos e reivindicam um certo espaço como espaço público. Agora, seria mais fácil dizer que essas manifestações ou, de fato, esses movimentos são caracterizadas por corpos que se juntam para fazer uma reivindicação no espaço público. Porém essa formulação pressupõe que o espaço público está dado, que já é público e que é reconhecido como tal. Nós perderemos alguma coisa da questão das manifestações públicas se deixarmos de ver que o caráter mais público do espaço está sendo disputado e até mesmo lutado quando essas multidões se reúnem. Assim, embora esses movimentos tenham dependido da existência prévia de pavimentação [pavement], rua e praça, e muitas vezes apenas reunidos em praças, como em Tahrir, cuja história política é potente, é igualmente verdade que as ações coletivas reúnem o próprio espaço, juntam o pavimento, animam e organizam a arquitetura. Por mais que devamos insistir na existência de condições materiais para a assembleia pública e o discurso público, também temos de perguntar como assembleia e discurso reconfiguram a materialidade do espaço público e produzem ou reproduzem o caráter público daquele ambiente material. E, quando multidões movem-se fora da praça ["outside the square", diz Butler, que poderíamos também traduzir por fora da ordem/fora do perímetro e assim forçar uma via tortuosa de tradução desse pensamento como baderna], para a rua ao lado ou para a viela ao redor, para os bairros onde ruas ainda não estão sequer pavimentadas, algo a mais acontece. Nesse momento, a política não é mais definida como atividade exclusiva da esfera pública distinta de um privado, mas cruza essa linha outra vez e chama a atenção para a maneira que a política já está em casa, ou na rua, ou na vizinhança, ou mesmo 
nesses espaços virtuais que não são presos pela arquitetura da praça pública ${ }^{366}$.

Poderíamos traduzir "outside the square" como fora da praça, fora da ordem, fora do perímetro. Nessa negatividade distante dos espaços em movimento, os corpos que ativam e animam a cidade badernam o local público fazendo o chão tremer. A baderna é trans-territorial e também migrante. Deslocase de um lugar para o outro. Movimento oblíquo de múltiplos afastamentos que telecoreografa arquiteturas outside the square, abalando a terrificação reguladora dos movimentos de corpos na pólis. No fôlego de sua atopia, no tempo do seu já [right now!, diríamos na língua do outro $\left.{ }^{367}\right]$, na vertigem de um salto - entre o levante e a queda sem horizonte - , de um lado para outro, a baderna, aqui-eagora, abre rachaduras sobre a superfície, provoca fissuras, desníveis, interrupções na sua mudança de lugares. Encena a própria revolução dos lugares, ou melhor, a impossibilidade de se deixar capitalizar o movimento e a alteridade dos corpos em movimento numa arquiorigem simples ou banco de depósito seminativo. Baderna, subjetilmente, aqui-e-agora, [enviaria em múltiplos lances] acaba de encenar uma fugitividade transmigratória e disseminativa [para acabar, de uma vez por todas, com qualquer juízo do logos, sem sofrer nem de pai nem de mãe $\left.e^{368}\right]$ : "É preciso ir para a rua dançando!", nos diria seu espectro.

Desde a imigração de Maria Baderna, da Itália para o Brasil, que ela teve seu nome associado à sublimidade do romantismo (auge e decadência) no balé brasileiro. Um nome de uma bailarina [e aqui grifo o gênero] assumiu a forma interpelativa [o "tu, baderneiro" para os "homens cabeludos demais, os contestadores, os revolucionários, os apóstolos da revolução sexual” e depois para os “criminosos, vândalos, arruaceiros..."], oportunizando nessa outra escrita um espaçamento e uma viagem entre ruas, chãos e fronteiras [de língua, de estado e de movimentos]; a iterabilidade da baderna evoca um espectro de dança [l'atopie

\footnotetext{
${ }^{366}$ BUTLER, J. Bodies in Alliance and the Politics of the Street, 2011. Texto disponível em: $<<$ http://www.eipcp.net/transversal/1011/butler/en>>, último acesso: em ago. 2016. [Comentários meus]

${ }^{367}$ Gostaria de deixar ecoar, espectralmente, uma das palavras de ordem do movimento Black Lives Matter, que reencenei algumas vezes nas minhas saídas à rua na terra do outro e que na sua língua cria um ritmo avassalador. Deixem ecoar em vocês também: "What do you want? Justice! When do you want it? Now!" [O que vocês querem? Justiça! Quando vocês querem? Agora!].

${ }^{368}$ Deixo ecoar a subjetilidade entre Artaud e Derrida que pensei em outro lugar [Cf. Andrade, 2013a]. Mas esse eco de agora é já outro, encena outra força.
} 
et la folie de seu tempo]. Num movimento acidental, disseminativo e vertiginoso, baderna põe a dança na pólis contemporânea não mais como uma alegoria, mas, sim, como força sempre por vir, uma força fraca [no sentido que já pensamos anteriormente] que toma as ruas reativando o público, justamente ali onde os desajustes não mais podemos remediar; ali, onde e quando o incondicional estarcom persiste ainda como disjuntivo.

$\mathrm{Na}$ rua, a badernagem ${ }^{369}$ agita a cidade fazendo-a dançar como uma democracia por vir, conjurando o espaço público, a res publica, como acolhimento radical do contraditório. Mas, sim, ainda perigosa. Baderna encena uma orquestração perigosa entre regimes espaciais, sujeitos, homens de leis, índios, vândalos, arruaceiros, não cidadãos e aqueles que não têm casa, nem quarto, nem são dignos de tal. Rogues, voyous, schurke, baderneiros, vadias, vadios, putas, canallas, patifes, salafrários, bandidos, degenerados, delinquentes, lobos, leviatãs, desplazados, rapscallions, arruaceiros, brigands - quem de direito pode interpelar esses gestos que circulam e circundam os limites da cidade, dos cidadãos e dos não cidadãos, dos estrangeiros e dos imigrantes, dos amigos, dos não amigos e dos inimigos, do hospedeiro, hóspede e hostil? A resposta para essa pergunta não pode repousar em nenhum lugar; preciso de múltiplas telecoreografias para continuar a persegui-la.

A badernagem performa a insurgência radical político, nos dizendo que é preciso dizer sim, sim à democracia por vir que Derrida pensou "como sentido à espera, ainda vazio ou em vacância da palavra ou do conceito de democracia» ${ }^{\text {370 }}$.

\footnotetext{
${ }^{369}$ Seria mais apropriado dizer badernocracia e assim forçar uma tradução para voyoucratie no lugar de vadiocracia? Ou estarei falando de uma disjunção de força muito local? Diz Derrida [na tradução de Bernardo]: "a vadiocracia é também um poder corrompido e corruptor da rua, poder ilegal e fora da lei que reagrupa em regime vadiocrático, e portando em formação organizada e mais ou menos clandestina, em Estado virtual, todos quantos representam um princípio de desordem, não de caos anárquico mas de desordem estruturada, se assim posso dizer, de conspiração, de conjuração, de ofensa ou de ofensiva premeditada contra a ordem pública. Ou mesmo, dir-se-á, de terrorismo - nacional e internacional. A vadiocracia é decerto um princípio de desordem, a ameaça contra uma ordem pública, mas, como cracia, representa também mais do que vadios individuais ou individualistas - é o princípio da desordem enquanto ordem de suplementação (um pouco como uma sociedade secreta, uma ordem religiosa, uma seita ou um confraria análoga a qualquer franco-maçonaria). [...] A vadiocracia constitui já, institui mesmo uma espécie de contrapoder ou de contracidadania. É aquilo a que se chama um $<<$ meio >" (DERRIDA, 2009c, pp. 137-138). Esse meio de contrapoder e contracidadania, suplementar ao exercício de poder e de cidadania, é o que viemos pensando sobre o estado de baderna na cidade. Mas ainda não estou seguro de que podemos fazer tal transposição - entre a voyoucratie pensada por Derrida e a badernagem que estamos pensando com a dança. Talvez seja o rastro da dança que faça a baderna não assumir o lugar de uma voyoucratie.

${ }^{370}$ DERRIDA, 2009c, p. 52.
} 
A democracia por vir não reserva razão em si, demanda debate, excedendo, portanto, a soberania do mais forte.

No fim das contas, se tentarmos voltar à origem, não sabemos ainda o que terá querido dizer democracia. Porque democracia não se apresenta, não se apresentou ainda, mas isso [ça] vai vir. Enquanto se espera, não renunciemos a servi-nos de uma palavra cuja herança é inegável mas cujo sentido está ainda obscurecido, ofuscado, reservado. Nem a palavra nem a coisa "democracia" são ainda apresentáveis. Não sabemos ainda o que herdamos, legatários que somos desta palavra dita grega e daquilo a que ela nos consigna, nos ordena, nos lega ou nos delega. Somos inegavelmente legatários, ou mesmo delegados desta palavra e dizemos "nós", aqui, enquanto legatários ou delegados desta palavra que nos foi enviada, endereçada desde séculos, e que nós sempre reenviamos para mais tarde. Bem que há alegações de democracia por todo lado, entre "nós"; mas nós próprios estamos sem saber o sentido deste legado, a missão, a emissão ou a comissão desta palavra ou a legitimidade desta alegação. O legado e a alegação e a leitura da legenda (joguemos aqui entre legare e legere) não fazem senão reenviar para mais tarde ou para algures. Este reenvio [renvoi] não acena para o passado de uma herança senão restando por vir. ${ }^{371}$

A democracia enquanto herança não se trata de um cumprimento de agenda. Há, sim, retornos à democracia, eternas circunlocuções sobre essa palavra a qual trabalhamos, tomamos parte e somos delegados. Mas há também um estado de espera e promessa irredutível que se constrói, incondicionalmente, na insistência sobre o dissenso, o debate, a diferença, a heterogeneidade das mediações e alteridade também irredutível que sempre escapa. A coletividade da democracia sempre por vir não tem a ver com submissão a uma força, nem mesmo com o exercer da força de uma palavra reguladora, mas sim é o estar-empúblico. Esse meio-aos-outros é a própria força que engata a circularidade das partilhas do comum.

Pois bem, a democracia seria isto, a saber, uma força (kratos), uma força determinada como autoridade soberana (kurius ou kuros, poder de decidir, de cortar, de prevalecer, de levar de vencida e de dar força de lei, kuroo), logo o poder e a ipseidade do povo (demos). Esta soberania é uma circularidade, ou mesmo uma esfericidade. A soberania é redonda, ela é um arredondamento. Esta rotação circular ou esférica, a volta desse re-torno a si pode tomar a forma alternante do à-vez [tour à tour], do cada um na sua vez, por seu turno, como a da

${ }^{371}$ DERRIDA, 2009c, p. 52-53. 
identidade entre a origem e o termo, a causa e o fim, a causa motriz e causa final. ${ }^{372}$

Ou seja, aquilo que chamamos de estado democrático demanda a partilha, a circularidade e o plus d'une [mais de um/ basta de um] que não autorizam nenhuma parte decidir por todos. Lidar com a democracia é manter assim o debate entre as partes não para afirmação de um consenso, mas sim para manter a esfericidade que é estar entre muitos.

A badernagem do estar na rua, do poder ser furtado na rua, de perder a sua propriedade pela tomada do outro, mesmo que por uma interpelação, por sua saída-de-corpo ao público, também nos deixa escapar que toda ativação de uma telecoreografia se dá no porvir do democrático. É no agenciamento irredutível de corpos (humanos e não humanos, dos de agora e de outro tempo; das impressões, dos ecos e também dos espectros) que a pólis e o debate se põem em marcha e, por que não dizer, em dança.

[... mas não podemos esquecer o tu dissimétrico que acompanha uma certa baderna; é preciso ainda pensar o tu]

Uma última divisibilidade, então, da baderna já de partida. Retornemos à partida de um lugar inicial: Rio de Janeiro, Brasil. Farei saltos telegráficos para finalizar.

Saltemos, primeiramente, para a ano de 2013, quando a baderna, que seguia uma cadeia interpelativa entre "vândalos", "vagabundos", "arruaceiros", para além do enceguecimento causado pelo monopólio das mídias no Brasil, era sempre associada aos que "não entendem a causa", aos que "não nos representam" e aos que enfraquecem o movimento político pacífico. Apesar de esses movimentos dissidentes, cada vez mais recorrentes em diversos países, serem organizados pelo dinamismo disperso das redes sociais, articuladas pela internet, há sempre um certo nós que apela a um éthos violento ${ }^{373}$ para definir os modos de associação política: “- aqueles que estão aqui, juntos, pacificamente, são meus amigos, me representam. Todos aqueles, baderneiros, sem causa, vândalos, perdidos pela multidão, não me representam, não são capazes de compor uma

\footnotetext{
${ }^{372}$ Ibid, p. 58.

${ }^{373}$ BUTLER, 2005.
} 
força, não servem ao tal movimento mais importante e pacífico. Estes últimos são meus inimigos, os loucos, os fora de si, os fora da lei, que não conseguem se sujeitar à lei, a ter que ter uma lei. Resta-nos esclarecê-los, reintegrá-los ao nós ou rechaçá-los, expurgá-los, vê-los rodar na roda”.

Saltemos, outra vez, para o ano de 2016, quando as ruas das capitais brasileiras foram tomadas por movimentos pró-impeachment do governo da presidenta Dilma Rousseff. O termo baderneiro voltou novamente à cena de interpelação reguladora ainda mais diretamente direcionado àqueles contrários ao movimento autointitulado "contra a corrupção". No dia anterior à massiva manifestação do dia 13 de março de 2016, que, diferentemente das manifestações de junho de 2013, contou com amplo apoio dos partidos de extrema direita do País e das grandes mídias corporativas - não esqueçamos que $70 \%$ dos meios de comunicação no Brasil concentram-se na mão de seis famílias —, um subcomandante da Polícia Militar de Goiânia, o tenente-coronel Enrickson de Souza Lima, foi a uma rádio local convocar a população a tomar as ruas de forma "ordeira e pacífica",374. O subcomandante goiano garantiu a segurança desses “ordeiros e pacíficos" em detrimento daqueles "que se sentem no direito de não deixar que as pessoas de bem desse país possam protestar", que seriam combatidos fortemente pelas tropas de choque. Ele alertou que, para aquelas pessoas que "querem gerar baderna, bagunça e conflito, o nosso ditado: é pau e bomba. É essa a postura da tropa de choque". Nesse discurso, outra vez, a interpelação diz-sem-dizer: “baderneiros, para lá! Mantenham distância!”. Nessa reincorporação da distância, há uma desproporção de forças que opera para aniquilar a revolução do movimento dos corpos na cidade.

A iterabilidade desse performativo acusatório reencena o discurso do mais forte, de aspiração à soberania indivisível, que é sempre desproporcional. Interpelar "ei, você, baderneiro!" parte sempre de uma força desproporcional ${ }^{375}$. Esse "és tu um baderneiro" só pode partir de um eu, in/ex/corporado pela

\footnotetext{
374 Vídeo disponível em: < https://m.facebook.com/story.php?story_fbid=1543053816025107\&id=1410797609250729\&_rdr > . Último acesso em: 15 ago. 2016.

${ }^{375}$ Se houvesse tempo, traria a discussão de Lepecki em outro trabalho que me parece também incluir essa desproporção de forças dos movimentos na cidade, Coreopolítica e Coreopolícia (2012). Nesta tese, não o abordei para não nos marearmos em tantos outros giros. Mas me permitam, nestas últimas bordas do papel, nestes últimos tempos de escrita sobre a baderna, apenas mencionar esse outro trabalho de Lepecki como uma indicação de leitura, um suplemento que sussurra no canto de ouvido desta minha escrita [Cf. LEPECKI, 2012].
} 
ipseidade que funda a lei, já sendo, portanto, um lugar de fala e de direito fora da lei - a polícia, o Estado, a razão, as grandes corporações midiáticas e, também, o qualquer um que pode enquadrar o outro e exercitar o performativo, de uma só vez o tu e o nós. Essa desproporção de forças não gera estados de badernagem, mas, sim, e somente, estados de extermínio e fascismo ou, ainda, terrorismo de Estado.

A alteridade dos corpos que dançam dissidentemente na pólis, incapazes de restaurar qualquer moralismo sobre um discurso de cidadania como um homogêneo, "esta não cidadania de pessoas com as quais devemos nos preocupar, as quais devemos acolher, nos urge, nos compele a pensar numa relação democrática para além do Estado-nação"376. Agir com terrorismo de Estado, mandar caçar, prender com base em provas de crimes forjadas - além do poder interpelar o outro como rogue, vândalo, terrorista e baderneiro — aniquila qualquer chamado de democracia por vir.

Sem redenção, é preciso encerrar esta seção afirmando a tarefa de seguir refletindo insistentemente sobre o estado incondicional da mobilidade de corpos e de pavimentos como manutenção essencial da pólis. Ainda, talvez, e sem redenção, a singularidade do pensamento da baderna nos ajude a reformular a tarefa de agitação dos nós do estar-com-disjuntivo. E, por fim, e por um outro desvio, baderna pode redimensionar aquilo que chamamos de dança e do que pode vir como dança sem assim se proferir, como uma baderna que se dissemina para muito além de suas intenções, da restituição de sua biografia e das incursões históricas, pois, lembremos, nem mesmo Baderna, a Marietta Baderna, era de fato — ou, se preferirem, constativamente — uma baderneira.

\footnotetext{
${ }^{376}$ DERRIDA, 1997 apud BENNINGTON, 2004, p. 245.
} 


\section{6 \\ Navegações e Paragens: Filosofia Enlutada, Teorização Por Vir, Pensar em Não Ver}

"Quando um pensamento vem dançando" é uma das promessas arquivadas no título desta tese em marcha. Mais do que marcar uma afirmação, nossa travessia tem insistido no desafio de pensar um "quando", na sua oscilação espaço-temporal, um pensamento vem dançando. Essa espacialidade-de-tempo vem sendo trabalhada entre muitos suportes e paragens, muitos desvios, seção a seção, passo a passo, para dar uma abertura à performance do sim-ao-pensar na filosofia e na dança. Um exercício de evento por vir, razão por vir, democracia por vir! — num só lance, diria, quando, de uma vez por todas, e já no apelo da demora performado nesta escrita. E que tempo-espaço é esse, senão já um out of joint, que pensamos com Derrida? Que de-morar no tempo é esse já numa velocidade, no fôlego e na folia de um right now, de um direito agora, de um apelo desse momento já quase final? "De uma vez por todas", disse. Num só golpe e em múltiplos golpes. Múltiplos tempos a um só tempo, já sofrendo de partida e da partida.

É preciso partir e ir trabalhando o encalhamento e a encalhação de nossa travessia. Iremos logo mais para esse duplo evento singular que com Derrida poderemos pensar: "em vista do litoral (...) em vista ou longe da margem, sem chegada assegurada, entre terra e mar" ${ }^{, 377}$. Antes da chegada final, iremos nos demorar no momento de espera "entre" encalhamento e encalhação que performará um prólogo desta última seção antes da partida. Quero pensar esse "entre" singular quando os navegantes [que não são somente os tripulantes] temem a margem, sofrem de alguma aflição em vista do perigo de encalhar um barco, interromper o movimento cortante da proa sobre as águas, anunciando, assim, o precipício de uma travessia. Nesse "entre" em que se anuncia a chegada do evento por vir: do abismo do "quando depois" que vem sem poder se antecipar: à espera do "quando depois", como um antes de saltar do barco.

\footnotetext{
${ }^{377}$ DERRIDA, 2009c, p. 221.
} 
[Uma memória marítimo-biográfica me toma agora: registros de minha experiência com meu pai que retornam ao pensar a espera desse "quando depois". Ele, meu pai, que também se chama Sérgio, nos primeiros anos de sua juventude viveu como pescador, vindo de uma família formada por algumas gerações de pescadores e pescadoras, marisqueiros e marisqueiras, às margens das águas do Rio Paraguaçu, no interior da Bahia; ele também foi marinheiro e sempre trabalhou viajando entre terra e mar, entre muitas cidades, e ainda vive viajando, hoje, mesmo depois de aposentado, entre Salvador (minha terra natal) e Nagé (sua terra natal). Nunca aprendi sua habilidade de saber conjugar a força e as velocidades (mais de uma) necessárias para parar um barco, um veleiro, uma escuna, uma canoa, um saveiro, um bote. Naveguei com ele muitas vezes, sempre a passeio. Às vezes éramos tripulantes, às vezes passageiros. Ele talvez tenha tentado me ensinar um pouco de seu conhecimento incorporado no labor de ser pescador e marinheiro ou algo a respeito das paragens de um barco. Sim, ele deve ter realmente tentado, eu é que nunca aprendi muito bem. Navegamos sempre a passeio, não sozinhos, "eu e ele", mas também com minha mãe e minhas irmãs, com os amigos e as amigas, sobre muitos tipos de flutuantes em águas doces e salgadas, mares e rios. Muitas vezes navegamos, e talvez por isso ainda me lembro como se fosse hoje dos momentos em que a paragem do barco suscitava uma demorada sensação de espera. Uma certa aflição tomava conta de todos os navegantes nesse momento. Talvez pelos muitos cálculos de movimentos precisos que tinham de ser reencenados por todos/as, sem nos dar nenhuma garantia, mesmo com toda técnica possível de ser incorporada, aprendida e reiterada. Nesses singulares momentos de paragem, sempre havia o risco de mal encalhar a embarcação. Para cada tipo, uma coreografia distinta: para um lado ou para o outro, para a proa ou para a popa; segura uma corda, amarra outra, desliga o motor ou aciona o ponto morto (quando em barcos a motor); ou, ainda, apruma o remo na justa medida da lateral da canoa e "todos parados para não emborcar"; a vela, se houvesse, só se soltava depois de parado. "Algo assim" era sempre orquestrado, "não necessariamente nessa ordem" - como se diz a alguém quando não se tem certeza dos caminhos, do passo a passo de uma coreografia. Nunca aprendi bem a técnica de encalhar. Não seria capaz de capitanear tal expedição. Na experiência com meu pai, nas vezes em que ele era o capitão ou o remador, seguia as suas instruções, colaborava com o que podia, 
mas nunca acumulei dai nenhum conhecimento transmissivel. Somente guardei essa impressão de espera aflitiva que aqui relato. Alguma aflição da espera e também alguma nostalgia estranha em relação à viagem que já acabando e já de partida se iniciava aquando da espera para depois saltar de um barco.]

Antes de saltar do barco. Para falar do quando depois dessa paragem que chega por baixo no evento da encalhação/encalhamento, precisarei, primeiro, discutir o abismo abissal pensado por Derrida no ensaio $O$ "Mundo" das Luzes Por Vir $^{378}$. Seguirei com alguns gestos marítimos que cortarão um mar de metáforas importantes para se entender o apelo de uma agoridade demorada a que há pouco me referi como um golpe tríptico: evento por vir, razão por vir, democracia por vir — justamente aqui-agora neste espaço em que escrevo, em que teorizo enquanto escrevo. Por uma questão econômica, nestes últimos tempos da tese quase já de partida, será necessário marcar alguns desvios e cortes no texto de Derrida [e, desde já, peço desculpas ao leitor se tiver que cortar tantos atalhos e assim causar-lhe algum mareado] para chegarmos à discussão de se pensar o dizer sim à prática de uma teorização por vir ${ }^{379}$. Não farei, portanto, uma análise dos caminhos passo a passo do texto de Derrida. Farei um corte cirúrgico e estratégico.

Em O "Mundo" das Luzes Por Vir (Exceção, Cálculo e Soberania), Derrida se lança ao desafio mar aberto de pensar a tarefa, a honra e a finitude de um "salvar a honra da razão". Seu gesto de elaborar tal hipótese é, como ele chama, "abissal", justamente quando, nesse momento da história da humanidade,

\footnotetext{
${ }^{378} \mathrm{O}$ ensaio compõe a segunda parte do livro Vadios (2009). Cf. DERRIDA, 2009c.

${ }^{379}$ As razões desse seguir pensando uma teorização por vir irão se apresentar ao longo de toda esta seção da tese. Mas por ora, numa elipse, posso dizer que a abertura desse sim segue o mesmo método exorbitante que vimos performando até aqui. "É preciso começar de onde quer que estejamos: já num texto em que acreditamos estar", disse com Derrida, desde as Marcas Preliminares desta tese. Nesse sentido, o sim à abertura do pensar, o sim, sim ao pensar, precisa se deixar marcar desde o lugar de fala em que penso a democracia por vir: dentro da instituição acadêmica como doutorando em filosofia e como professor de dança de uma universidade pública. Ser professor de dança na minha atual trajetória reserva ainda uma singularidade: sou professor de um curso chamado de Teoria da Dança. Me deparo todos os dias com o problema de seguir pensando teorias ao mesmo tempo que venho pensando nesta tese as marcas violentas que a noção de teoria arquiva, a arquiviolítica da teoria. E, ainda, não me ocupo de qualquer teoria, mas, sobretudo, da difícil tarefa de teorizar a dança. Já estando neste texto fraturado, a promessa de uma teorização por vir é um imperativo que me toma por baixo. Me faz estremecer as bases. Eis a turbulência de que não consigo escapar e que me chama para o debate.
} 
após a revolução e a catástrofe do mundo tecnocientífico [da técnica, do cálculo, do controle, do arquidomínio, da contagem, da hybris, da desmesura...], o valor da razão, o desejo da razão e a dignidade da razão estão todos em xeque. Derrida parte então para pensar o "salvar a honra da razão" como uma hipótese.

Derrida escreve que “essa hipótese terrivelmente ambígua veio então, como deve fazê-lo qualquer hypothesis, colocar-se por baixo. Uma hipótese impôs-se por baixo daquilo que acabo de me ouvir dizer [salvar a honra da razão]"380. A hipótese derridiana "coloca-se por baixo", ele diz, e "impõe-se por baixo" como uma chegada. Escreve em seguida que "deslizando sob cada palavra, a hipótese abriu também um abismo sob cada um dos meus passos" ${ }^{381}$. A chegada que veio por debaixo abalou o suporte da hipótese, abriu um abismo sobre os pés de um tal pensamento de "salvar a honra da razão".

Esta hipótese abissal não me abandonará mais, mesmo se, no porvir, tenho de calá-la. Eis que estão aqui, repito-o, a primeira figura, o primeiro "se...": "E se fôssemos aqui chamados para salvar a honra da razão", ou se à hipótese se preferir a ficção do como se, do als ob honrado em filosofia, em nome da própria razão, várias vezes por Kant e por tantos outros, "seria como se fôssemos aqui chamados para salvar a honra da razão"? ${ }^{382}$

Ao usar essa metáfora da chegada do que vem por baixo como um abismo, que tiraria a certeza de qualquer caminhada segura para a execução de uma tarefa e também de uma rota segura, Derrida quer pensar a racionalidade de sua hipótese abissal como se pudesse pensá-la, perguntando-se se seria racional continuar a pensá-la ${ }^{383}$. Afinal, a responsabilidade de se pensar essa questão caberia a quem de direito? Aos homens da filosofia e tão somente a eles? Desde o seu nascimento, “com sua geografia e genealogia"? A quem e a que lugar restituir o problema da razão, para então podermos salvá-la de seu afundamento? Mas onde afinal teriam se afundado os caminhos da razão? Em que língua se poderia pensar tal questão? Essas são algumas perguntas que levam Derrida a refletir se ainda podemos salvar a razão de seu próprio abismo, fundado por ela mesma,

\footnotetext{
${ }^{380}$ DERRIDA, 2009c, p. 216. [Comentários meus].

${ }^{381}$ Idem.

${ }^{382}$ Idem.

${ }^{383}$ Derrida também elabora perguntas a esse respeito: “A honra da razão - será ela a razão? Será a honra razoável ou racional de parte a parte? (...) O valor da razão, o desejo de razão, a dignidade da razão - será tudo isto racional? Revela ainda isto, de parte a parte, da razão?" (DERRIDA, 2009c, p. 217).
} 
pelo excesso de uma certa razão, excesso de um certo cálculo da razão, jogando com a questão do quem de direito pode enunciar tal chamado desde a língua [questão, por sua vez, já abordada anteriormente quanto à ipseidade do eu posso desde o poder dizer $e u$ de um falante].

A questão da língua reaparece na hipótese abissal de Derrida devido à impossibilidade de se rastrear a força de nascimento da razão, lembrando que essa palavra, a razão, teria já navegado muitos mares e, portanto, nas mais diversas traduções arquivou em seu nome diferentes rotas. Afinal, fazer a travessia de tal responsabilidade, de se pensar a salvação da honra da razão, em nome de que/quem e a partir de que língua? - pensa Derrida, já desde o seu francês:

(...) [devemos] fazer em língua francesa, senão mesmo em nome da língua francesa, entenda-se numa língua europeia de ascendência latina mais do que grega ou germânica (reor quer dizer eu creio, eu penso, eu calculo, e ratio: a razão ou o cálculo, a contagem e a proporção), numa língua latina, logo já sobrecarregada de traduções, testemunhando assim por uma experiência da tradução que (...) toma a seu cargo todo o destino da razão, isto é, da universalidade mundial por vir? $?^{384}$

Com essa questão, Derrida oferece uma resistência a uma redenção messiânica a "um só deus" [como uma noção de salvação que vem do espectro heideggeriano, em Já Só um Deus Ainda Poderá nos Salvar ${ }^{385}$ ], que não

\footnotetext{
${ }^{384}$ DERRIDA, 2009c, p. 216.

${ }^{385}$ Precisarei fazer uma larga nota que correrá como em texto paralelo. Peço outra vez perdão e paciência para se seguir este largo desvio. Mas é preciso marcar que o pensamento de Derrida se coloca aquando "sem Um-Deus para nos salvar" - uma resposta penumbral do pensamento do filósofo franco-argelino em relação à entrevista de Heidegger concedida a Der Spiegel, publicada em 1976, sob o título de Já Só um Deus Pode Ainda nos Salvar, somente post-mortem ("seguindo o desejo, manifestado pelo filósofo ao concedê-la, de que aparecesse postumamente", diz a edição). Disse penumbral porque o aparecimento dessa resposta só pode ser pensado aquando numa experiência de perseguição de espectros, pois ela [a resposta penumbral] não se conjura numa visualidade direta e visível. Sofre do "efeito de viseira" do espectro, de assombrar sem se deixar ser visto [Cf. DERRIDA, 1994]. Digo resposta penumbral porque ela vem à borda da iluminação do espectro de Já Só um Deus Pode Ainda nos Salvar, na cegueira da luz vinda de um espectro, e resiste ainda na brancura da folha de papel, no espaçamento de $O$ "Mundo" das Luzes Por Vir. [Se possível, indicaria que o leitor lesse esses dois suplementos juntos para deixar vir, sem ver, os espectros que estou aqui conjurando. Só a partir desse "efeito de viseira" poderei dizer o que se segue.] Derrida nos convida a pensar outro já, outro já não podemos pensar (nem esperar, se de-morar) nesse "só um deus" heideggeriano, justamente para seguir acreditando (como uma fé naufrágica) e também em defesa incondicional de uma democracia por vir: gesto que requer trabalho de uma filosofia enlutada [a qual estamos pensando em paralelo, no texto paralelo a este que escrevo aqui na larga nota de pé de página que beirará já uma página inteira]. Em sua defesa incondicional à democracia, no seu apelo de fé naufrágica ("messianicidade sem messias", diremos mais adiante), sem garantias, como a bordo de um navio à beira de um naufrágio, a resposta penumbral de Derrida advém de muitos golpes do texto de Heidegger. Por uma questão
} 
responderia ao tempo abissal da chegada de sua hipótese terrivelmente ambígua. Uma chegada por baixo, apeladora do tempo de se demorar no já estando no jogo da razão, no seu suporte sem suporte, já não podendo mais se salvar desse abismo. Não há como nos salvar da indemnidade nem da imunidade da razão, dirá Derrida. Sua dívida e seu controle são incalculáveis, e talvez só nos resta pensar o incalculável desse cálculo. Insistir na incalculabilidade para de alguma maneira seguir pensando na racionalidade da razão, incondicionalmente, assim, não podendo abrir mão dela. Também são incalculáveis as traduções necessárias,

de tempo, e também de estilo, já assumindo que nunca teremos tempo suficiente para encerrar essas questões, permitam-me grifar algumas passagens no texto do filósofo alemão que nos abrem rotas para pensarmos os contragolpes dados pelo filósofo franco-argelino espectralmente [lembremos: em resposta a um texto post-mortem que não se dá no visível; uma resposta que sofre de "efeito de viseira"].

Heidegger (2009) diz: "Hoje, é para mim uma questão decisiva saber em que medida é que um sistema político (e qual) pode realmente ser conforme à era técnica. Não tenho nenhuma resposta para tal pergunta. Não estou convencido de que seja a democracia” (p. 26, grifo sublinhado meu). Também, mais adiante: "Se se me permite expressar-me com brevidade e até, de certo modo, brutalmente, embora com base numa longa reflexão, a filosofia não pode provocar nenhuma alteração imediata do atual estado do mundo. Isto não é válido apenas em relação à filosofia, mas também a todas as meditações e anseios meramente humanos. Já só um deus nos pode ainda salvar. Como única possibilidade, resta-nos preparar pelo pensamento e pela poesia uma disposição para o aparecer do deus ou para a ausência do deus em declínio; preparar a possibilidade de que [em vez de que, dito brutalmente, "estiquemos o pernil”] pereçamos perante o deus ausente" (p. 30, grifo sublinhado meu). Logo em seguida, Der Spiegel pergunta: "Há alguma conexão entre o seu pensamento e o advento (Heraufkunft) desse deus? Há aí, na sua maneira de ver, uma relação causal? Crê que nos podemos aproximar do deus pelo pensamento?". Heidegger responde: "Não o podemos atrair mediante o pensar. Podemos, quando muito, despertar a disposição a esperá-lo” (p. 30).

Pararemos por aqui nos rastreamentos dessa rota de resposta penumbral ao texto post-mortem de Heidegger. Na navegação particular que estamos traçando, cabe somente marcar o chamado de Derrida em defesa incondicional à democracia por vir, como evento por vir, por uma razão por vir, reafirmando justamente o plus d'une derridiano que precisa ser traduzido a um só lance "mais de um" e "basta de um". Ecoa de Derrida: o pensamento da democracia por vir apela ao plus d'une no sentido de que já não podemos esperar só-um-deus para nos salvar. Há uma temporalidade de espera nesse outro já que marco no pensamento derridiano, pois tal espera nos diz que não há $U m$ Deus e também não há nenhuma entidade reconciliadora a quem podemos nos reportar, nem "Deus, monarca, povo, Estado ou o Estado-nação", nem mesmo a "gaia-reconciliadora" pensada por Latour, não há instância alguma que possa nos salvar. O pensamento da hipótese abissal (que no devir de uma hipótese é também somente mais uma hipótese e, portanto, não a única hipótese possível; a hipótese abissal derridiana é impossível - já iremos pensar em paralelo) lançada por Derrida é um sim à espera, no sentido de uma fé incalculável, ou nas palavras do filósofo francoargelino: "fé hipercrítica, sem dogma e sem religião, irredutível a toda e qualquer instituição religiosa ou implicitamente teocrática. É aquilo a que noutro sítio [em Fé e Saber, nos lembra Bernardo] eu chamei a espera sem horizonte de uma messianicidade sem messianismo", diz Derrida (2009b, p. 268, comentários entre colchetes meus). Pensar tal hipótese abissal é impossível a uma só língua, a uma só filosofia, a uma só ipseidade. "Mais de um, basta de um", diz Derrida (2009b). O tempo-espaço dessa hipótese singular nos convoca a pensar outra vinda por vir. A vinda que vem da espera, à espera dessa fé naufrágica, apela à temporalidade do salut! saudação disjuntiva de chegada e saída partida, sem salvação. É na fé naufrágica dessa temporalidade disjuntiva que lanço as discussões que emanam ao longo da navegação desta tese: já agora [right to/right at] e quando depois, "de partida” [essa outra palavra que ecoa na vinda de um "salut"]! Retomemos. 
incalculáveis viagens marítimas, para seguir pensando qualquer "salvação de honra".

Com Derrida, a incalculabilidade torna-se um pensar de uma tarefa lançada e recebida por baixo, qualquer hipótese, como sempre por vir. Pensar qualquer hipótese encontra nesse gesto abissal uma ética inacabada e, portanto, apeladora de de-mora, de uma espera de tempo singular [da chegada] e de espaço singular [por baixo] do "como se" não houvesse horizonte, "como se" não houvesse a possibilidade de fazer frente a um horizonte, a um face a face. Derrida propõe, assim, um pensar da ética como hipótese abismal/abissal que se impõe, de chegada, como uma singular incalculabilidade que também é uma radicalização do cálculo. [ A quantas telecoreografias melancólicas você nos transporta, Derrida!] A atopia e a loucura do cálculo, diríamos, é uma condição incondicional para seguir pensando a razão por vir: de baixo, de chegada e já de partida.

Para tanto, é preciso ainda pensar a formulação da hipótese abissal lançada por Derrida, "deslizar sob cada palavra" ao "salvar a honra da razão". Observemos, primeiramente, que mais do que um apelo à razão ela mesma, Derrida nos convoca a pensar a salvação [salut] da "honra" da razão. Por sua vez, para entender a singularidade desse gesto, é preciso marcar a escolha da palavra salut nesse evento abissal que para Derrida, veremos, não é sinônimo de redenção. Derrida joga com a indecidibilidade do termo salut em francês, que pode ser, ao mesmo tempo, uma saudação de chegada e de partida. Diz-se "salut!", em francês, como quem diz um olá e também como quem diz um adeus. "Salvar a honra da razão" precisa ser lido nesses dois lances de partida ${ }^{386}$, ao se enunciar tal hipótese e ao seguir o labor de sua chamada.

Ainda, quando Derrida diz “o primeiro 'se...': 'E se fôssemos aqui chamados para salvar a honra da razão"”, encena o trabalho de sua tarefa-hipótese dentro da ficção de um tal imperativo ["é preciso salvar..."] que ecoa desde a herança da ética kantiana do agir "como se". A hipótese abissal e abismal do "salvar a honra da razão", em Derrida, suscitaria um "como se" sem horizonte ou, ainda, diria, só "se for" [desde a ida e a chegada da hipótese] sem horizonte. Ir

\footnotetext{
${ }^{386}$ De partida, em português, tem uma divisibilidade parecida com salut, não no sentido de ser uma saudação - de partida não é uma saudação. Mas a expressão guarda uma ambiguidade que pode remeter ao partir como começo e ao partir para o fim. Movimento de ida e de chegada que incide na partição do tempo e do espaço. De partida será uma expressão que usarei como recurso performativo para falar do momento de quase fim que também é abertura de um começo. De partida como espaço-tempo por vir.
} 
sem horizonte, nau à deriva, sem nenhum télos. Se é preciso salvar a honra da razão, o pensamento abissal incondicionalmente diria: só "se for" [no duplo de partida] em nome de nenhum fundamento, de nenhuma uma-mesma-língua, nem mesmo a capaz de reunir uma comunidade filosófica em torno dessa questão. Derrida nos lança para o abismo: "é preciso salvar a honra..." só se for salvando sem se salvar, sem redenção.

Navegando no deslize das palavras abissais de sua hipótese, mais adiante, Derrida nos escreve que o "salvar a honra":

(...) conota talvez o revés iminente, o anúncio de uma perdição - aí onde a razão corre o risco de perder ou de se perder, que se perca a razão, por exemplo na loucura, na extravagância ou na doença mental, que se perca a consciência ou a ciência, a lucidez responsável, ou ainda que a razão seja uma causa perdida ou é perdedora, diríamos nós, salvemos então a honra. Quando tudo parece declinar ou desmoronar-se, soçobrar ou assombrar-se, no último crepúsculo de um término [échéance] ou de um fracasso [échec], seria como se a razão, esta razão que tão rapidamente dizemos "nossa" ou "humana", não pudesse escolher senão entre dois fins, entre duas escatologias, entre duas formas de encalhar [échouer]: entre o encalhamento [échounement] e a encalhação [échouage $]^{387}$.

Encalhamos agora, e outra vez, no evento da paragem. Com a salvação abissal de Derrida, demos um giro e encalhamos outra vez nele. De certa maneira, eu estava conduzindo, capitaneando a nossa leitura até este evento para pensarmos a racionalidade da razão de seguir navegando até aqui ou se saltar para o quando depois por vir. Saltar de uma vez como desistência, sair do barco, ou continuar saltando nele, na atopia e na folia desse gesto. Depois de tanto calcularmos um horizonte e ainda assim nos depararmos com um acontecimento que se anuncia sem deixar ver sua chegada, por que razão seguir saltando nesse barco? Se a sua razão já nos chegaria perdida de razão, saltemos de uma vez por todas para o quando depois? E que momento um quando depois suscitaria? Perguntas igualmente abissais. [Estarei eu calculando o cálculo demais para fazer algum sentido seguir proferindo essas perguntas?] Por ora, só nos resta encalhar na sua paragem — se por um gesto acidental ou por um controle -, o acontecimento singular [por baixo e de chegada] que nos levou a elas.

\footnotetext{
${ }^{387}$ DERRIDA, 2009c, pp. 220-221.
} 
Vejamos o que Derrida nos diz desse evento que nos faz parar em duplo gesto de encalhamento/encalhação. Iremos parando aos poucos, demorando-nos sobre a cena naufrágica e apocalíptica "sem um deus para nos salvar" que Derrida desenha. Tentarei, no entanto, ainda, [como minha inabilidade confessa desde o início desta escrita] conduzir uma leitura com Derrida e para além de Derrida assumindo um estilo de força no seu pensamento que nos levará a outro salto. Aguardemos. Vamos de parada em parada. Salto a salto. Agora, avancemos na leitura de Derrida sobre os eventos do encalhamento e encalhação.

Primeira parada:

O encalhamento [échouement] é o momento em que o navio, ao tocar o fundo, se imobiliza acidentalmente. Este acidente é um evento: acontece, isto acontece porque, sem prever e sem calcular, se terá sido enviado pelo fundo. (...) Quanto à encalhação [échouage], não é o encalhamento [échouement]. A encalhação é o momento em que, desta vez intencionalmente, livremente, deliberadamente, de modo calculável e calculado, autônomo, o capitão de um navio, porque falha em manter a rota, assume então a responsabilidade de tocar o fundo - e esta decisão assemelha-se também a um evento. Mas o acidente do encalhamento, tal como dizíamos, também é um evento. Entre a encalhação e o encalhamento, suportaríamos o esforço desesperado para salvar de um naufrágio desastroso, no pior momento de uma derrota confessada, o que resta de honra no fim de uma batalha perdida por uma justa causa, uma causa nobre, a causa da razão que se faria questão em saudar uma última vez com a melancolia escatológica de uma filosofia enlutada ${ }^{388}$.

I - Seja no encalhamento, por acidente, por falta de controle, seja na encalhação, por decisão ou pela máxima do modo calculante, tripulado por um capitão autônomo, as duas paragens, nos diz Derrida, são eventos. E, se são eventos [acontecimentos ${ }^{389}$ ], poderíamos entender, ainda com Derrida, nessa mesma cena aqui desenhada, que ambas as paragens advêm sem antecipação, sem

\footnotetext{
${ }^{388}$ DERRIDA, 2009c, pp. 221-222. [Grifos meus].

${ }^{389}$ As diversas traduções do événement presente em diversas obras de Derrida, em português, repetidamente se revezam entre evento e acontecimento. Em inglês, em geral, é traduzido somente como event. A tradução ambígua do português, por sua vez, possibilita um recurso discursivo potencial de se pensar "o evento de um acontecimento". A tradução de Vadios (2009), de Fernanda Bernardo, opta por utilizar evento. A tradução de Pensar em Não Ver (2012), de Marcelo Jacques de Morais, opta por acontecimento. Morais ainda traduz a noção de arriver de Derrida como acontecer, lembrando em nota que pode ser traduzido também como chegar, jogo de sentido que, como vimos, Derrida adota nas últimas passagens que citamos de $O$ "Mundo" das Luzes Por Vir. [Para consultar a passagem e a nota em Pensar em Não Ver, $c f$. DERRIDA, 2012, notadamente, pp. 70-71].
} 
horizonte. Recordemos que, em outro lugar, em Pensar em Não Ver (2012), Derrida observa: “o acontecimento ['digno de nome', diria Derrida - e, oportunamente, tal dignidade nos lança, outra vez, para a questão do 'salvar a honra'] não tem horizonte; só há acontecimento ali onde não há horizonte”390. Mesmo no caso do gesto tripulado de paragem — se tal evento é um acontecimento - , há ainda no momento de sua chegada uma imprevisibilidade de repouso. O capitão que decide encalhar o barco vê à frente a margem do horizonte, mas não pode ver, a bordo de seu navio, o momento em que a proa do barco toca e se arrasta no solo. Ele não pode antecipar essa chegada. Eis, assim, sua espera aflitiva: nem com os olhos que avistam a margem nem com as mãos que manipulam o timão e o bordo do navio, ele não prevê a paragem. Ele para sem ver e sem tocar. Nessa imprevisibilidade incondicional da paragem de qualquer navio que encalha, seja por encalhação ou encalhamento, não há nada que possamos "salvar" no sentido que essa palavra reserva de "resgate". Nada podemos salvar, pois não temos olhos nem mãos para antecipar a vinda que vem de baixo. No entanto, nos restam os pés - esses que nada podem prevenir-vendo, mas, sim, podem sentir ainda o tremor da encalhagem, seja ela qual for, sempre acontecimental. Os pés podem ainda nos ajudar a correr, nadar, mesmo sem mãos, sem braços e sem olho; um nado esquartejado, desesperador, imagino. [E aqui peço desculpa ao leitor por eu ter que usar uma pressuposição normativa de que os corpos que habitam esse navio têm um corpo com todos os membros e olhos como se partisse de uma noção de "boa forma" ou de "um corpo bem formado". Queria poder escrever uma alegoria mais radical, partindo de um corpo-capitão mais dissimétrico, com alguma falta de membro ou com imobilidade ou, então, que sofresse de gota ou outra enfermidade nos membros. Infelizmente, não pude ficcionalizar uma alegoria mais radical, tendo em vista a rota que preciso seguir o mais economicamente possível às margens do fim. Peço perdão, antecipadamente, ao leitor que me acompanhou antes fazendo uma crítica a Arbeau e seu pressuposto de ensinamento coreográfico normativo ${ }^{391}$. Tive que telecoreografar esse gesto que reserva algum recalque, incondicionalmente, por economia de tempo. Pelo recalque, ao mesmo tempo, peço perdão].

\footnotetext{
${ }^{390}$ DERRIDA, 2012, p. 71. [Comentários meus].

${ }^{391}$ Vide a segunda seção.
} 
II - A metáfora usada por Derrida para pensar sua hipótese abissal ("se salvar a honra da razão") na espera da paragem, no "entre" encalhação e encalhamento, no momento ainda indeciso quando não se sabe o que fazer, se deixar afundar por si ou levar ao fundo por uma decisão de rumo igualmente cega, imprevisível, mantém ainda "o esforço desesperado para salvar [a causa da razão] de um naufrágio desastroso". Daí ecoa um "é preciso uma salvação", porém, como uma saudação de saída. "Salut", um adeus: "saudar uma última vez com a melancolia escatológica de uma filosofia enlutada". O luto e a melancolia marcam um gesto singular nessa cena de se pensar um porvir para a filosofia quando depois do naufrágio da filosofia. Porém, atento à impressão freudiana que marca o pensamento de Derrida e também atento à distância que Derrida imprime em seu pensamento em relação a Freud. É preciso dizer que luto e melancolia devem ser lidos aqui como trabalho em marcha, sempre por vir ${ }^{392}$. Nessa cena melancólica de uma filosofia enlutada, Derrida imprime a sua ética mais radical na qual acolhe a impossibilidade de se ter o porvir, o destino, o horizonte sob as mãos e os olhos ${ }^{393}$. Tal afirmativa pode ser entendida e suplementada com uma nota de Fernanda Bernardo que nos fala sobre a ambiguidade da tradução do "il faut" derridiano.

O "il faut" simultaneamente presente do indicativo do verbo falloir (precisar) e do verbo faillir (faltar) e significando, por isso, ao mesmo tempo "o que é preciso" e "o que falta" — tanto revela a incondicionalidade metaética da desconstrução derridiana enquanto pensamos com sua aporética irredutível ${ }^{394}$.

\footnotetext{
${ }^{392}$ De forma telegráfica, poderia marcar essa diferença lembrando que em Freud, o luto seria um período transitório pelo qual o sujeito reelabora sua experiência para superação da perda do outro. Quando não há essa superação, o sujeito cai em estado de melancolia. Para Freud, o luto não é um estado patológico, mas a melancolia é a abertura a uma predisposição patológica que precisa ser tratada. Em Derrida, o luto é um estado permanente de trabalho da relação com o outro tendo em vista sua alteridade radical. Se há alteridade radical do outro, só há perda do outro. Nunca se teve o outro para si, por sua vez, nunca havendo perda do outro para si. Há uma permanência de estado melancólico, de sofrimento incondicional que, no entanto, para Derrida não é uma patologia. Para Derrida, luto e melancolia são, assim, noções suplementares de trabalho sempre por vir na relação com o outro. Para ler sobre luto e melancolia em Freud, $c f$. FREUD, Sigmund. Luto e Melancolia. In: Obras Completas de Sigmund Freud vol. XIV. Rio de Janeiro: Imago, 1920. Para ler sobre a démarche do trabalho de luto e melancolia em Derrida, $c f$. DERRIDA, Jacques. Eating Well or the Calculation of the Subject. In: CONNOR, NANCY, CADAVA (Editors). Who Comes After the Subject? New York: Routledge, 1991.

${ }^{393}$ Retomarei, logo mais, essa impossibilidade de se ter o porvir sob as mãos e os olhos para pensar o desafio de uma teorização por vir e sua relação com as noções de previsão, de apreensão, de posse e de domínio. Por ora, peço ao leito que grife essa passagem.

${ }^{394}$ Ver N.T. em: DERRIDA, 2009c, p. 216.
} 
Quando eu disse acima "É preciso uma salvação, porém, como uma saudação de saída", quis pensar a radicalidade dessa metaética [como veremos mais adiante, para Derrida é também uma "hiperética" e uma "hiperpolítica"]; a radicalidade entre a necessidade e falta do luto e da melancolia que não podem ser mais associados com a noção de lamentação. Na metaética da desconstrução que pensamos aqui, sofre-se de luto e melancolia sem lamentar. Essa cena desesperadora está entregue, atopicamente, sem horizonte, à noção de ética como trabalho radicalmente por vir, portanto um trabalho radicalmente em marcha. Trabalho de partida: "filosofia enlutada", nos diria Derrida. Nos deslocamentos das traduções e das travessias que nos trouxeram essa aporética, poderia também dizer, talvez: "se for para salvar a honra..." que seja um trabalho enlutado. Continuemos.

Segunda parada:

\begin{abstract}
Aí onde não se pode salvar mais nada, tenta-se então salvar a honra da derrota. Salvar a honra não seria salvação [salut] que salva, mas a salvação [salut] que apenas saúda uma partida aquando da separação do outro. Filosofia enlutada, dizia eu, ou porque o mundo estaria prestes a perder a razão, até mesmo a perder-se como mundo, ou então porque a própria razão, a razão como tal, estaria prestes a tornar-se ameaçante; ela seria um poder, teria o poder de se ameaçar a si própria, de perder o sentido e a humanidade do mundo. De perder a si própria, de naufragar por si própria, eu preferia dizer de se autoimunizar para designar esta estranha lógica ilógica pela qual um vivente pode espontaneamente destruir, de forma autônoma, aquilo mesmo que, nele, se destina a protegê-lo contra o outro, a imunizá-lo contra a intrusão agressiva do outro $^{395}$.
\end{abstract}

1 - "Salvar a honra da derrota", nos diz Derrida. Não salvar a derrota de si, mas, sim, deixá-la sofrer de sua autoimunidade. Salvação, como saudação e como partida "aquando da separação do outro". Aqui a questão do luto novamente se coloca como uma ética de trabalho sem horizonte. Acolher a perda radicalmente; acolher a perda de mundo e também a perda da razão é o apelo de um “é preciso uma filosofia enlutada”. Aí, nesse momento de luto/melancolia, quando não se tem mais horizonte, só nos "resta salvar a derrota", tê-la desde $a$

${ }^{395}$ Idem, pp. 222-223. [Grifos meus]. 
partida como trabalho. Esse trabalho, por sua vez, nos alerta Derrida, "estaria prestes a tornar-se ameaçante", pois seria "autoimunizante".

2 - Uma filosofia enlutada prestes a perder a razão por sua autoimunidade, sua ilógica lógica de destruir em si "aquilo que o protege do outro" - e poderíamos dizer também que recalca o outro e o faz manter a distância. Autoimunidade é o que nos falta. Anticorpo contra os corpos e a normatividade dos corpos que barram a chegada do outro. Sobre essa outra filosofia sugerida por Derrida, a filosofia enlutada prestes a perder a razão, poderíamos afirmar que se trata de uma filosofia do sim, sim: aberta e sensível ao outro, mesmo o mais intruso e dissidente outro, agressivo e indócil outro, aberta ao totalmente outro, na sua atopie-folie. Filosofia que está prestes a perder a razão, prestes a perder o mundo, sair de si. Filosofia sem desejo de ter a razão, sobretudo a razão do mais forte. Uma filosofia, portanto, que se confunde com a força fraca. Acolhe radicalmente a todo outro que vem já de partida e já saudandoo de partida: salut! — e o eco de partida como um adeus é aqui fundamental, pois a filosofia é enlutada, não esqueçamos. Ela, portanto, não guarda pra si nada como seu, nenhum objeto nem nenhum sujeito, e por isso mesmo sofre de melancolia, sofre da perda, sem lamentar. Nenhum cálculo consegue assegurar ou capitalizar plenamente a vinda e a chegada desse outro que já vem partindo e de partida e também partido de partida. Nenhuma razão; nenhuma razão para seguir nessa filosofia enlutada já estando nela. Só se for em nome da dignidade de uma razão por vir. O evento "entre" encalhamento e encalhação desenhado por Derrida chega, então, a uma aporia incalculável.

Uma outra passagem, mais adiante, de O "Mundo" das Luzes Por Vir, pode radicalizar ainda mais essa incalculabilidade. Saltemos para essa outra paragem:

Se um evento digno deste nome deve chegar ou acontecer, é-lhe preciso, para além de todo e qualquer domínio, afetar uma passividade. Ele deve tocar uma vulnerabilidade exposta, sem imunidade absoluta, sem indemnidade, na sua finitude e de modo não horizontal, aí onde não é ainda ou não é mais possível fazer face, e fazer frente, à imprevisibilidade do outro. A este respeito, a autoimunidade não é um mal absoluto. Ela permite a exposição ao outro, ao que vem e a quem vem - e deve portanto permanecer incalculável. Sem autoimunidade, com a imunidade absoluta, nada mais aconteceria. Não se 
esperaria mais, não nos esperaríamos mais, não nos esperaríamos mais um ao outro, nem a nenhum evento ${ }^{396}$.

Eis a espera desesperadora do naufrágio que precisamos salvar. Salvar a honra da derrota, que grifei na outra paragem, nunca foi tão im-preciso [incerto, necessário, faltante]: à espera da encalhagem [seja ela como for] que vem por baixo; à espera desse acontecimento que vem por baixo - "que não se dá face a face”, ao qual não podemos fazer frente; a essa espera estamos lançados ao porvir. É desesperador mas também libertário, pois saúda a chegada do outro. A autoimunidade, esse anti-anticorpo ilógico e cruel, destruidor da ipseidade indivisível, abre, outra vez, a filosofia enlutada [essa que não é propriedade da filosofia institucional e que é uma chamada à abertura da filosofia no seu sim, sim], diz sim à chegada do outro por vir.

Sobre essa filosofia enlutada encenada como um evento prestes a perder a razão e o mundo, prestes a "perder a si própria, de naufragar por si própria", Derrida escreveu antes: "preferia dizer [prestes] de se autoimunizar". E logo depois:

O que é preciso pensar aqui é esta coisa inconcebível ou incognoscível, uma liberdade que não seria mais o poder de um sujeito, uma liberdade sem autonomia, uma heteronomia sem servidão, em suma, algo assim como uma decisão passiva. Para tal, haveria que repensar filosofemas da decisão e do par fundador da atividade e da passividade, bem como da potência e do ato. É então racional, legitimamente racional, interrogar ou desconstruir, sem com isso desacreditar a fecunda distinção entre constativo e performativo. Tal como, para além do direito, da dívida e do dever, seria preciso pensar racionalmente [e esse gesto requer tanto uma noção de reserva, de cautela para não cair no hybris do excesso de cálculo, como também uma incalculabilidade do cálculo, de uma razão por vir, poderíamos dizer] uma hiperética ou uma hiperpolítica que não se contente em agir "em conformidade com o direito (pflichtmässig)" nem mesmo (para retomar a distinção kantiana que funda a razão prática) "por puro dever" (eigentlich aus Pflicht, aus reiner Pflicht). Esta hiperética ou esta hiperpolítica ergue-se incondicionalmente para além do círculo econômico do dever ou da tarefa (Pflicht ou Aufgabe), da dívida a reapropriar ou a anular, do que se sabe [grifo de Derrida] deve fazer e que, portanto, depende ainda de um saber pragmático e normativo que ela se contenta em desenrolar consequentemente ${ }^{397}$.

\footnotetext{
${ }^{396}$ DERRIDA, 2009c, p. 267.

${ }^{397}$ Idem, p. 268. [Grifos e comentários meus].
} 
É preciso pensar a filosofia enlutada de Derrida. Um apelo a uma hiperética e uma hiperpolítica por vir. Apelo também de uma democracia por vir como a de uma liberdade de decisão passiva sem servidão. Encalhamos aí, no seu gesto duplo, uma paragem por vir a um só golpe: evento por vir, democracia por vir, razão por vir! Um golpe incalculável para além da dívida, do direito e do dever que precisamos pensar, sem que esse "É preciso..." agende uma pragmática. Um pensamento impossível daqueles, com a desconstrução necessária, quando já dizemos "só o impossível acontece". Derrida nos convoca, justamente, a um pensamento sem previsibilidade, sem antecipação, portanto sem agenda e fora da agenda das possibilidades. A incalculabilidade de seu cálculo, de sua hiperética e de sua hiperpolítica é aqui outside the square ${ }^{398}$.

Filosofia enlutada, de partida. Salut!

\section{1. \\ Saltando Para Uma Teorização Por Vir na Dança}

Iniciei esta seção reescrevendo a promessa do "quando o pensamento vem dançando". Em múltiplos saltos, de paragens a paragens, encalhamos com Derrida na chegada de uma hiper-ética e de uma hiper-política enlutadas que me colocam prestes a perder a razão de ainda seguir a bordo da tarefa de fazer teorias. É preciso falar do problema da teoria, sobretudo da tarefa de uma teorização específica em que já estou afundado e cuja proa sinto arrastar desde os pés. Falo da tarefa de teorização da dança: enquanto sinto o tremor às margens do seu naufrágio. Para responder a esse naufrágio, precisarei saltar a um salut singular: é preciso enlutar a teoria da dança.

Desde um gesto duplo de navegação e de escavação da palavra teoria, notaremos que pensar esse enlutamento demanda muitas paragens. Por um lado, theoria remete a uma noção de procissão ou cortejo ritual em honra a um deus (theos, o divino), o instigador, que não somente arrebata aqueles que zelam pelo

\footnotetext{
${ }^{398}$ Falei anteriormente, no final quinta seção, sobre a potência dessa expressão na língua e no pensamento de Butler. Se pudesse, diria ao leitor em segredo: retornar e ler novamente aquele trecho, pensando já na incalculabilidade desse gesto.
} 
seu desígnio, portanto cuidam e se demoram no seu evento (são reconhecidos como autores do evento), como também reúne uma série de anônimos, desocupados atraídos pelo evento que causam um rumor teórico ${ }^{399}$. Por outro lado, theorein, remete a olhar, dar-a-ver pela contemplação. Reserva-se aí um privilégio óptico que é também o privilégio das Luzes, que desliza entre o heliocentrismo e o haptocentrismo do tato, do tocar sem tocar, manter a distância e deixar a coisa intacta ${ }^{400}$. Theorein faz dobras no encadeamento semântico que chega à noção de teatro, repartida entre theomai (ver com atenção) e théatron (o que dá-a-ver). Há também outra dobra que nos leva à noção de theorós ${ }^{401}$ — enviado por um rei para consultar um oráculo, para assistir uma festa religiosa, um espetáculo ou os jogos olímpicos, como um espectador comissionado ${ }^{402}$. Em theorós, encontra-se, sobretudo, o sentido de viagem e de testemunho, como também reserva uma singularidade sobre a tarefa política do envio, da embaixada, da economia da representação e da divisibilidade do soberano que espera a distância. O olho do rei, e de qualquer soberano, do poder de consignação de uma soberania e também de seu poder de theorein calcula, a distância, através de sua substituição por um theorós.

Os arquivos que se abrem nessa escavação/navegação oportunizam diferentes faros a seguir. No entanto, não podemos deixar de notar que o privilégio das Luzes e da sua prerrogativa de antecipação da margem, do outro por vir para o/pelo cálculo restringiu, reiteradamente, a noção de teoria a uma tecnologia óptica (do ver a distância). Não somente por uma questão de desejo das luzes, a experiência da normatização do corpo bem formado que faz teoria e que tem os olhos abertos à frente do corpo é uma evidência.

Mas eu havia prometido saltar para o pensamento da tarefa de teoria por vir na dança. Saltar num gesto econômico, já partindo para o fim da navegação desta tese. Para tanto, precisarei retornar a uma passagem de Pensar em Não Ver

\footnotetext{
${ }^{399} C f$. CAUQUELIN, 2005.

${ }^{400} C f$. DERRIDA, 2012.

${ }^{401} C f$. LIDDEL \& SCOTT, 1940.

${ }^{402}$ Preciso registrar um agradecimento especial ao colega de doutorado André Stock, que, após a leitura do texto preliminar da minha tese, me apontou um retorno à noção de theorós.
} 
$(2012)^{403}$, conferência em que Derrida nos oferece alguns suplementos para nossa discussão.

Escolho esse texto como um desvio para nosso salto porque é exatamente nessa conferência que Derrida irá discutir os desafios de pensar para além do ver a questão do acontecimento. O filósofo franco-argelino toma como estratégia a discussão de questões que surgem entre a noção de desenho e visão - se o desenho é uma arte do visível, se o desenho dá-se na experiência do visual. Não seguirei todas as questões desenvolvidas por Derrida para nos lançarmos a um salto ao pensamento de uma teorização em dança por vir - essa é a promessa.

O elo entre minha questão - a de pensar uma teorização por vir na dança - e o Pensar em Não Ver, de Derrida, se dá a partir de uma passagem em que ele pensa a evidência de predisposição do olho sempre à frente, da predisposição dos olhos que fazem face e uma certa predisposição à luz através do olho que, como nos alerta o filósofo, não é comum a todos os seres vivos:

(...) nem todos os seres vivos têm o que chamamos de olho; há seres vivos, e é o caso da maior parte deles, que são sensíveis à luz, que precisam da luz ou do sol e que reagem biologicamente, geneticamente, à luz, que precisam dos efeitos da luz sem, contudo, ver, sem ter olhos que façam face a alguma coisa, ao que está precisamente em face deles, ao que chamamos normalmente de objetos. Há animais que não têm objeto nesse sentido, mas nós, os homens, os mamíferos e um certo número de outros animais, temos olhos. Não apenas somos sensíveis à luz como também vemos, e devo dizer que uma das funções - não direi uma das finalidades para não parecer demasiado telegráfico desde o início - mas em todo caso uma das funções vitais do olho, do olhar equipado de olhos, é precisamente a de ver vir, isto é, de nos proteger, de nos proteger contra o que vem. Para nos proteger, antecipamos, antecipadamente. "Antecipar" quer dizer tomar previamente (antecapere), apoderar-se previamente. A antecipação já é algo que, na maioria das vezes, com a ajuda das mãos, vai ao encontro do obstáculo para prevenir o perigo. Junto ao léxico da antecipação, temos o da a-preensão, o léxico manual, se podemos dizer $\operatorname{assim}^{404}$.

Nessa passagem, Derrida nos fala sobre a predisposição de certos "homens, animais mamíferos" que têm os olhos sensíveis à luz, olhos videntes

\footnotetext{
${ }^{403}$ Conferência pronunciada por Jacques Derrida em Orta, na Itália, em 2002, posteriormente editada em Annali, Fondazione Europea del Disegno, em 2005, e publicada em português no livro Pensar em Não Ver: Escritos Sobre a Arte do Visível (2012) [cf. DERRIDA, 2012b].

${ }^{404}$ DERRIDA, 2012, p. 69.
} 
que antecipam, com auxílio das mãos, a chegada do que se deixa ver vindo. Notemos duas brechas importantes deixadas por Derrida: essa coisa que se deixa ver vindo é o que normalmente chamamos de objeto; e aquele que antecipa a vinda do que vem, para se proteger, faz o uso da habilidade de antecipação entre olhos e mãos ${ }^{405}$.

Sobre a primeira delas, é preciso lembrar a discussão que desenvolvi na seção anterior sobre a impossibilidade de se pensar a dança como um objeto quando dizemos sim à sua espectralidade. Se as telecoreografias desenhadas até o momento foram capazes de imprimir alguma singular abertura que se dá ao dizer sim ao siga-me, guarde-me, adeus, acredito que não temos mais como pensar a noção de objeto de dança. A dança, diferentemente de uma mesa, não permanece no intervalo de um piscar de olhos (blink); quando abrimos e fechamos os olhos diante de uma dança, nada permanece diante de nós como a permanência de um objeto.

A segunda brecha é complementar à primeira, na medida em que também assumimos que a vinda de uma dança [repito: se dizemos sim ao siga-me, guardeme, adeus] causa tremor à habilidade do cálculo que se dá entre olho e mão. A dança de uma mesa, se mesas dançam, causa uma certa instabilidade de apoio sobre. Apoiar-se sobre uma dança para teorizar sobre ela não é uma tarefa nada dada às mãos e aos olhos. A dança não se dá no horizonte do equipamento óptico e, no seu movimento constante de mudança de lugares, não nos oferece, tampouco, uma base estável de apoio. É nessa inabilidade que se encontra o desafio de uma teorização por vir na dança. Ou ainda, em outras palavras, podemos dizer que é somente no sim a uma certa inabilidade que podemos pensar na tarefa enlutada de seguir pensando danças já abertos ao seu sofrimento e melancolia de partida, já abertos à radicalidade de seu porvir.

Mas em que o pensamento de tal inabilidade entre olhos e mãos auxilia na nossa discussão sobre a tarefa de uma teorização por vir? Duas passagem de Derrida (2012) podem nos auxiliar, como um trampolim, para o fole dessa discussão. A primeira se inscreve na aproximação entre a noção de teoria e o domínio de conceitos pelas mãos:

\footnotetext{
${ }^{405}$ Notemos aqui uma feliz aproximação com a discussão que tivemos na seção anterior da tese, quando falamos que o filósofo vê e teoriza sobre os objetos que tem à mão. A circulação da mesa de Marx, da mesa de Derrida, da mesa de Husserl. A mesa como objeto de apoio do trabalho filosófico.
} 
(...) no léxico da antecipação temos todo o espectro semântico da percepção ou do conceito, a percepção é também a pegada manual, uma maneira de apreender, o Begriff, o conceito. Begreifen é aprender, tomar para dominar, e, portanto, o conceito tem isso em comum com a percepção. (...) O conceito tem em comum com o percepto ao menos o fato de engajar a mão que pega, a apreensão. O cego avança com apreensão, isto é, com uma espécie de inquietude que consiste em tomar previamente a coisa de que ele precisa ou de que ele precisa proteger-se. Logo, a visão é também apreensão. Não digo que a visão seja apenas isso. Mas a visão, os olhos videntes e não os olhos que choram, está lá para prevenir, por antecipação, por pré-conceptualização, por percepção: para ver vir o que vem ${ }^{406}$.

\section{A segunda passagem trata da conformação da noção de teórico pela} teoria da contemplação, o theorein, e sua habilidade apreensiva entre olhos e mãos de tocar sem tocar:

Em todos os textos, de Platão a Husserl, os valores, digamos, oculares ou ópticos, os valores transidos de luz, estavam a serviço do que chamo de um haptocentrismo, isto é, uma figuralidade que privilegia o tocar, o contato - ou o tato (espécie de tocar sem tocar). A cada vez, o ápice da experiência da verdade se dizia na figura do contato e não na figura da visão. (...) O teórico, a instância do olhar, diferentemente do tocar, deixa a coisa ser o que ela é: deixa-a intacta. O teórico foi privilegiado em particular como o medium da verdade ${ }^{407}$, pois a diferença entre olhar e tocar é que se olha a distância e que, consequentemente, se deixa a coisa ser o que ela é: não a comemos $^{408}$.

Essas duas passagens nos transportam novamente para a questão do corpo no pensamento na noção de theorein como o haptocentrismo: tocar sem tocar, entre olhos e mãos. Tal theorein demanda, porém, um corpo normatizado, um corpo bem formado com olhos e mãos habilidosos. Corpos táteis, sensíveis à luz e à vinda da luz que, sobretudo, podem se proteger da luz e apreender a luz sendo um medium da verdade; sendo um meio de condução à verdade. Esses corpos singulares da theorein tocam, por sua vez, sem tomar para si. A coisa

\footnotetext{
${ }^{406}$ DERRIDA, 2012, pp. 69-70.

${ }^{407}$ Nesse sentido de medium, há, a meu ver, um rastro da noção de theorós de que falei antes: o gesto teórico de um embaixador da verdade que nos conduz a uma viagem para tocar sem tocar a verdade. Há uma questão política, econômica e representativa da verdade, da substituição da verdade em si, que nos vêm pelo pensamento medium da verdade que Derrida não desenvolve.

${ }^{408}$ DERRIDA, 2012, p. 84. [Comentários meus].
} 
tocada deve permanecer lá, na justa distância necessária ao cálculo, para que não se confundam o olho e as mãos com a própria coisa. Vemos, como tais teóricos, as coisas e não as comemos. Derrida ainda lembra que:

Hegel ressalta isso, a preeminência do teórico é que não se come a coisa; o animal a come, ele quer assimilá-la, ele destrói e toma-a em si, ele a assimila, ao passo que o teórico, o homem da verdade, o filósofo olha e, consequentemente, respeita: respeitar é relacionar-se com algo ou com alguém a distância, sem tocá-10 ${ }^{409}$.

Nessa escavação das impressões sobre a teoria e o teórico, com Derrida, chegamos ao limite em que a dança começa a tremer. Ou melhor, aqueles que dançam, que seguem danças e telecoreografias [bailarinos de direito ou bailarinos sem ser], já guardando danças em si [ainda que na constrição de instante do sigame, guarde-me, adeus], encontrariam uma barreira na tarefa da teorização. Se fazer teoria é uma experiência tátil sem comer o outro, como faz um animal hegeliano, não há como pensar em teorias da dança. As experiências com a dança reservam algum traço de animalidade: só se dança incorporando, comendo o outro, assimilando o sofrimento da sua partida, da sua destruição como propriedade em si. Não há objetal, não há como haver qualquer respeito ao objetal quando já numa telecoreografia. Tudo é expropriado, roubado de propriedade. A dança conjura a apreensão já expropriada [lembremos: siga-me, guarde-me, adeus! — num só gesto]. Dança-se sempre na experiência com a perda, na atopia e no delírio da perda de uma ipseidade indivisível.

Porém é preciso lembrar que, se essa noção de teoria é uma noção de impressões sobre a teoria, construída a partir de muitos gestos, heranças e iterações arquivadas sobre teoria, ela é, portanto, desconstrutível. A desconstrução da noção de teoria começa já marcada no seu princípio arcôntico: teoria guarda na sua arqui-história, ao menos, três princípios divisíveis - theoria, theorein e theorós. Ainda evoca uma forma de reunião em torno de um télos, de um divino; a forma de apreensão pela contemplação; e também uma experiência de corpo divisível, substituição em viagem, experiência e incorporação pela viagem, saída de si da soberania por representação, embaixada, partição do uno, medium (experiência transcendente) da verdade. E não podemos esquecer a sua

\footnotetext{
${ }^{409}$ Ibid.
} 
aproximação com theomai e thetrón, noções que imprimem em teoria outro gesto oportuno: como teatro, que nem sempre se dá no espaço teatral, na casa teatral, para circular em cena como cena, ela (a teoria) é sensível à alteridade do tornar-se público. A noção de teoria como mera contemplação sofre, assim, múltiplos abalos desde a virtualidade de suas impressões arquivadas entre teoria, theorein e theorós, como também em theomai e theatrón.

Poderíamos ainda desconstruir a noção de teoria restrita a uma "certa" habilidade entre mãos e olhos forçando um retorno à cena de esquartejamento que telecoreografei - incorporei/excorpoando - com a filosofia enlutada de Derrida. É preciso deslocar a normalização do corpo da teoria, de uma certa noção normatizadora do corpo que faz teoria aquando já não tem olhos nem mãos para nos salvar à beira de uma experiência abissal de paragem que vem de baixo. $\mathrm{Ou}$, ainda, quando, mesmo tendo olhos e mãos, já não podemos ver vir a vinda que vem, seja ela por baixo, por cima ou pelos lados, ali quando nem olhos nem mãos são capazes nem de aprender nem de se proteger. Quando a vinda de um evento é tão radicalmente inesperada como um acontecimento digno de nome que leva os olhos a se inundarem com as lágrimas; quando, no instante de um blink, os olhos deixam de ser somente videntes e passam a ser também os olhos que choram e já não podem ver o horizonte plenamente. Olhos sensíveis a outra vinda que não a luz ou sensíveis a outras luzes que não são a da razão.

Quando choramos diante desse outro radical, ainda estamos pensando? Ou perdemos a razão do pensamento de vez?

Uma teorização da dança por vir pode tomar força quando depois da chegada dessas outras luzes, dessas outras águas. Quando depois do sim, sim, necessário e sempre em falta, da teoria como um pensamento cego que "avança com apreensão, isto é, com uma espécie de inquietude que consiste em tomar previamente a coisa de que ele precisa ou de que ele precisa proteger-se" ${ }^{\$ 410}$ _ incorporando as palavras de Derrida que citei anteriormente, agora já deslocadas de seus lugares, agora já tele-encenadas, telecoreografadas como se pudessem dizer algo sobre a dança. Dessa teorização por vir, talvez, não aprenderemos

${ }^{410}$ DERRIDA, 2012, p. 69. 
nenhum corpo bem formado, nenhuma lição, nenhuma ontologia, nenhum objeto. Teoria que se confunde com o corpo a corpo como um theorós: errância de envio, inábil de construir qualquer conceito em si, para si, sem a exposição ao outro. Tudo no espaço-tempo de um theorós vem do outro e é enviado ao outro. De faro a faro na sua viagem, só há pensamento roubado.

[Tudo roubado! - diríamos na folia de um delírio. Performatividade escatológica parricida. Nem performativo nem constativo. Arrombamento diferencial. Sem objeto, deus, propriedade, eidos, nem um télos reguladordifícil se entregar a essa dança! Paragem. Outro fôlego. Tudo roubado. Sim, sim, roubo do roubo. (Esse parêntese também foi roubado. Está sendo roubado ${ }^{411}$ ). Siga-me, guarde-me, adeus. De partida, já e quando depois. Corpo a corpo, salto a salto. Desde a carne. Retorno remissivo. Comida de animal. Faro a faro. Efração furtiva, arrombamento advindo do roubo e da abertura de orifícios. Escatologia parasita assombradora. Naufrágio sem logia, sem messias. Difícil entrega, outra vez. Laboriosa telecoreografia. Trabalho por vir. Sem segurança, sem desígnio. Teorização impossivel? Ainda teoria? Nesse colchete, já e quando depois?]

Sem poder enceguecer na folia de tal pensamento, não posso dizer que não existem experiências de teorizações da dança que refletem e deslocam suas práticas. Sim, elas existem, as estudamos, dialogamos corpo a corpo com algumas

\footnotetext{
${ }^{411}$ Sim, sim... nada meu. Ecos de um'a palavra soprada, roubada de Artaud, roubada por Derrida: "O meu corpo foi roubado por efração. O Outro, o Ladrão, o grande Furtivo tem um nome próprio: é Deus. A sua história teve lugar. Teve um lugar. O lugar da efração só pôde ser a abertura de um orifício. Orifício do nascimento, orifício da defecação aos quais remetem, como à sua origem, todas as outras aberturas. [Observem o rapto:] 'Isso se enche,/ isso não se enche,/ há um vazio,/ uma carência,/ uma falta de/ quem é sempre apanhada por um parasita no voo' (abr. de 1947). No voo: é certo o jogo de palavras. Desde que me relaciono com o meu corpo, portanto desde o meu nascimento, não sou mais o meu corpo. Desde que tenho um corpo, não o sou, portanto não o tenho. Esta privação institui e instrui a minha relação com a vida. Portanto, desde sempre o meu corpo me foi roubado. Quem pode tê-lo roubado senão um Outro e como pôde apoderar-se dele desde a origem se não se tiver introduzido em algum lugar no ventre da minha mãe, se não tiver nascido em meu lugar, se eu não tiver sido roubado no meu nascimento, se o meu nascimento não me tiver sido sutilizado, [outra vez] 'como se nascer cheirasse morte desde há muito tempo' (84, p. 11)? A morte dá-se a pensar sob a categoria do roubo. (...) E quem pode ser o ladrão senão esse grande Outro invisível, perseguidor furtivo duplicando-me por toda parte, isto é, redobrando-me e ultrapassando-me, chegando sempre antes de mim aonde escolhi ir, como 'esse corpo que corria atrás de mim' (me perseguia) [quem? eu?] 'e não seguia' (me procedia), quem pode senão um Deus? [eu?] 'E O QUE FIZESTE DO MEU CORPO, DEUS?’'(DERRIDA, 2009a, p. 264, comentários meus, grifos do autor).
} 
delas ao longo desta tese. O pensamento de uma teorização por vir começa e tem como lei tal pressuposição. Porém o trabalho de uma teorização da dança por vir, no compromisso por-vir de sua tarefa enlutada, precisa se colocar na escavação desses suportes, vasculhando os seus arquivos, multiplicando as suas aberturas e seus orifícios, sem deixar que nenhuma unidade centralizadora se afirme como fim e começo de todas as teorias. É preciso se entregar l'atopia et la folie. É preciso fazer as teorias da dança tremer e sofrer na sua autoimunidade. E, assim, é preciso também dizer que a teorização de dança, como pensamento por vir, não está restrita a nenhum domínio ou campo de saber. Não está restrita às escolas e aos departamentos de dança nem a nenhum discurso de construção de epistemologias próprias. Também não se coloca como uma ontologia da dança, nem mesmo se essa for a de uma ontologia do movimento da dança; do movimento dos corpos que dançam. É preciso, sobretudo, pensar a predominância de um discurso da teoria da dança restrita ao estudo e à análise de movimentos de corpos dançantes.

Ao colocar este último “É preciso...", não pretendo abrir mão do vigor do movimento, da fisicalidade advinda pelo movimento de uma dança, pelo contrário, estou querendo pensar num movimento mais radical que não se dá como fluxo contínuo. A tarefa sempre por vir é de pensar o limite dos espaços consensuais e de direito da dança; pensar quando a dança treme, quando sua suposta soberania de estar sempre em movimento, "circulando livremente", falha. Acredito que precisamos ainda questionar se a tradução imediata, o transporte sem demora, entre "dança" e "movimento", cria aberturas, diz sim ao pensar, ou enclausura rotas de discussão para outras teorias da dança. Esse lugar supostamente seguro, de movimento direto, precisa tremer. [Fé sem garantias, faro sem horizonte. "É preciso..." como necessidade e falta.]

As telecoreografias encenadas nesta tese não puderam ser marcadas sem deixar de pensar como a palavra dança arquiva impressões históricas, fenomenológicas e ontológicas de movimento. A dança se move, poderíamos dizer, evidentemente; essa é uma evidência em que não precisamos nos demorar muito para intuir, apreender como uma memória de dança. No entanto, precisamos ainda refletir como essas impressões visíveis de movimento [do que é apreendido, percebido e conceituado como movimento ou não] se deslocaram ao longo dos tempos escrevendo e arquivando impressões singulares na palavra 
dança. Dança arquiva impressões históricas, por vezes repressivas e supressivas, que recalcam outras danças, interditando por direitos e ritmos bem marcados, bem singulares. Dizer dança, diferentemente de dizer movimento, reserva alguma arqui-história singular inscrita no seu corpo, na sua reunião de experiências e de movimentos distintos, alguns incorporados por uma certa tradição de dança e outros não.

As noções de dança e movimento guardam impressões uma na outra, mas, se nos demorarmos mais insistentemente na pulsão que as anarquiva, outros escapes, outras fugitividades poderão se imprimir. Essa tem sido a tentativa de problematização na minha escrita: essa chamada dança, chamada desde sempre pelo outro, interpelada como um "ei, tu, bailarino" ou "ei, tu, baderneiro". Tal dança é incondicionalmente desviante, mas não como um continnum em fluxo, e sim como uma iterável singularidade viscosa e tropeçante.

Podemos chamar pensamentos de dança para além de uma vinculação de quando se quer-dizer-estar-dançando - como quando no espaço seguro de um teatro, ali, diante dos olhos, se profere uma dança que se anuncia e é esperada enquanto tal. A dança pode acontecer sem se deixar ver vir no seu rastro enquanto dança. A iterabilidade do chamado à dança - atribuo ao mesmo nome dança um espetáculo, ou uma ação cotidiana, ou uma badernagem na rua, ou uma paragem em frente a uma porta, ou um momento sentado numa mesa - não garante nenhum campo de sentido próprio ao que se chama de dança. Eis o porvir do chamado à dança como força fraca: ela mesma nada comunica, nada pode comunicar por si. Demanda uma escritura com múltiplas telecoreografias que não são em nada parecidas com a noção de um contínuo em fluxo ou de um movimento livre. Esse porvir pode ainda pulsar, acolher e expulsar outro pensamento, outra política.

Uma dança (se) chega aí, vem como atraso e desvio parasitário, fraco, demandante de corpo, demandante do outro-outro, anunciando a insegurança e a fragilidade de sua borda. Sua vinda não vem direto; vem como desviante, gagueja, incorpora muitos outros num mesmo espaço-tempo disjuntivo; vem numa textualidade atravessada por técnicas, aparatos e heranças que a precedem e que também estão por vir. Espectrologia assombradora. Precisa parar para tomar fôlego, menstrua, sente dor e ainda pode provocar lágrimas - em quem vê e no que é visto, seja humano ou animal, ou onde esse enfrentamento é posto em crise. 
Cansa, toma fôlego - tem que respirar, hospedar o ar-outro que invade sem licença. Essa é uma lei incondicional do corpo que dança (para o desespero de alguns): é preciso parar, repetidamente. Essa é a única certeza do trabalho em dança. $\mathrm{O}$ corpo cansa, cai, tem peso... cede à gravidade incondicionalmente no seu pe(n)sar. E aí está o limite entre o saltar de um prédio e o cair de um prédio ${ }^{412}$, entre um Yves Klein e os anônimos que caem do World Trace Center sobre nossas cabeças [cujos nomes nunca saberemos precisamente, mas ainda assim eles perturbam a nossa memória da experiência de estar com dissidentemente]. L'atopie et/ou la folie que não nos oferece nenhum horizonte.

$\mathrm{Na}$ travessia que nos trouxe até aqui, insistimos nessa força fraca de pensar uma dança porvir como incondicionalidade sem soberania, no espaço teatral e fora dele. Uma cena de pensamento que vem dançando sem horizonte. Dessa partida, caberia agora repetir, de outra maneira, um problema que venho anunciando desde as primeiras linhas desta tese: podem citações, enxertos, anedotas e todas as figuras parasitológicas do discurso que assombram na queda das pálpebras encetar e compor uma dança, sem necessariamente defender uma lei, um originário teleológico ou campo próprio de sentido para a dança? $\mathrm{Ou}$ ainda: [Enxertando o problema da telecomunicação ${ }^{413}$ que já pensamos de muitas maneiras e que em nada nos autorizou por ela mesma e nela mesma, comunicar nada em si, podendo designar movimentos não semânticos desde a sua comunicação ${ }^{414}$ :] Seria assim possível por uma cena de dança "comunicar um movimento ou (...) um abalo, um choque, um deslocamento de força" "415, dançar sem dançar? Mesmo quando privado do espaço livre e de direito da dança, dançar como uma força fraca? Sim, sim — resposta que não define nenhum horizonte; eco responsivo que se demora nas heranças, espectrologias, economias, navegações e paragens da resposta bipartida que se dá ao outro. Fé por vir, fé sem garantias, chamada de/chamado à dança por vir — de partida.

O sim, sim que não pode comunicar nada sem se furtar a incalculáveis interrupções, interceptações, saltos, desvios, badernagens e subjetilidades não diz respeito a uma nova epistemologia para a dança. Trata-se de uma abertura ao

\footnotetext{
${ }^{412}$ Agradeço a Charles Feitosa, que, de alguma maneira, me ajudou a chegar a essa formulação numa de nossas conversas entre as ruas e os seminários que partilhamos juntos.

${ }^{413}$ Telecoreografia é um tipo de telecomunicação, poderíamos dizer.

${ }^{414}$ Ecos dos espectros de Derrida advindos de Assinatura Evento Contexto (1991).

${ }^{415}$ DERRIDA, 1991, p. 349.
} 
pensar e sua incondicional hospitalidade ao que e a quem vem como outro sem se deixar ver vir. Uma questão ético-política que pode inclusive resistir à publicidade da política, ao phainesthai (a fenomenalidade do fenômeno) do espaço público.

\footnotetext{
"Alguma coisa", que não é nem uma coisa nem uma causa, se apresenta no espaço público, mas ao mesmo tempo subtrai-se a ele, resiste a ele. Trata-se aí de um singular princípio de resistência ao político tal como ele é determinado desde Platão, desde o conceito grego de democracia até as Luzes. "Alguma coisa" aí resiste por si mesma sem que tenhamos que organizar uma resistência com partidos políticos. Isso resiste à politização, mas, como toda resistência a uma politização, é também naturalmente uma força de repolitização, um deslocamento do político. ${ }^{416}$
}

Sim, é preciso reconhecer os modos operatórios, os cálculos, as maquinarias e as evidências que assombram e dão ritmo aos modos de se pensar a dança. Mas é preciso também dizer sim, sim à vinda do que vem escapar aos cálculos, às teoréticas, aos visíveis sob a luz do evento que vem dançando e que pode dar-a-pensar outras danças, telecoreografar outros pensamentos.

Como responder aos pontos cegos, aos assombros, às memórias que vêm em ruínas e que, como forças fracas, nada nos afirmam soberanamente nem como coisas, nem como objetos, nem campos de circulação das danças? Como pensar o pôr em risco do télos em que nos afundamos para responder ao evento por vir quando diante das paragens provocadas por uma dança que vem às cegas? Acreditando no faro de outra política, nesse "alguma coisa" que nos diz Derrida como um deslocamento político por vir. Justamente no, right at/to right now, porvir desse evento, deve haver "alguma coisa" ainda por vir. Talvez essa seja uma crença racional e razoável, entre reor e ratio [que precisa de um exercício de tradução entre muitas línguas, como vimos com Derrida], com a qual podemos seguir pensando danças.

\section{2.}

Da Escuridão e dos Enceguecimentos em De Repente Fica Tudo Preto de Gente, de Marcelo Evelin

\footnotetext{
${ }^{416}$ DERRIDA, 2012, p. 88.
} 
Um último giro. Dessa vez com uma dança de Marcelo Evelin ${ }^{417}, D e$ Repente Tudo Fica Preto de Gente $(2012)^{418}$, para pensar a experiência de enceguecimento e da cegueira diante do seu horizonte sem horizonte. Utilizarei um tom de relato sobre a experiência com a obra, deslocando o sobre da noção de direção ao horizonte para o sobre como coinscrição da dança que se reelabora na experiência inscritiva. Performance de escrita com a obra aqui e lá.

Neste outro sobre, não se desenha nenhuma restituição de sentido a respeito da obra. Imprime-se já experiência quando depois de um sem horizonte. Evelin e Derrida se encontrarão, não por acaso, nesta escrita. Ambos de diferentes maneiras me conduziram ao estar com a dança sem horizonte.

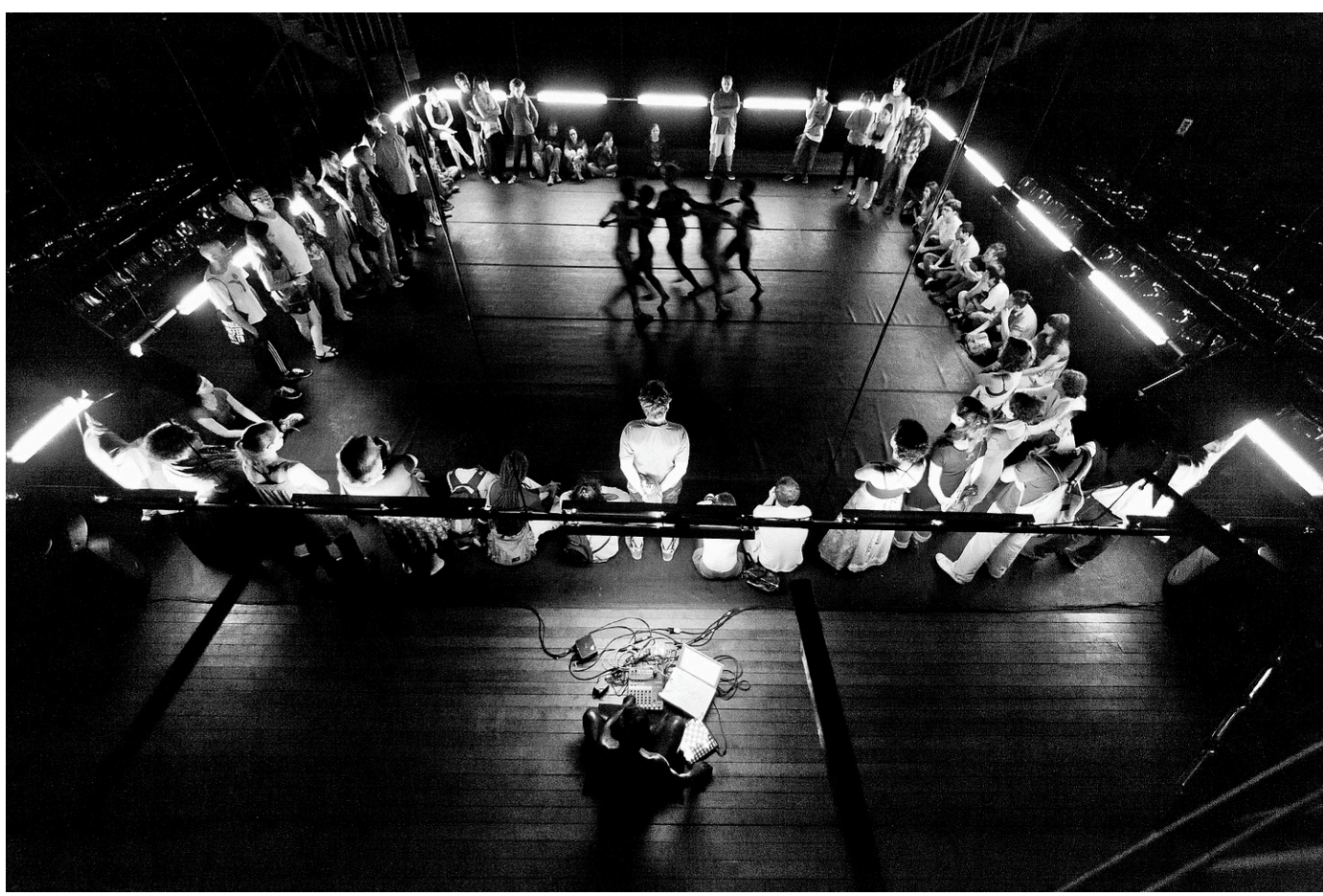

De Repente Fica Tudo Preto de Gente (2012) (1). Foto: Sérgio Caddah, 2012.

\footnotetext{
${ }^{417}$ Marcelo Evelin é coreógrafo, pesquisador e intérprete. Vive e trabalha entre Amsterdã e Teresina. É diretor e fundador do Demolition Inc. Site do artista: $<$ http://www.demolitionincorporada.com $>>$.

${ }^{418}$ Estreada em 2012, no Teatro Sérgio Porto, no Rio de Janeiro, durante o Festival Panorama. A obra reuniu artistas radicados em diferentes partes do mundo (Teresina, Kyoto, Amsterdã, Salvador, São Paulo e Ipatinga). Além da performance de estreia, tive a oportunidade de assistir a esse trabalho, uma segunda vez, no Teatro Gamboa (RJ), em setembro de 2013. Um vídeo com extratos do trabalho pode ser acessado neste link: $<<$ https://www. outube.com/watch?v=pAuEPD6oDCI $>>$.
} 
Ao chegar à sala do teatro, o público é convidado a entrar numa espécie de curral, delimitado por uns tubos de lâmpadas fluorescentes que formam um quadrado. Nenhuma outra luz no palco, tudo extremamente preto, escuro e por ali um amontoado de corpos besuntados de carvão, tão pretos ao ponto de quase não se poder distingui-los da escuridão. Na primeira experiência, talvez por se tratar de um público de festival de arte contemporânea, o convite à entrada no curral foi quase plenamente aceito. Já na segunda, pouquíssimas pessoas entenderam ou aceitaram a proposição. Nessa segunda vez, como o fiz na primeira, eu rapidamente entrei no curral e percebi que, naquele momento, somente outros amigos, também bailarinos e artistas, tinham entrado. Logo atrás de mim, havia uma senhora sentada no chão, fora dos limites do curral, que se incomodou imediatamente com a nossa posição, nos pedindo para sair dali porque ela não conseguiria ver o espetáculo. Um amigo bailarino que estava comigo, Tony Everton, tentou explicá-la que a proposta do trabalho era de que as pessoas entrassem no curral. Ela enfaticamente reafirmou: "sim, mas eu preciso ver"! Mesmo retrucando, dizendo que não havia nada para ver ali, resolvi me agachar a princípio, mas também sabia que logo, logo precisaria sair dali ${ }^{419}$. Tal chamada à razão - "eu preciso ver" - e a resposta que imediatamente dei - "não há nada para ver" - me parece dizer respeito ao enceguecimento e à cegueira apontados por Derrida (2010). Para discutir aqui esses dois conceitos, antes preciso telecoreografar as memórias, religando algumas ruínas de pensamento que ainda me assombram a distância desde o acontecimento com obra de Marcelo Evelin.

Voltemos ao curral ${ }^{420}$ : ali dentro, um amontoado de besuntados de pretocarvão. Esse monte de pretos se movia em aglomerado, mantinha certa marcha rítmica entre eles, que me remetia a uma dança quase-índio. Digo quase porque me parecia também não haver nenhuma citação indicativamente direta aos rituais indígenas. Sim, havia, talvez, um rastro que ecoava dessas outras danças, advindo das telecoreografias que guardava em mim, mas nada evidentemente restituía a herança cultural indígena. Rastrear tal herança ali, ter algum rastro de índio naquelas passadas, talvez responda mais à minha ansiedade de antecipar aquela

\footnotetext{
${ }^{419}$ Pretendo retomar a questão desse saber que se antecipa mais adiante. Aguardemos.

${ }^{420}$ Há quem diga que aquele espaço se assemelha a um ringue. Eu prefiro chamar de curral.
} 
experiência dando um lugar a ela. Ao mesmo tempo, a citação aqui (neste texto) e (se houve) ali (em De Repente Fica Tudo Preto de Gente) joga com o deslocamento incondicional que surge da composição de escrituras de danças: seguimos escrituras de danças perseguidos por outras danças. Somente nesse sentido que posso dizer que havia ali rastros de uma quase-dança-de-índios naqueles corpos em aglomerado, também como quase-índios ${ }^{421}$, ao passo que se deslocavam pelo curral, interpassando seus braços, atados pelas mãos.

Àqueles que estavam dentro do curral, tentando ver vir qualquer coisa que vinha na sua direção, só restava abrir passagem, antecipando, assim, uma proteção diante daquele que vem e poderia os sujar de pretume viscoso. O ver vir e a vinda eram também marcados por um erotismo dado pelos corpos semidesnudos, "vestidos" apenas de textura carvão-óleo. A erótica viscosa das passagens entre corpos, besuntados e não besuntados, criava uma atenção e uma tensão naqueles que observavam e conseguiam manter-se a distância (ou fora do curral ou ainda nas suas quinas, sempre antepostos à coisa pretume que vinha).

Num dado momento da dança entre corpos, aquando depois dos ajustes necessários da retina exposta à baixa luminosidade, "alguma coisa" já poderia ser premeditada: se eles vierem, abrimos a passagem e deixamo-los ir sem tocarmos no seu carvão-óleo. Nessa antecipação, a experiência parece dominada pela ativação da visão e pelo aparato óptico já redomesticado à baixa luz: já era possível, após os primeiros minutos naquele ambiente escuro, ver vir, de repente, tudo ficar preto de gente. Daí poder-se-ia dizer que nada mais precisa ser teorizado ou experimentado nesse trabalho, depois que se entende o lugar de ativação do jogo: quais partes estão dadas num horizonte e seus desígnios de sobrevivência que compõe uma certa paisagem penumbral diante do público. Eu

\footnotetext{
${ }^{421}$ Importa lembrar o rastro colonial que o termo índio evoca. No período da colonização, iniciado no século XVI, índio não só era o termo usado para se referir àqueles que habitavam a Índia, mas também se tornou uma modalidade identificatória que designava todo e qualquer outro alhures desconhecido. Índio marca aqueles tão de lá, além mar, tão longe do horizonte daqueles capazes de lhe dar um desígnio - capturando-os por um conceito - apontados diante e distantes de uma caravela: o muito lá, o outro. Esse outro é dado pela força de uma interpelação violenta do colocar-se diante de. O afirmar-se índio pode, ao revés, performatizar a radical irredutibilidade e imprevisibilidade do outro [ou uma subjetividade outra], sempre por vir, sem poder ser antecipado, desde sempre em fuga, mesmo quando passivo. Nesse sentido: sim, aqui reafirmarei, por um instante telegráfico, poder pensar aqueles corpos como quase-índios dançando uma quase-dançade-índio. Sobre uma noção de índio que dialoga com essa questão, $c f$. CASTRO, Eduardo Viveiros de. Os Involuntários da Pátria. 2016. Texto disponível em: <<http://provocadisparates.blogspot.com.br/2016/04/os-involuntarios-da-patria-eduardo.html >>, último acesso: 10 ago. 2016.
} 
mesmo, quando na segunda vez com a obra, já havia "visto" De Repente... anteriormente. A dança estaria aí totalmente calculada e dominada pela pré-visão que configura uma lógica de pensamento frente à dança, ao mesmo tempo préconfigurando e dando paisagem à dança? Não, se pensarmos nesse evento de encontro com as danças como um acontecimento.

Derrida, em Pensar em Não Ver (2012), nos sugere que encontros com obras de arte podem ser deslocados da noção de pré-visão, do face a face da visão, da predisposição do diante de, para uma experiência do acontecimento. Experiência (Erfahrung) no sentido que essa palavra tem não de uma relação com o presente, com o que está presente, como um aí diante de um ser, mas no sentido de "a viagem ou a travessia, o que quer dizer experimentar rumo a, através da ou desde a vinda do outro na heterogeneidade mais imprevisível; (...) uma viagem não programável, da viagem cuja cartografia não é desenhável, de uma viagem sem design, de uma viagem sem desígnio, sem meta e sem horizonte" ${ }^{\text {422 }}$. Tal experimentação recoloca a experiência como radical acontecimento

(...) disruptivo, inaugural, singular, na medida em que precisamente não o vemos vir. Um acontecimento que antecipamos, que vemos vir, que pré-vemos, não é um acontecimento: em todo caso, é um acontecimento, cuja acontecimentalidade é neutralizada, precisamente, amortecida, detida pela antecipação ${ }^{423}$.

Derrida, assim, nos faz pensar que, mesmo quando estamos diante uma obra e somos capazes de neutralizá-la pelo aparato óptico-cognitivo - medindo distâncias, organizando desígnios e ações — , há ainda uma acontecimentalidade ocasionada pelo evento por vir de uma obra, na sua injunção disjuntiva, que sempre escapa à apreensão e produz uma espacialidade atravessada pela alteridade disruptiva, inaugural e singular. Não vemos vir a obra, mas a obra se dá como um acontecimento. Esse acontecimento, por sua vez, não é de nenhuma exclusividade ao "ao vivo". A noção de "ao vivo" é apeladora à metafísica de um presente "que nos relaciona à apresentação do presente: algo se apresenta, temos a experiência disso" ${ }^{424}$. A experimentação da experiência é de outro tempo, ou melhor, é da

\footnotetext{
${ }^{422}$ DERRIDA, 2012, p. 80.

${ }^{423}$ Idem, p. 70.

${ }^{424}$ Idem, p. 79.
} 
manutenção do tempo como sempre outro, como porvir que não podemos prever nem antever. Se dá na experimentação de uma "passividade cega", nos diz Derrida (2010), como uma experimentação de exposição ao sem horizonte. De Repente Tudo Fica Preto de Gente, no seu pretume partilhado, reativa, mesmo sem pré-ver ${ }^{425}$, tal passividade cega quando encena a experiência/experimentação do jogo entre os corpos-carvão-óleo e os outros que se distanciam deles.

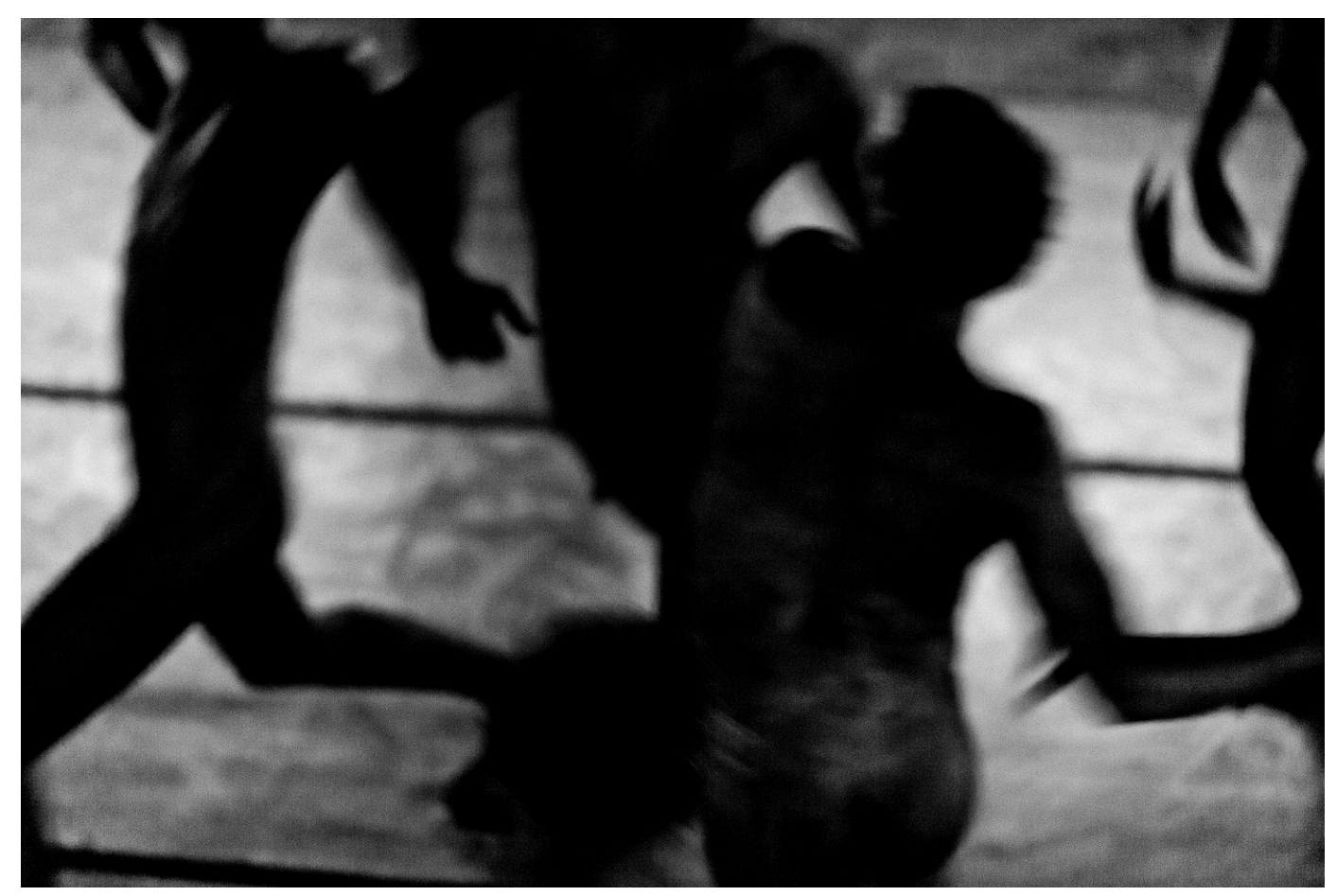

De Repente Fica Tudo Preto de Gente (2012) (2). Foto: Sérgio Caddah, 2012.

Os besuntados se abraçam e giram em bloco, numa força centrífuga desgovernada, avançando sem ver-a-onde no espaço, provocando uma imprevisibilidade maior no ritmo e na direção para onde rumam. Os não besuntados, a partir daí, não têm mais que abrir passagem, mas, sim, se safar do amontoado de carvão explosivo que avança intempestivamente pelo espaço. Sem direção, por vezes dispersos, aqueles outros que não querem se chocar com o pretume-viscoso têm como alternativas correr, desviar, tentar escapar e rir dos desencontros, dos tropeços, dos tombos pelo espaço. A imprecisão vem também dos cegos-pretos do outro lado: os bailarinos ou performers. Os pés de cada um se é que se pode dizer que aquelas coisas pretas ainda tinham pés tal como

\footnotetext{
${ }^{425}$ Digo isso mesmo não sendo a intenção de Marcelo Evelin e dos artistas envolvidos em $D e$ Repente... lançar tal problema como desígnio ou partitura conceitual de seu trabalho.
} 
dizemos certos de nossa hominidade: "eu tenho pés, distribuídos por calcanhar e cinco dedos que me aterram e me lançam" vasculhavam o espaço em vetores antagônicos, ao ponto de despencarem abruptamente ao solo nas vezes em que as dissidências nas negociações entre os bailarinos eram maiores que os acordos entre as forças de seus movimentos.

Alguns não besuntados chegam a sair de dentro do curral, pois nada aparentemente os impedia de ficar olhando a distância. Eu mesmo, quando experimentei a primeira vez De Repente..., em 2012, saí por alguns instantes porque estava com o tornozelo recém-torcido, mas, mesmo olhando a distância, De Repente Tudo Fica Preto de Gente conseguia propor uma arquitetura que me convidava mais a entrar do que continuar fora do curral. Entre tropeços, correrias, calmarias, o se sujar de carvão e o observar a distância a cena, criando alguma estratégia imediata para sobreviver, estávamos lá compondo aquela dança. O pretume, então, passa a não ser mais exclusivo àqueles que estão besuntados de carvão. Nessa outra disposição, ficar preto de gente ganha outra força que se dá na errância dupla dos corpos que seguem tateando o espaço tal como um cego desenhado por Antoine Coypel, em $O$ Erro, como uma lei assim pensada por Derrida em Memórias de um Cego (2010):

\begin{abstract}
Vendados, os olhos não estão naturalmente, mas pela mão do outro, ou pela sua, obedecendo a uma lei que não é natural ou física, uma vez que o nó, por detrás da cabeça, permanece ao alcance do sujeito que poderia desfazê-lo: como se o sujeito do erro consentisse naquilo que assim the venda os olhos, como se ele fruísse com o seu sofrimento e a sua errância, como se a escolhesse, no risco da queda, como se brincasse a procurar o outro no decurso de um sublime e mortal jogo da cabra-cega. ${ }^{426}$
\end{abstract}

[Esse corpo cego de Coypel parece se lançar à cegueira, como uma atividade voluntária, como quem jogasse "no risco da queda, como [se] brincasse a procurar o outro". Esse corpo cego era performado, na obra de Evelin, por aqueles que mesmo podendo sair do curral preferiam "ficar preto de gente", jogando com a vinda do pretume perigoso.]

É preciso notar a singularidade desse lançar-se ao jogo da cabra-cega, que não é ter a cegueira em si. Derrida falará dessa diferença comentando como a

${ }^{426}$ DERRIDA, 2010, p. 20. 
noção de cegueira na metafísica ocidental sempre foi tomada como uma violação do que se chama Natureza. A figura do cego sofre da marca, desde as mitologias - como pecado, falta, erro - de uma transgressão à vontade da Natureza. Derrida escreve que a associação entre erro e cegueira marcada por Descartes era afirmada como o erro do primeiro lugar da crença, uma opinião demasiadamente apressada, uma "falta de juízo, não da percepção, [que] trai o excesso da vontade infinita em relação ao entendimento finito" ${ }^{427}$. Com Derrida, pode-se dizer que, para Descartes, o erro-cegueira precisava ser corrigido, devolvendo a vista aos cegos e, ao mesmo tempo, fabricando óculos e mais sofisticados aparatos técnicos e também metafísicos para os que, mesmo não acometidos por cegueira natural [e que, sim, por algum desvio retínico ou de falta de ajuste óptico, optam por querer não ver], pudessem ter maior nitidez sobre a verdade. Porém, para Derrida, o não querer saber dos olhos afirma o sentido de uma destinerrância em que "estou no erro, engano-me porque, capaz de mover a minha vontade ao infinito e no próprio instante, posso querer ir para além da percepção, querer além do ver”428.

A obra de Marcelo Evelin faz tudo, de repente, ficar preto quando tal enceguecimento-errante passa a determinar a espacialidade da dança dançada com o outro. Tudo de repente vira carvão-óleo-combustão. Carvão-óleo-combustão ${ }^{429}$ entre corpos cegos vem sem ser visto, obliquamente, não por uma condição natural ou acidental de um aparato do olhar, pois, com a regulagem necessária de uma retina, já se pode antever um certo pretume que vem na visão. Mas no enceguecimento do tatear sem ver e do experimentar as passagens entre-tato dos corpos viscosos, todos são convidados a cegar-se enquanto dançam De Repente Fica Tudo Preto de Gente. Experimentar essa obra, encontrar-se com ela, demanda um certo não querer saber dos olhos, "aceitando, portanto, o jogo sem fim da alteridade, (...) não como resignação, e sim um modo afirmador" ${ }^{430}$. Esta não visão é ao mesmo tempo acompanhada por um tatear sem rumo, das mãos, dos pés e outras quinas que se ouriçam tanto na fuga quanto na vinda-preta desgovernadas. Carvão-óleo-combustão.

\footnotetext{
${ }^{427}$ Idem.

${ }^{428}$ Idem.

${ }^{429}$ O carvão-óleo-combustão de De Repente... era feito da mistura entre carvão e óleos vegetais, que não são o mesmo que um carvão-combustível extraído de reservas de carvão mineral. Mas, em De Repente..., no vibrátil e no atrito entre os corpos dançantes, besuntados e não besuntados, a mistura também emanava calor e destruição.

${ }^{430}$ DUQUE-ESTRADA, 2012, p. 14.
} 
O acontecimento ocasionado nessa desgovernança dupla não se dá pela visão, pela clarificação antecipatória da visão. O amontoado preto não vem ao encontro de meu horizonte, não posso premeditar a sua chegada a todo tempo. Tal como acontecimento, não vemos a obra vir, ou seja, a dança não se dá diante de mim, mas ela vem.

A impossibilidade de se estabelecer um horizonte para o que vem marca uma espacialidade da obra como uma arquitetura inencontrável. Não há fundo para o qual possa me distanciar e calcular em perspectiva: se sentar no chão, já estarei grudado no visco do carvão-óleo; se pular para fora do curral, já não poderei experimentar o não-ver e assim já estarei num certo pretume, numa certa penumbra de cegueira e, assim, já haverá algum encontro-cego com De Repente..., mas de uma potência muito amortecida.

A "passividade cega" de De Repente... evoca uma saída do conforto da contemplação. É preciso lançar-se à alteridade do jogo cego por vir. E nesse "é preciso" se enceta outro gesto para além do colocar-se diante para ver: tem que ainda tatear ativando a pele à exposição. A pele exposta reúne e redobra um certo aglomerado de corpo e também marca um abismo em relação ao outro. Pelebrisura que ao mesmo tempo aproxima, permite o enquadramento e reunião de um certo corpo, mas que também oferece resistência e distância ao outro. Ao se experimentar o acontecimento de De Repente..., desloca-se o pensar-ver para o pensar-tocar, perfazendo outra espacialidade e outra corporeidade.

O horizonte é o campo de possibilidade, o limite, que se dá diante de nós. É possível ler, apreender, esquematizar o que se aproxima diante de nós. Porém há sempre "alguma coisa" que não se anuncia no visível do espaço público. Há sempre outro que não se encerra na adequação cognitiva, no cálculo e reconhecimento do esquema "eu vejo aqui diante de mim" essa coisa "pretume" que se chama, ou melhor, que anuncia que "de repente tudo fica(rá) preto de gente" [estarei eu forçando a futuridade do ficar? Esse fica(rá) preto, "a coisa ficará preta", poderia deixar escapar um pretume por vir? Quando se diz preto, quando se pinta a si mesmo de preto, de carvão-óleo, dos pés à cabeça e também os cabelos, o que se anuncia sem ver vindo daí? O preto possível, no horizonte, ou o preto por vir de repente? Na dança de um preto para outro, entre besuntados e não besuntados, tudo fica ou ficará preto?] 
Em De Repente..., não há como direcionar-me nem como capturar o outro pretume plenamente pela visão, apontá-lo no curral, pois a escuridão desorienta. Além de correr da massa preta que vem, tenho ainda que negociar com os outros pretos que correm na multidão e que também vêm ao meu encontro, eu vou até eles. Há uma tatilidade que responde ao estar ali compondo: estar em De Repente Fica Tudo Preto de Gente é necessariamente estar-com disjuntivamente às cegas. Mesmo que eu não o veja, o outro vem! É preciso negociar/tatear

as proximidades e distâncias, desde o visgo do carvãoóleo escorregadio que sobrepõe a camada do chão: rastros da mistura de suor e carvão deixados pelos besuntados no solo que colam na sola de nossos sapatos. Sim, já estamos todos pretos com

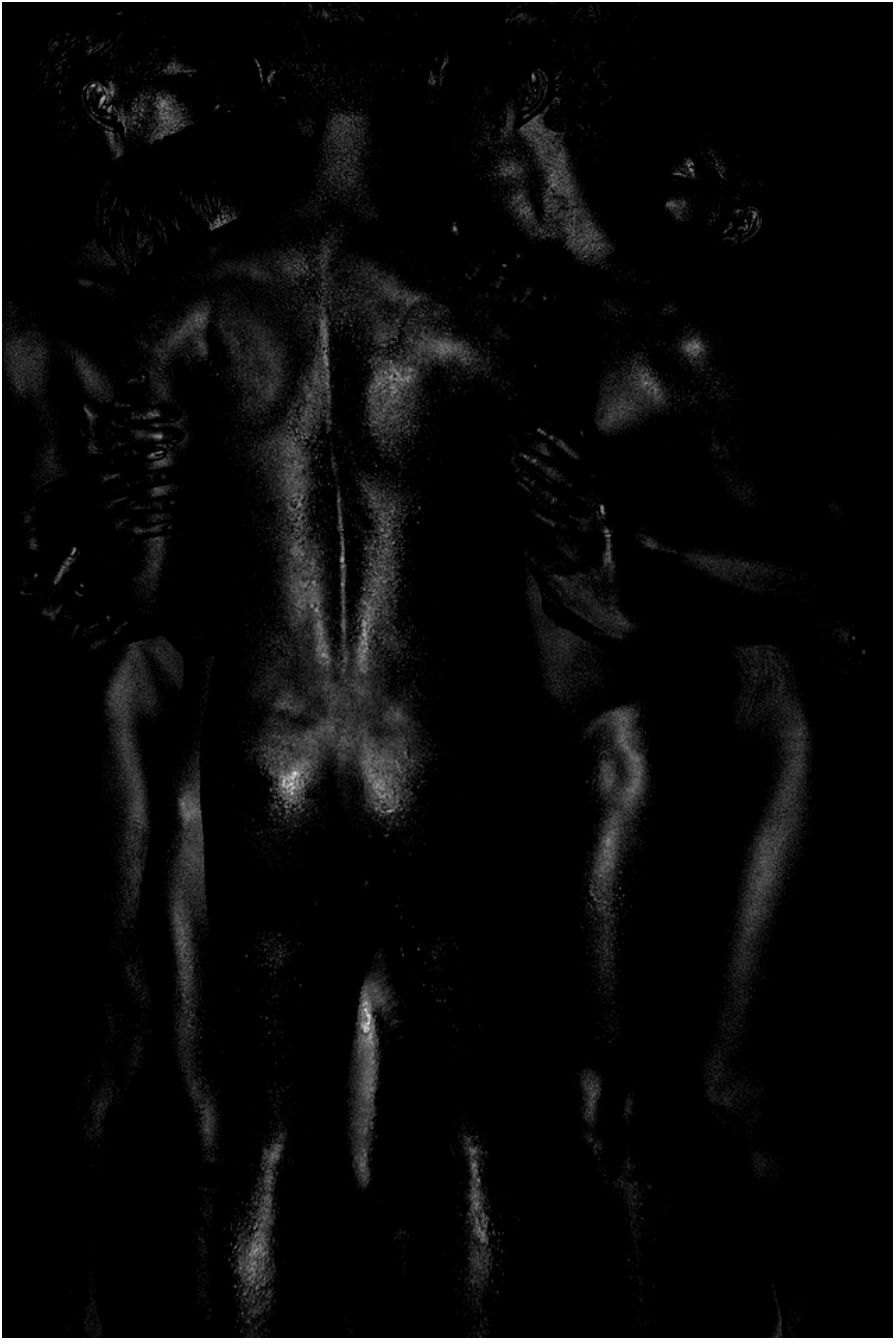
De Repente Fica Tudo Preto de Gente (2012) (3). Foto: Sergio Caddah, 2012. pretos, desde os pés.

Nos momentos em que a massa de besuntados tropeça e cai no chão, uma calmaria se coloca no curral. Os não besuntados, assim, se aproximam da coisa preta caída, recuperando o fôlego. O preto da pele besuntada de carvão-óleo parece agora o mesmo preto do chão do linóleo com visgo dos rastros pretos deixados; são como o piso. Piso preto. Ela, a coisa preta a se recuperar, agora parece quieta, parece deixar aproximar-se oferecendo alguma segurança aos olhares curiosos que se esticam para ver, analisar, domar mesmo que por instantes aqueles pretos. Antes de permitir-se domesticar, a coisa se levanta de novo, 
avança desgovernadamente no espaço e cai outra vez, repetidamente, criando um jogo de ir e deixar vir. Entre quedas e corridas, o pretume-carvão para. Levantamse agora múltiplas coisas, separadas, independentes, uma para cada lado. Executam gestos mínimos que parecem atrair outra vez os videntes.

Ainda um pouco desconfiado, me aproximo de alguns delas e vejo seus gestos, olho-os nos olhos e pareço sentir alguma confiança ou conforto outra vez. Posso me aproximar. Mas eis que, inesperadamente, outra coisa-preta-besuntada me assusta pelo lado e por trás, me fazendo trocar de posição. Observo outro e depois sou acometido pela vinda de outro e de outro:

\section{[...punhos de boxe;}

... esquiva tortuosa, escorregando e deslizando pelo piso;

... garota japonesa colhendo alguma coisa no chão;

... homem babando, olhando fixamente nos olhos;

... mulher balançando os braços como se acolhesse alguma coisa (para frente e para trás), coluna semicurvada e joelhos semiflexionados]

"Eles vêm sem eu ver". Chegam-me por todos os cantos sem que eu possa me antecipar, tal como as memórias e os rastros de uma ruína de pensamento que tento remontar agora nestas linhas. O preto vem! Se reúne outra vez - e eu já não sei se a cronologia ou a ordem dos acontecimentos foi exatamente essa, talvez não, certamente não - e inicia uma comilança erótica entre corpos. O carvão-óleo agora ganha sexo, no cio: deliciosos, pretos, ofegantes, sedentos, cheios de mãos escorregando entre as dobras, caçando os encontros entre peitos, bocas, buracos e membros.

A pretitude explode! Vira uma pancadaria entre besuntados. Os outros pretos fogem do curral, se acuam nos cantos, se escondem da violência diante dos olhos. Eles não fingem que batem: eles podem bater, te atravessar, te acertar como um martelo. Combustão disruptiva nas faíscas entre corpos-carvão-óleo. Cegos, sem ver, avançam no espaço afastando todos que restam. Abre-se, assim, um 
buraco negro, um vulcão de escuridão $o^{431}$ que aparta as partes no espaço. Os não besuntados foram praticamente expulsos e condicionados à distância.

De perto ou de longe, o não discernimento de para onde olhar, para quem olhar, para onde sair dali tornava-se cada vez mais singular. Mesmo fora, olhando de fora do curral, não ficava tão claro quem agia e quem testemunhava a ação, pois a saída do curral era também uma ação que redimensionava o acontecimento em composição no curral. O pretume já vermelho e alaranjado quase cheirava a sangue e seguia explodindo o espaço cada vez mais vazio.

Aglutinam o que restou de preto num canto qualquer. Os besuntados ficam um pouco ali, ainda juntos e frenéticos, passando de uma posição para outra... diminuem o ritmo e vão se separando lentamente, aproximando-se das beiradas do curral, agora todas lotadas. Olham para os que já estavam na beirada - não sei se eles realmente olhavam ou se fui eu que os vi olhar. Os videntes e visíveis atravessam a barreira das luzes fluorescentes, passando pelos corpos que ali se acuavam à beira da luz. Se afastam, está acabado.

De Repente Tudo Fica Preto de Gente não me conta nenhuma história, nem mesmo uma história do fim, mas me exigiu exercitar a experimentação de um fim que eu quase não podia ver. Exigiu, como uma máquina de lei, uma experiência de fim como acontecimento para compor aquele ambiente sem horizonte. Ninguém me dizia claramente o que fazer, para onde correr, e às vezes eu corria para um lado e esbarrava em outro. Outras vezes não corria, ficava olhando de longe, sem jamais ver um todo, e me sentia convidado a voltar para dentro do curral, me aproximar mais e escapar outras vezes. Não havia como estar rendido, porque a obra me colocava em risco e me dava, assim, um certo alívio

\footnotetext{
${ }^{431}$ Devo essa imagem-palavra à amiga Maria Alice Poppe. Não somente essa imagem, mas parte da atenção por que fui acometido sobre o "ver", devo ao encontro que tive com Maria Alice. Já estava lendo sobre o pensar em não ver e o enceguecimento em Derrida, mas as conversas e todas as dobraduras táteis que se desencadearam a partir de nossos encontros desviaram-me às cegas por outras errâncias no exercício de pensamento. Alice ainda não conhecia Derrida, quando nos conhecemos. Ela havia recebido uma indicação de Tadeu Capistrano para pesquisar algo sobre o subjétil pensado por Derrida e assim nos conhecemos. Apresentei ela algumas referências que usei na minha dissertação de mestrado sobre o subjétil e desde então, temos compartilhado pensamentos advindos do sim, sim da desconstrução.
} 
perturbador de lançar-me ao risco. Está aí performada a passividade cega sem redenção.

O estar entre corpos besuntados e não besuntados de carvão-óleo, compondo De Repente Tudo Fica Preto de Gente, não me dizia nenhuma narrativa, nenhum pré-roteiro diante de mim. Ao mesmo tempo, tal experiência de acontecimento me fez ter que dar fim a algumas decisões, para acolher muitas outras as quais eu não decidi nem ninguém objetivamente decidiu enquanto dançávamos no pretume lá e também enquanto dançamos aqui na brancura do espaçamento textual. Lá e aqui, há escuridão e fugitividade.

Essa dança na escuridão, em vez de nos colocar rendidos, arrebatandonos por visões de um mundo horizontal, enceta uma falência na dupla domesticação dos que testemunham e ao mesmo tempo atuam num acontecimento. Já num quando depois não sabemos bem o limite do público, da obra e do artista; já num quando depois "não sabemos bem" (nem na ordem de um subjetivismo nem na ordem de um objetivismo). Nessa espera sem salvação de um quando, De Repente... nos diz dançando: é preciso fazer tremer a dupla domesticação do esclarecimento e da promessa de esclarecimento quando já lançados na experiência/experimentação de um acontecimento.

Pensar a composição disjuntiva de De Repente Fica Tudo Preto de Gente nos põe na difícil tarefa incalculável da tradução e da participação quando já lançados na escuridão. De Repente... nos diz que, sim, há cálculo: as escolhas da obra de Evelin e Demolition Inc são, certamente, as evidências do cálculo; as escolhas que tive de fazer para sobreviver dançando sem ver em De Repente... e as telecoreografias que escrevi aqui são também rastros de cálculos. No entanto, todos esses cálculos encenam os incalculáveis ajustes entre-cálculos que mudam lugares. Esses incalculáveis, por sua vez, abrem-se a pensar aquando "de repente", já e quando depois de um acontecimento que vem dançando; pensar aquando do já e do quando depois da força de um "de repente" sem horizonte que não podemos antever nem nos proteger. 


\section{Considerações Finais}

As contribuições advindas desta tese atravessam os campos da filosofia, da dança e da performance, exorbitando suas disciplinas. O sim ao pensar requerido pela democracia por vir da desconstrução de Jacques Derrida escapa a qualquer constrição reguladora. Há, porém, alguma espacialidade que margeia a ocorrência desse pensar. Como escrevi na segunda seção desta tese, a abertura do sim — o sim, sim - ao pensar seria como a de uma hospitalidade da khora que "sem pertencer àquilo a que dá lugar, nada dando e nada dando de outro, ela [a khora] daria lugar ${ }^{\$ 432}$. Um outro espaço de direito, de política e de ética por vir, "ainda heterogêneo e rebelde, irredutível ao direito, ao poder, à economia da redenção"433. O sim, sim ao pensar não se rende nem ao campo da dança, nem ao campo da performance, nem ao campo da filosofia.

No entanto, não podemos partir para o fim desta escrita sem reiterar uma declaração marcada preliminarmente: "Esta é uma tese de doutorado em filosofia”. Ela foi escrita já se arquivando e já participando de uma certa experiência de filosofia, no Departamento de Filosofia da PUC-Rio, portanto já partindo de uma certa consignação e repetição que esse chamado, "filosofia", imprime. Todavia, tal declaração, ao mesmo tempo que promete e cumpre um certo protocolo de um doutorado em filosofia, abre-se à sua expatriação quando lançada ao porvir de sua textualidade. Ela [a tese] está aberta à chegada do outro ao tornar-se pública, sem que isso signifique sair do secreto para o não secreto. $\mathrm{Ou}$ seja, mesmo na experiência de sua leitura integral, esta tese demanda suplementaridade, conjura falta e necessidade como o porvir de sua marcha. Esse foi um dos temas abordados aqui, e, portanto, as críticas e as observações advindas da leitura e do ritual de defesa desta tese engendram o seu movimento iterável de abertura ao sim, sim à chegada do outro. Nesse sentido, os desdobramentos do debate aquando depois de sua publicização são, de partida, já acolhidos pela própria incalculabilidade que o apelo desta escrita reivindica. Uma

\footnotetext{
${ }^{432}$ DERRIDA, 2009c, p. 36.

${ }^{433}$ Idem.
} 
hiperética do direito ao direito de resposta, já estando na filosofia, já estando com a dança e a performance; para além da filosofia, da dança e da performance.

É preciso dizer sim, sim à vinda do outro.

Esse "é preciso..." assombrou esta escrita entre cenas e obscenas disjuntivas. A proposição da noção de telecoreografia nos ajudou a pensar, com os rastros da dança, as forças de teletransportação, tradução e iterabilidade de gestos, coreografias, textos, chamados e rastros de rastros que põem o pensamento em cena já apagando os rastros de sua obscena. Os episódios do espectro-Carmen ${ }^{434} \mathrm{e}$ a conversa telemática com Côté $^{435}$ foram algumas das primeiras aberturas para se pensar as implicações ético-políticas que obsidiam os espaços de circulação e pressuposição institucional do pensamento. O primeiro episódio, mais próximo da instituição filosófica; o segundo episódio, mais próximo da instituição artística.

Como vimos com Derrida (2002; 2009b), a estrutura sacrificial de qualquer instituição demanda hospitalidade do outro [ora como hospedeiro, ora como hóspede, ora como hostil] para delimitar suas leis de autodeterminação e formas de partilha, bem como para dar acesso às suas leis e formas de partilha. Porém Derrida também nos ajudou a pensar como na mesma estrutura sacrificial escapa uma brecha autoimunitária de sua unidade reguladora como pressuposição institucional: "Na ordem de identificar a si mesmo, de ser o que é, delimitar a si e reconhecer a si em seu próprio nome, ela deve defender os próprios contornos de seu adversário (...). Ela deve usar as marcas de seu adversário, até mesmo ter seu nome como marca negativa [na cavidade de seu arquivo]"436. Em nome de sua soberania, as instituições de pensamento estão expostas e abertas ao outro.

No entanto, pensar as telecoreografias de incorporação/excorporação do outro, tal como fizemos ao longo desta tese, não restitui nenhum originário nem a natureza de um evento sacrificial. Tal gesto nos conduz à reflexão sobre a alteridade radical que obscenamente denegamos em nome do poder de autodeterminação de qualquer ipseidade: seja das instituições, dos sujeitos, da leis, da memória, das formas de partilha ou de qualquer $U m$ supostamente

\footnotetext{
${ }^{434}$ Vide segunda seção.

${ }^{435}$ Vide terceira seção.

${ }^{436}$ DERRIDA, 2002, p. 5. [Grifos do autor; comentários meus].
} 
indivisível. Telecoreografias nos convocam a pensar na força de um il faut como se diz na língua do outro, ao mesmo tempo, como "o que é preciso" e "o que falta" para uma hiperpolítica e uma hiperética. "Cálculo incalculável”, diria Derrida (2009b), que é preciso pensar para uma desconstrução irredutível.

Telecoreografia, ainda, é um pensamento de estado de dívida incalculável advinda das perseguições de múltiplos espectros ${ }^{437}$. A sua formulação está diretamente endividada com a herança arquival (como consignação, divisibilidade e partilha) das danças de Lepecki (2006) e Arbeau (1995) e dos espectros de seus tempos. Está também endividada com os rastros de outros espectros de Derrida (1994), Marx (2010; 2013), Shakespeare (2005) e seus suplementos. Rastros de rastros que se autoapagam quando começam a delirar atopicamente entre assinaturas, giros, paragens, respiros, seções e saltos desta tese. Assim, é preciso afirmar o pensamento da telecoreografia como um exercício que não se encerra aqui nem instaura nenhuma epistemologia para um restrito domínio de saber. Ele não reivindica nem pode reivindicar propriedade para si. Qualquer investimento nesse pensamento demanda um gesto expatriado e ao mesmo tempo local. Nesta tese, telecoreografia não poderia ser efetivamente pensada se não fosse tensionada entre tantos suplementos. A sua abertura aos processos variados de incorporação/excorporação é, portanto, de partida a brecha autoimunitária de sua desconstrução por vir. Até mesmo sua sutil e ficcional distância em relação à noção de coreografia já marca a exposição de sua fragilidade suplementar do telecoreográfico $^{438}$.

\footnotetext{
${ }^{437}$ Uma hauntology para usar um termo pensado por Derrida (1994).

${ }^{438}$ Especialmente sobre a noção de coreografia pensada por Lepecki, é importante reafirmar que ela não difere integralmente da minha proposição de telecoreografia. Coreografia é um tipo de telecoreografia e vice-versa. Uma pode se prometer para a outra. A sutil diferença entre uma noção e outra está apenas marcada na reafirmação iterável da distância que evoca o radical tele. A noção de coreografia se imprime como um processo de repetição iterável da distância de uma dança. E Lepecki sabia disso quando escreveu sobre a impossibilidade de a escrita coreográfica restituir qualquer rastro fundacional de uma dança sem vacilar: a sua Dis-tanz. O autor afirma: "ela [a escrita coreográfica] torna o corpo do dançarino um veículo para o meio de uma transação temporal; ela cura o dilema um pouco embaraçoso da dança de sempre perder-se assim que performada. Com o diálogo homossocial retratado no livro de Arbeau, essa função dupla de escrita modela a dança como indisciplinada, frívola [light-headed], escorregadia [slippery] - que são os mesmos atributos negativos de que a feminidade é acusada. Não obstante, a Orquesographie de Arbeau (literalmente, a escrita do movimento) ainda demonstra a confiança em uma simetria semiótica entre escrita e dança que garante o não problemático tráfico de um para o outro. Essa confiança, porém, não iria durar muito tempo (LEPECKI, 2004, p. 126, comentários do autor, grifos meus). Coreografias, nas suas danças indisciplinares, são telecoreográficas. A minha insistência na telecoreografia é para marcar de forma mais radical o problema da tradução e do "tráfico de um para o outro" mesmo quando se faz a promessa de restituição de um movimento primeiro originário. É também para abrir a telecoreografia como um pensamento exorbitante da
} 
As múltiplas passagens de tons desta tese foram também uma telecoreografia de difícil modulação. Em alguns momentos, foi necessário seguir um faro específico para abrir margens a discussões que nos levariam a outros faros, chegando até o precipício de uma encalhagem. O giro por Bruno Latour (2010; 2013) e, em seguida, o pequeno entre-salto com Jacques Rancière (2008) foram momentos em que a inflexão telecoreográfica talvez tenha nos levado a caminhos aparentemente irresolúveis. Porém essas passagens foram construídas como uma estratégia importante para se pensar os limites éticos e políticos que margeiam o problema da reunião, seja de um certo nós existencial ou dos nós necessários nos quais temos que insistir para continuar pensando as hipóteses abissais em que decidimos nos encalhar.

Especialmente, a passagem por Latour nos oportunizou pensar a urgência do fim de algumas hipóteses sobre o modo de estar-com que compõe forças na experiência social contemporânea. As questões trazidas pelo autor sobre as noções de Antropoceno e Gaia, em Waiting For Gaia (2010) e Facing Gaia (2013), construíram pontes para se pensar os limites éticos das conjunções entre arte, política e ciências. Meu argumento tomou a proposição de Latour como problemática ao tomar a arte como ferramenta (ainda que profilática e ficcional) de redenção diante do porvir da catástrofe. Latour, especificamente em Waiting For Gaia, considera a arte uma ferramenta política no processo de reconstrução de uma moral coletiva capaz de reintegrar a experiência do nós-em-Gaia. Rancière (2008), por sua vez, foi chamado ao debate para dar uma resposta à limitação dessa proposição que subjuga o político da arte a uma noção de engajamento esclarecido pela experiência estética. Rancière nos ajudou a reposicionar $o$ político das artes como partilha do dissenso, e, nesse sentido, o apelo de reconciliação moral de Latour sofreu um abalo. Tal discussão foi essencial para o que eu pretendia desenvolver mais adiante sobre a baderna na pólis contemporânea. Porém, como vimos, Rancière desenvolve seu argumento, de alguma maneira, encerrando diálogos com a herança de Marx e seus espectros.

Da minha parte, então, foi necessário marcar uma distância em relação a um certo eco pejorativo que o nome de Marx tem evocado no debate político nos últimos anos. Desconfio que Rancière não tem a pretensão de fazer coro ao que se 
"mostrificou" como "antimarxismo" e suas consequências arbitrárias e incongruentes, como o Movimento Escola sem Partido, no Brasil. Contudo, sabendo que telecoreografias podem ser compostas mesmo que à revelia do querer-dizer-do-autor-e-sua-intenção, precisei marcar um gesto de distância meu em relação aos espectros que rondam contemporaneamente em torno deste maldito nome que se chama Marx.

É preciso ler Marx! $!^{439}$ - ecoei de volta.

Este "é preciso..." (como um il faut) singular nos lançou para o trabalho sobre Marx para além de um certo marxismo, porém jamais antimarxismo, jamais antimarxista. O é preciso ler Marx, aqui, conjurou Derrida, Marx e a dança. Minha contribuição pontual na leitura irredutível de Marx com Derrida foi tangenciada pelo uso da palavra dança pelos dois autores, uso em geral negligenciado nas leituras contemporâneas de Espectros de Marx (1994).

A reflexão sobre o uso da dança por Marx e Derrida criou aberturas para pensar questões do estar-com disjuntivo no rastro do espectro dançante, nos levando a refletir sobre o fator econômico circular que se engendra "tão irredutível quanto reinscrito no texto social - mesmo este sendo apagado, embora de maneira imperfeita"440. A iterabilidade do "siga-me, guarde-me, adeus" advindo do evento de uma dança espectral reposicionou o debate tradicional das noções de arquivo ${ }^{441}$ e suas implicações nos estudos da dança e da performance. Nesse novo debate, o Jamais se Renuncia ao Arquivo (2010), de Duque Estrada, construiu um solo importante para focar nas questões de turbulência, divisibilidade e sofrimento do Mal de Arquivo ${ }^{42}$, abrindo margens para seguirmos pensando telecoreografias da memória e das heranças da dança primeiramente com Finita (2013), de Denise Stutz, e, logo em seguida, com a chamada da baderna e a chamada à baderna.

\footnotetext{
${ }^{439}$ Tarefa em que sou ainda um iniciante, confesso; mas repito essas palavras também para mim mesmo, me lançando ao desafio por vir de pensar outras telecoreografias entre Marx, Derrida e questões pertinentes à dança e à performance como desdobramentos futuros desta pesquisa.

${ }^{440}$ SPIVAK, 2010, p. 60.

${ }^{441}$ Como vimos com a discussão que teci com Diana Taylor (2013), Peggy Phelan (1997) e Paulo Cesar Duque Estrada (2010).

${ }^{442}$ DERRIDA, 2001a.
} 
A iterabilidade da baderna, desde o seu nome, arquiva e anarquiva danças e dissidências como radicais suplementaridades, nos convocando a repensar como fazemos política no estar-com-disjuntivo da pólis contemporânea. Telecoreografando a discussão da baderna com a discussão de Derrida sobre as interpelações de rogue e voyous, problematizei outra vez o poder de reunião de forças na pólis contemporânea e seu rastro dançante, irremediável e indomável, incapaz de constituir um nós de um éthos coletivo sem produzir violência.

Nesse giro, partimos para uma tensão produzida pelo pensamento de Butler (2015) a respeito da violência ética do $e u$ que pode dizer um "ei, tu, baderneiro!". Com a discussão da despossessão do eu de Butler, pudemos pensar como a interpelação de um “tu, baderneiro!" na ipseidade de uma língua só é possível se incorporando o tu como parte do eu que o interpela. Qualquer um que interpele um tu como baderneiro — como um "ei, tu, baderneiro!" — o faz somente acolhendo o outro em si, na sua despossessão de si, ou seja, já encena a baderna em seu si despossuído. Quem diz “tu, baderneiro!” performa a baderna incorporando-a na sua linguagem; performa a baderna como sujeito capaz de dizer “eu, tu e nós” na mesma ipseidade da língua.

Chegamos à sexta seção refletindo sobre os desafios éticos e políticos do pensar a filosofia e pensar a dança a partir de uma hipótese abissal lançada por Derrida (2009b) sobre a impossível ${ }^{443}$ tarefa de "salvar a honra da razão". Em $O$ “Mundo" das Luzes Por Vir (2009), Derrida nos ofereceu uma leitura perspicaz sobre a tarefa enlutada de seguir acreditando na dignidade da razão sem jamais se render à razão do $U m$ de qualquer entidade reconciliadora e autorregulatória. Seu pensamento de hipótese abissal que vem por baixo como um acontecimento que não se dá no horizonte, aquando nem mãos nem braços podem mais nos salvar, nos possibilitou saltar para a problematização da teorização em dança por vir.

Nessa discussão, retomei algumas questões lançadas por Derrida em Pensar em Não Ver (2012), as quais o filósofo franco-argelino problematiza a noção de theorein, predominante no exercício da teorização profundamente marcado pelo haptocentrismo: habilidade entre mãos e olhos da prática teorética de tocar o outro sem tocar, prevendo a sua vinda desde o horizonte. Derrida, em

\footnotetext{
${ }^{443}$ A noção de impossibilidade na desconstrução, não esqueçamos, é um convite à inventividade do sim ao pensar sem horizonte.
} 
seu texto, nos convidou a pensar em não ver como um gesto de desconstrução do teórico tradicional, desde o corpo e a carne que trabalha essa prática ${ }^{444}$.

Minha contribuição nesse debate adveio da arqui-pedagogia-teorética em que estou fundado, não somente por estar teorizando nesta tese, mas sobretudo por eu ser professor de um curso de Teoria da Dança. Meu lugar de fala sobre a desconstrução da noção de teoria não poderia obliterar essa encalhação/encalhamento autobiográfica em que, com alguma inabilidade, já me demoro há alguns anos. Por esse motivo, parti para a tarefa de enlutamento da teoria da dança, começando pela escavação dos arquivos que se guardam sobre o nome teoria. Soçobrando no rastro de theorein pensado por Derrida, escavei outras impressões - theoria, theorós, theatrón, teomai - que recolocaram a divisibilidade da noção de teoria para além do cálculo que se dá no horizonte visível e à disposição das mãos e olhos do sujeito teórico.

Theatrón e teomai, mesmo reservando alguma relação com o visível (o lugar em que se-dá-a-ver e o que se dá-a-ver, respectivamente), apontam o desafio da teatralidade de toda teoria, que demanda o tornar-se público ao entrar em cena, ao circular como cena, portanto guardando uma invocação de radical alteridade na exposição ao outro. Theoria, como reunião em torno de um telos, por sua vez, reimprime em teoria a questão da consignação do arquivo e seu chamamento à partilha e à divisibilidade da herança, tal como pensado por Derrida sobre o princípio arcôntico do Mal de Arquivo (2001): reúnem-se teorias já como forma consignável, divisível e partilhável, portanto desconstrutível na cavidade do seu próprio arquivo. Por fim, theorós - o embaixador viajante que substitui o olho do rei a distância - reacende um debate sobre a noção de teoria como uma tarefa sempre errante de envio e como tarefa inábil: qualquer noção, conceito, objeto em si, para si não se constrói sem mediação com o outro. Os olhos do soberano, em toda teoria, governam a distância na partilha com o outro. O theorós é a

\footnotetext{
${ }^{444}$ A noção de trabalho, escrita e gesto filosófico e sua relação com o corpo atravessaram várias seções desta tese. Permitam-me recapitular, ainda que elipticamente, algumas delas com o leitor: as incorporações/excorporações telemáticas de Carmen e Côté (seções 2 e 3); a questão do corpo bem formado no ensinamento coreográfico de Arbeau (seção 2) e a inflexão para um pensamento de corpus político bem formado, no cruzamento entre Latour e Artaud (seção 4); a hierarquia linear manovisual da escrita e sua solidariedade técnica, econômica e ideológica (seção 3); a questão da materialidade do trabalho em Marx, em $O$ Capital, que se confunde com as próprias mãos e o trabalho do filósofo sobre a mesa, pensado a partir de Espectros de Marx, de Derrida (seção 5); as metáforas de encalhação e encalhamento pensadas por Derrida e o corpo inábil quando na experiência sem horizonte (seção 6).
} 
embaixada e o medium sem os quais não praticamos nenhum theorein: brecha autoimunitária para a desconstrução de teorias que convida a escavações, viagens, errâncias, navegações e paragens que circunscrevem as práticas teóricas. Numa última elipse, afirmaria que as múltiplas telecoreografias entre theorein, theoria, theorós, teomai, theatrón reposicionam a teoria como experiência/experimento desde o seu corpo-palavra como acontecimento sempre por vir.

Incalculabilidade do cálculo, razão por vir. Sim, sim, outra vez!

A recolocação da questão ético-política da teorização por vir contribui significativamente para a tarefa de pensar e teorizar Derrida para além de Derrida. Também, como na estratégia singular que tracei aqui, põe a discussão da teorização em dança para além de impressões equivocadas de movimento de livre circulação. A esse respeito, refleti sobre o habitual discurso de se pensar a dança imediatamente como movimento. Refleti sobre essa tradução direta-direita que não se pergunta sobre as violências que se reencenam com-a-dança e contra-adança em nome do fluxo contínuo de movimento. A dança para ${ }^{445}$, precisa tomar fôlego. A dança para na frente de mesas e portas, também.

Os movimentos de paragens na dança precisam ser pensados, sobretudo aqueles que em nome da autodeterminação do vir-a-ser-movimento reencenam a estrutura sacrificial na dança. Dança arquiva impressões históricas, por vezes repressivas e supressivas, que recalcam outras danças, interditando a chegada do outro por direitos e ritmos bem marcados, bem singulares. A palavra dança, diferentemente de movimento, reserva alguma arqui-história singular inscrita no seu corpo, na sua reunião de experiências e de movimentos distintos, alguns incorporados por uma certa tradição e outros não.

Acreditando na fé exorbitante e sem garantias do seguir teorizando danças, encerrei a penúltima seção desta tese refletindo com a obra de Marcelo Evelin e Demolition Inc De Repente Fica Tudo Preto de Gente (2012), sobre a experiência/experimento de pensamento ao estar com uma dança na escuridão sem horizonte. A minha leitura não reserva nenhuma exclusividade à $D e$ Repente... No entanto, a singularidade dessa obra nos possibilitou pensar a

\footnotetext{
${ }^{445}$ Ecos de Lepecki (2006), outra vez.
} 
questão da incalculabilidade do cálculo aquando da vinda do outro que vem sem se deixar ver vir.

Para outros estudos de Derrida, Quando um Pensamento Vem Dançando, Quando a Soberania Treme deixa um convite para pesquisadores, comentadores e tradutores da obra do filósofo franco-argelino: o desafio de se pensar outras telecoreografias da desconstrução com as artes. Também apresenta um percurso que precisa ainda ser desdobrado sobre a discussão da democracia por vir de Jacques Derrida, atentando para o cruzamento entre Who's Afraid Of Philosophy (2002) e Vadios (2009), em que a democracia por vir é pensada como razão por vir e como evento por vir desde a pressuposição institucional da filosofia. Ainda, para o campo dos estudos da dança e da performance, esta tese contribui com o debate de questões entre arte, filosofia e política, convidando outros artistas, professores e pesquisadores a pensar o porvir de suas práticas. O meu percurso, por sua vez, já aponta alguns desdobramentos que seguirei desenvolvendo em pesquisas futuras.

Por fim, uma questão de estilo precisa ser reiterada. Ao longo de toda esta tese, invoquei muitos nomes para denunciar nas entrelinhas dessa narrativa telecoreográfica que não há pensamento desconstrutivo sem a chegada do outro. Muitas formulações desta tese advieram dos encontros na vida institucional e na vida não institucional. Os poucos nomes que citei ao longo desta tese são apenas alguns rastros dos acolhimentos e envios que me fizeram sair do discurso monotônico. Estado de dívida performado para repercutir o tremor desde a língua, o timbre e a modulação advinda do outro. Mais de um.

...Carmen,

Clarice,

Eduardo, André, André, Stock, Lepecki, Thoinot, Iara, Tonlin, Paulo, Lúcia, Lídia, Anita, Denise, Marcial,

Diana, Abigail, Carla, Dani, Tony, Alyne, Jacques, Derrida, 
Ángeles, Cesar,

Karl, Judith,

Butler, Judite,

Araújo, Herbet,

Aline, Raema,

Sérgio, Andrea,

Juliana,

Mariana, Zeza,

Marie, Jean,

Antonio, Antonin, Artaud,

Fernanda,

Maira, Marcus,

Olivia, Marcelo,

Evelin, Bruno,

Latour, Tadeu,

Alice, Alice,

Serra, Poppe,

POP, Charles,

Feitosa, Camillo,

Gayatri, Luisa,

Marieta,

Baderna,

baderna...

\section{[...] Quando a soberania treme.}

Disse treme... E quem/que treme? Alguém treme, algum treme, o um treme. Promessa de abalo da unicidade do $U m$, sobretudo de um certo tipo de autodeterminação do $U m$ que se esquece de sua abertura e exposição à alteridade. Fazer tremer. Mais de um. Basta de somente um. Resistir ao esquematismo logocêntrico não é um capricho teorético. O compromisso aqui é outro, sobretudo um compromisso por vir tríptico, de pancada e lance, que já disse antes e, ainda, $e$ preciso, na necessidade e na falta desse gesto, continuar a dizer: evento por vir, democracia por vir, razão por vir. E, se não for exigir demais do leitor, peço que o repita novamente com uma pequena diferença: evento por vir democracia por vir razão por vir.

Já de partida (e) quando depois. 


\section{8 \\ Referências bibliográficas}

AGAMBEN, Giorgio. O Que É o Contemporâneo? e outro ensaios. Tradução de Vinícius Nicastro Honesko. Chapecó: Argos, 2009.

AHMED, Sara. Orientations Matter. In: COOLE and FROST (ed.). New Materialism: ontology, agency and politics. Durham \& London: Duke University Press, 2010, pp. 233-257.

ANDERS, Günther. Le Temps de la Fin. Paris: L’herne, 2007.

ANDRADE, Sérgio Pereira. O Grupo CoMteMpu's e a Dança Frouxa: (re)olhares sobre o pensar-fazer desconstrutivo em Dança. Dissertação de Mestrado - Programa de Pós-Graduação em Artes Cênicas, Universidade Federal da Bahia, 2010.

Sobre a Subjetilidade Fora de Si. Sapere Aude - Revista de Filosofia, Belo Horizonte, v. 4, n. 7, p. 79-113, jul. 2013a. ISSN 2177-6342. Disponível em: $<$ http://periodicos.pucminas.br/index.php/SapereAude/article/view/5530/5519>. Acesso em: 28 jun. 2016.

Traição em Desconstrução: sobre a tradução, o subjétil, a dança e além. Dissertação de Mestrado - Departamento de Filosofia, Pontifícia Universidade Católica do Rio de Janeiro, 2013b.

ARBEAU, Thoinot. Orchesography: 16th-Centeury French Dance from Court to Countryside. New York: Dover Publications, Inc., 1995.

ARTAUD, Antonin. O Teatro e Seu Duplo. São Paulo: Martins Fontes, 2006.

AUSTIN, John Langshaw. Quando o Dizer É Fazer - palavras e ação. Tradução de Danilo Marcondes de Souza Filho. Porto Alegre: Artes Médicas, 1990.

BARDET, Marie. A Filosofia da Dança - um encontro entre dança e filosofia. São Paulo: Martins Fontes, 2014. 
BENINGTON, Geoffrey. A Besta e o Soberano: Três Notas Para Derrida. Alea, Rio de Janeiro, vol. 17/1, p. 35-51, jan-jun. 2015.

. Política e Amizade: uma discussão com Jacques Derrida. In: DUQUEESTRADA, Paulo Cesar (org.). Desconstrução e Ética: ecos de Jacques Derrida. Rio de Janeiro: PUC-Rio; São Paulo: Loyola, 2004.

BENJAMIN, Walter. A Tarefa do Tradutor. Tradução de Fernando Camacho. Belo Horizonte: UFMG, 2008.

BHABHA, Homi. O Local da Cultura. Belo Horizonte: UFMG, 2007.

BLESSING, J. Revenant Images: Memory's trace in postwar art. IN: GUGGENHEIM Museum. Haunted: contemporary photography, video, performance. New York, 2011, pp. 14-49.

BOURCIER, Paul. História da Dança no Ocidente. São Paulo: Martins Fontes, 2006.

BUTLER, Judith. Bodies in Alliance and the Politics of the Street. Eipcp. Disponível em: http://www.eipcp.net/transversal/1011/butler/en. Último acesso: 16 ago. 2016.

. Relatar a Si Mesmo - crítica da violência ética. Belo Horizonte:

Autêntica, 2015.

CASTRO, Eduardo Viveiros de. Os Involuntários da Pátria. 2016. Texto disponível em: <<http://provocadisparates.blogspot.com.br/2016/04/osinvoluntarios-da-patria-eduardo.html $>>$, último acesso: 10 ago. 2016.

CAUQUELIN, Anne. Teorias da Arte. Tradução de Rejane Janowitzer. São Paulo: Martins Fontes, 2005.

CORVISIERI, Silverio. Maria Baderna: a bailarina de dois mundos. Tradução de Eliana Aguiar. Rio de Janeiro/São Paulo: Editora, 2001.

DAWKINS, Richard. O Gene Egoísta. São Paulo: Edusp, 1979. 
DE REPENTE FICA TUDO PRETO DE GENTE. Espetáculo de Dança. Coreografia: Marcelo Evelin. 60min. Rio de Janeiro, 2012.

DEBORD, Guy. A Sociedade do Espetáculo. Comentários Sobre a Sociedade do Espetáculo. Tradução de Estela dos Santos Abreu. Rio de Janeiro: Contraponto, 1997.

DERRIDA, Jacques. A Escritura e a Diferença. Tradução de Maria Beatriz Marques Nizza da Silva, Pedro Leite Lopes e Pérola de Carvalho. São Paulo: Perspectiva, 2009a.

Assinatura Acontecimento Contexto. In: Margens da Filosofia.

Tradução de Joaquim Torres Costa e Antônio M. Magalhães. São Paulo: Papirus, 1991a, pp. 349-373.

Du Droit a la Philosophie. Paris : Galilée, 1990.

Eating Well or the Calculation of the Subject. In: CONNOR, NANCY and CADAVA (Editors). Who Comes After the Subject? New York: Routledge, 1991b. Unesp, 1998.

Enlouquecer o Subjétil. São Paulo: Ateliê Editorial; Fundação Editora

Espectros de Marx - o estado de dívida. Rio de Janeiro: RelumeDumará, 1994.

Esporas: os estilos de Nietzsche. Tradução de Rafael Haddock-Lobo e Carla Rodrigues. Rio de Janeiro: NAU, 2013.

Given Time: I. Counterfeit Money. Translated by Peggy Kmuf. Chicago and London: The University of Chicago Press, 1991c.

. Glass. Milão: Bompiani, 2006.

1973.

. Gramatologia. São Paulo: Perspectiva; Universidade de São Paulo, 
. Limited Inc. São Paulo: Papirus, 1991d.

. Mal de Arquivo - Uma impressão freudiana. Tradução de Cláudia Morais Rego. Rio de Janeiro: Relume Dumará, 2001a.

. Memórias de um Cego: o autorretrato e outras ruínas. Tradução de Fernanda Bernardo. Lisboa: Fundação Calouste Gulbenkian, 2010.

2007.

O Cartão-postal: de Sócrates a Freud. São Paulo: Civilização Brasileira,

. O Monoliguismo do Outro: ou a prótese de origem. Tradução de Fernanda Bernardo. Porto: Campo das Letras, $2001 \mathrm{~b}$.

Papel Máquina. Tradução de Evandro Nascimento. São Paulo: Estação Liberdade, 2004.

Pensar em Não Ver: escritos sobre as artes do visível (1979-2004). Organização de Ginette Michaud, Joana Masó e Javier Bassas. Tradução de Marcelo Marques Moraes. Florianópolis: UFSC, 2012.

Points de Suspension. Paris: Galilée, 1992.

Posições. Jacques Derrida. Tradução de Tomaz Tadeu da Silva. São Paulo: Autêntica, 2001b.

2002.

. Torres de Babel. Tradução de Junia Barreto. Belo Horizonte: UFMG,

. The Beast \& The Sovereign. Translated by Geoffrey Bennington. Vol 1. Chicago and London: The University of Chicago Press, 2009b.

. Vadios. Tradução de Fernanda Bernardo. Coimbra: Palimage, 2009c.

Who's Afraid of Philosophy? Right to Philosophy I. California:

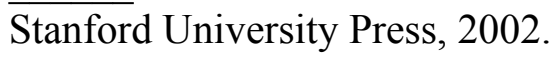


DUQUE-ESTRADA, Paulo Cesar (org.). Às Margens: a propósito de Derrida. Rio de Janeiro: PUC-Rio; Loyola, 2002.

Jamais se renuncia ao Arquivo Notas sobre 'Mal de Arquivo' de Jacques

Derrida. Nat. hum., São Paulo, v. 12, n. 2, p. 1-16, 2010. Disponível em

$<$ http://pepsic.bvsalud.org/scielo.php? script $=$ sci_arttext\&pid $=$ S151724302010000

$200002 \& \operatorname{lng}=$ pt\&nrm=iso $>$. Acesso em 06 ago. 2016.

Derrida: O Pensamento da Desconstrução Diante da Obra de Arte. IN:

LOBO, Rafael Haddock. Os Filósofos e a Arte. Rio de Janeiro: Rocco, 2010, pp333-344.

. Desconstrução e Ética: ecos de Jacques Derrida. Rio de Janeiro: PUCRio; Loyola, 2004.

Dos Olhos e das Mãos: arte e "deixar ser" em Heidegger e Derrida. IN:

BARTHOLOMEU, Cezar (org.). Deslocamento Friç̧ão: Galpão Capanema. Rio de Janeiro: Escola de Belas Artes, 2012, pp. 8-19.

Espectros de Derrida. Rio de Janeiro: PUC-Rio; Loyola, 2008.

FINITA. Espetáculo de Dança. Coreografia: Denise Stutz. 45min. Rio de Janeiro, 2013.

FOUCAULT, Michel. Microfísica do Poder. Tradução de Roberto Machado. Rio de Janeiro e São Paulo: Paz \& Terra, 2015.

FRANKO, Mark. Writing Dancing, 1573. In: Dance as Text: Ideologies of baroque body. Cambridge University Press, 1993.

FREUD, Sigmund. Luto e Melancolia. In: Obras Completas de Sigmund Freud vol. XIV. Rio de Janeiro: Imago, 1920.

HADDOCK-LOBO, Rafael. Uma Brisura: Derrida às margens de Nietzsche. Morpheus - Revista de Ciências Humanas. Disponível em:

$<$ http://www.unirio.br/morpheusonline/>. Acesso em 15 ago. 2016. 
HEIDEGGER, Martin. Ensaios e Conferências. Tradução de Emmanuel Carneiro Leão, Gilvan Fogel e Márcia Sá Cavalcante Schuback. Petrópolis: Vozes; Bragança Paulista: Editora Universitária São Francisco, 2008.

. Já Só Um Deus Pode Ainda nos Salvar. Tradução de Irene Borges Duarte. Covilhã: LusoSofia Press, 2009.

Ser e Tempo. Vol. 2. Petrópolis: Vozes, 1997.

Sobre o Humanismo ou Carta Sobre o Humanismo. Tradução de Emanuel Carneiro Leão. Rio de Janeiro: Tempo Brasileiro, 1967.

HOBBES, Thomas. Leviatã. São Paulo: Martins Fontes, 2003.

KANT, Immanuel. Crítica da Faculdade do Juízo. Tradução de Valério Rohden e António Marques. Rio de Janeiro: Forense Universitária, 1993.

A Metafísica dos Costumes. Tradução, textos adicionais e notas de Edson Bini. Bauru: EDIPRO, 2003.

LATOUR, Bruno. Facing Gaia - Six lectures on the political theology of nature. Disponível em: <http://www.bruno-latour.fr/>. Acesso em 20 abr. 2013.

Wainting for Gaia. Composing the common world through arts and politics. Disponível em: <http://www.bruno-latour.fr/>. Acesso em 20 jun. 2013.

LIDDEL, H. G. \& SCOTT, R. Greek-English Lexicon. Oxford: Clarendon Press, 1940.

LIMA, Daniella; AURÉLIO, Mariana; SOTER, Silvia (org.). Gesto: práticas e discursos. Rio de Janeiro: Cobogó, 2013.

LEPECKI, André. Coreopolítica e Coreopolícia. Ilha. v. 13, n. 1, p. 41-60, jan./jun. (2011) 2012.

Exhausting Dance - performance and the politics of movement. New York: Routledge, 2006. 
O Corpo Colonizado. Gesto, Revista do Centro Coreográfico do Rio de Janeiro: RioArte, 2003.

LEPECKI, André (ed.). Of The Presence Of The Body - essays on dance and performance theory. Middletown: Wesleyan University Press, 2004.

LEPECKI, André; JOY, Jenn (ed.). Planes of Composition: dance, theory and the global. New York: Seagull Books, 2009.

LOUPPE, Laurence (ed.). Imperfections in the Paper. In: Traces of Dance drawings and notations of choreographers. Paris: Editions Dir Voir, 1994.

MARX, Karl; ENGELS, Friedrich. Manifesto Comunista. São Paulo: Boitempo Editorial, 2010.

MARX, Karl. O Capital. Livro I. São Paulo: Boitempo Editorial, 2013.

MATTHES, Maíra. A Soberania Fraca. Revista Direito e Práxis, vol. 3, n. 5, 2012, pp. 138-152.

NIETZSCHE, Friedrich. Vérité et mensonge au sens extra-moral. Paris: Actes Sud, 2002.

RANCIÈRE, Jacques. A Partilha do Sensível: estética e política. Tradução de Mônica Costa Netto. São Paulo: 34, 2009.

RANCIÈRE, Jacques. The Misadventures of Universality. IN: Daniel Birnbaum; S.O. Wallenstein; J. Buckstein (Orgs). Thinking Worlds. Sternberg Press, NY, 2008.

SCHMITT, Carl. Political Theory - four chapters on the conceept of sovereignty. Chicago: University of Chicago Press, 2005.

SILVA, Eliana Rodrigues. Dança e Pós-Modernidade. Salvador: Edufba, 2005.

SHAKESPEARE, William. Hamlet. Tradução de Elvio Funck. São Leopoldo: Unisinos, 2005. 
SPIVAK, Gayatri Chakravorty. Pode o Subalterno Falar? Belo Horizonte: UFMG, 2014.

Translator's Preface. In: DERRIDA, J. Of Gramatology. Translation: Gayatri Chakravorty Spivak. Baltimore: The Johns Hopkins University Press, 1997.

TAYLOR, Diana. O Arquivo e o Repertório: performance e memória cultural nas Américas. Tradução de Eliana Lourenço Lima Reis. Belo Horizonte: UFMG, 2013. 